\author{
UNIVERSIDADE DE SÃO PAULO \\ INSTITUTO DE ESTUDOS BRASILEIROS \\ PROGRAMA DE PÓS-GRADUAÇÃO \\ CULTURAS E IDENTIDADES BRASILEIRAS
}

SYLVIA DE LEON CHALREO: A EDITORA DA ESFERA

Ana Lúcia Vasconcellos Queiroz.

(Versão corrigida)

São Paulo

2019 


\author{
UNIVERSIDADE DE SÃO PAULO \\ INSTITUTO DE ESTUDOS BRASILEIROS \\ PROGRAMA DE PÓS-GRADUAÇÃO \\ CULTURAS E IDENTIDADES BRASILEIRAS
}

\title{
SYLVIA DE LEON CHALREO: A EDITORA DA ESFERA
}

\section{Versão Corrigida}

(A versão original encontra-se na unidade que aloja o programa de pós-graduação)

Ana Lúcia Vasconcellos Queiroz.

Dissertação apresentada ao Programa de Pós-Graduação Culturas e Identidades Brasileiras do Instituto de Estudos Brasileiros da Universidade de São Paulo, para a obtenção do título de Mestre em Filosofia.

Área de concentração: Estudos Brasileiros

Orientadora: Prof ${ }^{\mathrm{a}}$. Dr ${ }^{\mathrm{a} .}$ Flávia Camargo Toni

São Paulo 
DADOS DE CATALOGAÇÃO NA PUBLICAÇÃO (CIP)

Serviço de Biblioteca e Documentação do

Instituto de Estudos Brasileiros da Universidade de São Paulo

(c) reprodução total

Q3

Queiroz, Ana Lúcia Vasconcellos

Sylvia de Leon Chalreo : a editora da Esfera - São Paulo, SP / Ana Lúcia Vasconcellos Queiroz ; Flávia Camargo Toni, orientadora -- São Paulo, 2019.

Dissertação (Mestrado) - Universidade de São Paulo. Instituto de Estudos Brasileiros. Programa de Pós-Graduação em Culturas e Identidades Brasileiras. Área de concentração: Estudos Brasileiros. Linha de pesquisa: Brasil : a realidade da criação, a criação da realidade.

Título em inglês: Sylvia de Leon Chalreo : the publisher of Esfera - São Paulo, SP.

Descritores: 1. Chalreo, Sylvia de Leon, 1905-1991 2. Partido Comunista do Brasil 3. Arquivos pessoais 4. Arte social 5. Literatura social 6. Periódicos I. Universidade de São Paulo. Instituto de Estudos Brasileiros. Programa de Pós-Graduação II. Toni, Flávia Camargo, orient. III. Título. 


\section{Folha de Aprovação de Mestrado}

Nome: Ana Lúcia Vasconcellos Queiroz

Título: Sylvia de Leon Chalreo: a editora da Esfera.

Dissertação apresentada ao Programa de Pós-Graduação Culturas e Identidades Brasileiras do Instituto de Estudos Brasileiros da Universidade de São Paulo, para a obtenção do título de Mestre em Filosofia.

Aprovado em: 02/09/2019

Banca Examinadora

Orientador: Prof. Dra. Flávia Toni

Instituição: Assinatura:

Profa. Dra.:Ana Paula Simioni Instituição: IEB/USP

Julgamento: Assinatura:

Profa. Dra. Heloisa Faria Cruz Instituição: PUC/SP

Julgamento: Assinatura:

Prof. Dr.:Giovana Deliberali Maimone Instituição: ECA/USP Julgamento: Assinatura: 


\section{DEDICATÓRIA}

À memória de Alcina de Oliveira Toledo, Florinda da Conceição Fontes, Lucy Costard Queiroz, Luzia Xavier, Maria Aparecida Toledo Vasconcellos, Maria Cecília Vasconcellos Coelho, Maria Olímpia Costard de Carvalho e Sylvia de Leon Chalreo. 


\section{AGRADECIMENTOS}

Agradeço sobretudo a minha orientadora, Flávia Toni, a Amabeny Xavier Zoet, detentora do acervo de Sylvia de Leon Chalreo e aos meus pais, Maria Salete Vasconcellos Queiroz e Alberto Costard Queiroz (in memorian).

Aos colegas, professores e funcionários do IEB e FFLCH, que me deram suporte nesta trajetória.

A Prof. Tânia Garcia, pela contribuição desde a elaboração do projeto inicial.

Ao meu afilhado Lucas Borgomoni, pela cuidadosa tradução do resumo deste trabalho.

A Renata Zoet e Ana Agostini, pelo apoio e confiança.

A Jacques Ardies e Ana Maria Magalhães, por seus depoimentos.

E com todo carinho e muita alegria, aos familiares amigos, porque sem amor nada acontece:

Pedro Queiroz Bruschi, Maria Laura Bertazzi, Ornella Flandoli, Marilene Fernandes Silva, Marta

Oliveira, Tiago José Costa, Marcelle Pride, Vera Piza, Ana Célia Rodrigues e, em especial, a Márcia Zoet. 
QUEIROZ, A. L. V. Sylvia de Leon Chalreo: a editora da Esfera [dissertação]. São Paulo: Instituto de Estudos Brasileiros, Universidade de São Paulo, 2019.

\section{RESUMO}

Durante o início década de 1930, Sylvia de Leon Chalreo (Rio de Janeiro, 1905 - 1991) foi feminista atuante, militante do Partido Comunista Brasileiro e jornalista. Em 1938, foi uma das fundadoras da revista Esfera, de Letras, Artes e Ciências (1938 - 1950), editada e distribuída com o apoio do PCB. A partir de 1940, concomitantemente ao trabalho jornalístico, abraçou a carreira de artista plástica, alcançando considerável prestígio. Seu arquivo pessoal, composto por documentos textuais, imagéticos e da cultura material ficou conservado no antigo apartamento onde faleceu, no Rio de Janeiro. Com o desenvolvimento da história cultural, das pesquisas qualitativas e da micro história o conhecimento da experiência do indivíduo em seu tempo e lugar se tornou fundamental para a interpretação dos processos sociais, o que fez com que os arquivos de pessoas passassem a ser valorizados como fonte de pesquisa pelos historiadores. Baseada em uma reflexão teórico metodológica sobre arquivos pessoais e biografia e se apoiando na metodologia desenvolvida por Howard Becker em Mundos da Arte, que compreende a obra de arte como resultado de uma ação coletiva, esta dissertação utiliza o arquivo pessoal de Sylvia de Leon Chalreo como fonte de pesquisa para a narração de fragmentos de sua trajetória de vida durante os anos 1930, .trazendo à tona a atuação de intelectuais feministas, artistas e escritores de diferentes regiões do país e do mundo, que expressavam a modernidade em suas obras e estavam unidos pela posição política antifascista.

Palavras-chave: Arquivo pessoal. Feminismo. Partido Comunista do Brasil. Arte Social. Literatura Social. 
QUEIROZ, A. L. V. Sylvia de Leon Chalreo: a editora da Esfera [dissertação]. São Paulo: Instituto de Estudos Brasileiros, Universidade de São Paulo, 2019.

\begin{abstract}
During the early 1930s, Sylvia de Leon Chalreo (Rio de Janeiro, 1905 - 1991) was an active feminist, a militant of the Brazilian Communist Party and a journalist. In 1938, with the help of PCB to edit and deliver, she co-founded Esfera magazine, a publication that dealt with subjects related to Languages, Arts and Sciences (1938 - 1950). From 1940, concomitantly to the journalistic work, she embraced the career of plastic artist, reaching considerable prestige. Her personal archive, composed of textual, imagery and material culture documents was preserved in the old apartment where she passed away in Rio de Janeiro.

With the development of cultural history, qualitative research and micro-history, the knowledge of one's experience in its time and place became fundamental for the interpretation of social processes, which made people's files valuable as a source of research by historians. Based on a theoretical methodological reflection on personal archives and biography and supported by the methodology developed by Howard Becker in Art Worlds, which comprises the work of art as a result of a collective action, this dissertation uses the personal archive of Sylvia de Leon Chalreo as a source of research for the narration of fragments of her life trajectory during the 1930s, drawing on the work of feminist intellectuals, artists and writers from different regions of the country and the world who expressed modernity in their works and were united by the anti-fascist political position.
\end{abstract}

Keywords: Personal archive. Feminism. Communist Party of Brazil. Social Art. Social Literature. 


\section{LISTA DE FIGURAS}

Figura 1 - Sylvia de Leon Chalreo, c. 1931. Fonte: Arquivo Silvia............................................. 14

Figura 2 - Apartamento onde Silvia morou de 1956 a 1991. Foto: 2016 ...................................... 15

Figura 3 - Apartamento onde Silvia morou de 1956 a 1991. Foto: 2016 ......................................... 16

Figura 4 - Silvia, Favela, 1946, 52 x 53,5 cm, óleo sobre tela. Coleção Particular .......................... 17

Figura 5 - Silvia, Fábrica de Vidro, 1944, óleo sobre tela. Coleção Particular................................ 17

Figura 6 - Silvia, Gente e casa, 1984, óleo sobre tela, 65,2 x $81 \mathrm{~cm}$. Coleção Masp - Museu de Arte de São Paulo Assis Chateaubriand

Figura 7- Silvia, Roda, 1950, óleo sobre tela, Coleção MAM, Rio de Janeiro, doação Miguel Paranhos do Rio Branco 18

Figura 8 - Silvia, Fantasias, 1983, óleo sobre tela, 46 x 38 cm, Coleção Museu Anatole Jakovsky 19 Figura 9 - Silvia, As Costureiras, 1959, óleo sobre tela, 48 x 60 cm, Coleção Galeria Jacques Ardies

Figura 10 - TABELA 1 - Arquivos de Mulheres em Instituições Culturais no Brasil (maio/2018).. 20

Figura 11 - Nísia Floresta, c. 1885. Fonte: Biblioteca Nacional, domínio público 40

Figura 12 - Flory Gama, Busto de Maria Firmina dos Reis, 1976. Fonte: ARRAES, 2017 40

Figura 13 - M. J. Garnier, Retrato de Narcisa Amália c. 50 anos de idade, 1906. Bico de pena. Fonte: FENSKE, 2015, domínio público

Figura 14 - Figura 13 - Retrato de Maria Benedita Câmara Bormann, c. 1899. Fonte: SABINO, [1899] 1996, domínio público

Figura 15 - J. Alves Leite, Luciana de Abreu, 1873. Litografia. Fonte: Wikimedia Commons, Museu Júlio de Castilhos, domínio público.

Figura 16 - Júlia Lopes de Almeida, 1903. Desenho da matéria de frente da primeira edição de Ância

Eterna. Fonte: Wikimedia Commons, domínio público 42

Figura 17 - Plateia do evento Hora da Arte, Athénée Clube, 1931. Fonte: Arquivo Silvia.............. 46

Figura 18 - Antonieta de Souza, c. 1930. Fonte: Revista da Semana, 27/09/1930 ........................ 47

Figura 19 - Á esquerda, Sylvia na inauguração do Athéne, 1931 .................................................49

Figura 20 - À direita, Sylvia de Leon Chalreo, c. 1931. ................................................................ 49

Figura 21 - Olga Praguer Coelho, 1943. Fonte:Wikimedia Commons, domínio público ...............50

Figura 22- Eugênia Álvaro Moreyra, c. 1929. Fotografia. Fonte: Diário de Notícias, 26/05/1929...52 
Figura 23 - Reprodução digital da capa da Revista Brasil Feminino, abril/1933. Fonte: Hemeroteca Digital Brasileira

Figura 24 - Reprodução da Coluna Proletária da Revista Brasil Feminino. Fonte: Revista Brasil feminino, fev./mar, 1933. Hemeroteca Digital Brasileira.

Figura 25- Reprodução da capa da Revista Esfera n 16, 1946. Ilustração de Tomás Santa Rosa. Fonte: Arquivo Silvia.....

Figura 26 - Maria Jacintha Trovão Campos. Fonte: Focus Portal Cultural

Figura 27 - Eneida de Moraes, c. 1929. Fotografia. Fonte: Fon Fon, 30/11/1929, 23. Hemeroteca Digital Brasileira.

Figura 28 - Nair Baptista, c. 1931. Fotografia. Fonte: Fon Fon, 28/11/1931, 25. Hemeroteca Digital Brasileira 64

Figura 29 - Maura de Senna Pereira, c. 1931. Fotografia. Fonte: Fon Fon, 28/11/1931. Hemeroteca Digital Brasileira.

Figura 30 - Autor desconhecido, Cinelândia, Rio de Janeiro, c. 1935. Fonte: Álbum do Rio de Janeiro,

BN Digital, domínio público. .70

Figura 31 - Carlos Scliar, Chinês, c. 1938. Desenho. Reproduzido na Esfera 8: 9. 87

Figura 32 - Percy Lau, sem título, c. 1938. Xilogravura. Reproduzida na Esfera 4, 17 .................87

Figura 33 - Luís Soares, Praia de Olinda, s/d. Aquarela. Reproduzida na Esfera 3:39 ................... 89

Figura 34- Gilda Moreira, A Negra, c. 1938. Óleo sobre tela. Reproduzido na Esfera 4: 39 .......... 90

Figura 35 - Oswald de Andrade Filho (Nonê), sem título, c. 1938. Reproduzido na Esfera 3: 7 ..... 92

Figura 36 - Paulo Werneck, Formas, c. 1938. Reproduzido na Esfera 1: 21 ............................. 92

Figura 37 - Abel Salazar, Mulher do Povo, sd. Desenho. Reproduzido na Esfera 1:25

Figura 38 - Leopoldo Mendez, sem título, c. 1938. Xilogravura. Reproduzida na Esfera, n. 2: 22101

Figura 39 - Frans Masereel. Sem título, c. 1938. Desenhos. Reproduzidos na Esfera 3:17 ............ 102

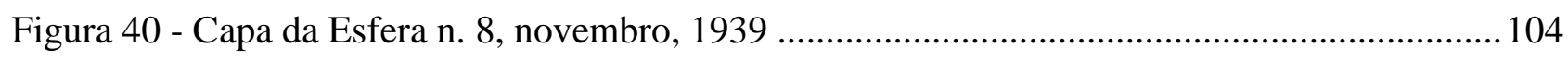

Figura 41 - Tabela 2 - Índice, Revista Esfera, de Letras, Artes e Ciências, Rio De Janeiro, 1938 1950 .

Figura 42 - Tabela 3 - Relação das Propagandas de Estabelecimentos Comerciais e Serviços, Esfera, Rio De Janeiro, 1938 - 1950.

Figura 43 - Tabela 4 - Relação de Propagandas de Livros, Periódicos, Livrarias e Editoras, Esfera, Rio de Janeiro, 1938 - 1950 143

Figura 44 - Tabela 5 - Relação de Propagandas de Empresas de Radiodifusão, Esfera,RJ, 1938...148 


\section{LISTA DE ABREVIATURAS}

\begin{tabular}{|c|c|}
\hline $\mathrm{ABI}$ & - Associação Brasileira de Imprensa \\
\hline $\mathrm{ABL}$ & - Academia Brasileira de Letras \\
\hline $\mathrm{ABM}$ & - Associação Brasileira de Música \\
\hline ANL & - Aliança Nacional Libertadora \\
\hline ANM & - Aliança Nacional de Mulheres \\
\hline CAM & - Clube dos Artistas Modernos \\
\hline CEB & - Casa do Estudante do Brasil \\
\hline DESPS & - Delegacia Especial de Segurança Política e Social \\
\hline ELFGCS & - Escritório de Ligação Feminina Geral e Ciências Sociais de Niterói \\
\hline ELP & - Empresa de Leitura e Publicidade Ltda. \\
\hline ENBA & - Escola Nacional de Belas Artes \\
\hline FBPF & - Federação Brasileira pelo Progresso Feminino \\
\hline FUNARTE & - Fundação Nacional das Artes \\
\hline GRAP & - Grupo Radical de Ação Popular \\
\hline IC & - Internacional Comunista \\
\hline IEB & - Instituto de Estudos Brasileiros \\
\hline INM & - Instituto Nacional de Música \\
\hline PCB & - Partido Comunista do Brasil \\
\hline SPHAN & - Serviço do Patrimônio Histórico e Artístico Nacional \\
\hline UERJ & - Universidade do Estado do Rio de Janeiro \\
\hline UFB & - União Feminina do Brasil \\
\hline UNE & - União Nacional dos Estudantes \\
\hline
\end{tabular}




\section{SUMÁRIO}

INTRODUÇÃ

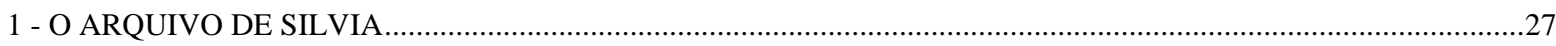

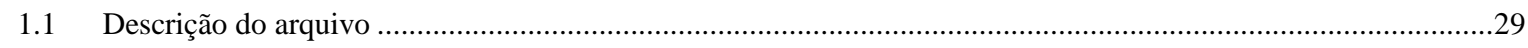

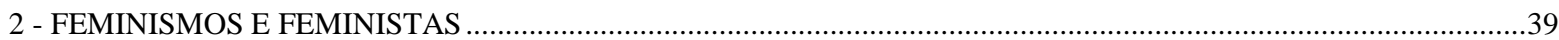

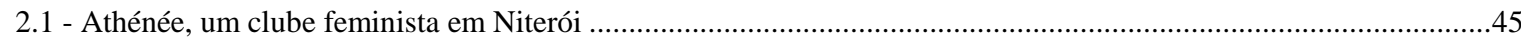

2.2 - Escritório de Ligação Feminina Geral e Estudos Sociais de Niterói......................................................................54

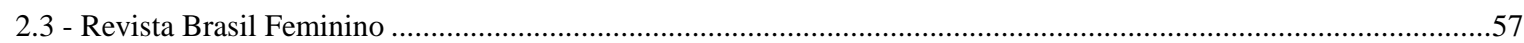

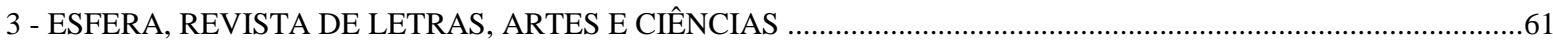

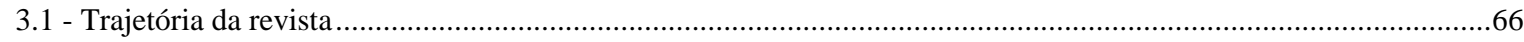

3.2 - Rio de Janeiro, Bar Amarelinho e Revista Dom Casmurro …............................................................................ 70

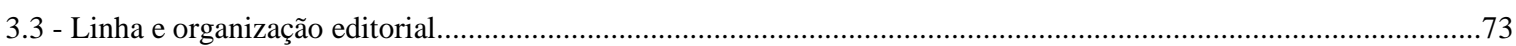

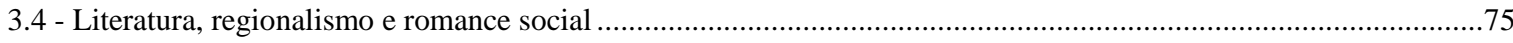

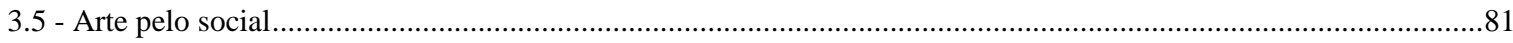

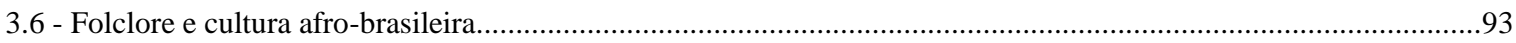

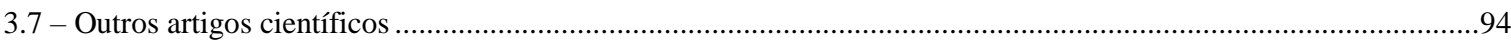

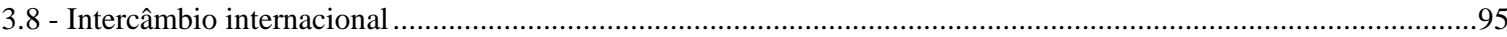

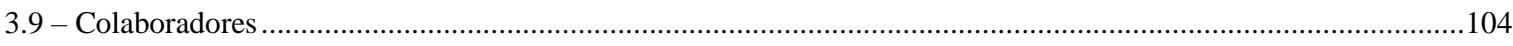

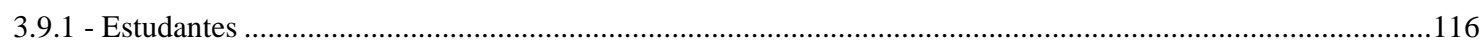

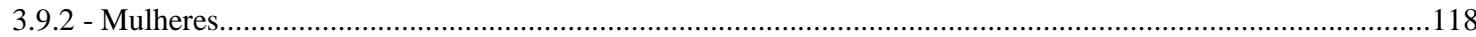

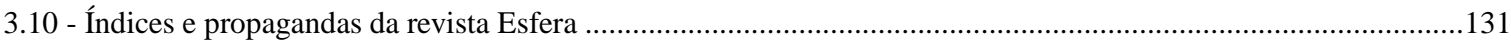

4 - A TÍTULO DE CONCLUSÃO: MODERNA, FEMINISTA E COMUNISTA ............................................................149

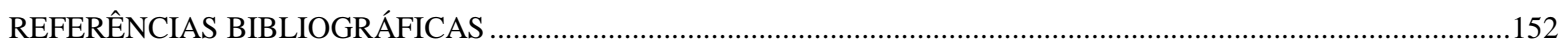

Bibliografia e referências bibliográficas dos perfis das personalidades citadas ….....................................................159

ANEXO 1 - Currículo Sylvia de Leon Chalreo - Jornalismo …...............................................................................195

ANEXO 2 - Currículo Sylvia de Leon Chalreo - Artes Plásticas ............................................................................198 


\section{INTRODUÇÃO}

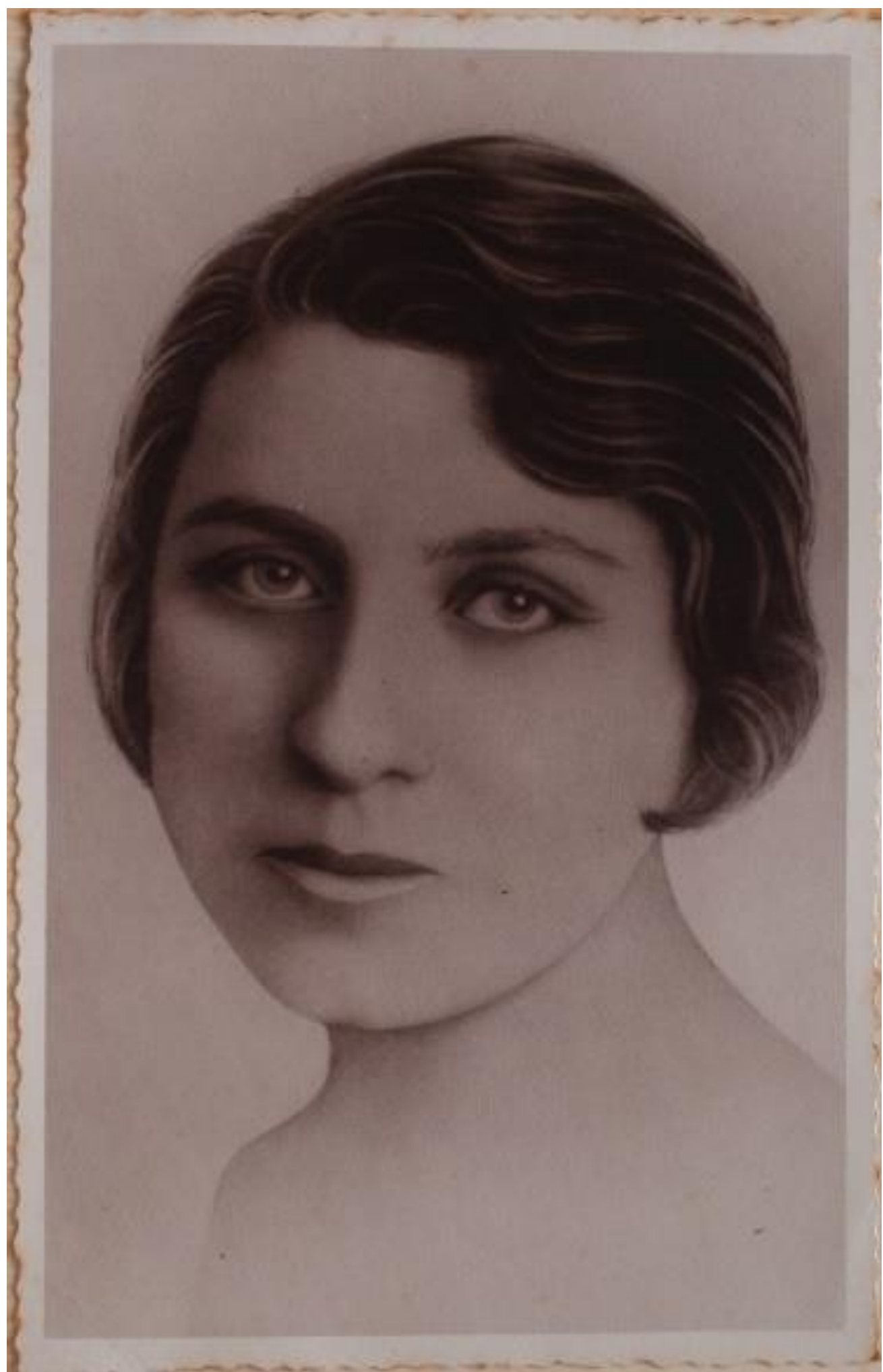

Figura 1 - Sylvia de Leon Chalreo, c. 1931. Fonte: Arquivo Silvia 
Ouvi falar sobre Silvia pela primeira vez através das lembranças de uma amiga. Ela ainda conta, com orgulho, que nas décadas de 1960 a 1980 conviveu com artistas na casa de seu tio Pedro ${ }^{1}$, no Rio de Janeiro. Que o tio morava com Silvia, uma artista plástica famosa e com o ator Labanca², em um apartamento onde circulavam pessoas conhecidas, atuantes no teatro e na televisão. Logo depois conheci o apartamento, que fica no bairro do Flamengo.

Quando entrei pela primeira vez me vi diante de um espaço que parecia parado no tempo. Móveis coloniais misturados a modernistas, prateleiras repletas de esculturas, livros, quadros cobrindo quase que totalmente as paredes das salas e corredores e o ateliê de Silvia, que apesar de passados 10 anos de sua morte ainda abrigava uma biblioteca e uma mapoteca com documentos, despertaram minha curiosidade.

Possuidor do poder dos museus e das coleções de arte, “de permitir aos objetos que o compõem desempenhar o papel de intermediários entre os espectadores, quaisquer que eles sejam, e os habitantes de um mundo ao qual aqueles são exteriores" (POMIAN, 1984:67), o apartamento e seus objetos mostraram sinais de mundos nos quais Silvia atuou, o que deu asas a minha imaginação e originou esta pesquisa.

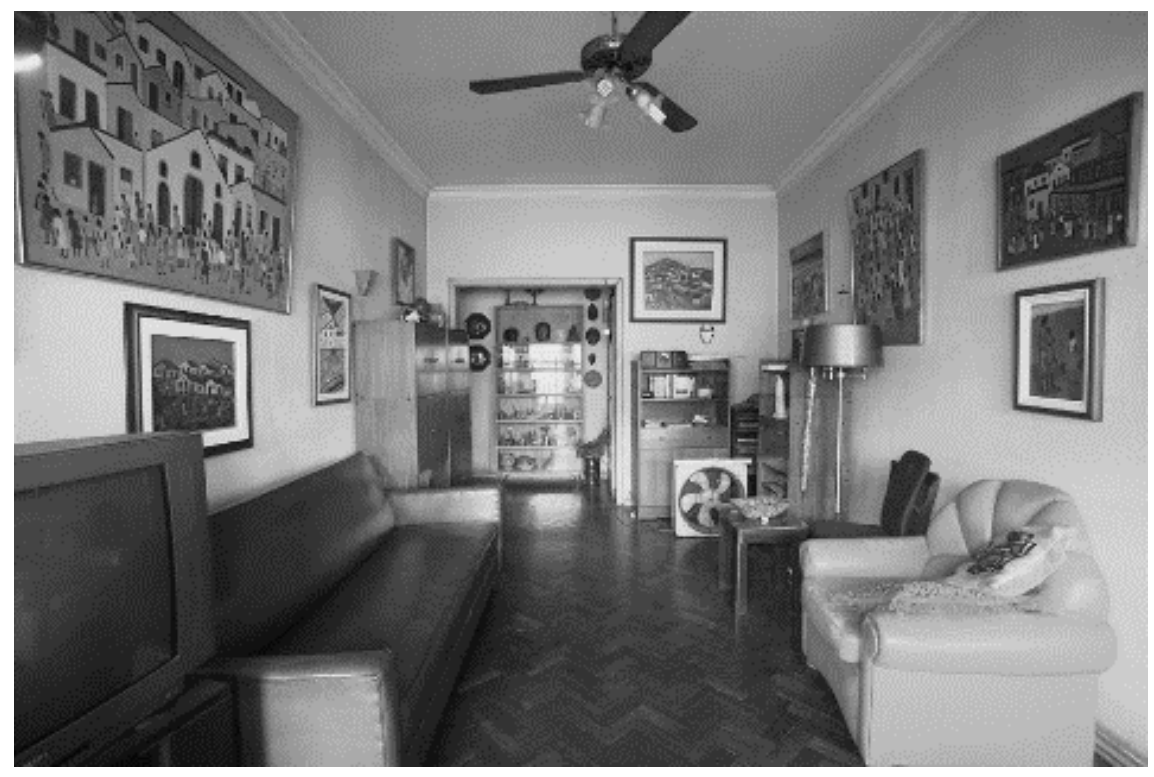

Figura 2 - Apartamento onde Silvia morou de 1956 a 1991. Foto: 2016

\footnotetext{
${ }^{1}$ Pedro Weiss Xavier.

${ }^{2}$ João Ângelo Labanca foi sindicalista, ativista político e pesquisador de teatro. Doou em vida seu arquivo e biblioteca para a antiga Fundacen (Fundação Nacional das Artes Cênicas), que incorporou partes aos acervos do Amorj - Arquivo de Memória Operária do Rio de Janeiro, e às bibliotecas da Coordenação de Folclore da FUNARTE e do Museu Histórico Nacional. Parte do acervo está sendo organizado e faz parte do projeto "memória das artes" da Funarte. Disponível em: <http://www.funarte.gov.br/brasilmemoriadasartes>. Acesso em 16 de janeiro de 2018.
} 


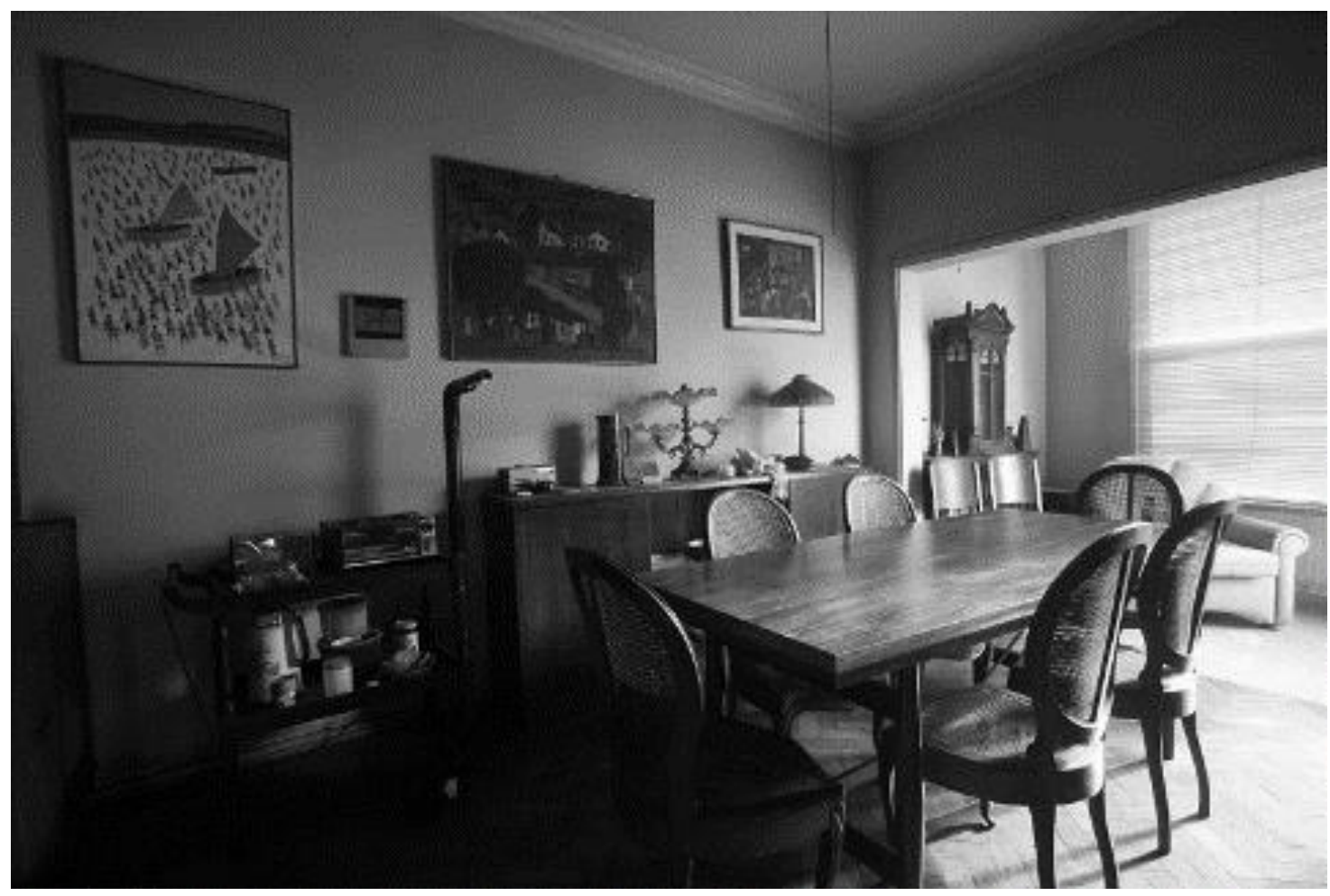

Figura 3 - Apartamento onde Silvia morou de 1956 a 1991. Foto: 2016

Sylvia de Leon Chalreo nasceu no morro do Barro vermelho, região central do Rio de Janeiro, em 11 de abril de 1905 e faleceu em 1991. Morou em Niterói, mas passou a maior parte da vida no Rio. Foi jornalista, escritora, tradutora e artista plástica. Enquanto jornalista foi a responsável pela editoria e direção da Revista Esfera, de Letras, Artes e Ciência, publicada e distribuída com o apoio do PCB de 1938 a 1950. Trabalhou na área administrativa da Prefeitura do Rio de Janeiro e foi militante feminista e do Partido Comunista Brasileiro.

Como artista plástica obteve prestígio: suas pinturas fazem parte de coleções de museus de arte moderna e arte Naïf do Brasil e do exterior ${ }^{3}$ e durante as décadas de 1960 a 1980 eram vendidas em leilões, feiras e galerias de arte alcançando valores consideráveis. Segundo o marchand Jorge Montmartre, em reportagem da revista O Cruzeiro de fevereiro de 1962, conservada no arquivo de Silvia, nesta época seus quadros estavam cotados entre 100 mil e 200 mil cruzeiros. Em 1979, quando Silvia realizou doações para diversos museus, os avaliou entre 20 e 40 mil cruzeiros. Um valor considerável, visto que nos anos 60 um quadro de Di Cavalcanti ou Djanira podia ser comprado por 300 mil cruzeiros. Sua biografia também fez parte de livros e dicionários sobre Arte Naïf e arte brasileira do período, entre eles o Dicionário das Artes Plásticas no Brasil de Roberto Pontual;

\footnotetext{
${ }^{3}$ Ver Anexo 2
} 
Dicionário Brasileiro de Artistas Plásticos, editado pelo Ministério da Educação e Cultura em 1974 e o Dictionnaire des peintres Naïfs du monde entier, edição francesa organizada por Anatole Jakovsky em 1976.

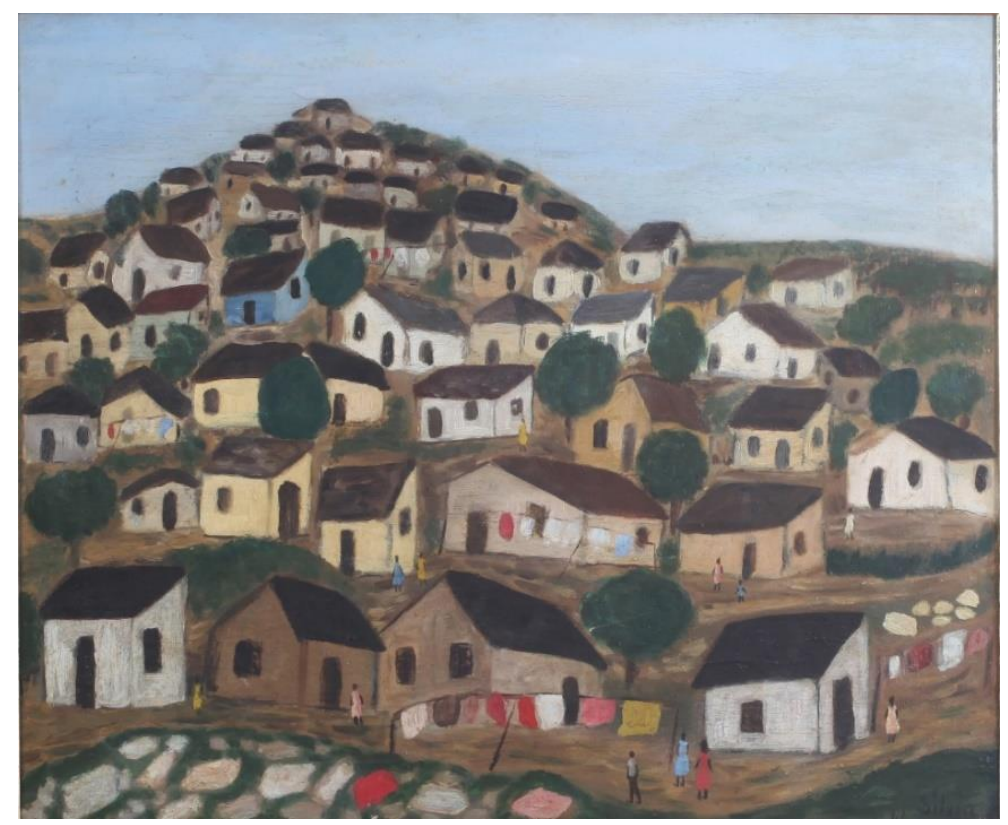

Figura 4 - Silvia, Favela, 1946, 52 ×53,5 cm, óleo sobre tela. Coleção Particular

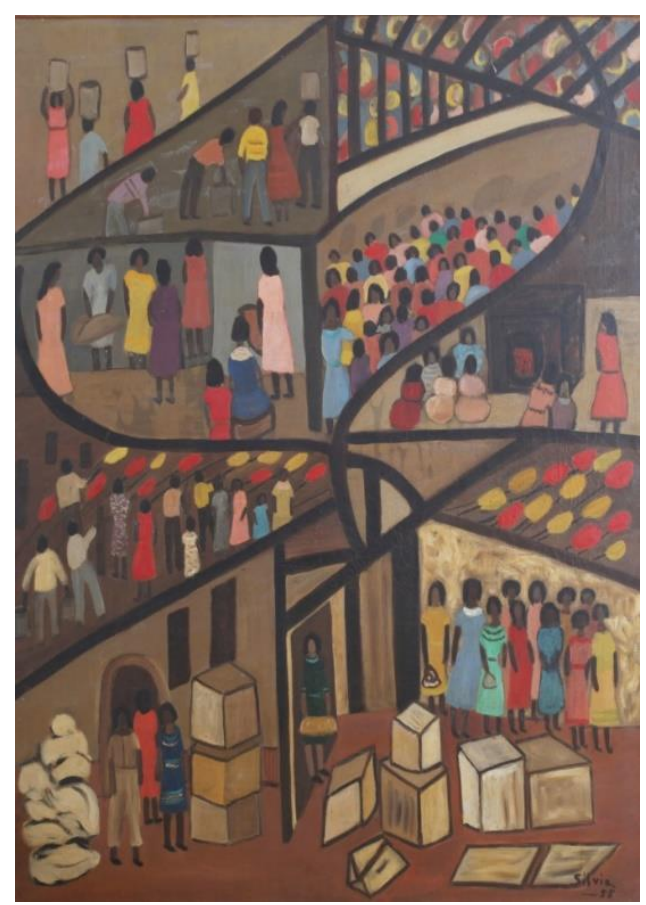

Figura 5 - Silvia, Fábrica de Vidro, 1944, óleo sobre tela. Coleção Particular 


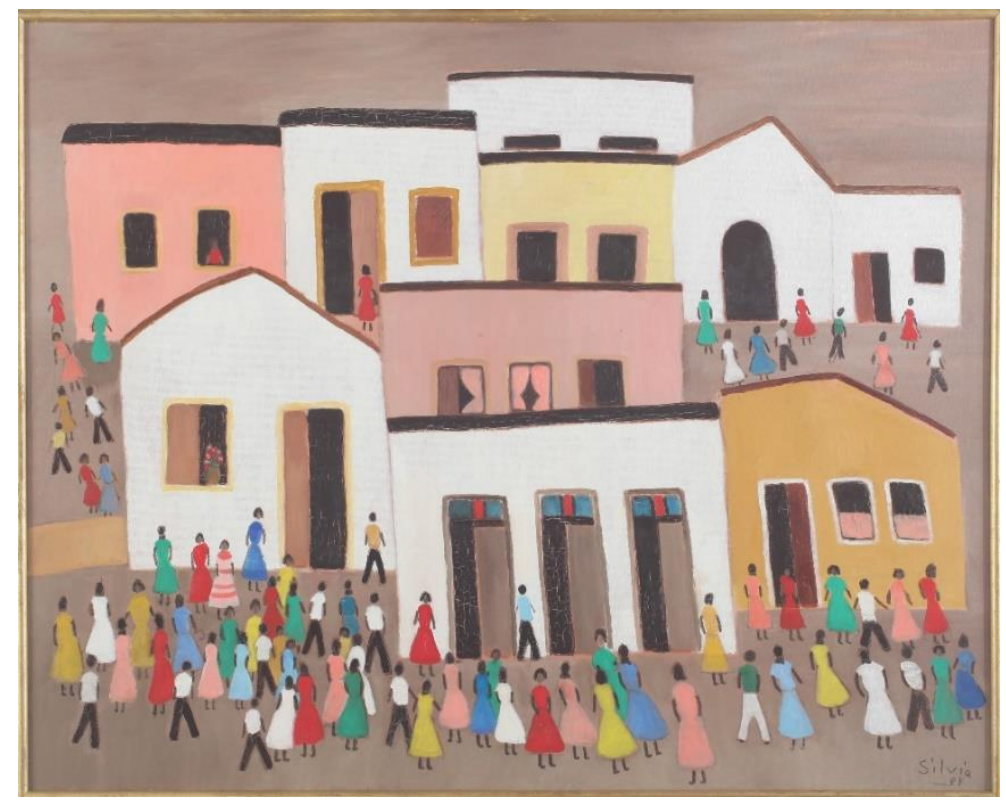

Figura 6 - Silvia, Gente e casa, 1984, óleo sobre tela, 65,2 x $81 \mathrm{~cm}$. Coleção Masp-Museu de Arte de São Paulo Assis Chateaubriand

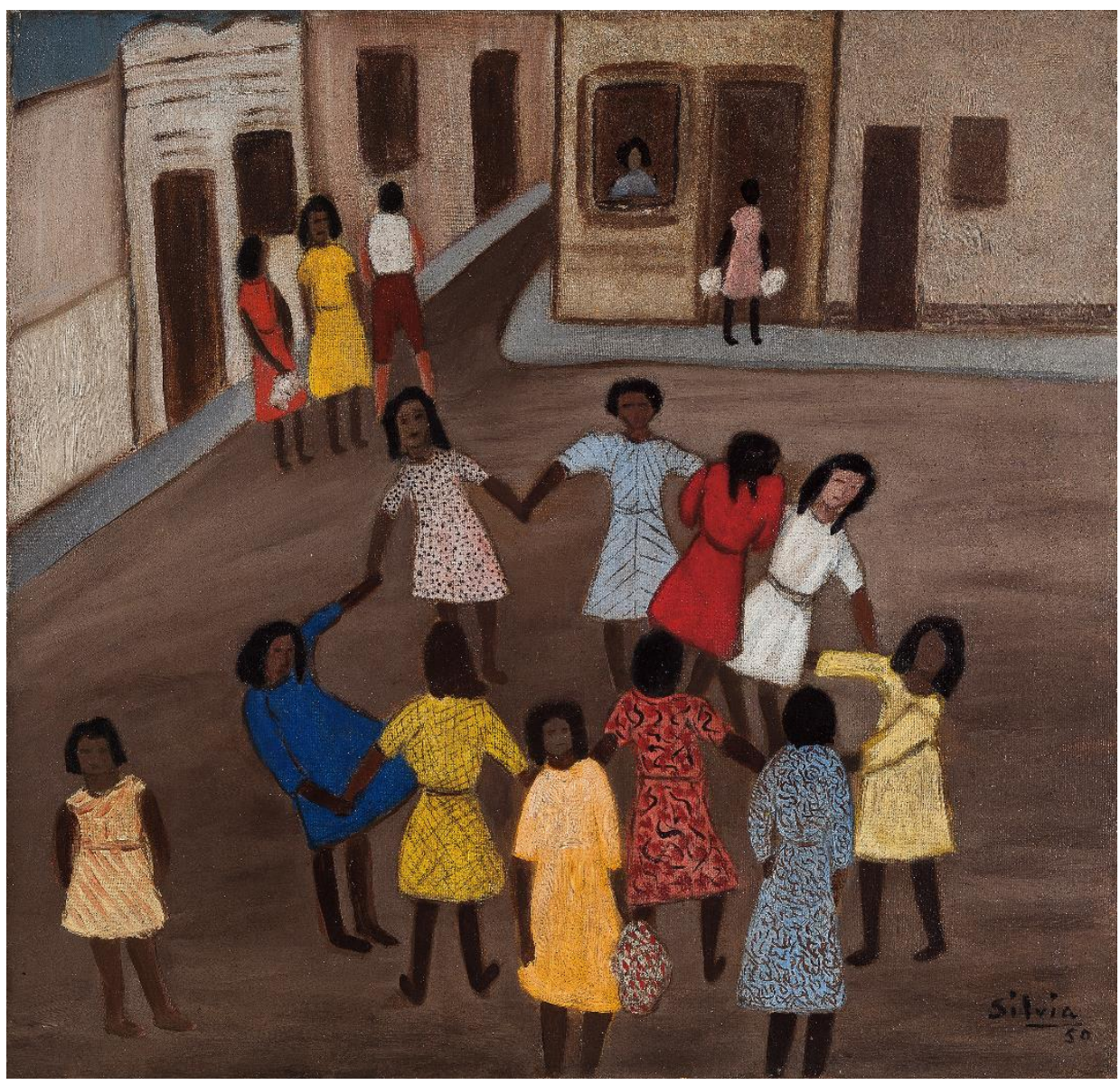

Figura 7- Silvia, Roda, 1950, óleo sobre tela, Coleção MAM, Rio de Janeiro, doação Miguel Paranhos do Rio Branco 


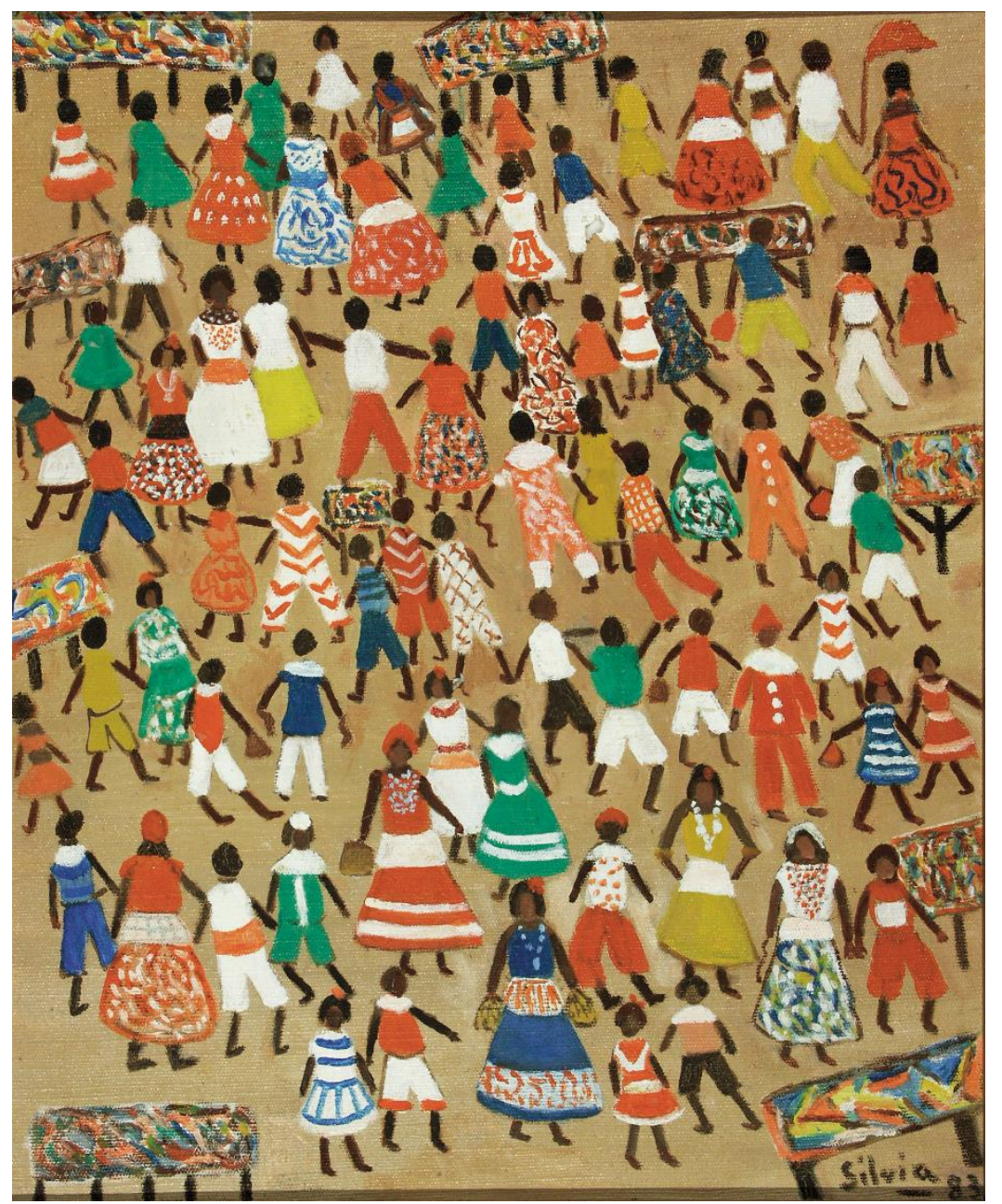

Figura 8 - Silvia, Fantasias, 1983, óleo sobre tela, 46 x 38 cm, Coleção Museu Anatole Jakovsky

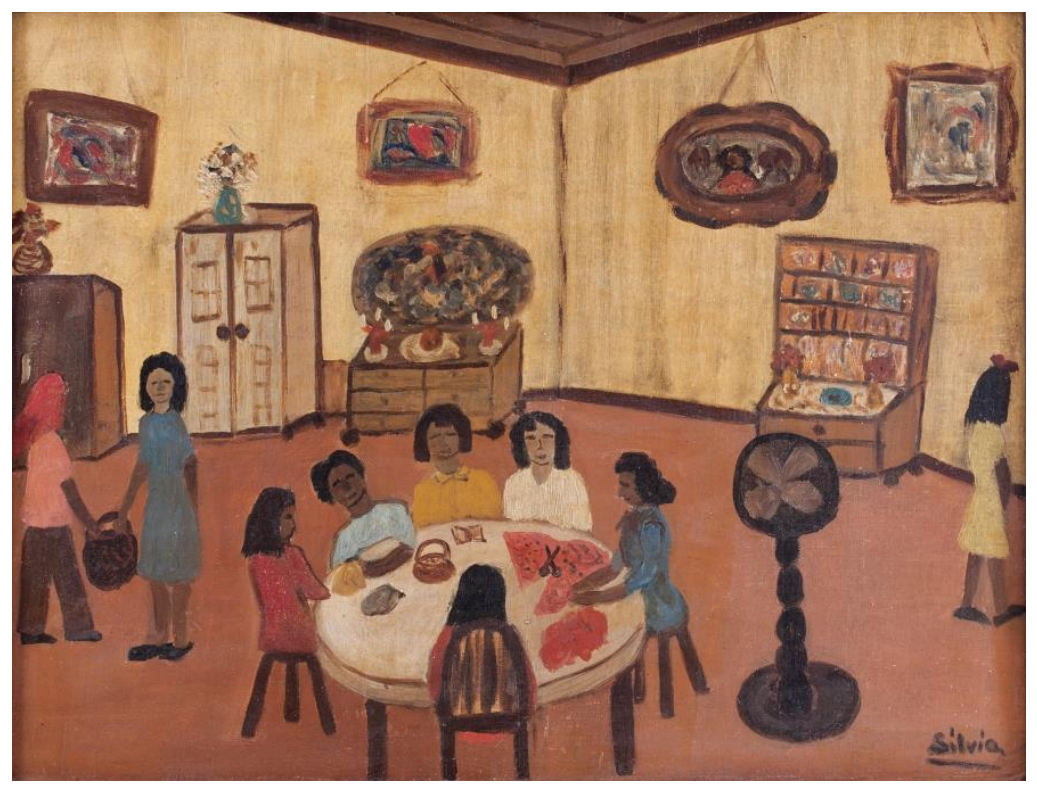

Figura 9 - Silvia, As Costureiras, 1959, óleo sobre tela, 48 x 60 cm, Coleção Galeria Jacques Ardies 
No entanto, a partir dos anos 1980 sua obra começou a sair de circulação e na atualidade está praticamente esquecida. Afora o meu esforço, que se soma ao do galerista Jacques Ardies ${ }^{4}$, especializado em arte Naï, quase nada se fala sobre ela. Dentre os livros consultados para esta pesquisa, seu nome só é mencionado na obra de Frederico Morais, Cronologia das Artes Plásticas no Rio de Janeiro (MORAIS, 1995:181, 232, 279) e no livro A arte no Brasil nas décadas de 1930 e 40 - O Grupo Santa Helena (ZANINI, 1991:36, 66, 79), ambos escritos no século passado. Sua obra também não foi selecionada para as exposições sobre mulheres artistas que ocorreram no Museu de Arte do Rio de Janeiro (MAR), em 2016, e no Instituto Tomie Otake de São Paulo, em $2017^{5}$.

Por que então guardar o arquivo e a memória de uma mulher artista que não se insere no cânone da historiografia da arte? Primeiro, pela carência de arquivo de mulheres nas instituições de pesquisa especializadas, conforme demonstra a tabela abaixo, o que além de refletir a desigualdade entre os gêneros de nossa sociedade, reforça o silêncio sobre sua história.

Figura 10 - TABELA 1 - ARQUIVOS DE MULHERES EM INSTITUIÇÕES CULTURAIS NO BRASIL (MAIO/2018)

\begin{tabular}{|l|l|l|l|}
\hline Instituição & Documento & $\begin{array}{l}\text { Arquivos/ } \\
\text { Homens }\end{array}$ & $\begin{array}{l}\text { Arquivos/ } \\
\text { Mulheres }\end{array}$ \\
\hline MIS - SP & Guia de Fundos e Coleções & 9 & 1 \\
\hline CEDAE-UNICAMP & Guia do Acervo & 29 & 4 \\
\hline IEB - USP & Guia do Acervo & 65 & 11 \\
\hline FUNARTE & CEDOC & 51 & 15 \\
\hline FGV & CPDOC & 150 & 5 \\
\hline Centro da Memória da & Guia de Coleções Pessoais & 18 & 0 \\
\hline Eletricidade & & 30 & 4 \\
\hline UNESP & CEDEM & 29 & 1 \\
\hline Casa de Oswaldo Cruz & Guia do Acervo & 29 & 0 \\
\hline Arquivo Nacional & Lista de Fundos e Coleções & 252 & 2 \\
\hline particulares & Guia de fundos online & 99 & \\
\hline IHGB Rio de Janeiro & & 29 & \\
\hline
\end{tabular}

\footnotetext{
${ }^{4}$ Jacques Ardies possui em sua coleção obras de Silvia que eventualmente são expostas na galeria. Também publicou reproduções de seus quadros em dois livros que produziu com incentivo da Lei Rouanet: A Arte Naif no Brasil (1998) e A Arte Naif no Brasil II (2014).

${ }^{5}$ No Museu de Arte do Rio (MAR), Tarsila e as mulheres modernas do Rio e no Instituto Tomie Othake, Invenções da Mulher Moderna, para além de Anita e Tarsila.
} 
Em segundo lugar, a trajetória de Silvia, que desde jovem circulava entre intelectuais e artistas do Rio de Janeiro, representa um espaço expressivo da atuação deste grupo frente ao avanço do fascismo e à difusão do comunismo nas camadas médias da sociedade brasileira.

E por fim, apesar de pequeno se comparado a arquivos de grandes personalidades, o arquivo de Silvia guarda vestígios de aspectos da vida cotidiana, social, religiosa, econômica e cultural do século XIX e XX no Rio de Janeiro e no Brasil; serve como fio condutor para se conhecer histórias do mundo artístico, intelectual e político no qual ela circulou e, pela sua própria natureza, pois traz ao pesquisador a oportunidade de ouvir uma voz feminina falar sobre si e seu universo, ajuda a suprir, mesmo como uma gota num oceano, "a falta de fontes não sobre as mulheres nem sobre a mulher, mas sobre sua existência concreta e sua história singular" (PERROT, 2007:22).

Interdisciplinar, a dissertação utiliza metodologias da história e sociologia e aborda os temas arte e literatura social e gênero no Rio de Janeiro na década de 1930. Acaba em 1940, quando Sylvia, aos 36 anos, iniciou-se nas artes plásticas. Em 1941, ela escreveu uma carta onde deixou claro a existência deste marco divisório em sua vida, que tomei por referência pois a partir de então ela passou a ocupar outra função no mundo das artes.

E agora surgiu o inesperado em minha vida. Um dia acordei pintora. Foi em agosto do ano passado. Com alguns fracassos consumados ultimamente percebi a falta de um caminho que conjugasse meu sentimento e minha maneira pessoal de ser. ${ }^{6}$

O cenário mundial da década de 1930 foi marcado no País por uma crise econômica, desemprego e fome, pela difusão e implantação dos regimes totalitários na Europa e América Latina e pela deflagração da Segunda Guerra Mundial. No Brasil, se iniciou com o golpe de estado de 1930, que revogou a constituição de 1891, dissolveu o Congresso Nacional e instituiu o governo autoritário de Getúlio Vargas. O período também foi marcado pela difusão do ideário comunista pelo mundo através das ações da Internacional Comunista e por sua penetração nas camadas médias da população brasileira, através, principalmente, de publicações na imprensa e do apoio do partido à criação e edição de periódicos de arte, cultura, ciências e política. O modernismo, gestado no decênio anterior, vivia um processo de rotinização e normalização,

Os intelectuais, cingidos pelas ideologias políticas do momento, numa polarização aguda entre comunistas, católicos e fascistas, lançaram-se no debate dos problemas sociais do país

${ }^{6}$ CARTA à Afonso de Castro Senda. Revista Mundo Uruguayo, Montevidéu, 17/07/1941. Recorte de Jornal/Arquivo Silvia. 
e voltaram-se para a investigação e o estudo da nossa realidade. "O Brasil começou a se apalpar" (Candido apud Pontes 2001a:6). A realidade brasileira tornou-se o conceito chave do período, encarnando-se nos estudos histórico-sociológicos, políticos, geográficos, econômicos e antropológicos. [...]Tal configuração expressou-se em diversos setores da vida cultural do país: na instrução pública, nas reformas do ensino primário e secundário, na produção artística e literária, nos meios de difusão cultural, na fundação de novas faculdades e das primeiras universidades brasileiras (PONTES, 2008:513).

Embora não tenha ficado satisfeita com sua incursão na literatura (realmente afora algumas poesias de foro íntimo e artigos jornalísticos publicados na revista Esfera não há nenhum texto literário de sua autoria no arquivo), este período de sua vida foi marcado por uma intensa atividade junto a associações feministas e ao PCB. No começo da década de 1930 liderou um grupo de mulheres que fundou um clube feminista em Niterói, participou da criação e administração de uma instituição de estudos sociais na cidade e colaborou, como redatora, na revista Brasil Feminino. No final da década, em 1938, sob a orientação do PCB, criou e foi a principal responsável pela edição da revista Esfera, de Letras, Artes e Ciências.

O objetivo não foi fazer uma biografia, mas usar o arquivo de Silvia e seus documentos como fonte e fio condutor para trazer à tona mundos da arte dos quais participou por meio do exame micro localizado de sua vida. Para isto me vali da micro história e do método indiciário criado pelo historiador italiano Carlo Ginzburg e da metodologia para o estudo da arte do sociólogo americano Howard Becker.

Ginzburg parte do seguinte pressuposto: "Se a realidade é opaca, existem zonas privilegiadas - sinais, indícios - que permitem decifrá-la” (GINZBURG, 1989:177) e desenvolve uma investigação quase detetivesca, procurando nos mínimos sinais, imperceptíveis para a maioria das pessoas, nos vestígios da atividade humana, as respostas para suas questões.

Seus objetivos básicos foram resumidos pelo historiador Boris Fausto:

[...] reduzir a escala de observação do historiador, a fim de apreciar ações humanas e significados que passam despercebidos quando se lida com grandes quadros; concentrar essa escala em pessoas comuns e não em grandes personagens, buscando ouvir sua voz; extrair de fatos aparentemente corriqueiros uma dimensão sociocultural relevante; apelar para o recurso da narrativa, ao contrário da história das grandes estruturas, sem entretanto confundir-se dado seu conteúdo e seu estilo - com as narrativas tradicionais, predominantes no século XIX e situar-se no terreno da história, o que significa apoiar-se nas fontes, delimitando-se assim, claramente, a obra ficcional (FAUSTO, 2009: 9). 
Tomei o arquivo de Silvia, entre tantos arquivos perdidos de mulheres artistas esquecidas, o conteúdo, formato, origem e sinais de seus documentos textuais, objetos e obras de arte e os vínculos entre eles, como índices para, ressaltando a participação feminina, decifrar a ação de um grupo de artistas e intelectuais ativos na década de 1930 cuja história foi pouco difundida pela historiografia da arte e literatura brasileira. Relacionados a outras fontes, orais, arquivísticas e bibliográficas, os documentos encontrados no arquivo de Silvia foram o "pontapé inicial” para o desenvolvimento desta pesquisa.

Howard Becker propõe uma investigação sobre arte que ultrapasse a análise e interpretação das obras em si e o entendimento de que elas são produto de um indivíduo, o artista, que a converte na materialização de uma verdade íntima e singular. Segundo Becker, para que uma obra de arte seja criada é necessária a ação coletiva, que compreende a ideia inicial até a sua execução, considerandose entre outras atividades fundamentais, a distribuição, financiamento e apoio. Os participantes desta ação coletiva organizam-se basicamente através de entendimentos prévios e normas construídas através da experiência, que a facilitam, as convenções. Para que exista uma obra de arte, portanto, é necessário a existência de mundos da arte. Nestes mundos de arte, ainda segundo Becker, convivem profissionais integrados, que respeitam as convenções e têm, portanto, menos liberdade criadora; os que inovam, mas não formam um mundo organizado em torno destas inovações, os mavericks; os que estão totalmente à margem do mundo profissional, mas respeitam algumas convenções, os artistas populares, e os Naïfs, que sem qualquer relação com o mundo artístico, não respeitam a linguagem convencional e nem se inscrevem em nenhuma tradição ou solução artística, produzindo obras relacionadas ao seu mundo pessoal.

Ao tomar contato com a documentação me deparei com este grupo heterogêneo, formado por artistas convencionais, populares, mavericks e naïfs atuantes em diferentes atividades artísticas, cujos principais vínculos eram a posição política alinhada ao combate ao fascismo internacional e a participação no debate modernista em diferentes localidades e períodos.

A pesquisa se deteve inicialmente no estudo sobre a função que Silvia ocupava neste mundo das artes - nesta primeira fase de sua vida fez parte desta rede não como artista, ou seja, como diz Becker, como a portadora de ideias que deram origem à obras de arte, mas atuou como produtora e agitadora cultural, jornalista e editora da revista Esfera.

O segundo momento da pesquisa foi a identificação do perfil biográfico dos outros intelectuais que participaram desta rede, procurando descobrir sua posição política, classe social, outras profissões que exerciam, seu prestígio na época e hoje em dia, suas posições frente às convenções e os vínculos 
que, além do arquivo de Silvia, os uniam. Em decorrência, apareceram os outros atores da ação coletiva: associações e eventos culturais, editoras, patrocinadores e críticos.

A teoria de Howard Becker norteou a construção desta narrativa e nos levou para outras fontes além do arquivo de Sylvia, mas os estudos arquivísticos de Phillipe Artières e Arlete Farge foram os subsídios teóricos para o trabalho de interpretação do arquivo. Artières, no artigo Arquivar a própria vida, destaca o processo de acumulação em arquivos pessoais e sua relação com a noção de verdade que os documentos podem trazer levando em consideração a ação intencional ou não do acumulador do arquivo e de familiares ou profissionais que tenham trabalhado em sua organização, enquanto Arlete Farge no seu livro $O$ Sabor do Arquivo traz uma reflexão sobre os procedimentos para a leitura e interpretação dos documentos de arquivo, considerando além de seu conteúdo e materialidade, a relação que o historiador estabelece com ele. Os vestígios deixados, segundo ela, tornam-se representações do real e o trabalho com o arquivo constitui um movimento contínuo de aproximação e distanciamento entre o sentido e a verdade, o singular e o coletivo. Nestas idas e vindas, mundos sociais se descortinam.

Em se tratando da trajetória de uma mulher que vivia os mundos da arte e literatura na década de 1930, o conceito de modernismo foi amplamente utilizado. Me apoiei nas reflexões a seguir para examinar como os diferentes mundos sociais representados na vida de Silvia manifestavam a modernidade no período. No livro Modernismo no Rio de Janeiro, Mônica Pimenta Velloso reflete sobre o modernismo como um processo dinâmico, que consiste nas "diversas manifestações sociais pelas quais se veicula a ideia de moderno" (VELLOSO, 1996: 33), assim, movimentos e políticas públicas, mudanças de comportamento no cotidiano, pesquisas cientificas, enfim, expressões de outros mundos sociais além do artístico e literário integram este processo. Neste mesmo texto a autora, a fim de relativizar a Semana de 22 como marco do modernismo no Brasil, aponta as diversas temporalidades que estão contidas neste conceito. Segundo ela, “[...] o modernismo passa a ser compreendido como um processo que vai acarretando mudanças significativas de tempo e espaço, fazendo coexistir múltiplos valores culturais" (idem, 1996: 32). Ana Paula Simioni por sua vez, afirma que a década de 1930 "pode ser considerada a época de maturação e oficialização do movimento" modernista, onde as políticas culturais de Gustavo Capanema, ministro da educação e saúde do governo Getúlio Vargas, foram implementadas no sentido de promover a integração nacional em torno da construção de símbolos identitários da brasilidade pela busca de uma cultura nacional (SIMIONI, 2014: 5). E por fim levei em consideração Marília A. Ribeiro, quando descreve as principais características do modernismo brasileiro: 
[...] as propostas dos modernistas podem ser sintetizadas nas seguintes ações: organizar exposições, festivais e publicações em forma de manifesto; derrubar os cânones que legitimavam a criação artística; proclamar o direito permanente à pesquisa estética, a atualização da inteligência artística brasileira e o estabelecimento de uma consciência crítica nacional (RIBEIRO, 2007: 120).

O primeiro capítulo, $O$ arquivo de Silvia, consiste na narração do processo que vai desde o primeiro contato com o apartamento até a elaboração da descrição do acervo ali existente, e nas reflexões sobre arquivos pessoais decorrentes desta vivência. Nos capítulos seguintes reconstruí fragmentos da trajetória de Silvia na década de 1930, quando ela estava em contato com intelectuais, artistas, estudantes, militantes antifascistas, comunistas e feministas de diferentes localidades do Brasil e do mundo, o que resultou num olhar panorâmico, pois micro localizado na trajetória de vida de Silvia, onde eventos de curta duração se revelam e diferentes mundos de arte se cruzam e manifestam a modernidade.

O espaço de uma dissertação contém limites e fazer escolhas é sempre abdicar de algo. Este olhar panorâmico e micro localizado, na medida em que revela mundos invisíveis esbarra com estes limites, pois os mundos que se descortinam não cabem na dissertação. Os eventos e personalidades aqui reunidos são vistos em relação aos vínculos que possuem entre si e com a trajetória de vida de Silvia; alguns já foram objeto de estudo em diferentes disciplinas e os livros, teses e dissertações conhecidos estão referenciados neste trabalho, outros são anônimos e pouco conhecidos e constituem, a meu ver, possíveis objetos para novas pesquisas. Da mesma forma, a Relação de propagandas na Esfera, levantamento realizado no início da pesquisa e não desenvolvido e as imagens, utilizadas de forma ilustrativa, como uma maneira eloquente de aproximar o leitor de objetos, obras de arte, mulheres e locais que fizeram parte do mundo de Silvia, são apresentados como novas fontes ou objetos de pesquisa.

Feminismos e Feministas traz à luz, a partir das informações encontradas em recortes de jornal guardados no apartamento, o clube feminista criado por Sylvia, o Athénée Club, seu evento de inauguração com apresentações musicais e literárias, A Hora da Arte, e o evento Noite Brasileira de Música e Poesia promovido pela associação; o Escritório Geral de Ligação Feminina e Estudos Sociais e a revista Brasil Feminino. Sylvia foi uma das fundadoras de ambas as associações em Niterói, a organizadora dos eventos e colaboradora da revista. A Hora da Arte e a Noite Brasileira de Música e Poesia trazem uma rede de músicos, atrizes e atores conhecidos na época e uma rede de mulheres ligadas ás lutas pela emancipação feminina. 
O capítulo seguinte trata da participação dos intelectuais e artistas na luta antifascista e como esta luta está representada na Esfera. Fazem parte deste capítulo o Índice das revistas Esfera 1 a 24 e a já mencionada Relação de Propagandas veiculadas nestes números da publicação, separadas em Comércio e Serviços, Empresas de radiodifusão e Mercado Editorial (propagandas de livros, periódicos e editoras).

Vale notar também as duas grafias utilizadas para escrever o nome de Silvia: no final da década de 1930, já nas páginas da Esfera, seu nome aparece grafado substituindo o y pelo i. A prática não era tão incomum, muitas pessoas, principalmente ligadas ao mundo intelectual e artístico, fizeram esta mudança como forma de reafirmar a nacionalidade brasileira. Optei por grafar o seu nome em acontecimentos ocorridos até a Esfera com y e com i quando se insere em referências gerais ou se refere a acontecimentos posteriores a mudança representada na revista.

Uma parte da investigação foi feita pela internet, priorizando o uso de teses e dissertações disponibilizadas na rede, de artigos publicados em sites de revistas especializadas, instituições culturais e educacionais, anais de congressos e seminários e em matérias publicadas em jornais e revistas disponibilizados na Hemeroteca Nacional Brasileira. Algumas vezes, pela total falta de acesso a outras fontes, decorrente do anonimato nos estudos literários e artísticos a que ficaram relegados alguns dos escritores e artistas, foram utilizadas criteriosamente informações de blogs e enciclopédias culturais. O uso da tecnologia se justifica pela amplitude da pesquisa e a diversidade dos temas: foram pesquisados cerca de duzentos perfis biográficos e dados sobre dezenas de associações e eventos relacionados à literatura, música, teatro, artes plásticas e ciências sociais em diferentes localidades do País, América Latina e Europa. Utilizei também como fonte de pesquisa os depoimentos dos familiares Amabeny Zoet, Márcia Zoet e Renata Zoet, do galerista Jacques Ardies e da vizinha de apartamento no edifício do Flamengo, Ana Maria Magalhães.

Por fim, algumas informações complementares: Os currículos de jornalista e artista plástica de Silvia estão anexados a este trabalho (Anexos 1 e 2). A bibliografia e fontes utilizadas e conhecidas durante a pesquisa biográfica estão referenciadas por nome em Bibliografia e referências bibliográficas dos perfis das personalidades citadas, que deve ser consultado para se conhecer as fontes utilizadas para a elaboração dos perfis biográficos (por isto, no caso de informações biográficas as referências bibliográficas só constam no corpo do texto quando há citações).

As revistas número um a catorze foram digitalizadas e estão disponibilizadas online ${ }^{7}$.

\footnotetext{
${ }^{7}$ Acesso no link: <http://www.illumina.fot.br/ill_pagina.php?mpg=07.00.00>.
} 


\section{1 - O ARQUIVO DE SILVIA}

"O arquivo é excesso de sentido quando aquele que o lê sente a beleza, o assombro e um certo abalo emocional” (FARGE, 2009:36).

Tive estas sensações ao conhecer a residência onde Silvia morou de 1956 até morrer. Essa casa tem muito a dizer. Tanto pelo que guarda quanto por aquilo que falta, pela história que não quer contar; pela história para a qual serve de pista e que atiça a curiosidade do pesquisador.

Todos nós deixamos após a nossa morte artefatos ou textos produzidos ou recebidos durante nossa vida. Todos, ou quase todos, deixamos um arquivo que contém informações para o conhecimento de fragmentos do cotidiano, pensamentos ou sentimentos e que refletem uma experiência em comum com outros indivíduos. Se pensarmos na história do cotidiano, da culinária, da moda, da higiene, da tecnologia ou das mulheres, todos os artefatos, textos e imagens que compõem a herança de uma pessoa são a princípio documentos que informam sobre o gosto, modo de viver, posição social, relacionamentos e necessidades pessoais, mas também o gosto e necessidades das coletividades com quem compartilha a vida.

Olhei para o apartamento como se fosse um grande arquivo pessoal contendo diferentes tipos documentais, ou seja, objetos, documentos textuais, artísticos e imagéticos acumulados organicamente no decorrer de uma vida. Abrir cada gaveta, porta e pasta foi um trabalho que de certa forma me transportou para os mundos por onde Silvia passou. Pois mexer no arquivo de uma pessoa é como entrar num mundo virtual que te enreda, abre portas, mas também confunde, já que os vínculos entre os documentos se mostram aos poucos e as peças do quebra cabeças nem sempre se encaixam.

$\mathrm{O}$ arquivo pessoal também coloca o pesquisador em contato quase íntimo com eventos já conhecidos, pois ele passa a fazer parte daquele mundo que parecia distante; assim como o aproxima de acontecimentos que muitas vezes ficaram guardados só na esfera privada e que, frente a uma vida, recobram sua dimensão original e reaparecem. Com eles, trazem mundos e pessoas que se cruzam e, da existência individual, surgem pensamentos, atos, eventos e movimentos coletivos pouco conhecidos.

Neste apartamento arquivo há objetos utilitários, como móveis e peças de decoração, coleções de arte e artesanato contendo desenhos, gravuras, pinturas e esculturas, uma coleção de discos (1933 - 1984), uma pequena biblioteca de artes e literatura e uma série de documentos textuais e fotografias acondicionados em pastas e álbuns armazenados na mapoteca do antigo ateliê, algumas contendo o rótulo Sobre Sílvia. 
Estes últimos, intencionalmente selecionados para ajudar a lembrar, representam o que Philipe Artières chamou de "arquivar a própria vida", ou seja, uma maneira de publicar a própria vida, "uma prática de construção de si mesmo e de resistência", que não somente não é algo neutro, pois permite ao indivíduo se fazer ver tal como ele se vê e desejaria ser visto, mas também tem um aspecto público, visto que se dá em função de um leitor (ARTIÈRES, 1998).

\footnotetext{
Não arquivamos nossas vidas, não pomos nossas vidas em conserva de qualquer maneira; não guardamos todas as maçãs da nossa cesta pessoal; fazemos um acordo com a realidade, manipulamos a existência: omitimos, rasuramos, riscamos, sublinhamos, damos destaque a certas passagens (Idem, 1998:2).
}

Silvia se preocupou com seu arquivo. Nas pastas com o título Sobre Silvia escrito à mão ou com fita rotex, guardou fotografias, recortes de jornais, cartas, cartões postais, poesias e documentos sobre sua carreira de artistas plástica. Lembranças que selecionou como testemunho da sua vida, para recordar e tirar lições do passado, para preparar o futuro, mas, sobretudo para existir no cotidiano. Conservou do período da infância, fotografias selecionadas de antigos álbuns de família e realocadas em novos álbuns (algumas fotos possuem as marcas do papel e cantoneiras de onde foram retiradas), uma poesia, um cartão postal e um santinho de primeira comunhão; da sua juventude, fotografias, recortes de jornal contendo matérias sobre o clube feminista Athénée em Niterói e poesias manuscritas e datilografadas; e da vida de jornalista um currículo, algumas revistas contendo artigos e críticas de sua autoria e dois jogos completos da revista Esfera encadernados em cinco volumes cada. Além das telas de sua autoria expostas nas paredes de casa, guardou como testemunho de sua carreira nas artes plásticas desenhos, aquarelas e serigrafias, dossiês contendo correspondência com galeristas e museus, recibos de compra e venda de obras de arte, dossiês com documentação sobre exposições específicas, catálogos e convites de exposições, críticas à sua obra manuscritas, datilografadas e impressas em jornais, álbuns com fotografias de vernissages de suas exposições, fotografias de obras vendidas, listas de obras e currículos.

Levando em consideração a ilusão biográfica, ou seja, "a crítica que destaca a ingenuidade de se supor que o arquivo revela a existência de um eu coerente e contínuo pelo "efeito de verdade" que os documentos são capazes de produzir" (BOURDIER, 1997:183-191), procurei interpretar os sentidos do ato de arquivar, ou seja, o que Silvia pretendia ao conservar esta documentação e o que queria esquecer. 
Silvia não conservou correspondências íntimas ou profissionais (com exceção de bilhetes, cartões de felicitações e uma carta em francês, do artista Frans Masereel), nada que envolvesse explicitamente seu nome com o PCB e guardou poucas recordações da família. Nem todas as exclusões foram feitas por ela. Após a sua morte, Pedro, seu companheiro de moradia desde os anos 1950, provavelmente à pedido dela, picotou uma grande quantidade de documentos ${ }^{8}$.

Os significados destas lacunas podem ser explicados, em relação a sua militância política, pelo medo das perseguições aos comunistas durante a ditadura militar (1964 - 1985), se realizadas na década de 1970, quando ela montou pastas com recordações ${ }^{9}$ ou, se executadas posteriormente a sua morte por Pedro, como um desejo dele, ou dela, de deixar registrado apenas a sua vida de artista.

\subsection{Descrição do arquivo}

A descrição a seguir não segue nenhuma norma arquivística, mesmo porque em relação aos arquivos pessoais, muito foi e ainda é feito, muito se discute, mas a comunidade arquivística não chegou a um método normatizado para sua organização e descrição. Não há organogramas, regulamentos ou legislação, como nos arquivos institucionais, para orientar este trabalho.

Organizei os documentos de Silvia apenas com o intuito de poder localizá-los no decorrer desta pesquisa. Criei dois grandes grupos documentais, o primeiro, que chamei de Vida Pessoal, reúne a documentação produzida ou recebida em atividades do cotidiano relativas ao lazer, à subjetividade e à afetividade. O outro grupo é formado por documentos produzidos ou recebidos durante sua Vida Profissional. Como Silvia exerceu jornalismo e artes plásticas concomitantemente por um longo período, dividi este grupo em Artes Visuais e Jornalismo.

O produto não é um inventário nem um catálogo do acervo. Descrevi coleções, dossiês e unidades documentais indiscriminadamente. Para além do suporte, formato e conteúdo, procuro esclarecer o vínculo entre o documento e o arquivo. As perguntas que nortearam este trabalho foram: qual o evento que gerou este documento? Por que ele foi conservado?

\section{VIDA PESSOAL}

Documentos produzidos ou recebidos no exercício de relações familiares e afetivas e de atividades culturais e de lazer.

\footnotetext{
${ }^{8}$ Depoimento de Márcia Zoet, sobrinha de Pedro Xavier.

${ }^{9}$ Os modelos das pastas, álbuns e fitas adesivas utilizados para acondicionar e identificar documentos relacionados a recordações pessoais e a carreira artística (Sobre Silvia) eram populares neste período.
} 
COLEÇÕES

- Coleção de Autógrafos - 1936 - 1973 (11 documentos): autógrafos de pessoas públicas em fotografias, cartões, convites e programas de eventos culturais.

- Coleção de discos - 1930cc - 1980: discos de vinil, de 78 e 33 rpm, de música brasileira e estrangeira. Discos, capas e encartes em bom estado de conservação. Algumas peças têm a assinatura de Labanca e/ou Silvia.

- Coleção de livros de literatura - 1911 - 1968 (nove livros): seis livros sobre Joana D’Arc (J. Michelet, 1911; Amand Rastoul, 1930; Pierre Champignon, 1932; Edith Tomas, 1934; José Fuzeira, 1947; Aldo Brunetti, 1966), Cecília Meirelles: poemas italianos, 1968; Viola de Bolso, Carlos Drummond de Andrade e Auto da Mula do Padre, Hermilo Borba de Carvalho.

- Coleção de artesanato: Peças de artesanato brasileiro em cerâmica, barro, madeira e plantas, adquiridas por Labanca e Silvia em suas viagens por outros estados e oferecidas por terceiros, como lembrança de viagem.

\section{CORRESPONDÊNCIA PESSOAL}

- Correspondência ativa - (enviadas por Silvia) - (três documentos):

- Cartão com a dedicatória: Para Serafin e Blanca, com o abraço saudoso dos amigos pintores brasileiros. Assinada em conjunto com os pintores Durval Serra, Luis Santos e Quirino Campofiorito, 1943.

- Cópia heliográfica de carta enviada à Societè dês amis de George Sand, solicitando um catálogo e informações sobre as condições de venda para o exterior. Com o nome de Sylvia no espaço do remetente. Escrita em francês, em 24 de fevereiro de 1950.

- Cartão de boas festas enviado para Sophia e Malena, tias de Pedro Xavier. Assinada por Silvia, Labanca, Nenê e Schön (apelidos de sua mãe e tia). Natal, 1958.

- Correspondência passiva - (recebidas por Silvia - 35 documentos) - 1936 - 1989 : cartas recebidas de amigos, bilhetes de amor, cartas dos astrólogos Professor Dejamaro e Roxroy, carta da Societè dês amis de George Sand, cartões de boas festas e com dedicatórias. 
- Correspondência de terceiros: cópia de carta sem data, do músico Waldemar Henrique (1905 - 1995) para o músico Jorge de Oliveira Fernandes (1907-1989) e telegramas de pêsames pela morte de Silvia, remetidos para Pedro Xavier em 1991.

DOSSIE DOCUMENTOS ESCOLARES - 1920 - 1944 (18 documentos)

Cartões de matrícula, correspondências e recibos de pagamento de mensalidades. Escola Normal do Rio de Janeiro, Escola de Direito do Rio de Janeiro, Universidade de Petrópolis, Faculdade de Direito de Petrópolis, Universidade Livre do Distrito Federal

DOSSIE DE IMPRESSOS (Periódicos de 1931 a 1941 - quatro documentos)

- Artigo Para maior aproximação da mulher fluminense: fundação de um clube feminino em Niterói, veículo não identificado, divulgando a inauguração do Athénée Club, 28/07/1931.

- Epistolário: outra carta a outra amiga, artigo assinado por Afonso de Castro Senda, veículo não identificado, comentando a pedido de uma amiga (provavelmente Sylvia), sobre a morte e a obra literária de Charles Louis Phillipe, sd.

- Mentalidade Feminina Brasileira, artigo assinado por Afonso de Castro Senda, Revista A Ideia Livre, Anadia, Portugal, apresentando Sylvia como o exemplo da mulher moderna, 10/07/1937.

- Sylvia León Chalreo: Transformación de su fina expression artística, revista Mundo Uruguaio, reportagem sobre Sylvia contendo a reprodução de duas pinturas, uma poesia e uma carta, onde Silvia conta sobre sua iniciação no mundo das artes visuais, $17 / 08 / 1941$

\section{ÁLBUNS DE FOTOGRAFIAS}

- Fotografias da família - c. 1850 - c. 1915 - (33 fotografias): retratos de antepassados individualmente e em grupo. Cartões de visita. Alguns com anotações e dedicatórias. Contém um postal do Castelo de Trautmanndorf, localizado na atual Áustria. Carimbos de fotógrafos e casas fotográficas.

- Fotografias da família - c. 1950 - c. 1970 - (sete fotografias): retratos em grupo e individuais de Silvia, Labanca, Pedro, família de Pedro, Hortência de Leon (mãe) e Schön (tia). 
- Retratos de Sylvia - c. 1910 - 1935 - (cinco retratos).

- Viagens, eventos e pessoas - sd, décadas de 1930 a 1950 - (62 fotografias).

- Retratos Ramiro

- Quinze retratos 3x4 de Ramiro, guardados em um envelope.

- Retratos de Ramiro, fotos de Ramiro e Sylvia e de Ramiro em grupos de homens. Duas com dedicatória de Ramiro para Sylvia. Conservadas em um envelope e um álbum. Algumas com datas (entre 1935 e 1937).

POESIAS DE SYLVIA - 1918 - 1939 (17 poemas)

Poesias criadas por Sylvia, manuscritas e datilografadas, rascunhos, originais e cópias. Com dedicatórias para Ramiro e Afonso.

POESIAS PARA SILVIA - 1938 - 1978 (21 poemas)

Série de poesias dedicadas à Silvia. Poemas de Carlos Drummond de Andrade, Álvaro Moreyra, Aurora Jardim (jornalista e romancista portuguesa), Ruy de Carvalho (ator português), Deolindo Tavares (poeta e escritor pernambucano), Walter e Ruth (desconhecidos).

DOSSIE VIDA RELIGIOSA - 1915 e 1931 (2 documentos)

Santinho da primeira comunhão de Sylvia Chalreo (1915) e oração datilografada para Santa Rita do Viterbo (anotação a mão: N, 25/08/1931).

DOCUMENTOS IDENTITÁRIOS e ASSOCIATIVOS - 1933 - 1965 (10 documentos)

Carteiras de associações profissionais e de identidade.

DOCUMENTOS AVULSOS

- Poema de Alfredo de Leon dedicado a Maria Tabacchi de Leon, 1888.

- Programa impresso Theatro Moulin Rouge, 1901.

- Redação escolar sobre Silvia - Patrícia Luz, sd.

- Diário de Silvia (manuscrito em agenda de 1989).

\section{VIDA PROFISSIONAL - ARTES VISUAIS}


Reúne documentos relativos à atividades de produção, difusão e comercialização da sua obra plástica, conservados em pastas e armazenados em uma mapoteca. Algumas pastas contêm a inscrição Sobre Silvia.

\section{CATÁLOGOS E CONVITES DE EXPOSIÇÕES}

- Exposições individuais de Silvia - 1945 - 1979 (26 documentos).

- Pastas Exposições coletivas no Brasil (duas) - 1970 - 1974.

- Avulsos: Catálogo da Feira de Arte Moderna promovida pela ABI e Liga da Defesa Nacional em 1943 e de outras exposições coletivas com a participação de Silvia (s/d).

COLEÇÃO DE LIVROS DE ARTE - 1927 - 1988 (62 livros)

Livros, enciclopédias e dicionários sobre artistas e arte brasileira e estrangeira. Alguns exemplares numerados e assinados.

COLEÇÃO DE OBRAS DE ARTE - décadas de 1930 a 1980 (cerca de 280 obras)

- Pinturas - aquarelas e óleos sobre tela de Augusto Rodrigues, Carlos Alberto Sorensen Durval Serra, Helvídia, Hilda Campofiorito, Ivonaldo, Luis Santos, Luis Soares, Meier Filho,Paiva Brasil, Naval, Quirino Campofiorito, Sheila, Sigaud.

- Gravuras: primeira série de 12 gravuras do Clube da Gravura do Rio de Janeiro (19521954), Abelardo da Hora, Babibinski, Carlos Fernandes, Darel, Emanuel Araújo, Gesa Heller Glauco Rodrigues, Inácio Rodrigues, Irlandini, Lígia Palombini, Neusa D’Arcanchy, Noeli de Paula, Quirino Campofiorito, Renina Katz, Rubens Trinaz Fox, Tenreiro, Walter Levy, Poty, Newton de Sá.

- Esculturas: cerca de 20 obras, sem identificação de autoria e data.

- Desenhos de Abel Salazar, Aldo Bonadei, Carlos Scliar, Clovis Graciano, Djanira, D. Ismalovicht, Darel, Dezon, Durval Serra, Eurídice, Glauco Rodrigues, Joana Lumermman, Noemi, Poty, Rubens Trinaz Fox, Sigaud e Quirino Campofiorito

\section{CORRESPONDÊNCIAS ARTES VISUAIS}

- Correspondência ativa - 1972 - 1980 (sete documentos): rascunhos e cópias de cartas enviadas para críticos de arte e museus. 
- Correspondência passiva - 1964 - 1990 - (80 documentos): cartas e ofícios recebidos de museus, galeristas e críticos de arte. Carta de agradecimento do assessor chefe de relações públicas do Ministério das Comunicações.

- Correspondência de terceiros - 1943 - 1991 (três documentos)

- Rascunho de carta de Oscar Meiosa apoiando a Feira de Arte Moderna e a luta antifacismo, 1943.

- Cópia de carta traduzida enviada pelo Vaticano para Ângelo Scheppis, 1970.

- Telegrama de pêsames pela morte de Silvia, enviado pelo presidente do Museu Internacional de Arte Naïf do Brasil, Lucien Filkestein, para Pedro Xavier, 1991.

\section{CURRÍCULOS ARTISTA - 1976 (quatro documentos)}

Currículo produzido em 1976, rascunhos e traduções para o inglês e italiano.

DIPLOMAS E HOMENAGENS - 1951 - 1985 (12 documentos)

Convites, diplomas e certificados emitidos por museus e personalidades políticas homenageando a obra de Silvia.

DOSSIÊ DE IMPRESSOS - 1945 - 1991 (62 documentos)

- Pastas Sobre Silvia - Recortes de jornais e revistas contendo anúncios, reportagens e críticas sobre exposições de Silvia.

- Pasta contendo xerox da matéria Art Naïf: il s'agit du bonher - Revista Le point 495 França, 1982.

- Pasta contendo xerox da matéria Naive art in Brazil, Sheldon Willians, in Historcal surveys of naive art in individual countries, sd.

- Pasta contendo xerox de matérias de jornal sobre exposição de Silvia na Galeria Adriana, Holanda, 1983.

- Edição número 100 da Gazette Galerie Pro arte.

\section{ENTREVISTAS}


Entrevistas com Silvia gravadas para os programas Fatos e Ideias, da Rádio Ministério da Educação, 1967; Mulheres inesquecíveis, 1973 e Guanabara em notícias, sd (suporte disco de vinil).

\section{FOTOGRAFIAS}

- Reproduções fotográficas das obras de Silvia - com anotação do nome dos compradores.

- Cobertura fotográfica

○ Cobertura fotográfica de Vernissages - 1960 - 1980 (26 álbuns). Algumas imagens com anotações identificando o evento e pessoas

- Cobertura fotográfica da Exposição em Homenagem ao servidor público, 1979.

- Retratos de Silvia em seu ateliê e em exposições, sd.

- Fotografias avulsas, conservadas em pastas. Imagens reproduzidas em reportagens sobre sua obra e em catálogos de exposições.

OBRAS DE SILVIA - 1940 - 1989 (256 documentos)

Ilustrações para discos e livros, desenhos, pinturas à óleo, escultura e gravuras de autoria de Silvia.

RECIBOS DE COMPRA DE MATERIAIS DE ARTES - 1980 - 1989

Recibos de compra de telas e molduras.

RECIBOS DE DOAÇÃO E VENDA DE OBRAS DE ARTE - 1979 - 1982 (cinco documentos). Recibos emitidos pelo Museu Nacional de Belas Artes, Galeria de Artes Jean Jacques e Funarte, contendo títulos e valores das obras.

\section{RELAÇÕES DE OBRAS EM MUSEUS E GALERIAS (cinco documentos):}

- Rascunho com relação de obras enviadas para Anatole Jakovsky, Museu Internacional de Arte Naïf, Nice, França, 1972.

- Rascunho com relação de obras enviadas para Anatole Jakovsky, Museu Internacional de Arte Naïf, Nice, França, 1978.

- Ficha de aquisição de obras - Museu Internacional de Arte Naïf, Nice, França, 1983 
- Rascunho contendo relação de obras enviadas para Sheldon Willians, sd.

- Cópia datilografada de obras enviadas para Galeria Funarte Sérgio Milliet, c. 1976.

DOSSIÊ GALERIA JEAN-JACQUES

- Uma pasta contendo catálogos, cartas convite da galeria e catálogos de mostras de outros artistas, década de 1980.

- Cinco pastas contendo catálogos, cartas convite, recibos de pagamento de obras e correspondência de Silvia.

- Uma pasta contendo catálogos, recibos de pagamento de obras e correspondência relativas à exposição individual de Silvia, 1984.

DOSSIÊ GALERIA CRAVO E CANELA

Uma pasta contendo catálogos, recibos de pagamento de obras e correspondência de Silvia, 1979.

DOSSIÊ ANATOLE JAKOVSKY - 1970 - 1980

Duas pastas contendo catálogos, cartas convite, recibos de pagamento de obras, cartas e cartões de natal.

LISTAS DE ASSINATURAS

- Lista de assinaturas dos artistas plásticos que contribuíram para uma Feira de Arte a favor da Força Aérea Brasileira.

- Convite para almoço em homenagem a Jorge Amado, com cardápio e assinaturas.

\section{VIDA PROFISSIONAL - LITERATURA E JORNALISMO}

- CORRESPONDÊNCIA (três documentos)

- Carta enviada pela Revista Brasil Feminino convidando Sylvia de Leon Chalreo para trabalhar como correspondente, 1932.

○ Bilhete do Gabinete do Ministério da Educação e Saúde para Silvia, assinado Carlos (Carlos Drummond de Andrade), 1945. 
- Ofício da Federação das Entidades Culturais Fronteiriças para Silvia, propondo a sua integração aos quadros sociais da instituição, 1981.

\section{CURRÍCULO JORNALISTA - (um documento)}

Relação das atividades de Silvia na imprensa de 1938 a 1976.

DOSSIÊ ACLERJ - 1978 - 1985 (45 documentos)

Convites, comunicados, circulares e estatuto da Academia de Letras do Estado do Rio de Janeiro (ACLERJ) e recortes de jornal sobre o tema.

DOSSIÊ ESFERA - 1938 - 1951

- Pastas Sobre Silvia contendo cartas, bilhetes, poemas e artigos manuscritos ou datilografados enviados para a Esfera por colaboradores.

- Coleção completa encadernada da Revista Esfera.

\section{DOSSIÊ TELEVISÃO}

- Matérias em jornais sobre o prêmio criado por Silvia quando responsável pela seção Telecrítica do programa Revista da Televisão da TV Continental, onde artistas plásticos ofereceram suas obras como prêmio para os melhores da televisão, 1962.

- Fotografias de Silvia no Telecrítica com Zora Seljan (O Globo), Almir Azevedo (O Semanário), Alamir Carvalho (Revista TV), Paulo Salgado (Revista Aconteceu), Walmir Ayala (Revista Leitura), sd.

REPORTAGENS E ARTIGOS DE SILVIA

Recortes de revistas e jornais contendo reportagens e artigos produzidos por Silvia e conservados em pastas.

- No mundo das Artes: France Dupaty, notável pintora; crítica de artes. Revista Rio Social, 1943.

- O cherie de Collete; crítica teatral; Revista Fon Fon, 1956.

- O teatro oficial em 1976; crítica teatral; Revista Fon Fon, 1957. 
- O terceiro congresso nacional de teatro, crítica teatral; Revista Fon Fon, 1957.

- Os melhores do ano em teatro; crítica teatral; Revista Fon Fon, 1957.

- Casamento entre artistas: Consuelo Leandro e Agildo Ribeiro; social; Revista Fon Fon, 1957.

- Conselho a um autor; crítica teatral; Jornal O Globo, 12/11/1958.

- Cinema Nacional; Revista Fon Fon, sd.

- Dois exemplares da Revista Rio Social - agosto e setembro de 1943.

\section{FOTOGRAFIAS}

- Reproduções fotográficas de obras de arte recebidas para publicação. No verso de algumas fotografias há medidas (para impressão), nome do autor e quadro e dimensões manuscritos. Em algumas com a letra de Silvia está escrito o nome do veículo e da coluna. A maioria foi recebida para divulgação no Jornal de Letras, coluna roteiro de artes e revista Para Todos. Há imagens de obras enviadas pela National Gallery of Art, Wasghinton e por outras instituições do exterior e fotos enviadas por artistas residentes nos EUA.

- Fotografia de Silvia em grupo; III Congresso internacional de críticos de arte, 1951.

- Fotografia da fachada do edifício sede do II Congresso de intelectuais de Goiânia, 1954. 


\section{2 - FEMINISMOS E FEMINISTAS}

A geração de Silvia foi herdeira da luta de mulheres que ousaram ocupar o espaço público, questionar e fazer diferente. Para a maioria das pessoas, até meados do século XX, e para muitas até hoje, doçura, espírito altruísta, espírito materno e sensibilidade eram atributos naturais das mulheres, excluindo a razão, considerada própria do sexo masculino. Assim justificava-se a submissão imposta ao sexo feminino e as funções destinadas às mulheres na sociedade. Esta imagem "construída para a mulher pela ideologia da domesticidade, legitimada pelas teorias evolucionistas e negadoras de suas capacidades físicas e intelectuais" (RAGO, 2001:5) estava introjetada no imaginário e nos hábitos de toda sociedade. Muitas que fugiram deste padrão foram consideradas doentes, pecadoras e criminosas e punidas com isolamento, remédios, castigos e, no caso de adultério, até com a morte ${ }^{10}$. Hoje em dia os altos índices de feminicídio e agressões físicas contra mulheres de todas as classes sociais no Brasil, seus menores salários e reduzida participação no mundo político, empresarial e financeiro, comprovam o quanto esta idealização da mulher burguesa naturalizou a violência e a discriminação.

Sabe-se muito pouco sobre as lutas travadas no decorrer de séculos para desconstruir este estereótipo, mas desde o início do século XIX no Brasil, apesar de muita resistência da sociedade e tendo muitas vezes que se esconder atrás de pseudônimos, escritoras e jornalistas contribuíram para esta desconstrução. A começar por Nísia Floresta (Papari/RN, 1810 - França, 1885), que em seus trabalhos defendia a educação das mulheres como a grande arma para a conquista de direitos sociais, civis e políticos, tendo criado a primeira escola para meninas que, além da costura, cuidados com o lar e boas maneiras, tinha em seu programa aulas de gramática, escrita e leitura do português, francês e italiano, ciências naturais e sociais, matemática, música e dança. Suas ideias e ações foram precursoras no Brasil e dominaram o discurso de quase todas as escritoras até o final do século XIX, que enfrentaram os preconceitos da sociedade patriarcal e mostraram na vida e na escrita que as mulheres eram intelectualmente tão capazes quanto os homens.

Entre as precursoras nas letras no Brasil: Ana Eurídice Eufrosina de Barrandas (1806 -?), Maria Josefa Barreto Ferreira Pinto (? - 1897) e Delfina Benigna da Cunha (1791 - 1857), que atuaram no Rio Grande do Sul e participaram ativamente da Revolução Farroupilha; Maria Firmina

\footnotetext{
${ }^{10}$ As ordenações Filipinas (1603), aplicada no Brasil colonial, previa a pena de morte para a adúltera e o amante. Só em 1940 o Código Penal deixou de fazer qualquer distinção ao gênero da pessoa que praticava o adultério, punindo homens e mulheres da mesma forma. A prática só deixou de ser crime no Direito Penal Brasileiro em 2005, apesar de que a doutrina já considerava anacrônica há tempos sua incriminação. (ICIZUKA, 2007).
} 
dos Reis (1822-1917), maranhense, negra, escreveu Úrsula, que hoje é considerado o primeiro romance de uma autora brasileira, foi professora, participou da imprensa, publicou livros, participou de antologias e lutou ativamente pela abolição da escravidão; Narcisa Amália de Campo (1852 1924), poeta nascida em São João da Barra, Rio de Janeiro, que “coloca sua pena à serviço de ideias democráticas e progressistas, da modernização das estruturas da nação e da elevação do nível cultural e material da população" (TELLES, 2005:419); a gaúcha Maria Benedicta Bormann (1853 - 1895), que utilizando o pseudônimo Délia, publicou romances e folhetins em jornais nas duas últimas décadas do século XIX falando de sexualidade, profissionalização e satisfação dos desejos femininos; Luciana de Abreu (Porto Alegre, 1847 - 1880), descendente de escravos, escritora, oradora, poeta e professora, tornou-se conhecida por escrever para jornais sobre as injustiças a que estava sujeito o sexo feminino; Júlia Lopes de Almeida (1862 - 1934), em "seus romances trata da cidade e do campo, dos costumes e do cotidiano, de cortiços e palacetes durante as últimas décadas do século XIX e início do século XX” e adquiriu prestígio como jornalista no Rio de Janeiro, tendo feito parte do corpo de redatores do periódico A Semana, junto com Olavo Bilac, Artur de Azevedo e Filinto de Almeida, seu marido e, por mais de trinta anos, escrito crônicas para o jornal O Paiz (Idem, 2005).

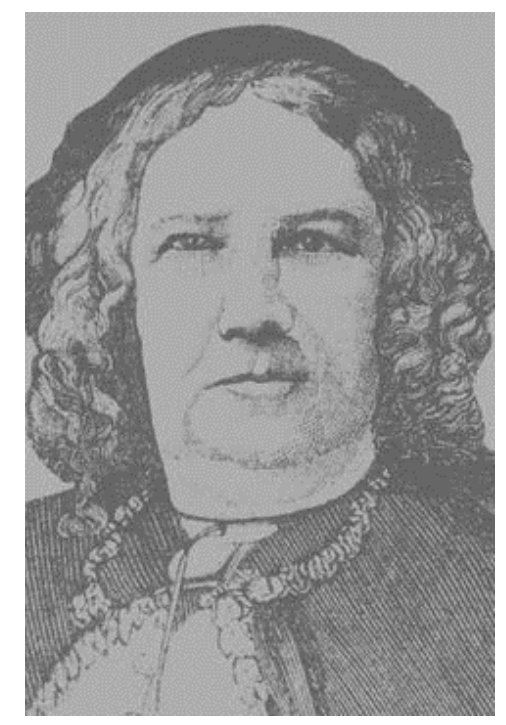

Figura 11 - Nísia Floresta, c. 1885. Fonte: Biblioteca Nacional, domínio público

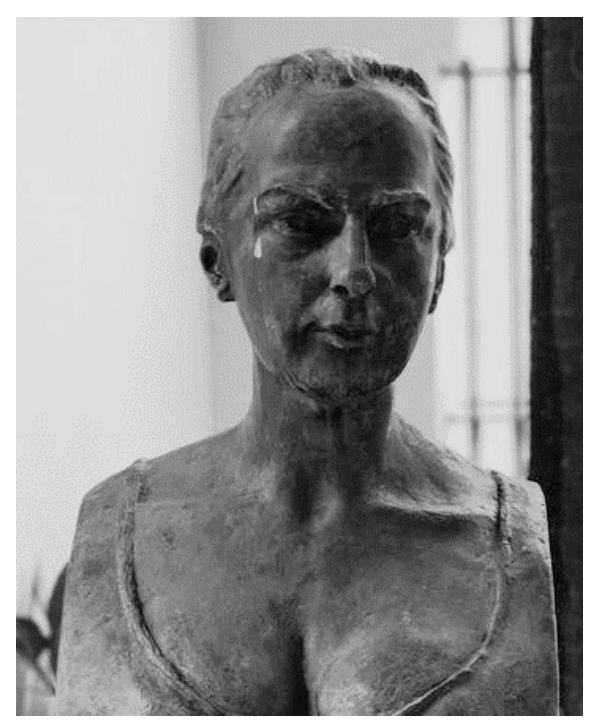

Figura 12 - Flory Gama, Busto de Maria Firmina dos Reis, 1976. Fonte: ARRAES, 2017 


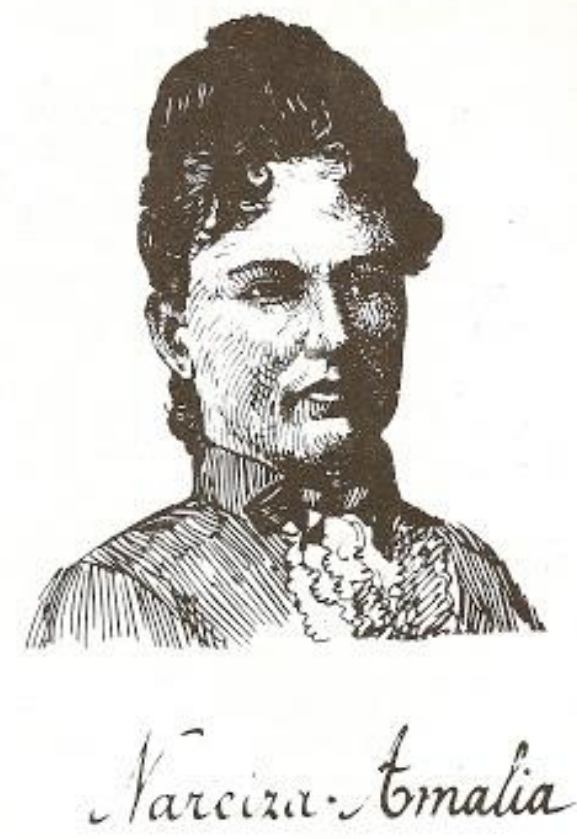

Figura 13 - M. J. Garnier, Retrato de Narcisa Amália c. 50 anos de idade, 1906. Bico de pena. Fonte: FENSKE, 2015, domínio público

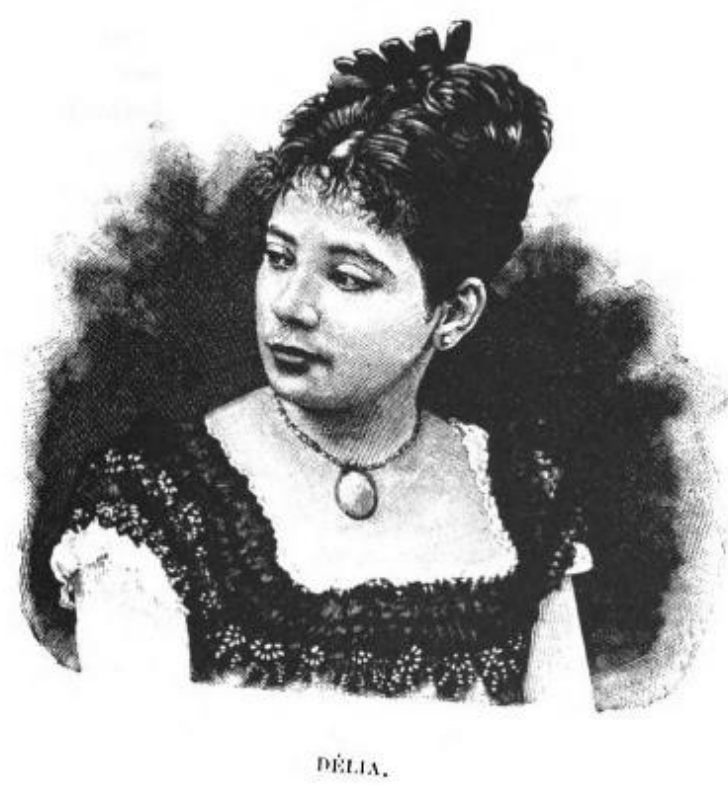

Figura 14 - Figura 13 - Retrato de Maria Benedita Câmara Bormann, c. 1899. Fonte: SABINO, [1899] 1996, domínio público 


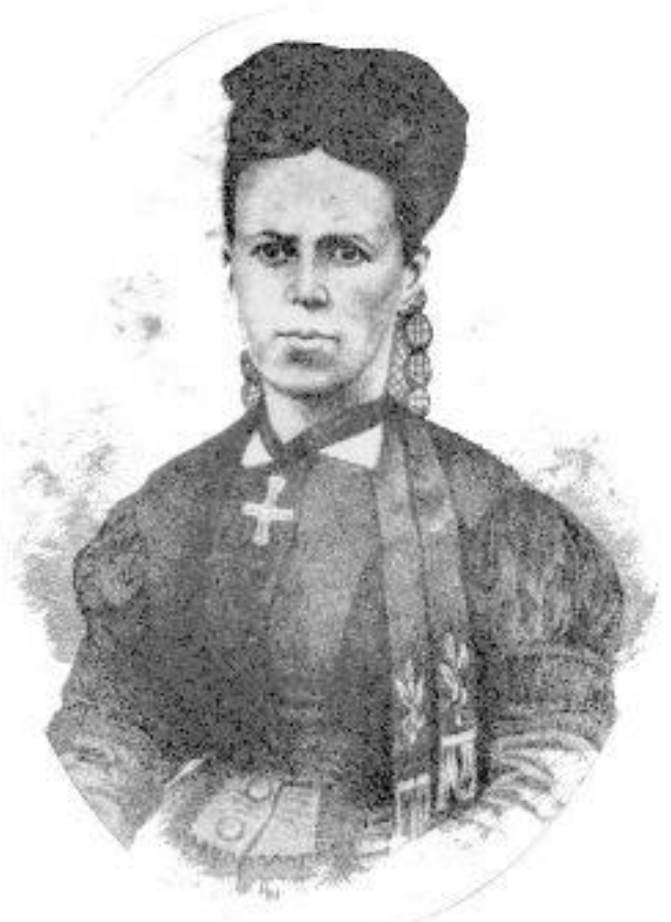

Figura 15 - J. Alves Leite, Luciana de Abreu, 1873. Litografia. Fonte: Wikimedia Commons, Museu Júlio de Castilhos, domínio público

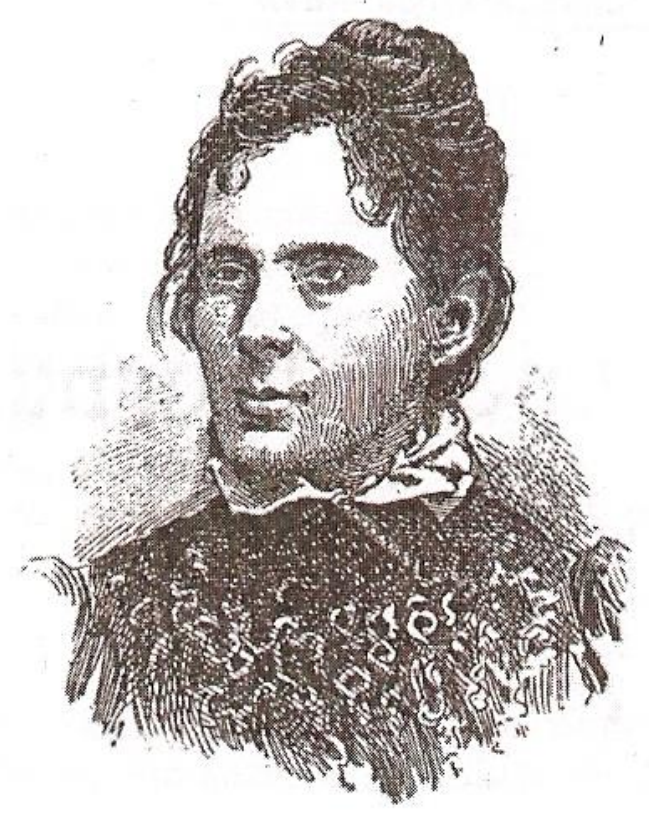

Figura 16 - Júlia Lopes de Almeida, 1903. Desenho da matéria de frente da primeira edição de Ância Eterna. Fonte: Wikimedia Commons, domínio público 
Estas são algumas, entre tantas outras brasileiras cujas trajetórias de vida têm muito a contar, que escreveram romances e publicaram ideias emancipatórias em livros, jornais e revistas e, principalmente a partir de meados do século XIX, em periódicos muitas vezes destinados especificamente ao público feminino ${ }^{11}$.

(...) desde a segunda metade do século XIX as revistas femininas representaram uma via de manifestação para intenções literárias silenciadas, principalmente entre escritoras de menor produção. Além de um espaço onde a movimentação intelectual se misturava com as ansiedades políticas por mais direitos e mais participação no espaço público, em algumas épocas haviam tantos periódicos dirigidos por mulheres, que chegaram a formar uma rede, de nortes a sul do Brasil. (RAMOS, 2016:1).

Nas primeiras décadas do século XX, impulsionados pelo movimento sufragista internacional iniciado no século XIX, proliferaram-se jornais, associações e movimentos feministas. As mudanças de comportamento das mulheres foram evidentes, com o uso de saias e cabelos curtos, maiôs, maquiagem nos cílios, sobrancelhas e lábios e no hábito de fumar em público e falar gírias. Uma mudança de costumes que caminhava ao lado da conscientização política, da tentativa de conquista da cidadania política e da busca do exercício de profissões até então restritas ao mundo masculino (PINHEIRO, 2007:62).

Foi a profissão de jornalista que Sylvia abraçou paralelamente ao funcionalismo público no início da década de 1930, período em que vivia entre Rio de Janeiro e Niterói, capital do Estado há mais de cem anos ${ }^{12}$.

A cidade tinha mais de 200 mil habitantes e em sua região central, que já era cortada por avenidas e bondes que a ligavam a bairros mais distantes, se convivia com o trânsito de automóveis cada vez mais intenso. Apesar das reformas urbanas realizadas durante a década de 1920, quando foram criados colégios, cinemas, áreas de lazer, balneários e cassinos, até o final da década de 1930 Niterói vivia um clima de provincianismo e de emulação da vida cultural do Distrito Federal. Era, no entanto, por sua condição de capital do Estado, um centro que reunia a intelectualidade fluminense e o destino de jovens e intelectuais do interior, que publicavam trabalhos literários e jornalísticos e se reuniam para discutir o cotidiano político e cultural da cidade e do País. Circulavam principalmente

\footnotetext{
${ }^{11}$ Sobre a contribuição destas e outras mulheres escritoras no século XIX ver: TELLES, 2005 e Mulheres século XIX, TRAVESSIA, ñ 23, Publicação do programa de Pós-Graduação em Literatura; Universidade Federal de Santa Catarina, Brasil; 1991.

${ }^{12}$ O Rio de Janeiro foi capital do Distrito Federal até a transferência do governo federal para Brasília, em 1961, quando passou a ser capital do Estado da Guanabara. Só com a fusão dos Estados da Guanabara e Rio de Janeiro em 1975, que deixou de ser a capital do Estado sendo substituída pela cidade do Rio de Janeiro.
} 
entre a Academia Fluminense de Letras, a sede do periódico A Revista e o Hotel e Café Paris. Este último estabelecimento, localizado em frente ao Mercado Municipal e à estação das barcas, de 1908 até o final da década de 1930 reuniu médicos, advogados, educadores, jornalistas, militares e funcionários públicos em uma roda literária, que ficou conhecida como Cenáculo Ambulante (CORTE, 2009).

Mais frequentes eram os saraus, reuniões intimas organizadas nas residências onde, segundo um dos participantes,

[...] Alcides Figueiredo, Raul de Sá Pinto, Luciano Gualberto, Alfredo Bahiense, Ulisses e Aniceto Medeiros, Eurípedes Ribeiro, Izidro Nunes, Guilherme Cruz, Avelar e Silva, Júlio Seabra e tantíssimos outros (...) sob a influência de um incontido desejo d'arte, enchiam as horas calmas duns versos cantantes, sentimentais, recitados com ênfase aos sorrisos das moças formosas de vestidos mais ou menos longos, e basta cabeleira flava, que não se furtavam aos aplausos à primavera de amor e de poesia em que se ostentavam vitoriosos, alguns jovens de talento (GONÇALVES, 1925 apud FERNANDES, 2014:10).

Os mais conhecidos representantes da intelectualidade fluminense na década de 1930 são do sexo masculino, mas o arquivo de Silvia nos mostra outras instituições culturais e educacionais onde as mulheres não eram apenas espectadoras, "moças formosas de vestidos mais ou menos longos, $e$ basta cabeleira flava”, mas criadoras, organizadoras e gerenciadoras.

Entre a formatura na Escola Normal (1922), entrada na prefeitura (1924) e o início da década de 1930, Sylvia começou a participar do mundo intelectual de Niterói, provavelmente frequentando estes saraus e rodas literárias e se envolvendo com as lutas pela emancipação feminina e conquista do voto pelas mulheres. Em 1928, sua ligação com este mundo já fica evidente quando o Jornal do Brasil cita seu nome como representante da prefeitura na comissão da Federação Brasileira pelo Progresso Feminino, que organizava uma recepção ao Presidente do Rio Grande do Norte, Juvenal Lamartine $^{13}$. A FBPF foi a segunda associação feminista do Brasil, criada em 1922. A primeira foi a Liga para a Emancipação Intelectual da Mulher, criada por Bertha Lutz em 1919.

Neste período, diferentes forças sociais e políticas se organizavam em associações e partidos políticos, se posicionando frente a questões sociais como pobreza, educação, saúde, direitos da mulher e direitos do trabalhador, acirradas pelo processo de urbanização e industrialização crescente (COSENZA, 2012). Foi neste contexto que um grupo de mulheres de Niterói lideradas por Sylvia, então uma jovem de 26 anos, resolveu criar uma associação feminista na cidade.

\footnotetext{
${ }^{13}$ Jornal do Brasil, 05/05/1928:9.
} 


\section{1 - Athénée, um clube feminista em Niterói}

Em uma das pastas Sobre Silvia há um conjunto de documentos de 1931, os mais antigos que informam sua participação no espaço público. São recortes de jornal e fotografias sobre a fundação do Athénée Club e do Escritório de Ligação Feminina Geral e Estudos Sociais de Niterói.

O nome do clube, grafado em francês, representando a valorização da cultura erudita europeia, tinha em seus estatutos os seguintes objetivos:

\footnotetext{
Oferecer à intelectualidade feminina um ambiente propício ao desenvolvimento e disseminação da cultura: seja física, para o aperfeiçoamento da saúde; literária ou científica, para maior elevação espiritual, congregando idealismo e realismo como única e verdadeira concepção de vida. ${ }^{14}$
}

O Athénée se dirigia à intelectualidade, uma parcela mínima do universo feminino, abrindo espaço para disseminação da literatura e ciências sociais entre as mulheres da alta sociedade de Niterói. A diretoria do clube, que tinha Sylvia na presidência, era formada por Manoelita Paraná, secretária, colega de Sylvia na prefeitura; Guiomar Silveira, tesoureira, e Angelita Leon da Silveira, bibliotecária. Sua inauguração aconteceu no Palacete Kastrup, sede do Automóvel Clube de Niterói e foi divulgada em jornais e revistas das duas capitais vizinhas.

Os clubes se proliferaram na década de 1930, agregando pessoas da alta burguesia com interesses semelhantes, promovendo todo tipo de comemorações sociais com grandes festas e muita ostentação, funcionando como espaços tanto de sociabilização quanto de segregação social, facilitando a manutenção de privilégios, a circulação do dinheiro entre as mesmas pessoas e os casamentos entre as famílias ricas. O Automóvel Clube de Niterói, fundado aos moldes Automóvel Clube do Brasil com sede no Rio de Janeiro, além de excursões automobilísticas pelo Estado promoveu em suas luxuosas instalações festas, bailes de carnaval, ano novo, formaturas e outras atividades sociais, como a sessão de arte realizada na inauguração do Athénée.

Foi chamada de A Hora da Arte, um nome que se repete em diferentes eventos artísticos realizados no período. Neste dia, uma plateia composta por homens e mulheres vestidos elegantemente, que segundo o jornal Diário Carioca faziam parte da alta sociedade de Niterói e Rio de Janeiro, assistiu à palestra de abertura do advogado Ramon Benito Alonso, que apresentou a instituição como sendo resultado do esforço de "gentilíssimas senhoras e feministas entusiastas

\footnotetext{
${ }^{14}$ Diário da Noite, Rio de Janeiro, 15/08/1931.
} 
pertencentes à alta sociedade niteroiense ${ }^{15 "}$, seguida por uma sessão de música com a participação de Mário de Azevedo (piano), Antonietta de Souza (canto), Licínio Morrison (piano) e Iberê Gomes Grosso (violoncelo) e de poesias, com apresentações de Walfrido Faria, Eduardo Tourinho, Anna Amélia Carneiro de Mendonça e Aracy Faria.

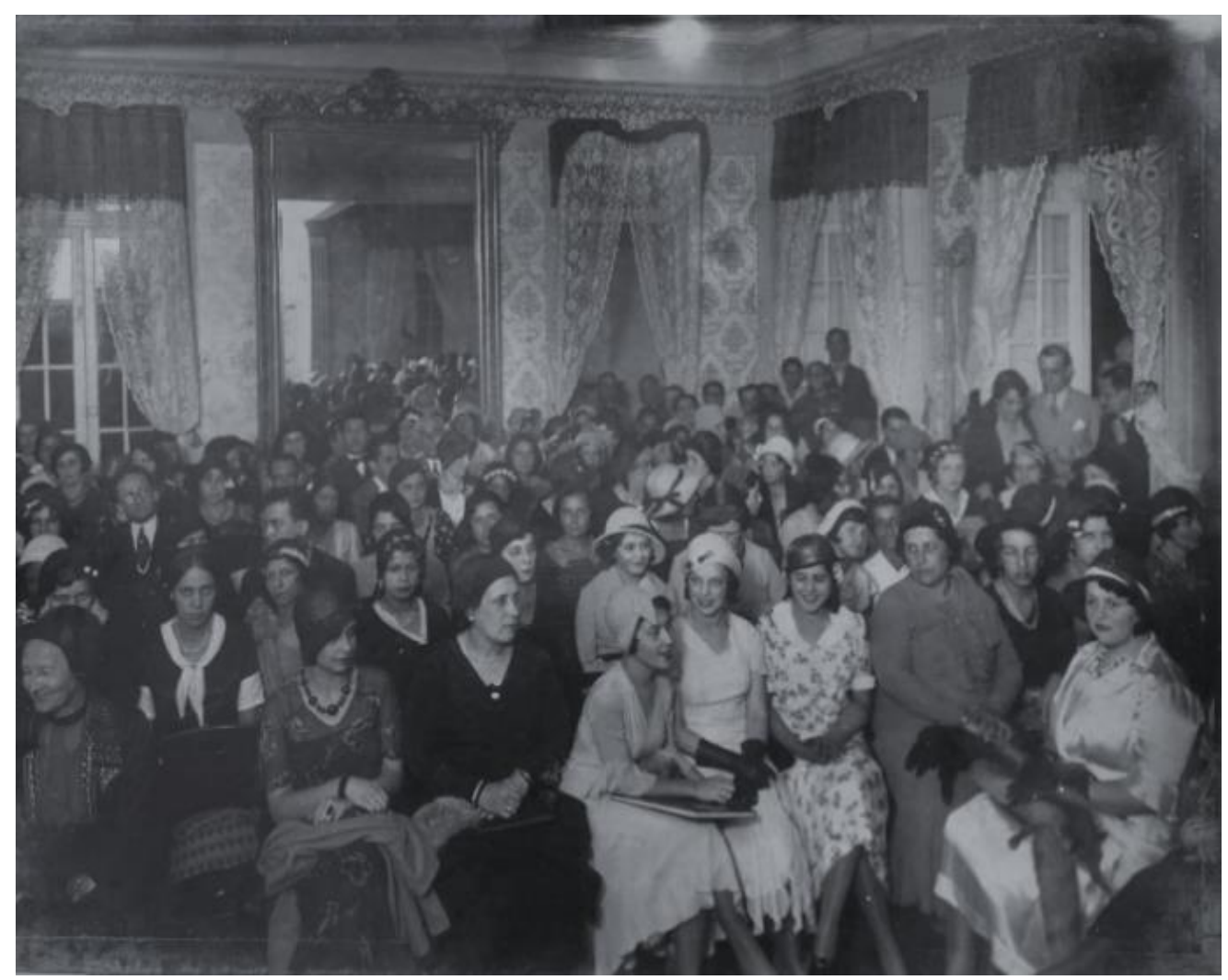

Figura 17 - Plateia do evento Hora da Arte, Athénée Clube, 1931. Fonte: Arquivo Silvia

Os músicos tinham em comum a formação erudita e a participação em um momento renovador do mundo musical brasileiro, quando a busca pela música genuinamente brasileira entrava pelas portas da Academia, a radiodifusão começava a se popularizar e adquirir um perfil mais comercial e a indústria fonográfica se expandia (VALENÇA, 2014).

A grande estrela da seção musical foi sem dúvida a cantora Antonietta de Souza (1893 - 1976), que aos trinta e oito anos de idade já era famosa por seus recitais em companhias líricas e concertos no Brasil e países da Europa e também pelo trabalho como crítica musical, que publicava em jornais de grande circulação no Rio de Janeiro, entre eles o Diário da Noite e A Noite. Aluna e posteriormente professora atuante no Instituto Nacional de Música, participou da equipe de Luciano Gallet e Mário

\footnotetext{
${ }^{15}$ Diário de Notícias, Rio de Janeiro, 14/08/1931.
} 
de Andrade durante a reforma do ensino oficial de música realizada na instituição, que propunha uma didática compatível com os ideais modernistas. Foi também uma das criadoras da Associação Brasileira de Música e presidente do seu conselho deliberativo. O comentário abaixo, sobre a audição realizada no terceiro aniversário da instituição ilustra sua posição na época frente ao movimento de valorização dos elementos da cultura brasileira no mundo da música:

A ABM apresentou um novo gênero de música da nossa literatura musical, isto é, fez ouvir a primeira audição para o público carioca de um recitativo musical em português (...). Fiel ao pacto que fizemos com nosso consócio fundador, Luciano Gallet, de sempre nos alhearmos das nossas pessoas para, unidos, só trabalharmos por um ideal - o engrandecimento da música no Brasil - não poderíamos perder a oportunidade de prestigiar um acontecimento artístico que baliza uma efeméride notável da vida social dessa sociedade e que também se reflete no cenário artístico da nossa terra. ${ }^{16}$

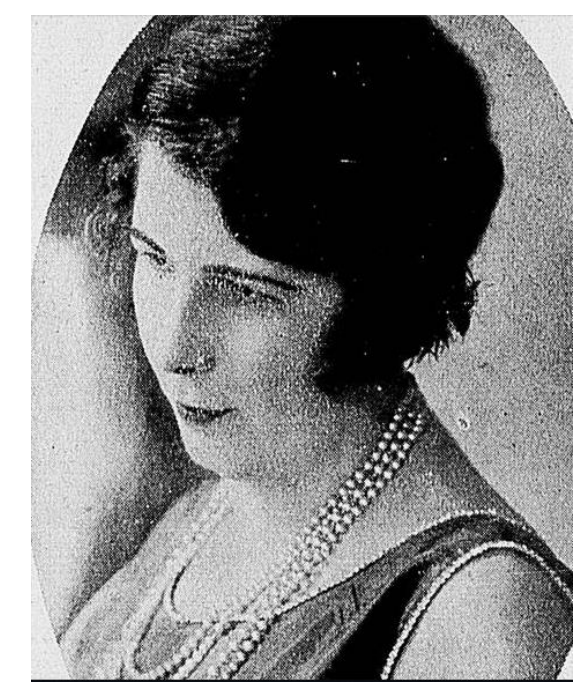

Figura 18 - Antonieta de Souza, c. 1930. Fonte: Revista da Semana, 27/09/1930

Outra atração foi o jovem e já prestigiado violoncelista Iberê Gomes Grosso, ex-aluno da Escola Normal de Música de Paris. Na data da inauguração do Athénée, aos vinte e seis anos de idade, já tinha contato com a vanguarda do modernismo musical: foi neste ano que o paulista Mozart Camargo Guarnieri, dois anos mais velho e pupilo de Mário de Andrade, lhe dedicou sua primeira sonata para violoncelo (RABELO, 1996).

${ }^{16}$ SOUZA, Antonieta. Concerto de aniversário da A. B. M. e primeira conferência de sua série de 1933, Música, A Noite, Rio de Janeiro, 07/07/1933. 
Os outros dois músicos, os pianistas Licínio Morrison e Mário de Azevedo, também participaram deste momento renovador, mas são menos conhecidos. Para sobreviver com a música exerceram diferentes funções neste mundo que se diversificava: além de acompanhar os recitais e saraus promovidos no Parque Lage pela famosa cantora de ópera Gabriela Besanzoni, Mário de Azevedo, ainda no início de carreira, atuava como demonstrador de partituras para casas de música no Rio de Janeiro e Licínio tocava nas programações de música de câmara e teatral das rádios Sociedade e Mayrink da Veiga e era professor de piano (se estabeleceu futuramente como funcionário público federal).

A terceira parte do programa, dedicada à poesia, também teve uma mulher como principal atração. Anna Amélia Carneiro de Mendonça tinha trinta e cinco anos de idade e desde o final da década de 1920 publicava poemas e artigos na imprensa, traduzia livros do alemão, inglês e francês e dava conferências em conceituadas instituições culturais ${ }^{17}$. Nesta época já tinha publicado os livros Esperança, recordações de infância (1911), Alma, (1922) e Ansiedade (1926). Casada com o popular Marcos Carneiro de Mendonça, jogador da Seleção Brasileira de Futebol, promovia em sua residência saraus que contavam com a presença de políticos influentes, intelectuais e artistas. Ativista e fundadora da Federação Brasileira pelo Progresso Feminino ao lado de Bertha Lutz, já era reconhecida pelo seu envolvimento com as lutas pela emancipação feminina, com atuação voltada para a questão sufragista, da saúde e da participação da mulher na política. Era também presidente da Casa do Estudante do Brasil, entidade que havia ajudado a criar há dois anos (1929), que atuava na assistência social e promoção, difusão e intercâmbio de obras e atividades culturais entre estudantes.

Aracy Faria também era atuante na militância feminista: fazia parte do conselho do Departamento Fluminense da Aliança Nacional de Mulheres, organização recém criada (1931), que cresceu rapidamente, chegando a contar com cerca de três mil associadas, pois se envolveu nos círculos operários do Rio de Janeiro e Minas Gerais prestando serviços de assistência jurídica à mulher trabalhadora e mantendo uma caixa de auxílio à mulher desamparada ${ }^{18}$. Era também uma bela mulher aos olhos da época, já que foi candidata a Miss Niterói em 1930. Jovem e bem relacionada declamava em saraus e recitais realizados no Teatro Municipal de Niterói, no Clube Central, em festas beneficentes e em residências niteroienses e cariocas.

A programação completa do evento de inauguração do Athenée não foi preservada, apenas os nomes dos participantes ficaram registrados nos jornais, que o divulgou em ambas as cidades. No

\footnotetext{
${ }^{17}$ A conferência Prosadoras e poetisas brasileiras, realizada por ela no IHGB em 1930 está publicada online na Revista do IHGB: <https://drive.google.com/file/d/0B_G9pg7CxKSsLU1OMDR6VVJTTGs/view〉. Acesso em 18/02/2019.

${ }^{18}$ Correio da Manhã, 20/2/31.
} 
Diário de Notícias, uma matéria com foto e entrevista de Sylvia anunciou o evento e, dias depois, o mesmo jornal veiculou uma chamada para a inauguração do clube ressaltando a participação das déesses Anna Amélia e Antonietta de Souza ${ }^{19}$. O Diário Carioca publicou três matérias: uma chamada no dia da inauguração, no dia seguinte um quarto de página com uma foto do grupo de participantes e programa resumido e no dia 15 de agosto, um texto de apresentação e a programação mais detalhada. O Fluminense, Jornal do Comércio, O Jornal, Correio da Manhã, A batalha, A Noite e Jornal do Brasil também o divulgaram em suas páginas. O Jornal do Brasil ressaltou que Sylvia era um nome conhecido em Niterói e no Rio de Janeiro, "pelo espírito culto e devotado à causa do feminismo".

As fotografias de Sylvia na inauguração do Athénée e a que ela mandou para os jornais para divulgar o evento representam uma tensão entre o modo como ela efetivamente se vestiu para a festa e a ousadia dos ombros nus e cabelos a la garçonne na foto utilizada na divulgação do evento, revelando duas Sylvias:

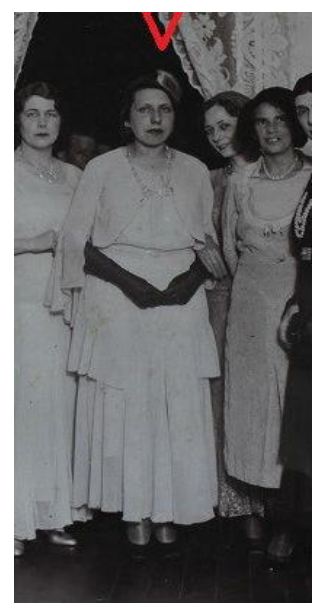

Figura 19 - Á esquerda, Sylvia na inauguração do Athéne, 1931. Fonte: Arquivo Silvia

Figura 20 - À direita, Sylvia de Leon Chalreo, c. 1931.

Fotografia utilizada na divulgação Athénée. Fonte: Arquivo Silvia

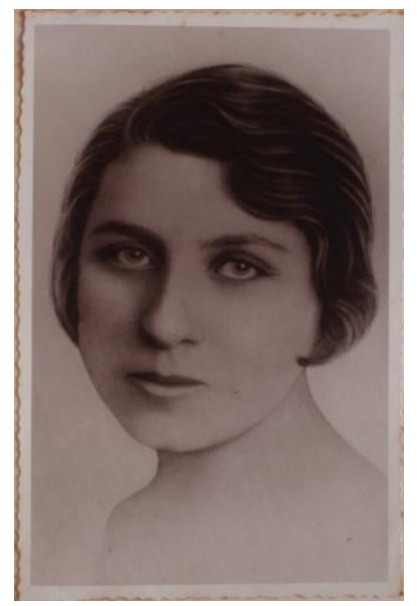

Em onze de novembro de 1931, o Jornal do Brasil e o Correio da Manhã anunciaram outro evento promovido pelo Athénée, Noite Brasileira de Música e Poesia, onde se apresentaram Olga Praguer, canto e violão, Sylvia Mello, com canto regional de Hekel Tavares ${ }^{20}$, Eugênia Álvaro Moreyra, Eduardo Tourinho, Waldo Abreu e Catulo da Paixão Cearense.

Olga Praguer Coelho tinha vinte e dois anos e era aluna da cantora lírica italiana, Gabriela Besanzoni, que dava aulas no Rio de Janeiro, quando escondida do pai começou a estudar violão. O instrumento não era considerado apropriado para mulheres, mas os costumes estavam mudando e logo conseguiu a aprovação para ter aulas com Patrício Teixeira, na época um violonista com carreira

\footnotetext{
${ }^{19}$ Diário de notícias, Rio de Janeiro, 28/07/1931 e 13/08/1931.

${ }^{20}$ Sobre Hekel Tavares: SILVA, Samuel Almeida. Reflections about Hekel Tavares and his song. 2009. Dissertação (Mestrado em Linguística, Letras e Artes); Universidade Federal de Goiás, Goiânia, 2009.
} 
consolidada, envolvido com o repertório do samba e professor de música na sociedade carioca (BENZECRY, 2015).

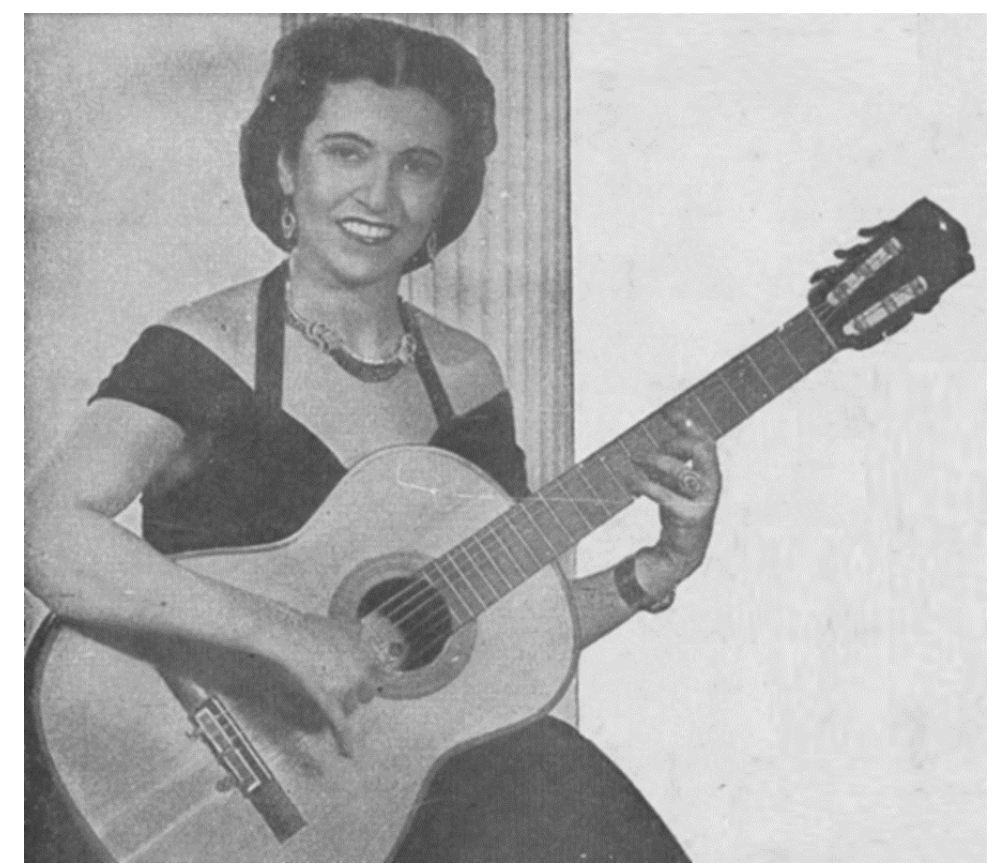

Figura 21 - Olga Praguer Coelho, 1943. Fonte:Wikimedia Commons, domínio público

Na inauguração do Athénée já era conhecida no Rio de Janeiro e tinha quatro discos gravados: no primeiro (Odeon,1929), cantou a embolada A mosca na moça e o samba Sá querida, acompanhada pelos violões de Patrício e Rogério Guimarães (Canhoto); nos outros três gravados em 1930, se destacam os motivos populares Puntinho branco, com versos de Olegário Mariano, Morena, com versos de Guerra Junqueiro e a canção Vestidinho novo, de Joubert de Carvalho. Já circulava, portanto, entre os famosos músicos que tocavam nas rádios do Rio de Janeiro. Poucos anos depois se tornaria uma artista internacional.

Sylvia Mello, que ficou conhecida como Bonequinha de feltro, nasceu em Pernambuco, em 1914 e chegou ao Rio de Janeiro aos nove anos de idade. Era uma garota ainda quando participou do evento do Athénée: com apenas 18 anos de idade, iniciava uma carreira que também a tornou reconhecida internacionalmente. Seu primeiro disco, com interpretação de Chove Chuva, de Hekel Tavares e Ascenso Ferreira e o Pequeno Vendedor De Amendoim, de Joracy Camargo e Hekel Tavares, foi lançado um mês após o evento, em dezembro de $1931^{21}$.

21 DICIONÁRIO Cravo Albin da Música Popular Brasileira. Sylvinha Mello. Disponível em: <http://dicionariompb.com.br/sylvinha-mello/dados-artisticos>. Acesso em 09/07/2018. 
Eugênia Álvaro Moreyra ${ }^{22}$ desde os 16 anos circulava na noite carioca e se destacava pela irreverência e ousadia no modo de agir, vestir e se comportar. Sete anos mais velha que Sylvia, na data da inauguração do Athénée sua interpretação da poesia moderna brasileira já era conhecida em São Paulo e no Rio de Janeiro: esteve presente na Semana de Arte Moderna de 1922 junto com seu marido, o poeta Álvaro Moreyra ${ }^{23}$, se relacionava e havia sido citada em obras e textos de modernistas consagrados como Mário de Andrade, Di Cavalcanti, Tarsila do Amaral, Manuel Bandeira e Oswald de Andrade ${ }^{24}$. Em uma das páginas da revista Para Todos, por exemplo, a ilustração de um poema de Oswald feita por Tarsila é dedicada à Eugênia Álvaro Moreyra ${ }^{25}$.

Neste ano estava finalizando um longo período de viagens pelo interior e periferias do Rio de Janeiro encenando textos de autores modernos europeus pelo Teatro de Brinquedo, grupo teatral criado por ela e Álvaro em 1927, vanguarda nas artes cênicas no País, agradando plateias e sofrendo a resistência da crítica conservadora, como observa o jornalista da revista Beira Mar:

\begin{abstract}
Possuindo uma biblioteca preciosa sobre o assunto, acompanhando o teatro nas suas mais recentes manifestações, conhecendo-lhes os últimos pronunciamentos nos grandes centros de cultura, estando a par mesmo do que tem havido ultimamente no domínio desta arte até na Rússia e no Japão, o casal [Eugênia e Álvaro Moreyra] lançou entre nós um teatro de feição moderna, seguindo o que na Europa por último tem se realizado: o Teatro de brinquedo. Com a aceitação do público e o aplauso das plateias do Rio e de São Paulo, teve entretanto a indiferença dos chamados críticos teatrais. ${ }^{26}$
\end{abstract}

Sua presença era constante em eventos culturais cariocas e paulistanos. Três anos antes da inauguração do Athénée se apresentou no Instituto Nacional de Música e no Teatro Municipal de São Paulo interpretando um programa que reunia autores modernistas ${ }^{27}$. Mário de Andrade, depois de assistir a este espetáculo escreveu sobre ela na revista Para todos:

\footnotetext{
${ }^{22}$ A biografia de Eugênia Álvaro Moreyra vem sendo pesquisada desde 2017 pela historiadora e roteirista Isabella Poppe, com o apoio do Programa Rumos Itau Cultural. O arquivo pessoal de Àlvaro Moreyra e Eugênia pertencem à Fundação Casa Rio Barbosa, Rio de Janeiro.

${ }^{23}$ Casaram-se em 1914 e viveram juntos até ela falecer, aos 50 anos, em 1948.

${ }^{24}$ O Malho, Rio de Janeiro, 30/07/1928, 38 e Para Todos, edição 00490, 1928:21.

${ }^{25}$ Para todos, Rio de Janeiro, 12/01/1929:22.

${ }^{26}$ Beira Mar, Rio de Janeiro, 01/10/1932:3.

27 Menotti Del Picchia, A Inauguração; Raul Bopp, Negro; Guilherme de Almeida, Tarde; Ascenso Ferreira, A Cavalhada; Emílio Moura, A minha Noite Sertaneja; Mário de Andrade, Acalanto do Seringueiro; Fernando Mendes de Almeida, Canção da Carestia da Vida; Felippe de Oliveira, Recuo Nostálgico; Manuel Bandeira, Evocação do Recife; Oswald de Andrade, Balada do Esplanada; Augusto Meyer, Irmã Água; Ribeiro Couto, Cinema de Arrabalde; Affonso Arinos Sobrinho, Lundu; Paulo Mendes de Almeida, Cabaret; Rosário Fusco, Sala de Gente Pobre; Jorge Salis Goulart, Brasil; Álvaro Moreyra, Visita de São Tomé, Estilização, Brasil Fidalgo, História, Bugre Velho, Carnaval, Preto Velho, Minha Terra e Oração. In: Para Todos, edição 00490; 1928:21. Hemeroteca Digital Brasileira.
} 
Tudo o que o poema revela, quem sabe ler, percebe no verso impresso. E percebe também quando Eugênia Álvaro Moreyra fala. Ela não interpreta, não. Deus a livre de declamar! Ela não interpreta, em vez, se limita a revelar o poema. ${ }^{28}$

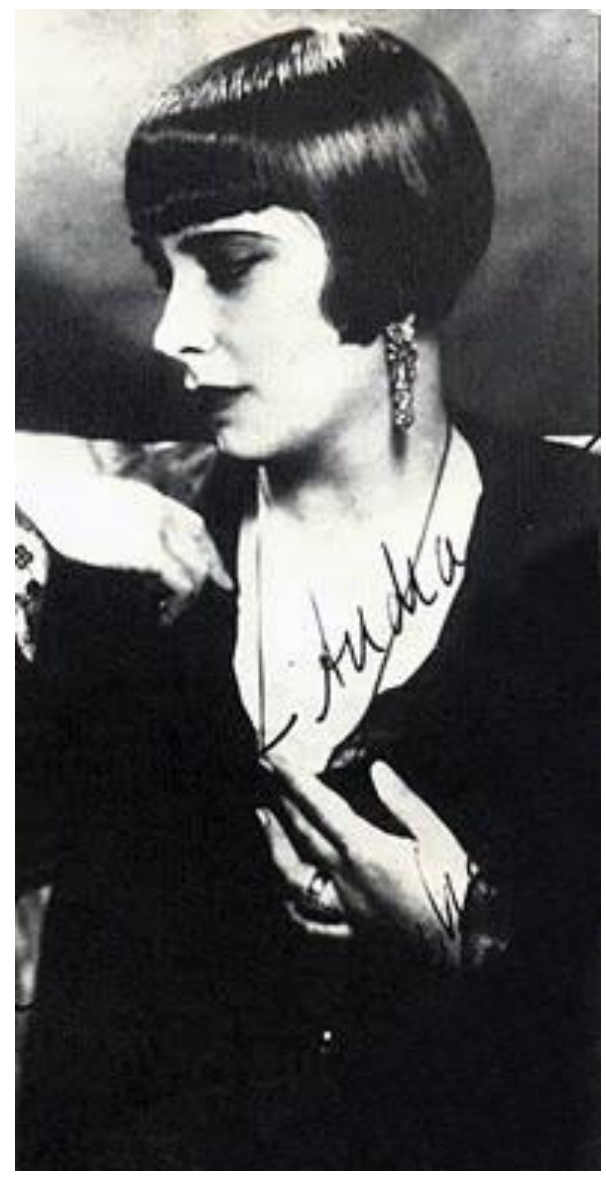

Figura 22- Eugênia Álvaro Moreyra, c. 1929. Fotografia. Fonte: Diário de Notícias, 26/05/1929

E também no artigo sobre a interpretação de sua poesia Toada para Você2 ${ }^{29}$ :

Eu gosto bem que musiquem versos meus, não tem dúvida. A vaidade é um fato. Só não gosto é que digam versos meus. Isso tenho horror, palavra. Só mesmo dona Eugênia Álvaro Moreyra valoriza a poesia da gente, porque ela foi artista suficiente para deixar o verso cantar por si, ruim ou bom. As outras recitadoras cantam... por si, não é o verso que canta mais não. Até foi matutando sobre estes pavores que inventei uma *fórmula digna do marechal Floriano: "Verso é verso, diseuse é diseuse. ${ }^{30}$

28 Para Todos, edição 00490; 1928:21. Hemeroteca Digital Brasileira.

${ }^{29}$ FERNANDEZ, Lorenzo (Composição), ANDRADE, Mário (poesia). Toda para você, Ed. Bevilaqua, Rio de Janeiro.

${ }^{30}$ Para Todos; edição 00522; 1928:16. 
A historiadora Isabela Poppe acredita que parte do esquecimento em relação a sua figura "possa ser atribuído à sua militância política, como acontece com diversos artistas que se engajam politicamente e acabam sendo rotulados como 'menores' ou como alguém que perdeu o rumo"31, mas outros fatores certamente contribuíram para este esquecimento: além da sua morte prematura aos cinquenta anos, a memória da esposa de um homem artista é na maioria das vezes registrada com um papel secundário. Como no texto a seguir, muitas referências a ela em periódicos a tratavam como $a$ esposa do poeta Álvaro Moreyra, o que também colaborou para este esquecimento:

A senhora Eugênia é um espírito inquieto, dinâmico, é o outro polo - do qual necessita o poeta, para a centelha que dá esplendor e colorido a sua arte. ${ }^{32}$

Catulo da Paixão Cearense, Eduardo Tourinho e Waldo Abreu, foram os representantes masculinos que se apresentaram no evento Noite Brasileira de Música e Poesia do clube feminista de Niterói. Waldo foi compositor popular e desde 1930 dirigia o programa radiofônico Esplêndido Programa na Rádio Mayrinque Veiga e Eduardo Tourinho (1896-1981) foi jornalista, poeta, tradutor e escritor e teve seus poemas musicados por compositores populares.

Catulo da Paixão Cearense tinha 68 anos e há muitas décadas já gozava de grande popularidade como criador de modinhas e poemas sertanejos. Além disso, foi um dos responsáveis pela introdução do violão na tradicional Academia Nacional de Música, ainda na primeira década do século. Segundo Mário de Andrade, ele se tornou um "poeta admirável" na "imitação da dicção e sentir do homem rural de uma região", "certamente o maior criador de imagens da poesia brasileira" ${ }^{\prime 3}$.

Tanto o evento A Hora da Arte quanto Noite Brasileira foram provavelmente financiados pela contribuição das associadas e contaram com suas relações com a elite local. Neste início dos anos 1930, com o desenvolvimento da radiodifusão, a música começou a atingir mais e mais pessoas e a rádio, a academia e os espaços da boemia eram os pontos onde se encontravam e dialogaram diferentes representantes da cultura no Rio de Janeiro. Muitos dos participantes eram professores do Instituto Nacional de Música e/ou circulavam nas rodas boêmias do Rio de Janeiro.

31 RIBEIRO, D. Eugênia Moreyra: revolucionária do início ao fim. Disponível em: <http://www.itaucultural.org.br/rumos-2015-2016-eugenia-moreyra-revolucionaria-do-inicio-ao-fim>. Acesso em $10 / 07 / 2018$.

${ }^{32}$ Para Todos; edição 00522; 1928:16.

${ }^{33}$ Diário Nacional, São Paulo; 20/12/1932. 
Apesar da ausência da programação em ambos os eventos, podemos acreditar que os artistas tenham apresentado o que faziam em outros eventos do mesmo período. Para exemplificar, poucos meses após a inauguração do Athénée, no programa A Hora do Riso, promovido no Teatro João Caetano no Rio de Janeiro, contracenaram entre outros artistas Aracy de Faria, Anna Amélia e Eugênia Moreyra. Numa matéria publicada sobre A Hora do Riso, o jornalista ressalta a representação da cultura popular e africana na encenação:

A cena de Macumba interpretada pela senhorita Eugênia Moreyra, com Simoens da Silva e “gente do morro", vão fazer ruidoso sucesso pela novidade, pelos cantos e pelas batucadas. Os "Paes de santo" vão marcar um novo gênero de palco. Serão levados - "O Corvo", de Álvaro Moreyra, "Por um fio", de Lamartine Babo e "A voz do apito", de Paulo Mac Dowell. ${ }^{34}$

O violão, a canção popular e a arte dramática são expressões do caráter vanguardista e libertador destas mulheres, tanto em relação à opressão vivida por suas contemporâneas, quanto em relação ao mundo das artes, onde atuavam na pesquisa e interpretação de canções e textos folclóricos e populares.

\section{2 - Escritório de Ligação Feminina Geral e Estudos Sociais de Niterói}

Em 1932, Sylvia participou da criação do Escritório de Ligação Feminina Geral e Estudos Sociais de Niterói junto a dezenas de mulheres. Enquanto o Athénée se voltou a atividades sociais e artísticas, o Escritório operava na área da educação, ciências sociais e política.

Como sabido, a educação foi o campo que as feministas, desde Nísia Floresta, atuaram intensivamente, pois viam como fundamental para seus objetivos emancipatórios. A instituição agia nesta área, mas trazia um novo interesse: o estudo pelas mulheres de questões sociais e políticas, se engajando no grande debate nacional instaurado com o golpe de estado de 1930.

$\mathrm{O}$ ano da fundação do ELFGCS foi marcado pela conquista do voto feminino e por um dos maiores conflitos armados da história do País, a guerra civil no Estado de São Paulo pela deposição de Getúlio Vargas e convocação da Assembleia Constituinte, mas a instituição se propunha a trabalhar com as questões políticas sem se alinhar a nenhum partido especificamente. Esta preocupação por si só indica a importância deste debate para elas e as divergentes posições partidárias das participantes,

\footnotetext{
${ }^{34}$ A Noite, Rio de Janeiro, 02/12/1931, $2^{\mathrm{a}}$ edição:4.
} 
o que fica explícito pela divulgação do trecho abaixo de seu estatuto no Jornal O Fluminense de Niterói:

O Escritório de Ligação Feminina Geral e Estudos Sociais, como observador e colecionador de fatos sociais estudará cívica e cientificamente todas as questões, mesmo partidárias, mas defende desde já a sua coesão social estabelecendo que nenhum de seus membros poderá usar do nome desta instituição nos assuntos partidários ou que admitam controvérsia, salvo se for autorizado por pelo menos dois terços da diretoria central. ${ }^{35}$

O Escritório era formado por um órgão deliberativo, a Diretoria Central, Administração e Departamento Social, presidido por Sylvia e tendo a dentista Margarida Grilo Jordão como vicepresidente. A diretoria central no ato de sua criação era composta pelas médicas Alzira Reis Vieira Ferreira (Minas Novas, 1886 - Niterói, 1970), Ermelinda Lopes de Vasconcelos (Porto Alegre, 1866 - Niterói, 1952), Hilda Neumann Koehler e as professoras Guiomar Souto de Avelar (diretora do Grupo Escolar José Bonifácio), Anna Lopes Trovão dos Santos e Maria Jacintha Trovão de Campos (Cantagalo, 1906 - Niterói, 1994), entre outras ${ }^{36}$.

Entre as sócias fundadoras estavam Cecília de Azevedo, Catharina Lima, Zeny Valente, Déa Judice de Mello, Zoé Judice de Mello, Stella Trovão de Mello, Ana Maria Garcia e Lydia Senna Campos. Quase todas eram professoras em Niterói ligadas à luta pela emancipação feminina. A atuação de Alzira Reis Vieira Ferreira, Ermelinda Lopes Vasconcelos e Maria Jacintha Trovão são as menos esquecidas: Alzira por ter sido a primeira mulher a votar no País, Ermelinda foi a primeira médica formada no Rio de Janeiro e Maria Jacintha pela trajetória de dramaturga que construiu a partir do final da década de 1930. No entanto, a atuação desta rede de mulheres na educação e saúde da mulher representada nesta e em outras associações também ficou esquecida.

Alzira era de uma família de políticos de Minas Gerais, o que lhe facilitou o acesso aos estudos, aos livros e as ideias modernas que circulavam no Rio de Janeiro. Formou-se professora e exerceu a profissão até se diplomar pela Faculdade de Medicina de Minas Gerais, em 1913. Foi a primeira mulher a votar no Brasil e a primeira mineira que se formou em medicina. Nascida em uma geração anterior a de Sylvia, no período da criação do Escritório já tinha uma longa atuação como médica, escritora e militante feminista, participando da Federação Brasileira pelo Progresso Feminino e posteriormente da Aliança Nacional de Mulheres e escrevendo assiduamente artigos sobre saúde,

\footnotetext{
${ }^{35}$ O Fluminense, 3/07/1932:capa.

${ }^{36}$ Idem.
} 
política, feminismo e educação em jornais de Minas Gerais, Rio de Janeiro e São Paulo. Nesta época também atendia numa clínica para senhoras e crianças em Niterói.

Ermelinda atuava como médica desde 1888 - foi a primeira mulher a se formar em medicina no Rio de Janeiro e a segunda do Brasil. Estas primeiras médicas brasileiras sofreram toda sorte de pressão social e com Ermelinda não foi diferente. Sua diplomação provocou a crônica A Machona do historiador Silvio Romero, que terminava com a afirmação: "Fique certo a doutora, que seus pés de machona não pisarão jamais o meu lar" (SILVA, Alberto, 1954 apud RAGO, 2000: 217), o que representa os arraigados preconceitos ainda existentes contra a participação da mulher no espaço público. Em 1931 morava em Niterói, onde estabeleceu uma clínica para senhoras e crianças após um período de estudos de obstetrícia e ginecologia na Europa (VOSNE, 2004).

Maria Jacintha tinha 26 anos e há uma década vivia em Niterói, onde cursou a Escola Normal e lecionava Português e Francês. Paralelamente, havia há cerca de dois anos começado a colaborar com textos críticos sobre literatura e teatro em periódicos do Rio de Janeiro, São Paulo e Santos. Iniciava seus passos na dramaturgia, campo onde se destacou a partir do final da década (RODRIGUES, 2007).

No ano de sua criação, o Escritório fundou uma Escola Trabalhista ${ }^{37}$ gratuita, noturna e direcionada a mulheres, que tinha por objetivo atingir as trabalhadoras, provenientes do operariado. Funcionou ao menos durante um ano, sendo que em 1933 tinha vinte e cinco alunas matriculadas. Além da Escola Trabalhista, a entidade promovia cursos, reuniões e palestras e mantinha uma biblioteca.

A participação tanto de jovens quanto de artistas prestigiados pelo público carioca e pelas instituições acadêmicas nos eventos do Athénée e sua inserção no movimento feminista marcou o início das relações de Sylvia com artistas e intelectuais do Rio de Janeiro e lhe proporcionou o primeiro convite para trabalhar como jornalista.

\footnotetext{
${ }^{37}$ O programa de ensino da Escola Trabalhista foi organizado por Guaraciaba Timóteo (professora de pedagogia do Lyceu Nilo Peçanha) e aprovado pelo Diretor de Instrução Pública do Estado. As primeiras professoras foram Sylvia (Matemática), Maria Jacintha (Francês), Manoelita Paraná (Português), Guaraciaba Timóteo (Instrução Moral e Cívica), Hilda Neumann (Educação Física) e Alzira Reis Vieira Ferreira (Higiene).
} 


\section{3 - Revista Brasil Feminino}

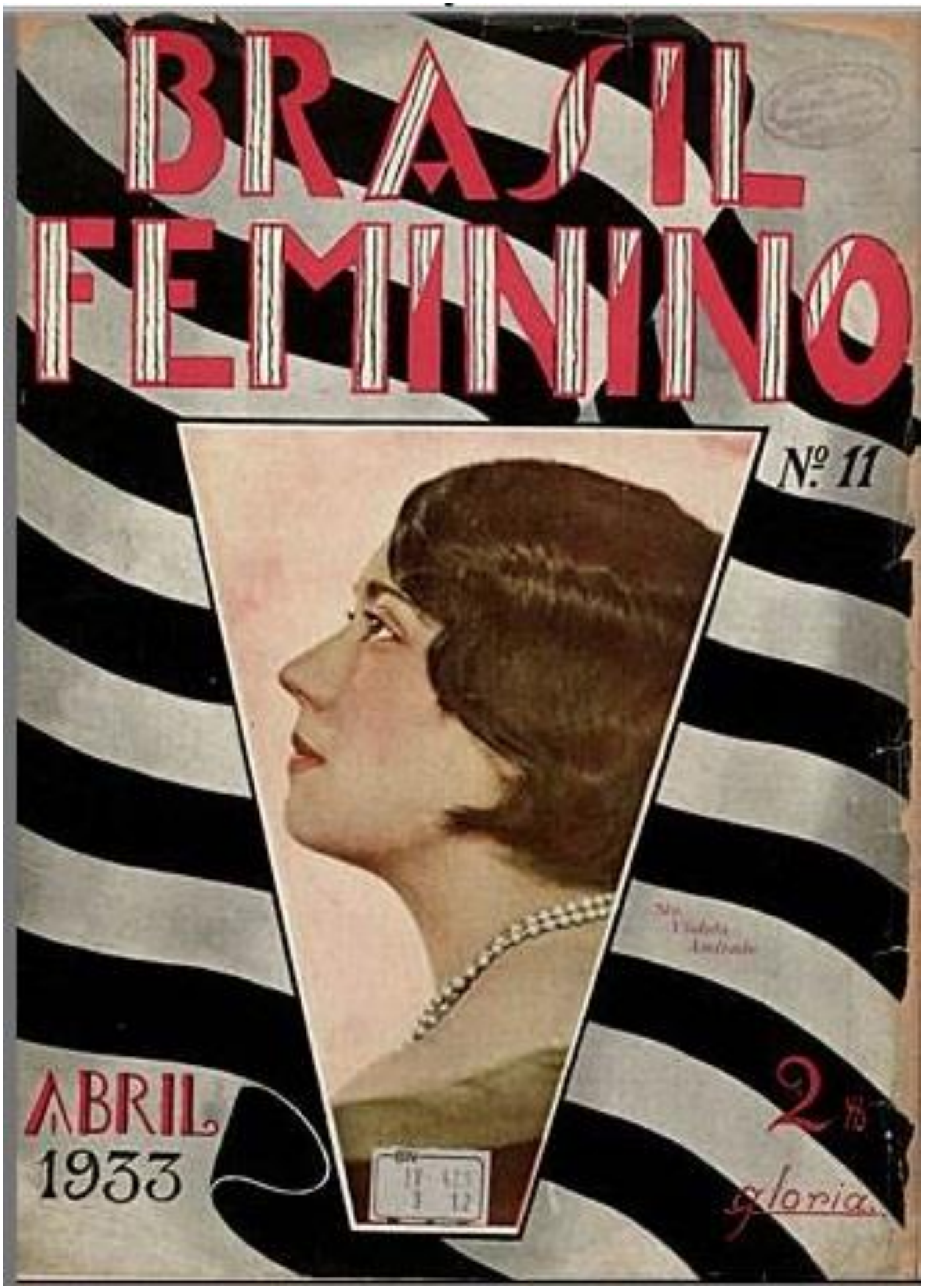

Figura 23 - Reprodução digital da capa da Revista Brasil Feminino, abril/1933. Fonte: Hemeroteca Digital Brasileira 
Em 1932, como registrado em uma carta conservada no arquivo, a diretora da revista Brasil Feminino, Iveta Ribeiro, convidou Sylvia para participar da publicação, "visto ter seguras informações do seu prestígio e talento".

Foi no ano anterior, em uma viagem que fez a Portugal que Iveta que conheceu a revista Portugal Feminino e se inspirou a iniciar um projeto similar no Brasil, a Brasil Feminino. A publicação circulou em todo o território nacional de 1932 a 1937 tendo nos primeiros anos como objetivo principal a divulgação da literatura brasileira e o intercâmbio com escritoras e outros periódicos femininos estrangeiros. Posteriormente foi veículo das ideias da Ação Integralista Brasileira. Propunha o feminismo em voga no período, que não questionava a sociedade patriarcal, advogando que as mulheres deveriam entrar em acordo com ela. Se fundamentava, como as feministas do Athenée e do ELFGCS, no ideário positivista, "que elege a maternidade e a educação das crianças como a função natural da mulher, seu maior objetivo de vida e sua maneira de cooperar para o progresso da humanidade” (ALMEIDA, 1998 apud RAMOS, 2016:4). Na Brasil Feminino escreveram figuras expressivas desta fase do movimento feminista, como Adalzira Bittencourt, Henriqueta Lisboa, Bertha Luz e Rachel Prado ${ }^{38}$.

Iveta era uma escritora, poetisa e declamadora conhecida no meio literário e na colônia portuguesa do Rio de Janeiro, principalmente por sua participação em eventos literários e musicais em companhia, entre outros, de artistas próximos do Athénée, como Eugênia e Álvaro Moreyra, Ana Amélia Carneiro de Mendonça, Antonietta de Souza e Catulo da Paixão Cearense. Vinha de uma família de posses e poder político e era casada e trabalhava com o teatrólogo português José Ribeiro dos Santos, escrevendo e atuando em suas peças desde meados da década de 1920 (RAMOS, 2016). Em 1930, no evento presidido por Bertha Lutz, com a presença do Presidente da República Washington Luís e outras autoridades, por ocasião do ingresso de novos membros na Federação Brasileira para o Progresso Feminino, proferiu o discurso em nome das ingressantes, onde sublinhou que, diferente das críticas injustamente recebidas, as feministas não defendiam "a liberdade absoluta da mulher masculinizada" "39, uma fala que impunha limites, reforçava preconceitos e aceitava os papéis sociais da família patriarcal, definidos como naturais para ambos os sexos. Esta naturalização, no entanto, não se referia como no passado à inferioridade intelectual da mulher, mas a sua função biológica relacionada à reprodução, que justificava a responsabilidade do sexo feminino pela criação e educação das crianças e pelas atividades domésticas.

\footnotetext{
${ }^{38}$ Diário de Notícias, Rio de Janeiro, edição 00738, 29/06/1932.

${ }^{39}$ ABC Política, Atualidades, Questões Sociais, Letras e Artes, edição 00794, 1930:4.
} 
Em fevereiro de 1933, no número dez da Brasil Feminino, o nome de Sylvia consta no expediente como correspondente especial em Niterói e redatora efetiva sobre assuntos proletários. A utilização em sua coluna do termo utilizado por Karl Marx para conceituar a classe social motriz da revolução comunista, indica que neste período já estava possivelmente em contato com o comunismo. A Coluna Proletária inaugurada neste mesmo número propunha o

(...) desenvolvimento da mulher trabalhista, despertando interesse pela exteriorização do pensamento e pela formação de consciências esclarecidas geradoras de uma era melhor. Dedicando-se as emancipadas pelo trabalho, "Brasil Feminino" vai auscultar a mulher proletária e suas aspirações, que transformadas em realidades servirão para elevar o Brasil no conceito universal. ${ }^{40}$

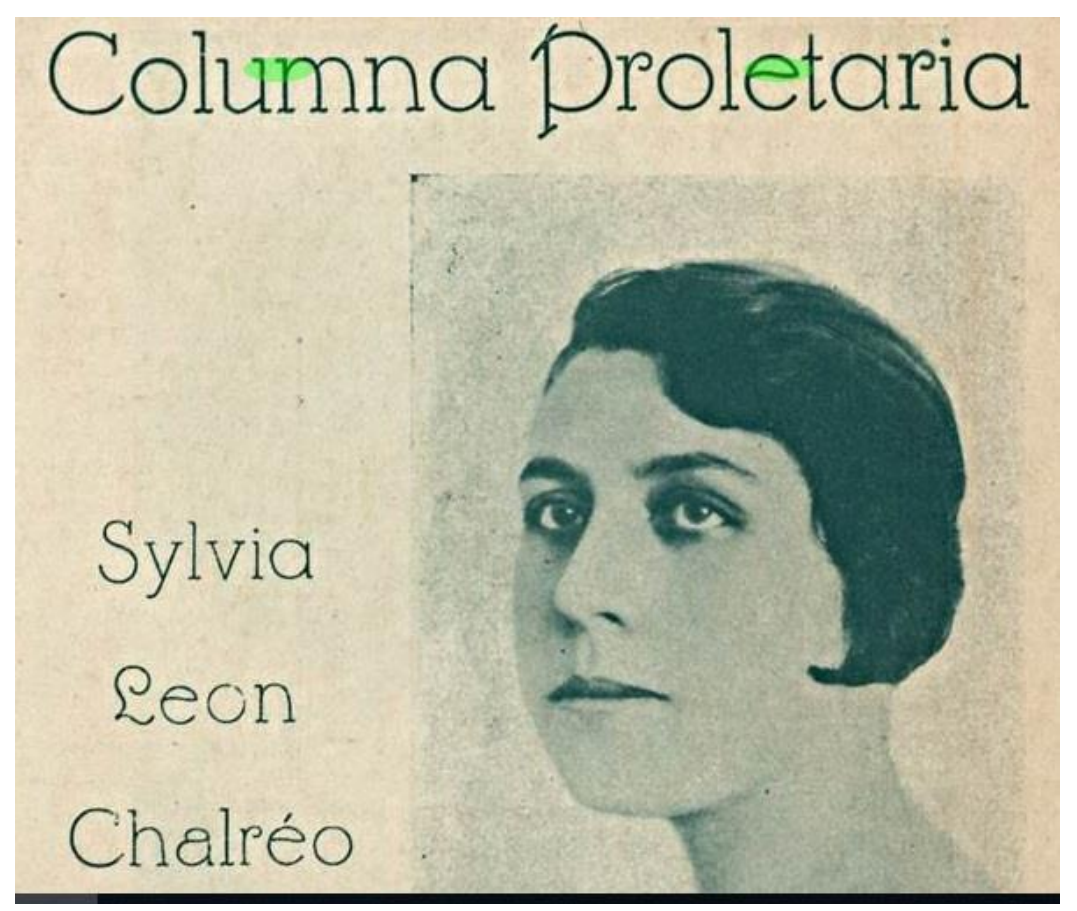

Figura 24 - Reprodução da Coluna Proletária da Revista Brasil Feminino. Fonte: Revista Brasil feminino, fev./mar, 1933. Hemeroteca Digital Brasileira

Na matéria de inauguração, com uma fotografia similar à enviada para divulgação do Athenée estampada em um quarto de página, a coluna anuncia a criação da escola. No número seguinte, o texto de Sylvia exalta a mulher enquanto mãe e "formadora e orientadora da mentalidade do homem", advogando que "a natureza nos ensina ser da mulher a grande responsabilidade biológico

${ }^{40}$ Brasil Feminino, fev./mar, 1933. 
educacional, nas suas fases da formação do cidadão - gestação e crescimento" e as chamando para a responsabilidade de seu voto para o "engrandecimento da nação".

A Coluna Proletária buscava atingir o público de mulheres trabalhadoras, dando conselhos sobre maternidade e cuidados com o lar e divulgando escritoras, poetas e artistas, além de promover concursos literários e apoiar ações de entidades feministas. Estava no entanto, como outras associações feministas criadas pela elite, distante dos reais problemas enfrentados pelas mulheres pobres, trabalhadoras das fábricas, domésticas e em sub empregos. Entre as ações da Brasil Feminino, foi destacada pelos jornais a homenagem à poetisa Gilka Machado, evento no qual Sylvia participou ativamente.

As revistas femininas representaram um espaço onde o interesse intelectual se misturava ao político e se multiplicaram formando uma rede de informações de norte a sul do Brasil. Em 1933, a Brasil Feminino tinha correspondentes especiais em Petrópolis e Niterói, no estado do Rio de Janeiro; Ribeirão Preto e na capital de São Paulo; em Santos Dummont, Juiz de Fora, Pouso Alegre e Belo Horizonte, em Minas Gerais; Cuiabá, no Mato Grosso; Curitiba e Ponta Grossa, no Paraná; Encruzilhada, Rio Grande e Porto Alegre, no Rio Grande do Sul e nas capitais do Espírito Santo, Santa Catarina, Pernambuco, Amazonas, Sergipe, Rio Grande do Norte, Bahia e Pará.

Dois anos depois de seu ingresso na Brasil Feminino, em janeiro de 1934, Sylvia passou a integrar a Associação Brasileira de Imprensa ${ }^{41}$. Foi provavelmente através desta inserção em um universo que ultrapassava as fronteiras do Rio e Niterói onde circulava até então, e das relações que estabeleceu com artistas, em especial do meio teatral, jornalistas e intelectuais feministas, que intensificou seus contatos com o PCB, partido no qual militou durante toda a idade adulta.

Nunca escondeu dos familiares e amigos sua militância, mas silenciou sobre ela em seu arquivo.

${ }^{41}$ O Jornal, Ed 04364, 10/01/1934:2. 
3 - ESFERA, REVISTA DE LETRAS, ARTES E CIÊNCIAS

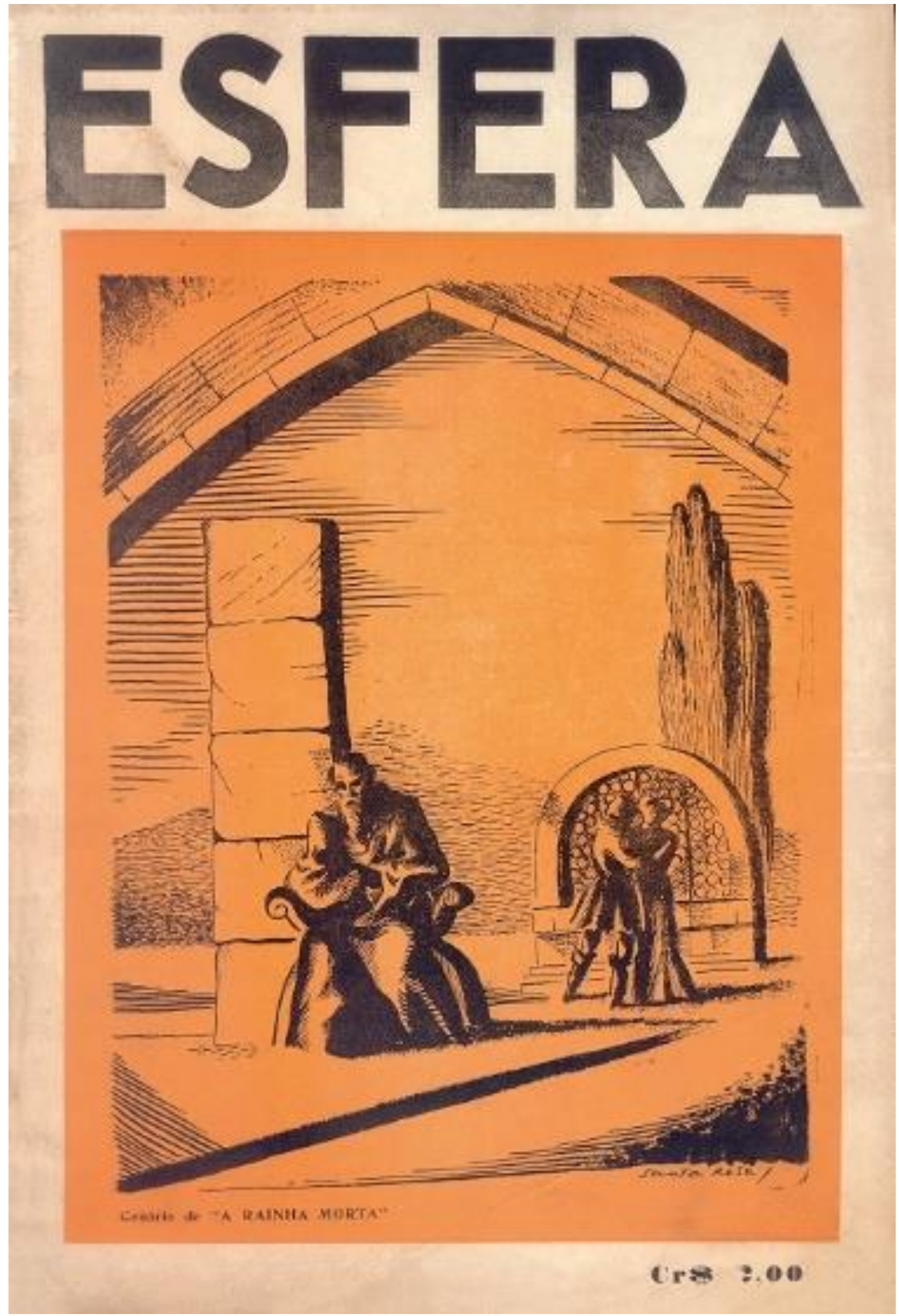

Figura 25-Reprodução da capa da Revista Esfera n 16, 1946. Ilustração de Tomás Santa Rosa. Fonte: Arquivo Silvia 
O PCB, criado em 1922, em Niterói, desde o início dos anos 1930 se organizava e agia na clandestinidade sob a influência da Internacional Comunista, que propagava o ideário marxista pelo mundo. Em 1935, com o objetivo de instaurar no País um governo popular, nacional e revolucionário, promoveu a revolta conhecida como intentona comunista que, totalmente sufocada pelo governo federal, foi motivo para inúmeras prisões e acirramento da perseguição aos membros do Partido. Mas mesmo na clandestinidade, o Partido liderava a Aliança Nacional Libertadora, associação que aglutinava comunistas, socialistas, democratas e antigos tenentes insatisfeitos com o Governo Vargas:

\begin{abstract}
No Brasil já existe uma ampla e organizada associação, denominada Aliança Nacional Libertadora, e da qual já participam um grande número de oficiais e soldados do Exército e Marinha Brasileira. Esta "Aliança” foi criada sob a orientação secreta, mas direta do Partido Comunista Brasileiro, segundo as instruções confidenciais recebidas da Legação Soviética de Montevideo. ${ }^{42}$
\end{abstract}

A ANL se constituiu como uma força democrática, organizando a população em diversas localidades do País, com manifestações públicas, atos, passeatas e comícios, que demonstravam sua popularidade. Neste período, decorrente da associação ser composta por diferentes tendências políticas democráticas, os comunistas tiveram espaço para divulgar suas ideias em "publicações para militares, inúmeros jornais e boletins sindicais e estudantis, além de ter participação em várias revistas culturais e manter três jornais diários (A Manhã, no Rio; A Plateia, em São Paulo e Folha do Povo, em Recife)", criando desta maneira um forte aparato político cultural, que "estendia sua influência a parcelas significativas das camadas médias, como estudantes, militares e intelectuais". Modernistas, como Oswald de Andrade e Patrícia Galvão entraram para o Partido e novas publicações, que se destinavam à divulgação e discussão do socialismo soviético, contavam com a colaboração de autores e artistas militantes ou simpatizantes do PCB (COSTA, 2016).

Em 1936, Sylvia foi detida pelo Polícia Federal, acusada de distribuir panfletos comunistas na prefeitura o que, mesmo tendo sido libertada imediatamente, deu margem a abertura em seu nome de um prontuário no órgão de repressão política do governo federal, a Delegacia Especial de Segurança Política e Social.

\footnotetext{
${ }^{42}$ Trecho do discurso do delegado holandês Van Mine, membro do conselho Executivo do Komintern e relator de assuntos referentes à América do Sul no VII Congresso Mundial da Internacional Comunista, 1935. In: Arquivo Getúlio Vargas, CPDOC-FGV. Disponível em <http://docvirt.com/docreader.net/docreader.aspx?bib=GV_Confid\&pasta=GV\%20confid\%201935.07.25>. Acesso em $4 / 02 / 2018$.
} 
Pouco se sabe sobre as mulheres que participaram da primeira fase do Partido Comunista. Poucas ficaram na história, como Olga Benário Prestes, Patrícia Galvão e Maria Prestes, mas a maioria foi calada, ou como Silvia em seu arquivo, se calou, devido ao medo da repressão promovida pela ditadura militar (1964 - 1985).

Nesta história de Silvia, algumas delas, ligadas principalmente ao mundo das artes, estão representadas. Além dela, são conhecidos os vínculos com o PCB de Eugênia Moreyra e Eneida, que foram presas em 1937 acusadas de participação na intentona comunista, de Maria Jacintha Trovão, que tem um prontuário no DESPS, da jornalista catarinense Maura de Senna Pereira e da paraense Nair Batista.

Cada uma, e provavelmente muitas outras hoje desconhecidas, colaborou de diferentes maneiras com a difusão das ideias comunistas. Em 1937 o Tribunal de Segurança Nacional denunciou como corrés da intentona comunista de 1935, Valentina Leite Barbosa Bastos, Eneida de Moraes, Armanda Álvaro Alberto e Maria Moraes Werneck de Castro $^{43}$ e $O$ Imparcial noticiou as presas políticas em 1937: Emília Moraes, Yole Freitas, Rosa Meirelles e Maria Bornezery ${ }^{44}$

Sylvia e Maria Jacintha, com o apoio do PCB, criaram a revista Esfera, documento que representa e traz representações destas e outras histórias esquecidas. Eneida, Nair e Maura, colaboraram com a revista.

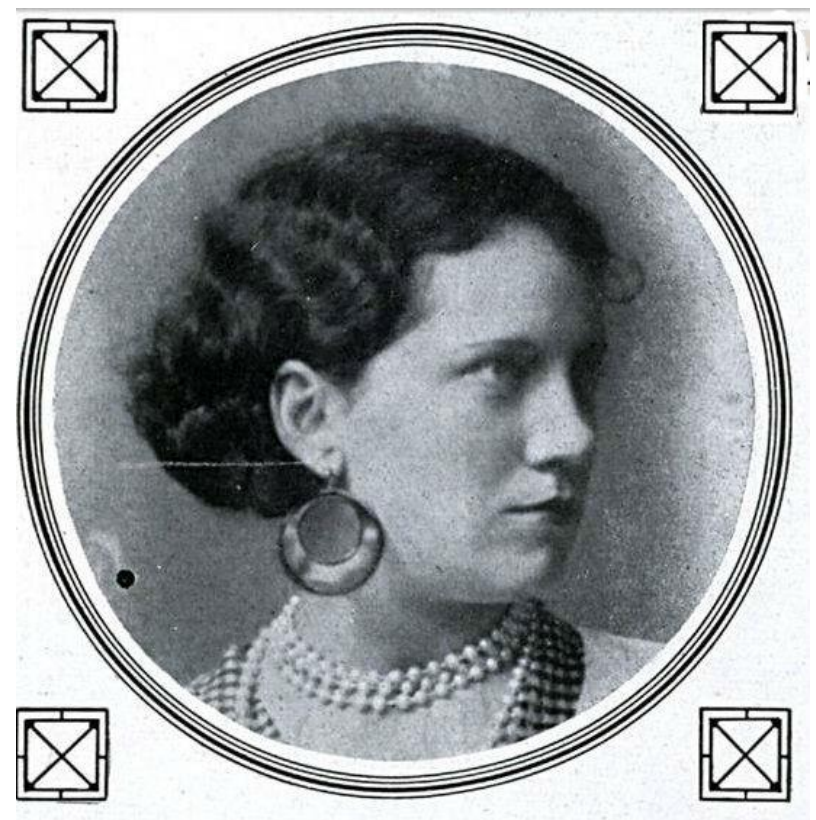

Figura 27 - Eneida de Moraes, c. 1929. Fotografia. Fonte: Fon Fon, 30/11/1929, 23. Hemeroteca Digital Brasileira

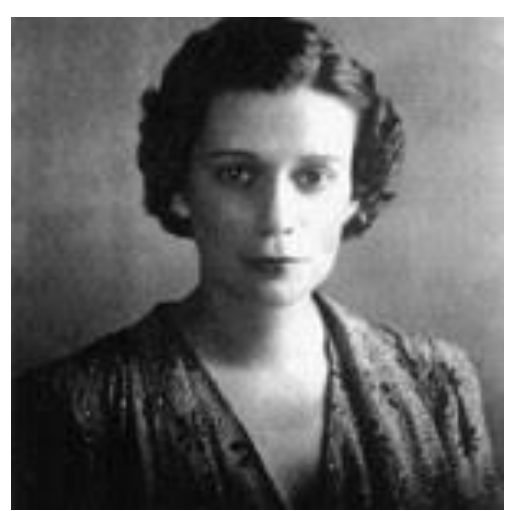

Figura 26 - Maria Jacintha Trovão Campos. Fonte: Focus Portal Cultural

\footnotetext{
${ }^{43}$. Coautoras da rebelião extremista: as mulheres denunciadas no Tribunal de Segurança, A Noite, 20/01/1937:capa. ${ }^{44}$ Os presos políticos, O Imparcial, 11/06/1937:3.
} 


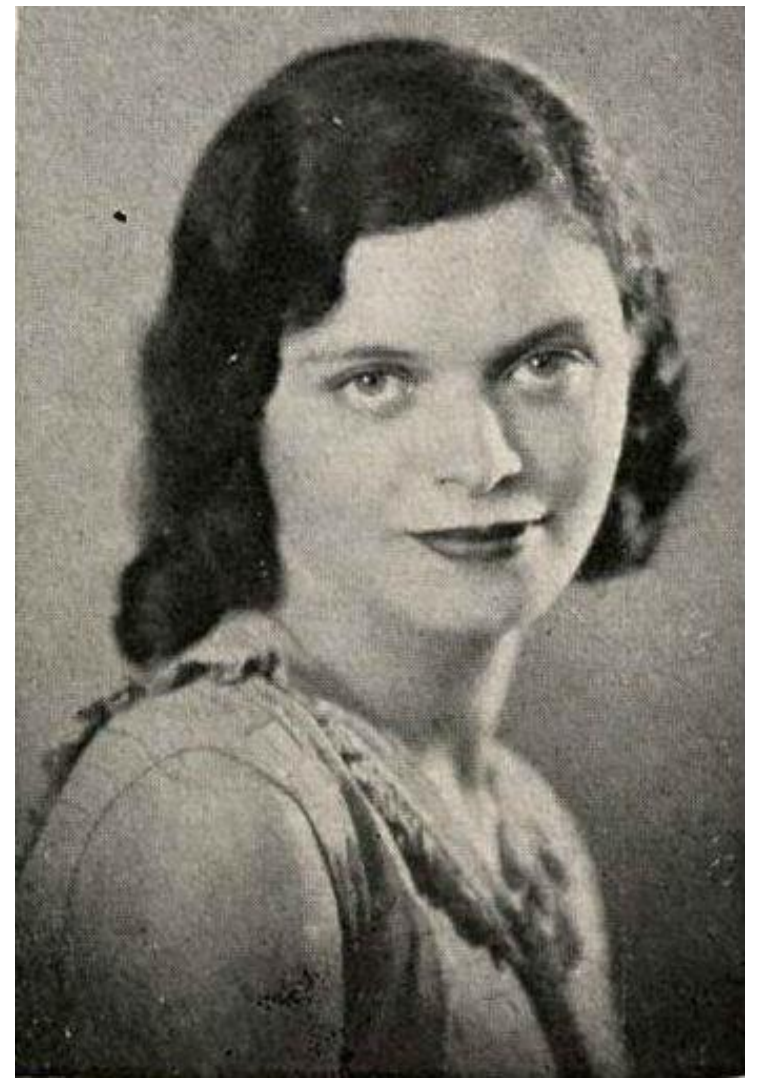

Figura 28 - Nair Baptista, c. 1931. Fotografia. Fonte:

Fon Fon, 28/11/1931, 25. Hemeroteca Digital Brasileira

Figura 29 - Maura de Senna Pereira, c. 1931.

Fotografia. Fonte: Fon Fon, 28/11/1931. Hemeroteca Digital Brasileira

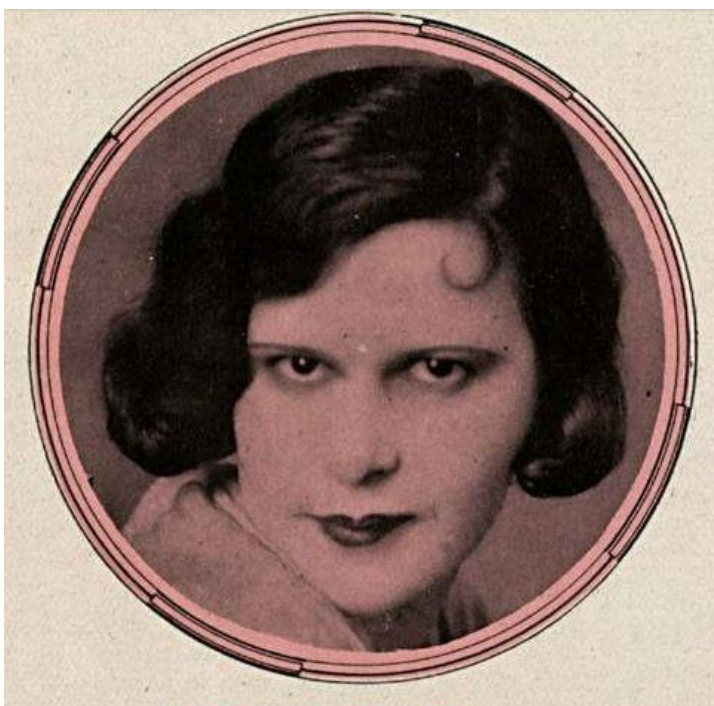

A senhorita Maura de Senna Pereira, Joven e brilhante escriptora de Santa Catharina, nossa apreciada collaboradora e figura de destaque na sociedade de Floriano. polis, ficou noiva do sr. Dorval Lamotte, e mandou, gen. tilmente,, a FON - FON, a participação desse contracto
de casamento, que é uma nota interessante para a vida 
Um dos instrumentos da disseminação do ideário marxista na década de 1930 foi a criação e distribuição pelo PCB de periódicos voltados à política, artes e literatura ${ }^{45}$, destinados à divulgação e discussão de livros, autores e obras de arte, debates sobre o socialismo soviético, literatura proletária e arte social, o que possibilitou a circulação na sociedade do pensamento marxista e das opiniões dos comunistas acerca da conjuntura nacional e internacional (COSTA, 2016).

Subordinada à orientação do PCB, a revista Esfera, de Letras, Artes e Ciências foi criada um ano após a instalação da ditadura do Estado Novo no Brasil e da criação do DIP (Departamento de Imprensa e Propaganda), órgão responsável pela repressão às produções culturais contrárias a ideologia do governo. Nestas condições políticas, não se assumia como uma publicação de orientação marxista, mas como um espaço para representações culturais de posição antifascista.

Quatro anos antes de sua criação, em 1934, no $1^{\circ}$ Congresso de Escritores Soviéticos, o realismo socialista se converteu em arte oficial na URSS e se tornou a mais importante bandeira cultural do Partido Comunista, se propagando pelo mundo através das ações lideradas pela Internacional Comunista (Idem, 2016). O estilo, segundo Aleksandr Gerasimov, é "realista na forma" e "socialista no conteúdo", ou seja, a obra de arte deveria ser figurativa e descritiva, para que fosse compreendida por toda a população, e seu conteúdo um instrumento de propaganda do regime socialista $^{46}$.

Havia se passado mais de um século desde a primeira publicação voltada à cultura no Brasil, a Niterói, Revista Brasiliense de Ciências, Letras e Artes, lançada em 1836. Considerado o segundo periódico brasileiro, Niterói foi produzida em Paris e por lá circulou a maior parte da tiragem dos dois números publicados. Mas a partir da década de 1920, revistas e jornais de artes e literatura haviam se proliferado pelo País e se tornado o espaço ideal e mais utilizado para a realização do debate cultural e divulgação de obras de autores brasileiros. Era através deles que a comunidade intelectual dialogava entre si e com o público e que as diversas tendências políticas e culturais lutavam pela conquista da hegemonia em seus campos de atuação (MARTINS, 2008).

\footnotetext{
${ }^{45}$ Entre elas, Boletim de Ariel, Espírito Novo, Revista Proletária (Rio de Janeiro), Esfera (Rio de Janeiro), Problemas (São Paulo), Revista Seiva (Salvador), Continental (Rio de Janeiro), Leitura (Rio de Janeiro), Tribuna Popular (Rio de Janeiro), Voz Operária, Literatura (Rio de Janeiro), Problemas (Rio de Janeiro), O Popular (Recife), Fundamentos (São Paulo), Para Todos (Rio de Janeiro), Orientação (Recife), A Classe Operária (Rio de Janeiro), Horizonte (Porto Alegre), Horizonte (Belo Horizonte), Imprensa Popular (Rio de Janeiro), Horizontes do Mundo (São Paulo) e a Revista Brasiliense de São Paulo (PAIVA, 2013).

${ }^{46}$ REALISMO Socialista. In: ENCICLOPÉDIA Itaú Cultural de Arte e Cultura Brasileiras. São Paulo: Itaú Cultural, 2019. Disponível em: <http://enciclopedia.itaucultural.org.br/termo403/realismo-socialista〉. Acesso em: $01 \mathrm{de}$ Mar. 2019. Verbete da Enciclopédia. ISBN: 978-85-7979-060-7.
} 
Como observa o sociólogo Sergio Miceli, nesse período "em termos concretos, toda a vida intelectual era dominada pela grande imprensa, que constituía a principal instância de produção cultural da época e que fornecia a maioria das gratificações e posições intelectuais" (MICELI, [2001] 2005, p. 17). Os jornais e revistas ilustrados constituíam o lócus em que tais intelectuais se encontravam, expunham seus trabalhos e propagavam seus ideais. (SIMIONI, 2014:3)

Em 1938, ano da criação da Esfera, já estavam completamente disseminados no Brasil e ainda eram os mais importantes meios de comunicação no Brasil.

\section{1 - Trajetória da revista}

Em 18 de abril de1938 o Jornal do Comércio do Rio de Janeiro tornou público o contrato da Empresa de Leitura e Publicidade Ltda., "firma composta dos sócios cotistas Áureo Ottoni de Mendonça Junior, Maria Jacintha Trovão da Costa Campos e Sylvia de Leon Chalreo para o comércio de publicações”, à Rua Uruguaiana n. 86, $8^{\circ}$. Andar, sala 805, com o capital de 12:000\$000 réis. Um mês depois a ELP editou o primeiro número da revista Esfera.

A Esfera começou suas atividades com força total, editando um exemplar por mês, num trabalho árduo que exigiu de Sylvia dedicação quase exclusiva, como relata a sindicância realizada em 1939 e incorporada ao seu prontuário do DESPS:

É diretora da revista Esfera, cercando-se de vários elementos também com antecedentes na DESPS, dos quais destacam-se Maria Jacinta, Antônio Moreira Franco, Araújo Jorge e Medeiros Lima. A sindicada, que já foi Chefe da Seção da Diretoria de Engenharia e trabalhou na Diretoria de Estatística está no momento à disposição do Gabinete do Prefeito. Sylvia raramente vai a repartição, pois passa os dias na redação da citada revista Esfera, sediada no Edifício do Liceu Literário Português, $7^{\circ}$ andar, sala 708, onde também reside.

Ela e seus sócios se empolgavam e faziam planos imensos para a revista. Pretendiam, seguindo a orientação do PCB, que fosse um periódico que contribuísse para fomentar o intercâmbio político e cultural entre o Brasil e países da América e Europa.

Foram editados 26 números em duas fases: oito entre 1938 e 1939 e 18 após 1944, sendo que o último saiu em 1950. No início Sylvia assinava como redator chefe e a companheira das lutas feministas em Niterói, Maria Jacintha, como diretor. Ambos os cargos eram grafados no expediente da revista no masculino. Na segunda fase, sem a parceria de Maria Jacintha, a jornalista feminista Maura de Senna Pereira faz parte do expediente, exercendo o cargo de secretário. 
A Esfera reuniu intelectuais, escritores e artistas que se uniam aos protestos contra a ditadura do Estado Novo, a censura e a perseguição aos comunistas e foi veículo das ideias da Aliança Nacional Libertadora durante a Segunda Grande Guerra. Entre 1938 e 1950, foram publicados 24 números, com lacunas de tempo entre as edições. Os seis primeiros mensalmente, de maio a setembro de 1938 e o sétimo teve um atraso de um mês, saiu só em dezembro. Durante este período funcionou no endereço registrado no contrato social, no centro do Rio de Janeiro e além de Sylvia e Maria Jacintha, sua equipe era composta por Áureo Ottoni, gerente, e Frederico Reys Coutinho, secretário.

As duas sócias já se relacionavam desde o início da década em Niterói, participando da vida cultural da cidade, do mundo do teatro, de ações pela emancipação feminina e na militância no Partido Comunista do Brasil. Há poucas informações biográficas sobre Áureo Ottoni, mas a sua autoria de dois volumes do livro Bibliografia Brasileira de Teatro (OTTONI, 1949 e 1952) o situa próximo da dramaturga Maria Jacintha. Foi funcionário público, tendo se aposentado como chefe da seção de diretoria e estatística da Procuradoria da Fazenda Municipal do Distrito Federal. Frederico Reys Coutinho, foi organizador de três antologias de poemas editadas pela Editora Vecchi, As mais belas poesias de amor (1946), As mais belas poesias patrióticas e de exaltação ao Brasil (1946) e Os mais belos contos brasileiros de amor (6 $6^{\text {a }}$ edição de 1966), e tradutor nas décadas seguintes, de $O$ Comunismo e os Cristãos $^{47}$, uma série de ensaios de autoria de intelectuais católicos franceses publicados também pela Editora Vecchi em 1939, e Os colossos do conto da velha e da nova Rússia (1944), da editora Mundo Latino.

O nono número da Esfera foi publicado um ano depois, em novembro de 1939, com alterações na equipe administrativa e sede. A nova sede era a sala 708 do Liceu Literário Português, na Rua Senador Dantas, 118, também na região central, cerca de mil metros da antiga instalação. Neste ano a revista passou a ter o português Afonso de Castro Senda como representante em Portugal, o que explica o uso da instituição portuguesa como sede. Um carimbo com o endereço Rua 13 de maio, 38, salas 86 e 87 sobre o nome do Liceu impresso nesta publicação, no entanto, denota seu caráter temporário: a Esfera mudou de sede mais três vezes, todas localizadas no Centro do Rio de Janeiro ${ }^{48}$. Neste número o expediente também estava mudado e da equipe anterior só restava Sylvia, que assumiu o cargo que pertencera à Maria Jacintha, a diretoria. Oswaldo Dias da Costa a substituiu no

\footnotetext{
${ }^{47}$ MAURIAC, François et al. O Communismo e os christãos. Coleção Documentário, Editora Vecchi, Rio de Janeiro, 1939. Esta obra é mencionada em: Jornal do Commercio, Rio de Janeiro, 02/04/1939, Bibliografias:9.

${ }^{48}$ De 1944 a fevereiro de 1946 funcionou na Rua do Lavradio, 55, (números 9 a 12); de março de 1946 a 1947 (números 13 a 16), na Rua do Rosário, 139 e a partir de agosto de 1948 (números 17 a 24), na Avenida Graça Aranha, 19.
} 
cargo de redator; a secretaria ficou sob a responsabilidade de Rui de Carvalho e Maria Torres encarregou-se da gerência.

O baiano Oswaldo Dias da Costa já a partir do segundo número da Esfera participava das edições, como responsável pela seção Comentando Livros, onde publicava críticas literárias. Maria Torres e Rui de Carvalho trabalharam apenas nesta edição, onde ele também comentou o livro Tierra Amarga, do poeta uruguaio Serafim Garcia.

No número seguinte, publicado em 1944, Áureo Ottoni retoma o cargo de gerente e Maura de Senna Pereira assina como secretária. Desde a década de 1920, Maura se engajara na campanha pela emancipação e direito ao voto feminino e na época era conhecida no Rio de Janeiro e nos círculos feministas por suas publicações em jornais e revistas que circulavam em grandes cidades dos Estados do Rio de Janeiro e São Paulo, como Vida Doméstica e Fon Fon. Havia se mudado aquele ano para o Rio de Janeiro, onde intensificou sua colaboração na imprensa e secretariou a publicação da Esfera de 1944 até o último número da revista. Sua trajetória de vida e atuação no espaço público foi estudada por Rosa Maria Steiner Schroeder na dissertação Uma mulher além de seu tempo: Maura de Senna Pereira (SCHROEDER, 1997).

A partir de então, a equipe administrativa permaneceu a mesma, com exceção do cargo de gerente que foi ocupado pelo artista plástico Durval Alvarez Serra nos números dez a dezesseis e retomado por Áureo Ottoni da décima sétima até a vigésima quarta e última Esfera.

O nono número apareceu só depois de cinco anos, em março de 1944, com foco na propaganda política contra o fascismo. Na página de abertura, uma foto de Getúlio Vargas acima do título da primeira matéria, Unidade para a Vitória, representa a união dos comunistas em torno de Vargas aprovada na II Conferência Nacional do PCB realizada no ano anterior, após a entrada do Brasil na Segunda Guerra Mundial ao lado dos Aliados.

Nesta conferência, que reuniu em Engenheiro Passos, RJ, representantes do Distrito Federal, São Paulo, Rio de Janeiro, Minas Gerais, Paraná, Rio Grande do Sul, Bahia, Sergipe e Paraíba, foi decidido que o Partido iria se empenhar para o Brasil entrar na guerra contra o nazismo; Prestes, mesmo encontrando-se preso, foi eleito para o Comitê Central no cargo de Secretário Geral; Foi aprovado uma linha política inspirada nos modelos da união nacional em torno do governo, com o apoio incondicional a Vargas e o fortalecimento ideológico do partido contra as tendências de liquidação do PCB. As resoluções aprovadas serviriam de linha condutora das posições do PCB no período de 1945 a $1947 .{ }^{49}$

${ }^{49}$ MARXISTS Internet Archive - Dicionário Político. Conferência da Mantiqueira. In: 
As críticas, poemas e obras literárias ali publicadas são em sua maioria relacionadas à divulgação das ideias do Partido Comunista, da Aliança Nacional Libertadora, da Liga de Defesa Nacional e de outras associações e organizações antifascistas.

Pouco mais de um ano, já no final da guerra e após a rendição da Alemanha, foi editado o número seguinte. A capa é um retrato de Luís Carlos Prestes feito a bico de pena por Quirino Campofiorito, com a inscrição O Grande Líder Nacional. Este exemplar, com o subtítulo Discurso de Luiz Carlos Prestes impresso acima do desenho, é praticamente todo dedicado ao líder comunista, trazendo na íntegra o discurso que proferiu em comemoração à anistia política no comício de 1945 , realizado no Estádio de São Januário, no Rio de Janeiro.

Seis meses depois saiu o décimo primeiro exemplar com o subtítulo Documentos Históricos - A palavra de Luís Carlos Prestes. Desta vez na primeira matéria, ilustrada com o desenho Comício Popular de Paulo Werneck, a Esfera saudou a democracia:

\begin{abstract}
O povo decidiu o caminho democrático que o Brasil está trilhando. Declarou guerra ao Eixo, realizou a gloriosa Força Expedicionária Brasileira, venceu nos campos de batalha da Europa, conquistou a anistia para os presos políticos, a legalidade do Partido Comunista do Brasil, a liberdade de imprensa, a Constituinte, a dissolução do Tribunal de Segurança Nacional, a derrubada do famoso $177^{50}$, opressor do funcionalismo e elegeu seus candidatos em eleições livres e honestas para a presidência da República e Assembleia Constituinte. Esfera, revista de cultura e profundamente antifascista, se congratula com o proletariado e o povo, organizados em seus partidos e sindicatos, na luta pela democracia no Brasil. ${ }^{51}$
\end{abstract}

De 1946 a 1950 foram publicados mais 12 números. Em 1946, quando o PCB vivia uma fase de legalidade, saíram os números 12 a 16; em agosto, setembro/outubro e dezembro de 1948 os números 17, 18 e 19; em 1949 saíram as edições de janeiro/março, abril/maio e outubro. Por fim em 1950 foram publicados os últimos dois números: janeiro/fevereiro e maio de 1950.

O cancelamento do registro do Partido Comunista em 1947 (depois de mais de três anos de plena atividade política), a cassação dos mandatos parlamentares no ano seguinte e o acirramento da guerra fria contribuíram para uma mudança nos rumos da política cultural do PCB. Assim como vinha acontecendo na União Soviética, passou a adotar uma política que controlava as manifestações artísticas, exigindo que servissem exclusivamente de instrumento político, o que desagradou setores

https://www.marxists.org/portugues/dicionario/verbetes/c/conferencia_mantiqueira.html>. Acesso em: 18 novembro 2018.

${ }^{50}$ Artigo da Constituição de 1937 que dava ao Governo o poder de aposentar o funcionário público sem aviso prévio.

${ }^{51}$ Esfera, Rio de Janeiro, n.11:9. 
da intelectualidade brasileira fazendo com que muitos se afastassem do campo de influência comunista, esvaziando a ala intelectual do Partido.

Tudo isto colaborou para o fim da publicação. Sylvia foi a única integrante da equipe inicial da Esfera que participou de todos os números, mas em 1950 quando o último foi publicado, ela já estava totalmente envolvida com as artes plásticas, para onde direcionava seu entusiasmo.

\section{2 - Rio de Janeiro, Bar Amarelinho e Revista Dom Casmurro}

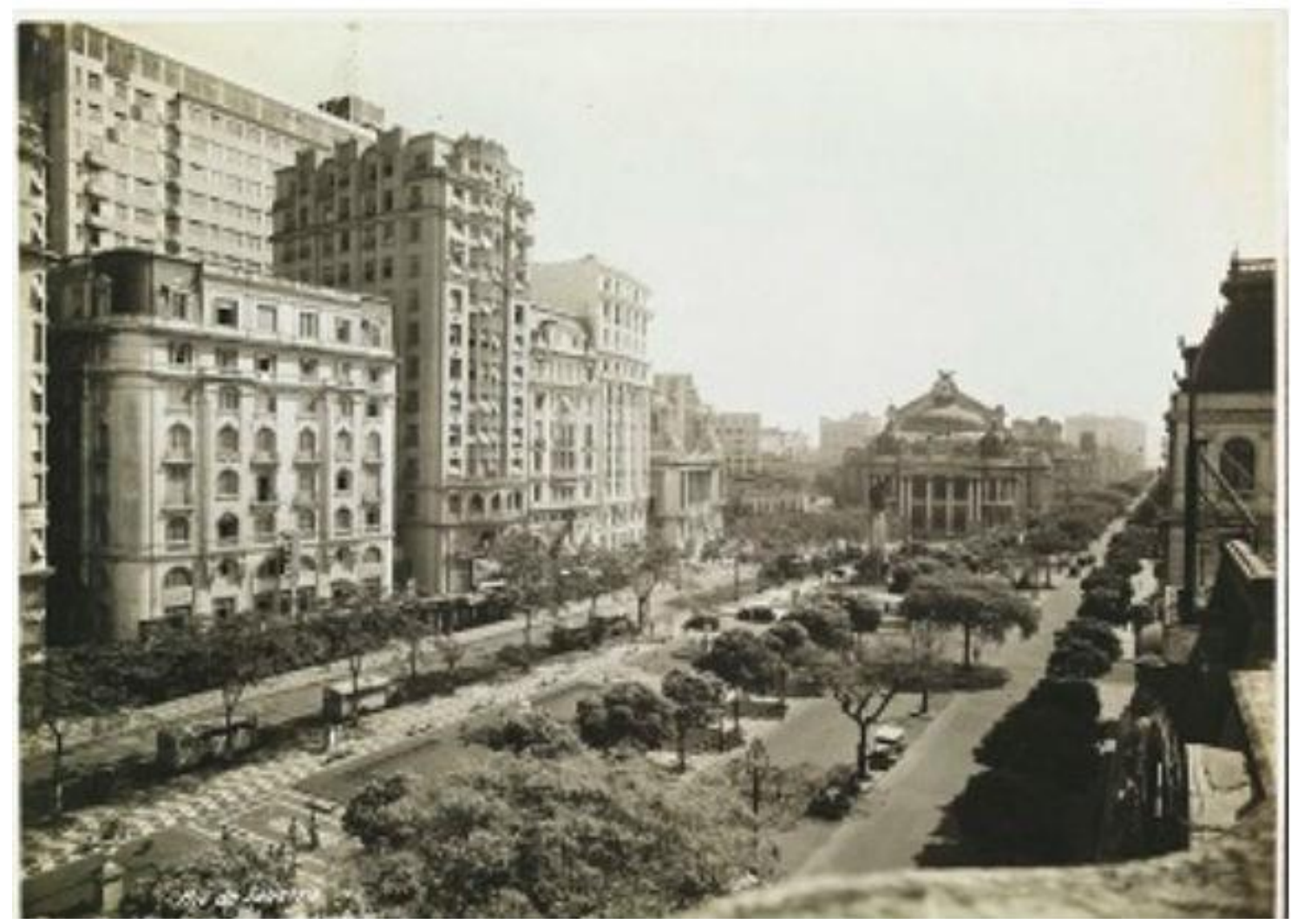

Figura 30 - Autor desconhecido, Cinelândia, Rio de Janeiro, c. 1935. Fonte: Álbum do Rio de Janeiro, BN Digital, domínio público

As páginas da Esfera também representam a agitação política e cultural do Rio de Janeiro no final da década de 1930. A cidade, sede do governo desde meados do século XVIII, era não apenas a capital do Brasil, mas junto com São Paulo, era considerada capital da intelectualidade brasileira.

O Centro já havia assumido sua função comercial e administrativa no zoneamento da cidade e se caracterizava pelo trânsito intenso de automóveis e pessoas, pela presença de prédios cada vez mais altos e de inúmeras propagandas nas paredes e muros das vias públicas. O processo de modernização iniciado nos primeiros anos do século com a reforma urbana do prefeito Pereira Passos e intensificado nas décadas seguintes, havia transformado definitivamente a zona central. Em meados dos anos 1920 prédios altos, como o Glória, Natal, Capitólio e Fontes, haviam sido construídos na 
região e, em 1929, o jornal A Noite, o primeiro arranha céu do Brasil, já se instalava em um edifício de 22 andares e 102 metros de altura na Praça Mauá. Sob calor quase permanente e em meio à multidão que povoava as ruas do centro da cidade ouvia-se milhões de sons: lojas de música deixavam escapar as músicas de suas vitrolas; gritos de vendedores ambulantes cortavam a paisagem; pairavam no ar os murmúrios de conversas, ruídos e buzinas dos automóveis, sirenes e sinos, rádios e pregões ${ }^{52}$. Estes sons eram tão presentes que um artigo publicado no Jornal do Brasil no final da década dava ao Rio de Janeiro o título de "cidade do barulho"

No ano da criação da Esfera, o Palácio Capanema, sede do Ministério da Educação e Saúde e primeiro edifício modernista construído na cidade $(1936)^{54}$, já convivia com o aeroporto Santos Dumont (1936), o Cristo Redentor (1931) e com antigos edifícios de estilo eclético e Art déco que abrigavam empresas, hotéis, teatros, cinemas e bares, representando na arquitetura a modernidade do Rio de Janeiro e do Brasil. O Edifício do Ouvidor, a primeira sede da Esfera, ainda ocupa toda a esquina da Rua do Ouvidor com a Rua Uruguaiana e na época abrigava em suas salas escritórios e oficinas de empresas comerciais, financeiras e industriais, associações políticas e culturais, consultórios médicos e dentários entre outros estabelecimentos, como registrado em anúncios de imóveis nos jornais da época.

A menos de um quilômetro dali, na Cinelândia, centro artístico e cultural da cidade, envolvidos por uma atmosfera europeia criada principalmente pela presença dos imponentes edifícios construídos nas décadas anteriores, sedes do Teatro Municipal, Supremo Tribunal Federal, Biblioteca Nacional, Museu Nacional de Belas Artes e Câmara Municipal, intelectuais, estudantes e artistas se reuniam nas já tradicionais rodas de boemia carioca para se conhecer, divertir, expor seus trabalhos e buscar ou firmar sua inserção no meio intelectual da Capital do País ${ }^{55}$. Os temas mais recorrentes nas conversas giravam em torno de política, cultura popular, lançamentos de discos, filmes, peças de teatro e programas de rádio, da arte moderna e dos romances que vinham sendo editados e publicados

\footnotetext{
${ }^{52}$ COSTA, D. Cinco variações urbanas em uma fuga. A Nação, Rio de Janeiro, 25/061933:6.

${ }^{53}$ A cidade do barulho. Jornal do Brasil, Rio de Janeiro, 25 março 1938:5.

${ }^{54}$ O Palácio Capanema foi projetado e construído por Lúcio Costa e equipe e inaugurado em 1936 para ser sede do Ministério da Educação e Saúde. Segundo Simioni, constitui uma primorosa síntese visual do modernismo brasileiro: por um lado sua arquitetura é associada a um discurso progressista voltado à celebração do futuro e por outro lado reinsere uma suposta "tradição" arquitetônica brasileira. (SIMIONI, 2014).

${ }^{55}$ A região que compreende a Praça Floriano Peixoto e adjacências, no centro do Rio de Janeiro, já era há mais de uma década conhecida como Cinelândia, devido a instalação de três salas de cinema no local, os Cine Capitólio (1925), Cine Teatro Glória e Cinema Império foram os primeiros; depois vieram o Cine Odeon (1926), Pathé Palace (1928), Cine Alhambra (1932), Cine Teatro Rex (1934), Orly (1935), Plaza (1936), Metro Passeio (1936), Vitória (1942) e Cine Mesbla (1959). (GONZAGA, 1996 apud SOUSA, 2014).
} 
em grandes tiragens. Muitas vezes acontecia de alguém recitar um poema ou ler um trecho de um conto ou romance em elaboração.

Entre os pontos de encontro mais procurados estava o Bar Amarelinho, frequentado por Sylvia e por grande parte dos colaboradores da Esfera. Segundo Joel da Silveira, passavam por lá romancistas, poetas, músicos, ensaístas e contistas, consagrados e iniciantes, estudantes, profissionais liberais e funcionários públicos, entre eles muitos moradores da cidade e visitantes de outros estados e países. Era também um ponto de encontro de jornalistas da Dom Casmurro, revista literária semanal que mantinha uma posição antifascista e alinhada ao PCB e cujos principais redatores também colaboravam com a Esfera (SILVEIRA, 1998).

Diferentes sotaques, modos de falar e palavras permeavam estes encontros. Podemos imaginar o vocabulário e sotaques de conversas entre a carioca Sylvia, a cearense Rachel, o paulista Mário, o alagoano Graciliano e o paraibano José Lins. Joel Silveira, jornalista e frequentador assíduo do Amarelinho nesta época, conta que o bar era "ponto de encontro dos literatos e também quartelgeneral dos intelectuais comunas" (SILVEIRA, 1998:75) e "um reduto de Mário de Andrade e sua corte de jovens literatos. Os de passagem eram numerosos, - quem não passava por lá? Romancistas, poetas, ensaístas, contistas, gente já consagrada e iniciantes, dava de tudo" (Idem, 1998:132).

Entre os colaboradores da Dom Casmurro que também atuavam na Esfera estão Álvaro Moreyra, que foi com Brício de Abreu um de seus criadores e redator chefe até 1941, tendo publicado quatro vezes nos oito primeiros números da Esfera; o jornalista Antônio Dias Tavares Bastos, o diplomata cubano Alfonso Hernandez Catá, o folclorista Amadeu Amaral Junior, o secretário de redação da Dom Casmurro e crítico literário conhecido na época, Danilo Bastos, o diplomata Enrique Rodriguez Fabregat, o tradutor Hamilcar de Garcia, João Augusto de Seabra Mello, Joel Silveira, um dos responsáveis pela Dom Casmurro e ativo colaborador da Esfera, com publicações de contos e crônicas em todos os sete primeiros números, além de José Alves Ribeiro, Jorge de Lima, Mário Sette, Marques Rebello, Mello Lima, Murilo Mendes, Nilo da Silveira Werneck, Odilon Negrão, Omer Mont'Alegre, Paulo Cavalcanti, Paulo Werneck, Sérgio Soares, Fábio Leite Lobo e Remy Fonseca.

Esta crônica de Rubem Braga, publicada usando o pseudônimo Chico ${ }^{56}$, em 1938 o ano da inauguração da Esfera, representa com a maestria do escritor, o ambiente onde Silvia circulava, fazia os contatos e buscava as matérias que seriam publicadas.

\footnotetext{
56 "Por muito tempo Rubem Braga manteve uma crônica diária no matutino "O Imparcial", que assinava com o pseudônimo Chico". (Acadêmica, s/p, n. 45, ago, 1939) apud VERGARA, A, Rubem Braga e as crônicas publicadas no Imparcial em 1938, Estação Literária, Londrina, jul. 2013: 86.
} 
Temos agora no Rio um café literário: O Amarelinho, na Cinelândia. Ali toda tarde se juntam jovens poetas, romancistas, pintores, escultores, homens entendidos em cinema, em teatro, ensaístas, críticos, filósofos, gente assim. Ali tomam cafezinho ou bebem Chopp, às vezes média com pão e manteiga. Ali formam rodas de pequeno consumo, mostram seus inéditos, desenrolam seus sonhos, sobre as mesinhas amarelas, falam de poesia olhando as mulheres que passam formam vaquinhas para a despesa e para as obras de arte, contam anedotas, discutem livros, falam mal uns dos outros, elogiam-se, exaltam-se, sorriem melancolicamente, ferem duelos de ironias, passam as tardes. Às vezes há rodas ilustres com romancistas de nome feito, pintores conhecidos, poetas considerados. Às vezes há rodas de infra-literatos, velhos fracassados, mocinhos tímidos e frementes que sempre querem ser apresentados a alguém. O prestígio de o Amarelinho ficou provado quando um bloco dissidente se retirou e estabeleceu seu quartel general no Angrense. Há também os literatos que combatem o Amarelinho, que desprezam os fregueses do Amarelinho, as suas rodinhas, as suas piadas, as suas tardes perdidas. Combatem a "vida de café" que chamam de dispersiva, inútil, cabotina e improdutiva. Pode ser que estes tenham razão. Mas, não se trata de ter razão. O Amarelinho é um fato. Quem quer, vai lá; quem não quer, não vai. O que realmente é dispersivo, não é o amarelinho, é a vida. É a vida que obriga tantos homens a fazer ao mesmo tempo tantas coisas como, trabalhar, amar, ler, comer, brigar, beber, ir aos encontros, ser patriota, respeitar as leis, etc, etc. Está visto que em geral tudo fica mais ou menos confuso. Não é possível. O melhor é dormir durante a noite, descansar na parte da manhã e passar a tarde no Amarelinho. ${ }^{57}$

\section{3 - Linha e organização editorial}

A Esfera publicou críticas literárias e de artes em geral (cinema, música, pintura, teatro e cinema), programação de rádio, cinema e teatro, artigos literários e poéticos, alguns inéditos, ensaios sobre história, folclore, saúde e filosofia, ilustrações e fotografias.

Começou com cinco colunas: Sobre Literatura Hispano-Americana (que a partir do terceiro número passou a se chamar Letras Hispano Americana), escrita por Rodriguez Fabregat, em espanhol; Panorama Cultural Português, de Afonso de Castro Senda, que a partir do segundo número passou a se chamar Documentário Cultural Português (composta por um artigo sobre a vida cultural em Portugal, anúncios comentados de eventos artísticos e publicações de livros e periódicos no país, finalizando com uma síntese destes eventos e um comentário final elaborado por Afonso, o apêndice), Teatro, Rádio e Cinema. A cada novo número a editoria acrescentou novas colunas: no número dois surgiram Comentando Livros, com críticas à literatura brasileira escritas por Dias da Costa, Vida

\footnotetext{
${ }^{57}$ Grypho 7, O Imparcial, Rio de Janeiro, 17/11/1938:5.
} 
Artística, que divulgava eventos em países da Europa, América Latina e Brasil e Livros e Revistas, com resenhas e notas sobre obras recém publicadas no Brasil e no exterior. No terceiro número surgiu O Livro Estrangeiro, crítica literária internacional por Dias da Costa; no quarto foi criada a seção Jornais; no quinto, Paralelos Históricos, onde foi publicado o ensaio Mazdekismo e Osirismo de Abel Salazar, e Momento Internacional, coluna política assinada por Paulo Zingg. No sexto, surgiram Reportagem Fotográfica e Transcrições, por diferentes autores. Nos próximos dois números até a oitava edição não houve alterações. As colunas Vida Artística, Livros; Teatro, Cinema, Revistas e Rádio eram assinadas apenas com as iniciais S (Sylvia?), M. J. (Maria Jacintha?), E. (Eneida?), F (Frederico Reys Coutinho?) e outras.

Mesmo não tendo uma coluna especialmente destinada às artes visuais, este foi um tema bastante explorado pela revista. Silvia, a responsável por esta editoria, esteve em contato com o mundo das artes desde a infância, pois seu pai era secretário da Escola Nacional de Belas Artes, mas não era tão próxima deste circuito no Rio de Janeiro. Sua relação com o PCB foi fundamental para a escolha dos colaboradores, que recaiu em críticas e artigos dos brasileiros Flávio de Carvalho, Geraldo Ferraz, Jorge Amado e R. de C (Rui de Carvalho?). Sylvia foi a maior colaboradora em artes visuais, escrevendo quatro artigos sobre artistas e exposições de artes. A revista também publicou e reproduziu gravuras, ilustrações e pinturas de artistas brasileiros e estrangeiros.

Artigos que não se encaixavam nestas colunas, assim como as obras ficcionais, foram dispostos nas páginas sem uma organização perceptível, dando a crer que houve importante interferência do diagramador nesta tarefa. Mas a opinião da editoria fica clara com a escolha para inaugurar a revista de estreia de obras de autores conhecidos no mundo jornalístico e literário, que gerariam interesse no público leitor: as crônicas Rosas Vermelhas, de Rubem Braga, Um anúncio, de Graciliano Ramos e Depoimento, de Marques Rebelo. Este último escritor teve a partir da década seguinte seu nome consolidado junto à crítica e ao público, alcançando prestígio no mundo da literatura. "Hoje esquecido, Rebelo chegou a ser considerado pela crítica de seu tempo como o quarto e último de uma linha sucessória de ficcionistas cariocas, que teria se iniciado com Manuel Antônio de Almeida, passando por Machado de Assis e Lima Barreto” (SOUZA, 2012:1).

Os outros números também apresentam em suas primeiras páginas a obra de autores prestigiados na literatura modernista e ligados ao PCB: abrem o número dois três poetas já famosos nos circuitos modernistas do Rio de Janeiro e São Paulo: Manuel Bandeira, Álvaro Moreyra e Carlos Drummond de Andrade; o terceiro é aberto com um poema de Rossine Camargo Guarnieri - que estava naquele ano lançando o livro Porto Inseguro, prefaciado por Mário de Andrade -, um conto 
do já consagrado escritor Érico Veríssimo e um poema de Drummond; o sexto é aberto por textos de Álvaro Moreyra e Telmo Vergara, escritor pouco lembrado hoje em dia, conterrâneo de Érico Veríssimo, cuja obra, principalmente após ter vencido o prêmio Humberto Campos promovido pela José Olympio Editora em 1936, era na época conhecida não apenas no Rio Grande do Sul, mas em todo o Brasil. O sétimo começa com o poema Era uma vez uma menina sádica, do então prestigiado escritor católico, que no período dialogava com o surrealismo, Jorge de Lima, que naquele ano estava lançando o livro de poemas A túnica Inconsútil; e por fim abre o oitavo número o conto Noite de Caes, do já prestigiado escritor Jorge Amado.

Mas muitos outros autores de diferentes tendências literárias ocupam as páginas da Esfera. A disposição aparentemente aleatória dos artigos, ilustrações, poemas e contos na revista, sem relação estética um com os outros, atesta um aspecto de improviso, deixando entrever que fatores como amizade e afinidade política se sobrepuseram muitas vezes à análise estética na hora da edição. Este deve ser um dos motivos pelos quais Mário de Andrade, debatendo as críticas que o português Adolfo Casais Monteiro fez à Esfera no artigo Sobre um pseudo órgão do intercâmbio Luso Brasileiro ${ }^{58}$, não defende o seu mérito e, ao compará-la à Revista do Brasil ${ }^{59}$, que também circulava entre Brasil e Portugal, a toma por um periódico de menor importância (ANDRADE, 1972:66).

\section{4 - Literatura, regionalismo e romance social}

O Rio de Janeiro, que desfrutava desde os tempos do império da proximidade com o governo central, e São Paulo, que enriquecida com o café e a industrialização se tornara o centro econômico do País possuíam uma imprensa de alcance nacional que as colocava no centro da vida cultural brasileira. A Semana de Arte Moderna de 1922, consagrada ao longo dos anos como marco inaugural da arte moderna no Brasil, é a expressão da modernidade de São Paulo e do alcance de sua imprensa, ocupada em grande parte por integrantes do movimento modernista (SIMIONI, 2014), mas ao longo das décadas de 1920 e 30, eventos, debates e publicações sobre a arte e literatura moderna fizeram parte da vida de intelectuais e artistas de diferentes tendências e eclodiram com diferentes características em cidades do Norte ao Sul do País.

\footnotetext{
${ }^{58}$ Presença, a.11, v.3, Coimbra, novembro, 1938:29 - 30.

${ }^{59}$ Revista fundada em 1916 por Júlio de Mesquita Filho e vendida em 1918 a Monteiro Lobato, seu único proprietário até 1926. "A revista foi então adquirida por Assis Chateaubriand, que a relançou em três oportunidades: de 1926 a 1927 , período considerado sua segunda fase, na qual foram publicados nove números; de 1938 a 1943, terceira fase, em que foram publicados 56 números; e em 1944, quarta fase, na qual foram lançados três números. Acrescente-se, ainda, o ressurgimento proposto por Darci Ribeiro entre os anos de 1984 e 1990, a quinta fase, na qual foram publicados 12 números”. In: REVISTA DO BRASIL, CPDOC - FGV, Verbete Temático.
} 
Esta diversidade está representada na Esfera por reunir em suas páginas obras de escritores e artistas que tinham como principal vínculo a adoção da posição política antifascista. Ela reúne trabalhos de intelectuais que se vinculavam ao modernismo paulista, como Oswald de Andrade, Álvaro Moreyra, Carlos Drummond de Andrade e Manuel Bandeira e de integrantes de outros grupos e associações modernistas que se formaram durante as décadas de 1920 e 1930 pelo País.

Em Belo Horizonte, as características particulares dos modernistas, representados na Esfera pelos poemas $O$ cotovelo que dói e o conto A Noite Dissolve os Homens, de Carlos Drummond de Andrade, são tema do livro Cenas de um modernismo de província - Drummond e outros rapazes de Minas, de Ivan Marques ${ }^{60}$. Segundo Schefell, em artigo sobre este livro,

[...] a rapaziada de Minas, expressão cunhada por Humberto Werneck (1992), produziu uma literatura que não conseguiu ocultar a saudade da roça convivendo com o desejo do elevador, como sintetizam com precisão os versos de Drummond. Daí o caráter peculiar desse modernismo periférico, que não foi um "futurismo de província", mas um modernismo desconfiado, por um lado inquieto, com desejos reformistas e revolucionários, e de outro neutralizado pela "vida besta".

Carlos Drummond de Andrade vivia há quatro anos no Rio de Janeiro e já mantinha desde o início da década, enquanto estudante em Belo Horizonte, contato próximo com os modernistas de São Paulo. Neste período liderava na capital de Minas Gerais o Grupo do Estrela, formado por universitários e recém-formados que se reuniam no Café Estrela, entre eles Pedro Nava, Alberto Campos, Milton Campos e Emilio Moura. A aproximação deste grupo com os intelectuais da Semana de 22 se intensificou a partir de 1924, quando recebeu a visita da conhecida Caravana Paulista, formada por Mário de Andrade, Oswald de Andrade, Olívia Guedes Penteado, Tarsila do Amaral e Godofredo Teles, que acompanhavam o poeta suíço-francês Blaise Cendars em viagem ao Rio de Janeiro e cidades históricas de Minas Gerais. Após este encontro, Carlos Drummond de Andrade estreitou a relação com os modernistas paulistas.

Grande parte dos colaboradores que escreveram de São Paulo participaram das rodas do Grupo Baruel, uma agremiação que se formou em torno do escritor mineiro Amadeu de Queiroz, farmacêutico chefe da Baruel, uma das mais conceituadas drogarias da cidade. Neste estabelecimento poetas e escritores, muitos vindos de outras localidades do País, também se encontravam em reuniões onde, segundo Amadeu de Queiroz, debatia-se muito, principalmente literatura: "De tudo se tratou

${ }^{60}$ MARQUES, Ivan. Cenas de um modernismo de província - Drummond e outros rapazes de Minas. São Paulo: Editora 34, 2011. 
ali: artes, letras, ciências, política, religião, crítica, maledicência, amor, esporte, folclore, livros, literatura e mais literatura" ${ }^{1}$. Destes encontros surgiu, em 1939, o periódico Roteiro, Quinzenário de Cultura, que em seu editorial se apresentava como uma publicação de uma nova geração de modernistas paulistas (D’ONOFRIO, 2017).

De Belém do Pará, cidade moderna que se desenvolveu no meio da floresta Amazônica durante o ciclo econômico da borracha, e que com Manaus era o centro da vida comercial e cultural da região Norte, escreveu Raymundo de Moraes, o mais velho belenense a colaborar com a Esfera, publicando A Floresta, capítulo inédito de seu romance Ressuscitados: Romance de Purús. O autor foi um dos grandes etnógrafos da Amazônia nos primeiros anos do século XX e representa uma mudança de visão sobre a Amazônia, que incorpora a busca dos modernistas pela identidade nacional nas tradições regionais pois, segundo Guimarães, mesmo ainda influenciado pelo pensamento cientificista do início do século XX, reconhece a importância do imaginário nativo (GUIMARÃES, 2015). Como ele mesmo disse:

Apesar, todavia, das observações científicas dos naturalistas, que rasgam véus da História Natural, a lenda entremeia-se à vida do homem, rodeando-lhe de mistério os passos e a crônica" (MORAES, 2000 apud GUIMARÃES, 2015:5).

Antes da semana de 1922, já existia em Belém uma imprensa que dialogava com as ideias da modernidade: Oswaldo Orico e Peregrino Junior, colaboradores da Esfera, escreviam na revista literária Guajarina, fundada em 1919 pela editora do mesmo nome. No editorial de seu primeiro número a Guajarina se apresentava como um "periódico moderno, leve, galante, fino, esvoaçante, brejeiro, que, num afã bisbilhoteiro incansável, tudo vê, tudo escuta, tudo diz...” (SALLES, 1971:88 - 89).

Durante a década de 1920, modernidade e regionalismo na Amazônia também entraram em diálogo com o modernismo paulista através da grande imprensa e de periódicos voltados à literatura. Um deles foi a revista Belém Nova, criada em 1923 e dirigida pelo poeta anarquista Bruno de Menezes, que circulou durante seis anos na cidade, recebendo colaborações de escritores e jornalistas do Rio de Janeiro, São Paulo e outras capitais, entre eles os colaboradores maranhenses da Esfera, Abguar Bastos e Eneida de Moraes (PAIVA, 2008).

${ }^{61}$ QUEIROZ, Amadeu de. Manicuera. Manuscrito inédito. Fundo Amadeu de Queiroz, Academia de Letras, São Paulo. Obras raras, pasta 13.2, doc 03, p. 15 - 17 (D’ONOFRIO, 2017). 
Abguar Bastos, membro da ANL e opositor ao Estado Novo, formado em Direito pela Faculdade do Amazonas, mantinha constante diálogo com os paulistas Oswald de Andrade, Raul Bopp e Mário de Andrade e foi um dos responsáveis pela divulgação do modernismo paulista no norte do país. Publicou em 1926 na revista Belém Nova o manifesto Flaminaçu (grande chama, em Tupi), inspirado no manifesto Pau Brasil, de Oswald de Andrade, propondo uma reformulação das posições tradicionalistas dos escritores da região, o estudo dos temas da realidade e do folclore amazônico e convocando "os intelectuais paraenses para o movimento modernista de São Paulo, que na Amazônia deveria ganhar feições próprias, dadas as peculiaridades da própria natureza". (PAIVA, 2008: 178). Mais de dez anos depois publicou na Esfera o conto Matei um homem, que finaliza com uma imagem de desesperança:

\footnotetext{
Sinto gue os meus remorsos não bastam para acalmar-me. Estou, mesmo, lucidamente decidido! Vou matar outro homem, isto é, outros dos meus personagens, neste romance que estou começando a escrever. Vou aproveitar lhe a vida, explorando the os sentimentos, roubando-lhe os segredos da alma e depois, ainda por necessidade da minha arte chupar-lhe o sangue, como um morcego. É doloroso. Mas de tudo o homem é capaz, principalmente quando começa a acreditar em fantasmas, já cansado de acreditar nos homens ${ }^{62}$.
}

Nas capitais do Nordeste, que sofriam com a seca e decadência econômica, os intelectuais apresentaram na década de 1920 e 30 um projeto estético similar ao do Norte do País, que se opunha tanto ao academicismo quanto à mera tradução do modernismo da semana paulista de arte moderna para as realidades locais, buscando preservar e fortalecer as tradições da região. O movimento regionalista, liderado por Gilberto Freyre, se concretizou com a publicação de seu Manifesto Regionalista em 1926 e se alastrou por todo o Nordeste. Segundo Ferreira, o movimento regionalista

[...] caracteriza-se como um momento de ampla expressão cultural e estética com forte inserção na literatura brasileira, cujo produto final são as bases para o chamado romance regionalista da década de trinta" (FERREIRA, 2008: 23).

Recife foi um dos maiores polos impulsionadores dos debates e divulgação do modernismo regionalista do Brasil. A literatura produzida por pernambucanos está representada na Esfera por três gerações de escritores, com cinco poemas, dois contos, uma crítica literária, uma crônica e um capítulo de romance.

\footnotetext{
${ }^{62}$ Esfera, Rio de Janeiro, n. 3:56.
} 
Segundo Ângelo Barroso Costa Soares, na Bahia, Aydano do Couto Ferraz, Dias da Costa, Jorge Amado, José Alves e Edison Carneiro haviam integrado o grupo de jovens intelectuais e artistas, que no final da década de 1920 se reuniam em cafés e bares de Salvador "para comentarem o dia- $a$ dia da cidade da Bahia, os escândalos de toda ordem, discutirem literatura, as novas revistas ou as pelejas entre os intelectuais através dos jornais" (SOARES, 2006:80) e que criaram, em 1930, a Academia dos Rebeldes, uma agremiação que representa o momento inaugural do romance regionalista baiano. Em 1938, todos os integrantes da Academia dos Rebeldes que colaboraram com dezenove artigos na Esfera, eram filiados ou militantes do Partido Comunista do Brasil (Idem, 2006).

Na Academia dos Dez Unidos, criada por estudantes de Maceió, e no Grêmio Literário Pereira Passos, fundado em 1927 por escritores e jornalistas da cidade, se reuniam em debates e eventos sobre literatura "nomes como os dos alagoanos Jorge de Lima, Aurélio Buarque de Holanda, Manuel Diegues Junior e o paraibano José Lins do Rego, que na época vivia em Maceió” (ÁVILA, 2009:61). Entre o final da década de 1920 e o início da de 1930, moravam e conviviam com estes intelectuais nesta pequena cidade, com cerca de 90 mil habitantes, Graciliano Ramos, Rachel de Queiroz, o artista plástico e crítico de arte Santa Rosa e outros menos conhecidos, como Aloísio Branco, Alberto Passos Guimarães, Carlos Paurílio e Valdemar Cavalcanti ${ }^{63}$. A cidade sediou o evento liderado por José Lins do Rego e reconhecido como precursor do modernismo em Alagoas, a Festa da Arte Nova (junho/1928), que apresentou um programa com música, danças, vestuário e costumes locais de cunho popular e regionalista, e Canjica Literária (1929), uma festa caipira, com os participantes vestidos à caráter, animada e ornamentada com música e artefatos caipiras (SILVA, 2011).

Em São Luiz do Maranhão a Sociedade Literária Cenáculo Graça Aranha, que tinha como patrono um dos organizadores da Semana de Arte Moderna de 1922, o escritor patrício falecido no ano anterior, Graça Aranha, foi criada em 1932 por estudantes, entre eles Oswaldino Marques Ribeiro, que publicou na Esfera o artigo Un conteur ${ }^{64}$. A associação tinha por objetivo promover a literatura do estado difundindo nomes e obras esquecidas, além de reunir a juventude em torno das ideias modernistas, através da promoção de eventos de arte e literatura, como Horas de Inverno, promovido pelo Casino Maranhense de São Luiz ${ }^{65}$ e as Horas de Arte e Literatura promovidas semanalmente por cerca de um ano. As atividades do grupo, que tinha em seu programa o combate

\footnotetext{
${ }^{63}$ RUFFATO, L. Maceió, 1930. Rascunho, n 100. Disponível em: <http://rascunho.com.br/maceio-1930-2/>. Acesso em 20/03/2018.

${ }^{64}$ Crítica ao livro Canções do Beco, do autor baiano Dias da Costa (COSTA, D. Canções do Beco, editora Rumos, Rio de Janeiro, 1939).

${ }^{65}$ HORAS de Inverno. O Imparcial, São Luiz do Maranhão, 13/07/1931:Capa.
} 
ao analfabetismo, foram publicadas várias vezes no jornal $O$ Imparcial, que manteve para isto um espaço especial ${ }^{66}$.

Em Porto Alegre, que na década de 1920 era o centro econômico e político do terceiro estado brasileiro mais industrializado do Brasil e, a partir das últimas décadas do século XIX, desenvolvera uma imprensa atuante e diversa, em constante diálogo com São Paulo e Rio de Janeiro, o debate modernista era próximo ao dos modernistas de São Paulo. A livraria e editora $O$ Globo, criada na cidade em 1883 e ampliada em 1928, também favoreceu o crescimento do mundo literário local. Érico Veríssimo e Athos Damaceno, colaboradores da Esfera, fizeram parte do grupo de jornalistas, artistas e literatos, entre eles Augusto Meyer, Moysés Vellinho, Viana Moog, Mário Quintana e Rui Bopp, que nas décadas de 1920 e 30 frequentava o Café Colombo para discutir e fazer política, literatura social e arte moderna.

Nos anos trinta, as diferentes tendências modernistas que se manifestavam no País incorporaram o discurso sócio-político ao seu projeto original, dando origem ao movimento artístico que perdurou até a década de 1970 e ficou conhecido como arte e literatura social. Esta opção dialogava com o projeto político da esquerda brasileira, na época representado pelo Partido Comunista do Brasil.

$\mathrm{Na}$ literatura, desde a década anterior, acompanhando o crescimento do mercado editorial, proliferaram-se romances tratando de problemas sociais de diferentes regiões do País. Conhecido como Romance de trinta, o movimento alcançou repercussão nacional e internacional e deixou o nome de escritores como Graciliano Ramos, Rachel de Queiroz, Jorge Amado e Érico Veríssimo consagrados na história da literatura brasileira. Além deles, outros autores prestigiados e vendidos na época, mas hoje esquecidos, estão representados na revista com contos, trechos de livros, crônicas e poemas, abordando temas relacionados à modernidade e urbanização, manifestações culturais tradicionais, afro-brasileiras e regionais e problemas sociais específicos dos seus locais de origem. Em seus primeiros oito números a revista publicou na área de literatura oitenta e sete poemas, quarenta e dois contos, sessenta e um artigos sobre literatura, trinta e nove críticas literárias, catorze crônicas e catorze capítulos de livros.

${ }^{66}$ O jornal O Imparcial, disponível online na Hemeroteca Nacional, foi fonte para as informações sobre o Cenáculo Graça Aranha. 
A Esfera publicou dois artigos sobre música, treze sobre teatro, sete críticas e sete artigos sobre artes visuais e vinte e oito ilustrações, além de informações e comentários em todos os números sobre as últimas novidades do teatro, rádio e cinema em diversas localidades do Brasil e do exterior.

Além dos programas musicais comentados na coluna Rádio, a música foi tratada na revista em três artigos: O Cravo de Mozart é eterno, de José Lins do Rego, O sentido nacionalista da obra de Carlos Gomes, de Waldemar de Oliveira e a crônica Strauss cerveja e sono, de Athos Damasceno.

O primeiro faz uma abordagem que relaciona a tradição representada pelas obras de Mozart com a política e Waldemar, ao falar sobre a obra do brasileiro Carlos Gomes, destaca seu sentido nacionalista como um componente do modernismo que despontou na música ainda em meados do século XIX. Dedica a ele as mesmas palavras com as quais o modernista Ronald de Carvalho se referiu ao poeta Gonçalves Dias:

Foi ele, sem dúvida, a primeira voz definitiva da nossa poesia, aquele que nos integrou na própria consciência nacional, que nos deu a oportunidade venturosa de olharmos, rosto a rosto, nossos cenários físicos e morais. Nesse homem pouco vulgar palpita, com inigualável intensidade a luz dos nossos horizontes, a limpidez de nossos céus e o sonoro fragor de nossos rumorosos rios.

O movimento de renovação no teatro iniciado no Rio de Janeiro na década anterior e presente na vida de Sylvia e Maria Jacintha desde a juventude, nos tempos das Horas de Arte promovidas pelo Athenée Club em Niterói, havia incorporado no final da década de 1930 a vertente social, que entrou em cena em 1932: em São Paulo com a peça Andaime, de Paulo Torres e no Rio de Janeiro com Joracy Camargo estreando Deus lhe Pague.

Principal área de atuação de Maria Jacintha, diretora da revista, o teatro foi abordado através de críticas a peças em cartaz no Rio de Janeiro e da publicação de trechos de textos teatrais. Seu texto de estreia $O$ Gosto da Vida, escrito em 1937, cuja décima cena do primeiro ato foi publicada na Esfera (até hoje não foi publicado na íntegra, como grande parte de seu trabalho), rendeu-lhe o $1^{\circ}$ Prêmio de Teatro da Academia Brasileira de Letras em 1938, mesmo tendo sido "censurado e retirado de cartaz, por tratar de tema considerado, na época, atentatório à moral e aos bons costumes" (RODRIGUES, 2007: 1). A Esfera também publicou Três Momentos de uma estrada que sobe (trechos de sua peça A Estrada que sobe, nunca encenada). Sua temática nesta primeira fase andava em compasso com o 
romance de trinta e o teatro social, além de destacar "a figura feminina engajada em seu tempo $e$ dona de seus anseios e destino" (RODRIGUES, 2007: 6).

Além destas transcrições, Maria Jacintha escreveu na coluna os artigos Teatro Rival - A Marquesa de Santos (peça também comentada na revista por Eneida) e Tiradentes, ambas teatro histórico de Viriato Corrêa; Yayá Boneca, peça de Ernani Fornan e Teatro, comentando outras peças em cartaz no mês anterior.

Eneida também assinou duas matérias na coluna Teatro: O homem que nasceu duas vezes, peça de Oduvaldo Viana e A Marqueza de Santos, de Viriato Corrêa. Ambos os autores atuaram na renovação do teatro brasileiro das primeiras décadas do século XX. Fundaram em 1921, sete anos antes do Teatro de Brinquedos de Eugênia e Álvaro Moreyra, com Abigail Maia e Nicola Viggiani “um grupo considerado inovador da linguagem teatral, já que se propunha a criar uma dramaturgia voltada para assuntos brasileiros e com prosódia e autores brasileiros" (GOMES, 2018: 676).

Assinados com a inicial E., e provavelmente de sua autoria, são os artigos sobre os filmes exibidos no Rio de Janeiro aquele ano: Emile Zola, tratando da superprodução da Warner estrelada por Paul Muni, que reinaugurou com enorme sucesso o Cine Brodway; Felicidade de mentira, com Joan Crowford, Robert Young e Franchot Tone, filme que foi um fracasso de crítica e bilheteria; Madame Waleska, outro sucesso exibido no Cine Metro, produzido pela Metro Goldwin Meyer, com Greta Garbo e Charles Boyer; No theatro da vida, dirigido por Gregpry La Cava, com a interpretação de Katherine Hepburn, Ginger Rogers e Adolphe Manjou e Rainha Vitória, distribuído pela RKO Rádio Pictures, produzida e dirigida por Herbert Wileox, estrelando Anna Neagle.

Sem autoria, na coluna Teatro, mas escritas provavelmente por Maria Jacintha, Eneida ou Sylvia, foram publicadas críticas às peças Fora da Vida, de Joracy Camargo, cuja estreia nos palcos cariocas se deu aquele ano, Baile de Máscaras, de Henrique Pongetti e Luis Martins; Fontes Luminosas (1937), de George Berr e Louis Verneuil, encenadas pela Companhia Dulcina Odilon e o artigo Zazá, Dulcina Odilon e outros comentários. ${ }^{67}$

Além de artigos de Maria Jacintha, Eneida e sem autoria, outros dois autores escreveram sobre o tema: o argentino José Maria Monner Sans, militante de esquerda em seu país, que fez uma crítica a Ermeto Zacconi (celebridade internacional nas duas primeiras décadas do século, que em 1938, aos 82 anos fez uma turnê no Brasil) e o jornalista pernambucano Lucilo Varejão, que publicou o artigo Samuel Campelo, sobre o dramaturgo pernambucano que fundou o Grupo Gente Nossa, precursor do

\footnotetext{
${ }^{67}$ As informações sobre filmes e peças em cartaz são provenientes das matérias na Esfera e de anúncios e críticas de filmes em jornais do Rio de Janeiro no ano de 1938, consultadas na Biblioteca Nacional Digital.
} 
modernismo teatral no Recife ${ }^{68}$. Lucilo, membro da companhia, foi também escritor e crítico de arte atuante na Capital de Pernambuco. O vínculo do grupo com a revista não se resume a esta publicação: a Esfera também recebeu duas colaborações de Waldemar de Oliveira, outro recifense integrante do Gente Nossa, que escreveu o citado artigo sobre Carlos Gomes e uma crítica sobre o romance $O$ Lobo e a Ovelha, de Lucilo Varejão ${ }^{69}$.

As artes visuais foram representadas com críticas e artigos sobre movimentos artísticos, artistas e exposições e com a publicação de reproduções de gravuras e pinturas de artistas modernistas, ligados à arte social.

Diferente do que ocorreu com a literatura social, que no início da década de 1930 já havia atingido um grande público leitor, a arte moderna ainda lutava no final da década contra o academicismo das escolas de belas artes. O ensino acadêmico, no entanto, enfrentava desde o final do século dezenove a resistência de professores e alunos, e

\begin{abstract}
[...] trabalhos de extração mais ou menos renovadora começam a ganhar exposição na cidade nas edições do Salão da Primavera, ocorridas no Liceu de Artes e Ofícios, entre 1923 e 1925, ao lado de obras que obedeciam aos padrões aceitos pela academia. As mostras individuais de modernistas adquirem alguma regularidade entre 1928 e 1929, ainda assim em galerias e situações improvisadas (RIBEIRO, 2009: 18).
\end{abstract}

Passados dez anos, em 1938, os modernistas do Rio de Janeiro ainda empenhavam-se por espaços expositivos e criavam movimentos e associações paralelas ao ensino oficial para divulgar suas obras e ideias, que só vieram a ter um lugar no mais importante evento artístico do País, o Salão Nacional de Belas Artes promovido pela ENBA, em 1940, ano que foi criada uma divisão moderna na exposição.

No Rio de Janeiro, a Associação dos Artistas Brasileiros, citada em diversos artigos da Esfera, atuava há nove anos na cena cultural da cidade, reunindo prestigiados músicos e artistas visuais, como Di Cavalcanti (Rio de Janeiro, 1897 - 1976), Cândido Portinari (Brodowski, 1903 - Rio de Janeiro, 1962), Tomás Santa Rosa (João Pessoa, 1909 - Nova Delhi, 1956) e Heitor Villa Lobos (Rio de Janeiro, 1887 - 1959). Fundada em 1929 pelo acadêmico Celso Kelly, que na época, nove anos depois da sua fundação, ainda ocupava o cargo de presidente, promovia em sua sede no Palace Hotel, na Cinelândia, palestras, concertos e exposições de arte.

\footnotetext{
${ }^{68}$ Samuel Carneiro Rodrigues Campêlo (Engenho Arimunã Escada PE 1889 - Recife PE 1939). Autor, ator, libretista, animador cultural e historiador". In: Enciclopédia Cultural Itau.

${ }^{69}$ VAREJÃO, Lucilo. O lobo e a ovelha, Recife: Casa Mozart, 1935, $1^{\text {a }}$ edição.
} 
Esta associação foi criada durante o Salão dos Artistas Brasileiros organizado por Celso Kelly, que reunindo artistas jovens e consagrados, acadêmicos e modernos, visava aproximar a arte moderna da ENBA, a mais importante instituição legitimadora das artes plásticas no Rio de Janeiro. A organização deste evento conseguiu o apoio do ministro da justiça, Dr. Vianna do Castelo, que cedeu a Biblioteca Nacional para sediar a exposição e, no seu encerramento, homenageou o ministro das Relações Exteriores, Octávio Mangabeira, o que significava uma aproximação da arte e de artistas não acadêmicos com o maior financiador da cultura, o governo federal ${ }^{70}$. Segundo anunciou o jornal A Noite, o Salão dos Artistas Brasileiros de 1929

[...] consiste em um amplo salão, sem diretores nem censores, nem júris, mas eminentemente de artistas, onde todos têm os mesmos direitos, podendo intervir livremente no que respeita a sua própria participação, sem que, todavia, possam influir em trabalhos alheios. [...]. As preferencias estéticas, por mais diversas que sejam ou por mais estranhas que se apresentem ali encontrarão acolhida e serão grupadas, obedecendo tanto quanto possível as intenções dos próprios artistas. ${ }^{71}$

Outra associação de artistas cariocas, da qual participaram os artistas Paulo Werneck e Jarbas Andrea, ativos militantes do PCB e colaboradores da Esfera, foi o Clube de Cultura Moderna do Rio de Janeiro, fundado em 1935 e filiado à Aliança Nacional Libertadora. Esta associação

\footnotetext{
Constituiu uma frente ampla política integrada por escritores e jornalistas liberais, socialistas e antifascistas, [...]. Seus objetivos eram "estudar e divulgar entre as massas as diretrizes modernas do pensamento humano". Sua atuação concentrou-se na promoção de conferências e debates. O clube foi extinto com a instalação do Estado Novo, quando muitos de seus integrantes foram presos. ${ }^{72}$
}

A primeira tentativa de organizar uma exposição de pinturas e desenho de motivos sociais, iniciativa de Aníbal Machado, Álvaro Moreyra e Thomás Santa Rosa, foi promovida pelo Clube de Cultura Moderna no ano de sua fundação. Aníbal Machado, em célebre palestra proferida por ocasião do encerramento da exposição, esclarece os princípios dos artistas envolvidos, que nortearam sua realização:

\footnotetext{
${ }^{70}$ O Jornal, Rio de Janeiro, 10/9/29:3.

${ }^{71}$ Pelo Florescimento da arte nacional. A Noite, Rio de Janeiro, 12/08/1929.

${ }^{72}$ CLUBE DA CULTURA MODERNA. Alzira Alves de Abreu. In CPDOC FGV, Verbete Temático.
} 
Existem diferenças fundamentais entre o espírito desta exposição e daquelas que estamos habituados a visitar. Se o povo a esta compareceu, foi à procura das imagens que lhe pertencem na obra dos artistas que mais fielmente o interpretam. Aqui, uma arte objetiva, realista, popular - a vida cotidiana do homem em seu meio e em seu tempo. Lá, as telas luxuosas, a parada de nudezas que o povo sorri, não porque lhe falte o gosto das formas que lhe agradam a vista e falam as forças criadoras do instinto, mas porque as reconhecem deturpadas pelo requinte dos estetas para gozo e uso de uma classe viciada [...] ${ }^{73}$

A exposição reuniu em sua maior parte trabalhos gráficos de Goeldi, Noêmia, Di Cavalcanti, Portinari, Santa Rosa, Hugo Adami, Waldemar da Costa, Paulo Werneck, Ismael Nery, Guignard, Alcides Rocha Miranda, Teruz, Toledo, J. Barboza, Carlos Leão, entre outros. Segundo Aracy Amaral, quando comenta a exposição e a palestra de Aníbal Machado,

O público poderia estranhar a ausência de pintores ("não obstante as amostras gráficas de Portinari, Hugo Adami, nomes já conhecidos e de Waldemar Costa"), "mas em exposição de arte social como esta, era natural que fossem convocados os artistas do desenho e da gravura”. A tradição vem de longe, e o autor menciona a Daumier, Goya, Forain, Grosz, Kaethe Kollwitz, Lingner (sic) e Masereel, artistas "que se voltaram de preferência para a realidade cotidiana, para os costumes do povo, utilizando-se dos meios gráficos mais simples e diretos para a reportagem social e para a sátira política. É por todos reconhecida e proclamada a tradição revolucionária do desenho e da gravura, afirma o conferencista. (AMARAL, 2003: 51)

A cena das artes visuais de São Paulo está representada na Esfera por artigos de Geraldo Ferraz e Flávio de Carvalho e pela ilustração de Oswald de Andrade Filho (Figura 29).

Flávio de Carvalho, fluminense residente em São Paulo, foi com Antônio Gomide, Di Cavalcanti e Carlos Prado, um dos criadores do Clube dos Artistas Modernos, em 1932. A associação, que ficou ativa durante dois anos, se proclamava "aberta à participação de todos os artistas", mesmo os que não se vinculavam ao modernismo da "aristocracia paulistana liderado por Mário de Andrade", e tinha como objetivo inicial em seus estatutos a promoção de reuniões, conferências e exposições, a assinatura de revistas sobre arte, formação de uma biblioteca e a defesa dos interesses da classe (AMIN, 2011). Suas atividades artísticas basearam-se em experimentações de novas linguagens dentro da estética modernista, e na união da arte à política, visando a divulgação da

\footnotetext{
${ }^{73}$ MACHADO, Aníbal. Mostra de arte social. Movimento, Rio de Janeiro, n.4:19-23, out. 1935
} 
ideologia de esquerda (FORTES, 2008). Assim como o Grupo Baruel e seu quinzenário, representa a tensão entre diferentes manifestações modernistas em São Paulo.

Mil novecentos e trinta e oito foi também o ano da criação da Associação Rio-grandense de Artes Plásticas Francisco Lisboa, em Porto Alegre, que tinha por finalidade promover as artes visuais, defender os interesses de seus membros perante a sociedade e realizar mostras de artes visuais independentes do Instituto Livre de Belas Artes do Rio Grande do Sul, pois esta instituição, hegemônica no restrito ambiente artístico de Porto Alegre, raramente aceitava artistas não formados por ela nas exposições de arte que promovia. Carlos Scliar, que publicou na Esfera o desenho Chinês (figura 25), fez parte da equipe inauguradora da Associação. Filho de um dos fundadores do partido comunista em Porto Alegre, tinha 19 anos de idade e conhecimentos de artes plásticas adquiridos em aulas particulares no departamento gráfico da editora $O$ Globo. Assim como outras editoras, a empresa oferecia instrução técnica de desenho e artes gráficas para seus funcionários e colaboradores, que passaram a disputar espaço no mundo das artes com os acadêmicos do instituto. Segundo Ramos, eram estes artistas, e não os acadêmicos, que desde meados da década anterior promoviam o debate sobre arte moderna no Estado (RAMOS, 2013), corroborando a citada afirmação de Aníbal Machado sobre a tradição revolucionária do desenho e da gravura.

O Grupo dos Independentes, do Recife está representado na Esfera por Percy Lau, Luis Soares e Augusto Rodrigues. Integrado por artistas vinculados à imprensa e ao movimento regionalista, surgiu em torno de duas exposições de belas artes, o Salão dos Independentes de 1933 e 1936, promovidas no Recife, reunindo acadêmicos e modernos. Além dos citados colaboradores da Esfera, participavam da agremiação Bibiano Silva, Carlos Holanda, Danilo Ramirez, Francisco Lauria, Hélio Feijó, Elezier Xavier, Nestor Silva e Manoel Bandeira. (DIMITROV, 2013). 


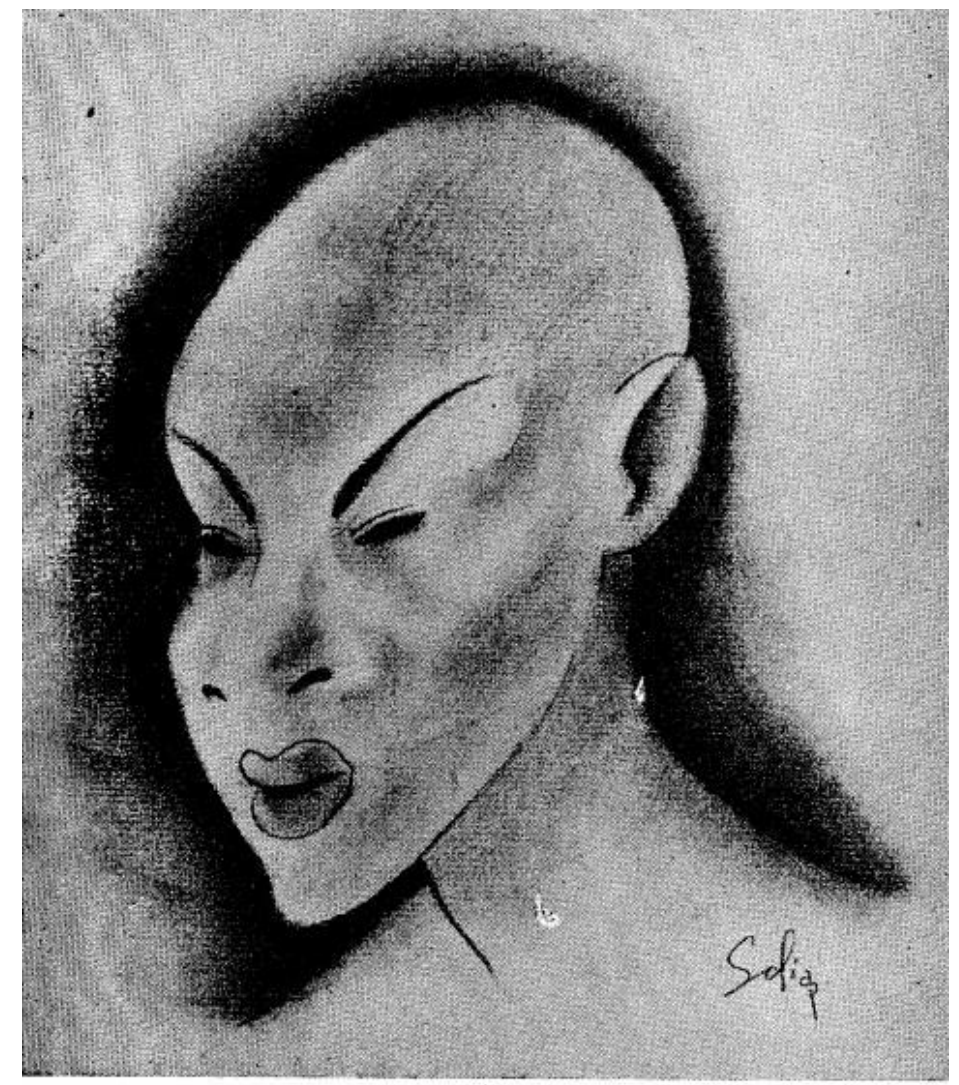

\section{Carlos Scliar - Chinês}

Figura 31 - Carlos Scliar, Chinês, c. 1938. Desenho. Reproduzido na Esfera 8: 9

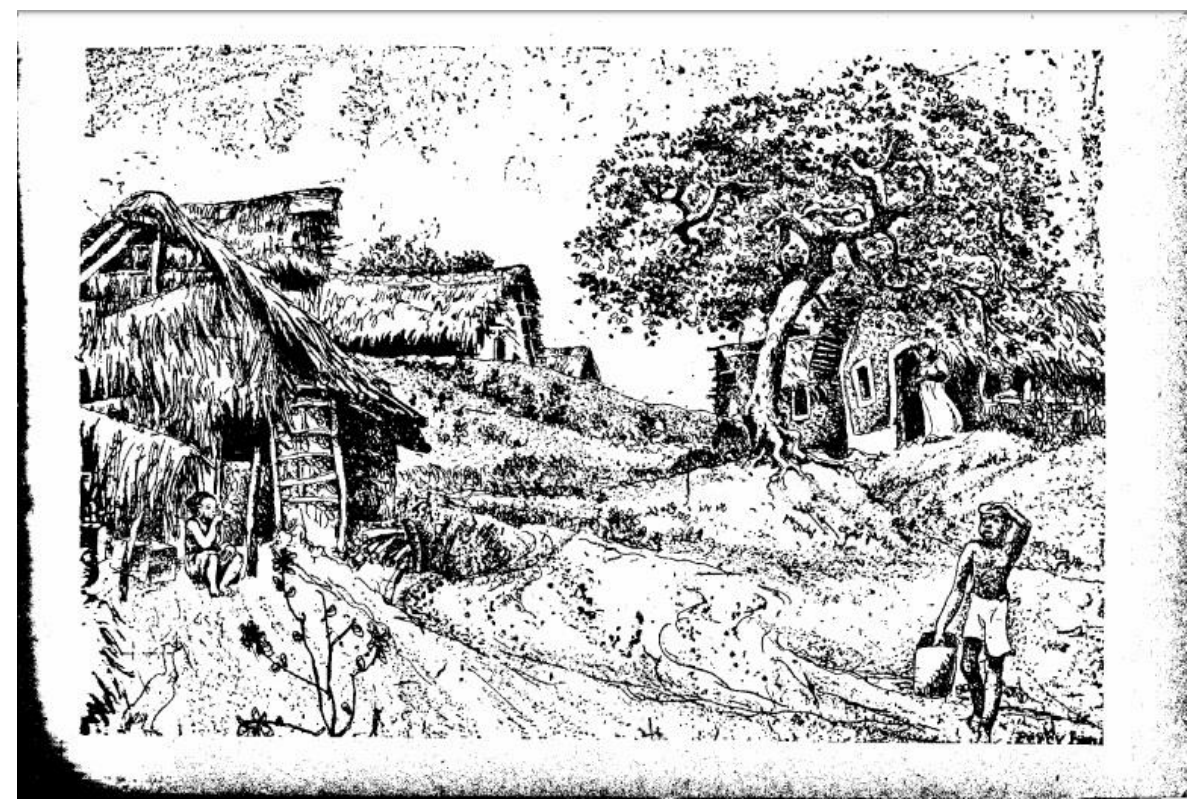

Figura 32 - Percy Lau, sem título, c. 1938. Xilogravura. Reproduzida na Esfera 4, 17 
Eduardo Dimitrov em sua tese de doutorado, Regional como opção, regional como prisão: trajetórias artísticas do modernismo pernambucano (Idem, 2013), realizou um importante estudo sobre o modernismo pernambucano nas artes visuais.

O evento artístico mais representado na revista foi o Salão de Maio, organizado em 1937, 1938 e 1939 por Flávio de Carvalho, Geraldo Ferraz, Madeleine Roux, Paulo Ribeiro de Magalhães e Quirino da Silva no Grill Room do Hotel Esplanada, em São Paulo. Com o patrocínio da elite paulista e o apoio do Departamento Municipal de Cultura chefiado na época por Mário de Andrade, a mostra de 1938 trouxe pela primeira vez ao cenário artístico do País o debate entre figurativos e abstracionistas, através da exposição de obras de abstracionistas estrangeiros e de conferências sobre arte que ganharam destaque nos jornais e revistas do período (CARDOSO, 2005).

$\mathrm{Na}$ apresentação do catálogo da $2^{\mathrm{a}}$ exposição, em 1938, Jorge Amado, que participou da organização e escolha dos artistas mexicanos, fala sobre a iniciativa:

A pintura, a escultura, a arquitetura, eis aí três abandonados no Brasil. Um triunfo absoluto do academismo nas artes plásticas. O Salão de Maio rompeu esse ambiente com a sua mostra de 1937. A de 1938, muito mais importante, selecionada, internacional, viva, contendo as mais diversas tendências das artes plásticas modernas, é a vitória definitiva. $\mathrm{O}$ sucesso do Salão de Maio representa o melancólico enterro dos salões acadêmicos. E prova uma coisa que eu considero importantíssima: que o público, falo do grande público que não entende de técnica de pintura, mas vê, sente e se emociona, reage de um modo favorável aos artistas modernos expostos pelo Salão de Maio. Terminou a época dos risinhos. Existe um ambiente de compreensão. Criar esse ambiente tem sido a grande tarefa do Salão de Maio. ${ }^{74}$

Nos oito números foram publicados dez artigos sobre artes visuais, sendo que quatro são de autoria de Silvia. Na revista número dois, de junho de 1938, ela escreveu sobre a exposição de aquarelas, litografias e gravuras de artistas europeus promovida pela Associação dos Artistas Brasileiros, entre eles Frans Masereel com quem fez contato e que colaborou com a Esfera, mas também Picasso, Cézanne, Vlaminck, Renoir, Van Gogh, Matisse, Dufy e Paul Signac (citados na matéria).

\footnotetext{
${ }^{74}$ Jorge Amado, Catálogo do $2^{\circ}$. Salão de Maio, 1938. Apud MONTEIRO, Paulo. Salões de maio. ARS (São Paulo) [online]. 2008, vol.6, n.12 [cited 2018-09-12], 93-103. Online.
} 


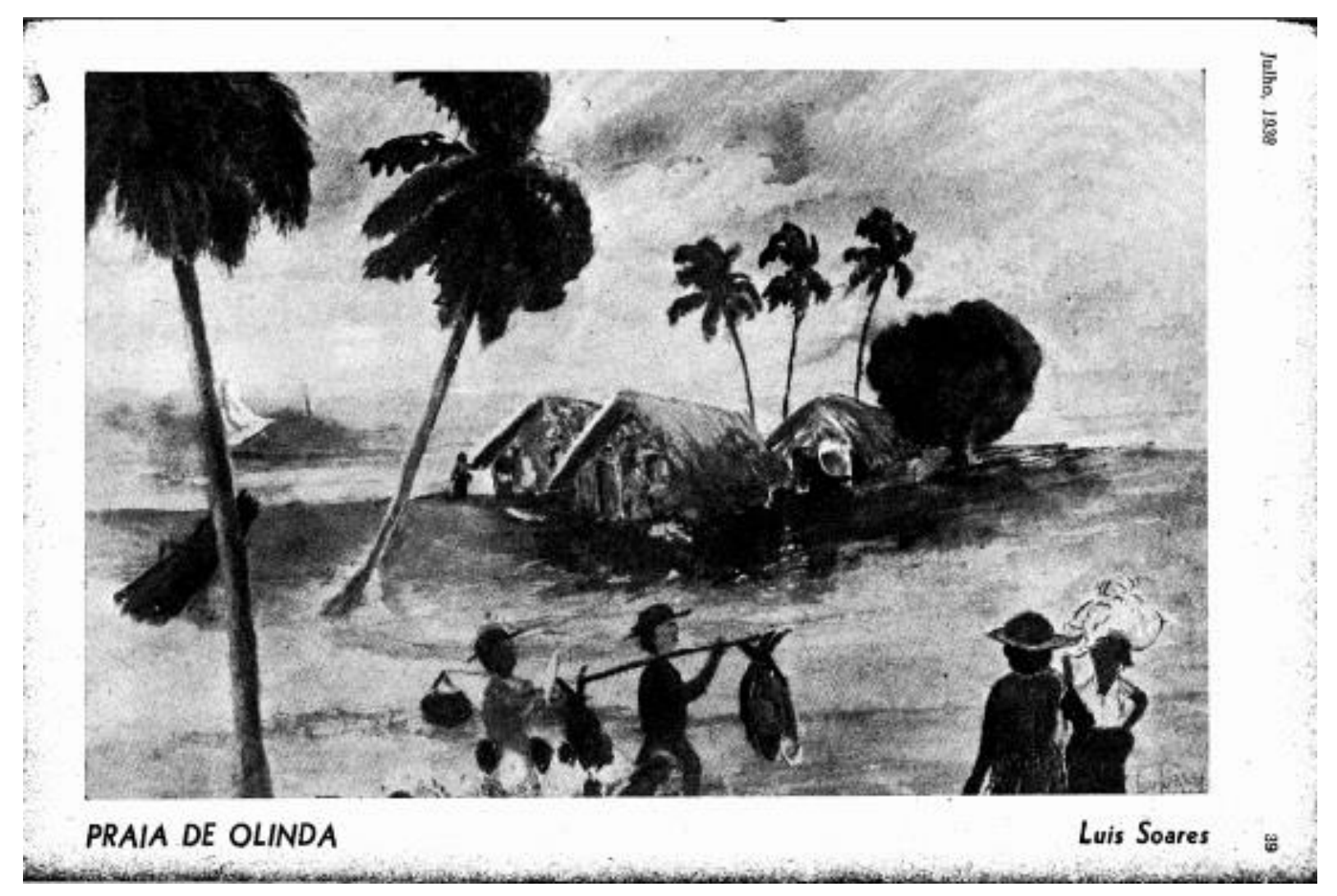

Figura 33 - Luís Soares, Praia de Olinda, s/d. Aquarela. Reproduzida na Esfera 3:39

Na revista número três Silvia trata da exposição do artista pernambucano Luís Soares, realizada pela Casa do Estudante do Brasil. O artista integrou o Grupo dos Independentes do Recife e o movimento regionalista na década de 1920 e, não alcançando reconhecimento local, mudou-se para o Rio de Janeiro, onde ficou conhecido como pintor primitivista (DIMITROV, 2013). Em 1938, data da publicação da reprodução na Esfera da aquarela Praia de Olinda, seu nome estava em projeção no Sudeste do País: havia apresentado no Liceu de Artes e Ofício do Rio de Janeiro e na Galeria Guatapará, em São Paulo a exposição individual Luís Soares - Motivos Pernambucanos e também em São Paulo, no mesmo ano, havia participado da segunda edição do Salão de Maio. A obra de Luís Soares, em evidência, também foi comentada na revista com o título Um grande pintor pernambucano, por Sérgio Soares, jornalista e poeta hoje desconhecido, que no início da década seguinte atuava na revista Vamos Ler. 


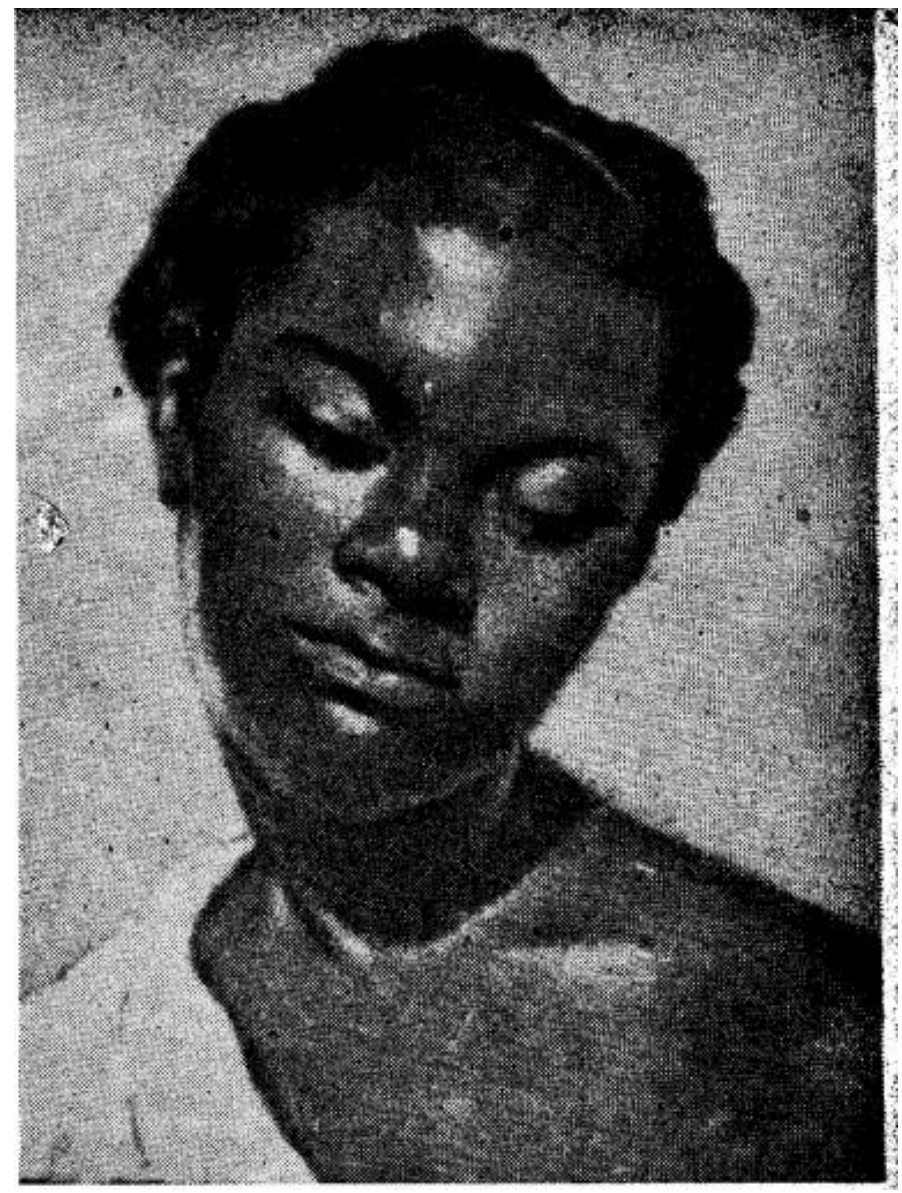

Figura 34-Gilda Moreira, A Negra, c. 1938. Óleo sobre tela. Reproduzido na Esfera 4: 39

Outro artigo de Sylvia, trata da exposição de retratos de Gilda Moreira promovida no ano seguinte, também pela Associação dos Artistas Brasileiros. A artista, membro da elite carioca, era formada em piano pelo INM e em Belas Artes pela ENBA, tendo participado de pelo menos quatro versões das exposições gerais de belas artes, as de 1924, 1926, 1927 e 1928 (na qual concorreu ao prêmio viagem) e de exposições independentes, onde artistas acadêmicos e modernos se reuniam, como o Salão dos Novos realizado em 1926 também no Palace Hotel que, segundo O Jornal, reunia

[...] quadros que assinalam as diversas tendências picturais que impressionam modernamente o meio artístico brasileiro, vendo-se amostras da velha pintura que lembra tricotomias alemãs, e da maneira dos novos e arrebatados temperamentos, que tiram apenas da figura a impressão que ela deixa ${ }^{75}$.

E, por fim, no quarto e último artigo de sua autoria, Silvia trata da exposição de Portinari no Museu Nacional de Belas Artes. O museu havia sido inaugurado no ano anterior pelo Ministério da

\footnotetext{
${ }^{75}$ O Jornal, Rio de Janeiro, 01/08/1926: 3.
} 
Educação e Saúde e era, segundo ela, um espaço expositivo oficial novo na cidade que abria suas portas para a arte moderna. Portinari era um artista consagrado desde a composição $O$ Mestiço, de 1934, "o pintor mais afamado da época" e, inclusive, o autor dos dez painéis retratando os ciclos econômicos da história do Brasil encomendados pelo Ministério para revestir as paredes externas de sua sede, inaugurada dois anos antes, em 1936 (SIMIONI, 2014: 17).

Quando o jornalista paulista Geraldo Ferraz, um dos organizadores do Salão de Maio em São Paulo, publicou na Esfera os artigos Carta sobre artes plásticas no Salão de Maio e Paulista Prado pintor pioneiro, já tinha uma carreira consolidada e se tornado uma personalidade habitual entre os modernistas paulistas. Sua atuação política também é conhecida: entre 1933 e 1934, participou da Frente Única Antifascista e, em 1937, fundou com colegas do Diário da Noite a revista O Homem Livre, com o objetivo de combater esclarecer sobre temas políticos (HOFFMANN, 2007: 131).

Com ilustrações colaboraram o carioca Paulo Werneck, que ilustrou os poemas Formas, de Afonso Schmidt, Poema da hora que passa e A fala soturna do grande desterrado, ambos de Nilo da Silveira Werneck; Jarbas Andrea, caricaturista da revista Dom Casmurro, publicou na Esfera a ilustração Gorki e seus Personagens; Tomás Santa Rosa, que desde que chegou da Paraíba no Rio de Janeiro no começo da década desenvolvia uma carreira de ilustrador de livros e de periódicos ${ }^{76}$, publicou a gravura Trabalho, além de duas ilustrações para os poemas Revelação da Essência e Razão de Ser e de Viver, ambas do português Afonso de Castro Senda, e Oswald de Andrade Filho (Nonê), ilustrou para a Esfera o poema Escutai meu canto de aniquilamento, do conterrâneo Rossine Camargo Guarnieri.

Da pintura de Gilda Moreira retratando uma mulher negra, dos desenhos de de Abel Salazar, retratando tipos populares de Portugal, passando pela paisagem da Praia de Olinda do recifense Luis Soares, pelas associações, movimentos e eventos que reuniam arte e política no Rio de Janeiro, São Paulo e exterior e pelas gravuras de Paulo Werneck, Leopoldo Mendez, Nonê e Santa Rosa, os artigos sobre artes visuais e obras de arte reproduzidos na Esfera representam o congraçamento de artistas provenientes de diferentes países e localidades do Brasil, que independentemente de manifestarem diferentes posições estéticas e políticas, usavam sua arte para denunciar injustiças, defender a democracia e lutar pela paz.

\footnotetext{
${ }^{76}$ Do conterrâneo José Lins do Rego, com quem foi morar logo que chegou à cidade, ilustrou o livro Doidinho, editado pela editora Ariel. Pela mesma editora, ilustrou nos primeiros anos da década de 1930 Cacau e Suor, de Jorge Amado, Urugungo, de Raul Bopp (1934) e Curiango, de Afonso Schmidt (1935) e foi desde esta época o principal ilustrador da editora José Olympio, onde trabalhou até os anos 1950.
} 


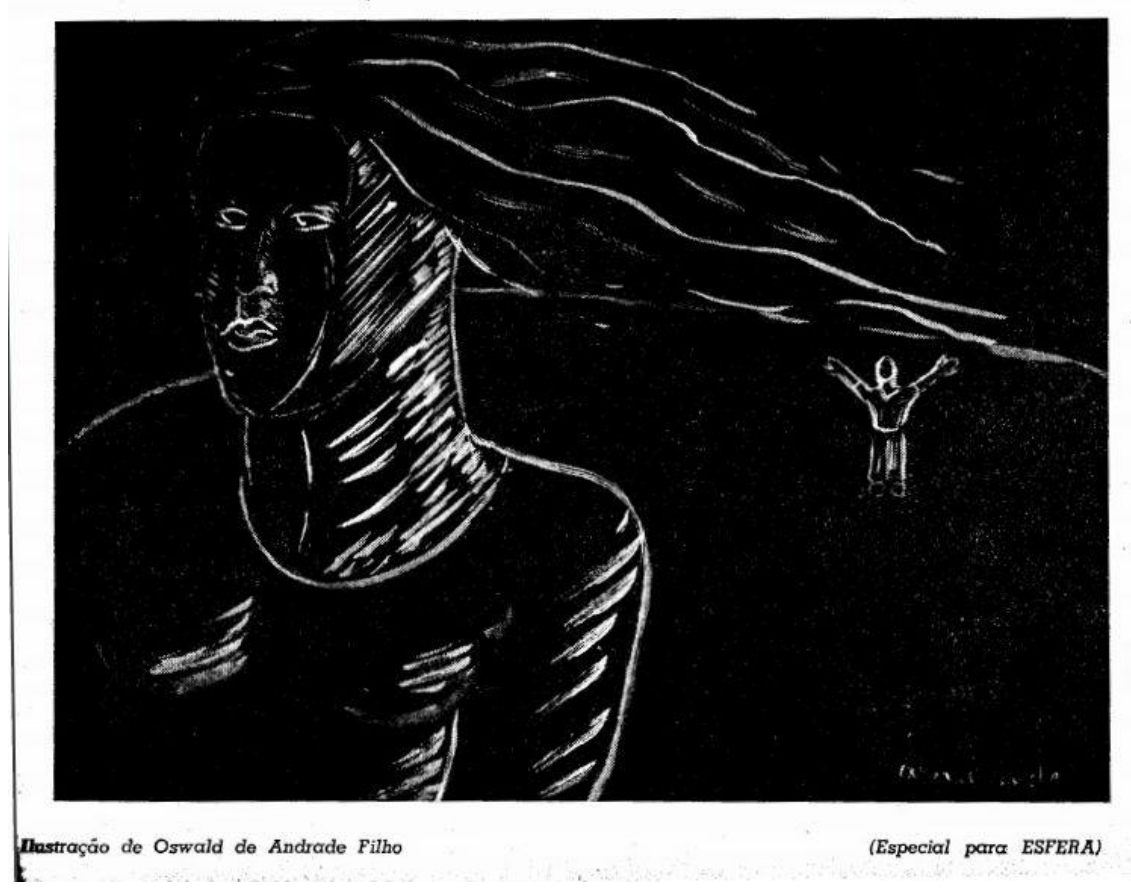

Figura 35 - Oswald de Andrade Filho (Nonê), sem título, c. 1938. Reproduzido na Esfera 3: 7

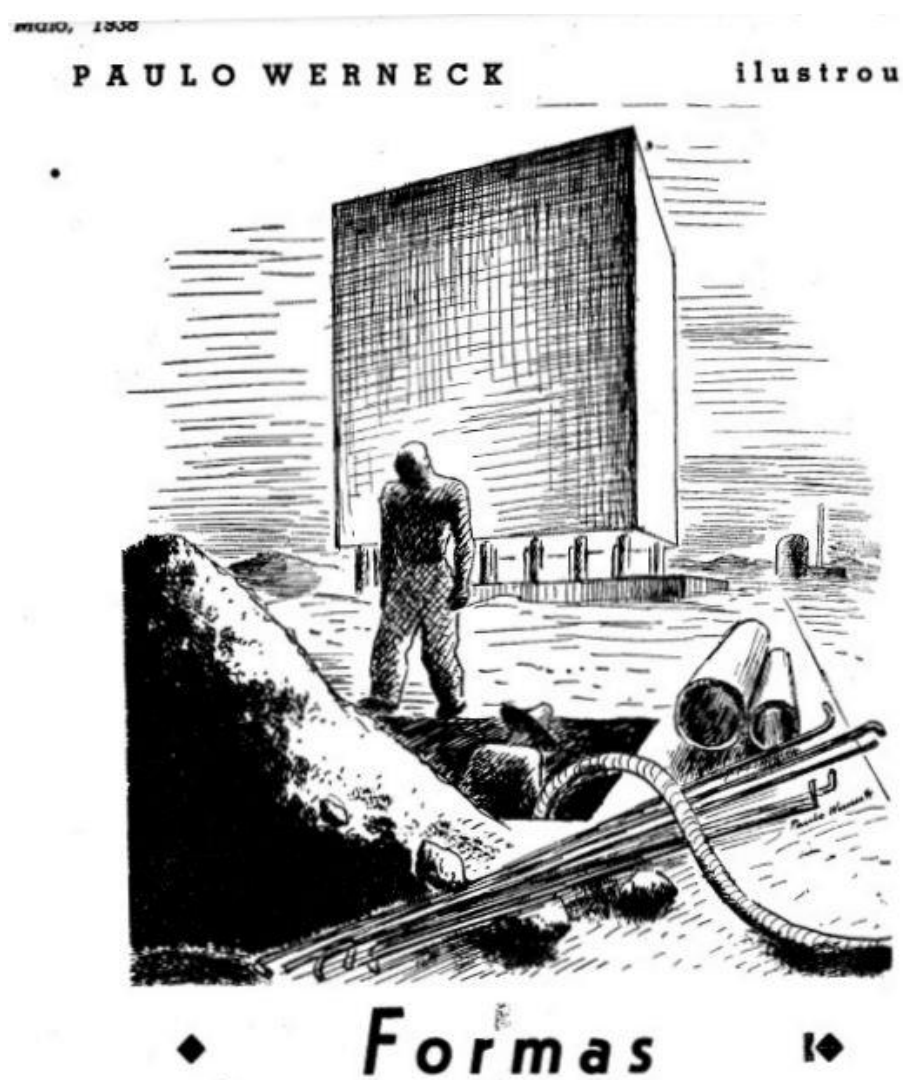

Figura 36 - Paulo Werneck, Formas, c. 1938. Reproduzido na Esfera 1: 21 
O ano do lançamento da Esfera foi de comemoração dos cinquenta anos da abolição da escravidão, o que colaborou para a divulgação de estudos sobre a cultura afro-brasileira. Sobre o tema escreveram o paraibano Ademar Vidal (João Pessoa/PB, 1897 - Rio de Janeiro/ RJ,1986), os baianos Reginaldo Guimarães e Edison Carneiro (Salvador/BA, 1912 - Rio de Janeiro/ RJ 1972) e a recém formada socióloga da Universidade do Distrito Federal, Maria Violeta Coutinho.

O advogado Ademar Victor de Menezes Vidal já tinha uma trajetória de intelectual consolidada: dialogando com Gilberto Freyre, teve participação no Livro do Nordeste (1925) e no Primeiro Congresso Afro-Brasileiro (1934). Realizou extensa pesquisa sobre as manifestações culturais presentes na Paraíba, sendo que seus escritos abordaram usos, costumes e lugares do Estado, enfatizando a cultura popular, o cotidiano do homem do sertão, festas, lendas, danças e brincadeiras. Publicava artigos em periódicos e possui obra literária eclética, que se iniciou com ensaios históricos e biográficos sobre a Paraíba e paraibanos, incursionou em questões econômicas, com Importância do açúcar (1945), literárias, com O outro eu de Augusto dos Anjos (1967) e sociológicas, com Lendas e Superstições (1950), além de inéditos disponíveis na sede do Instituto Histórico e Geográfico Paraibano (VIDAL, 2017). Para a Esfera escreveu o ensaio Regime de maus tratos, sobre os castigos impingidos aos escravos no Brasil. Há uma entrevista com ele no acervo do CPDOC - FGV, realizada no contex to do projeto História política da Paraíba: constituição de acervo (VIDAL, 2017).

Reginaldo Guimarães colaborou com a Esfera com o artigo Negro Fugido. Segundo Sotero, no ano anterior havia organizado com Edison Carneiro e Aydano do Couto Ferraz o II Congresso Afro-brasileiro, em Salvador (SOTERO,2015). Edison, oriundo de uma família negra pertencente à elite baiana, se formou na Faculdade de Direito da Bahia em 1936, mesmo ano que Jorge Amado, escritor já popular no Rio de Janeiro e companheiro durante a juventude na Academia dos Rebeldes, publicou um artigo sobre seu primeiro livro tornando-o conhecido na Capital do País. Com Reginaldo Guimarães, fez parte da célula comunista organizada no início dos anos 30 por Carlos Marighela e militou no Partido por décadas, o que lhes rendeu perseguições e prisões. No fim do ano de 1937 , inclusive, se refugiou da perseguição da polícia política no terreiro de São Gonçalo, de Dona Aninha, ialorixá da Bahia. Pesquisou e escreveu sobre a cultura negra, suas tradições e manifestações religiosas e, segundo Arantes, na década de 1930 seu trabalho foi fundamental para, unir "o mundo dos negros e o mundo dos brancos, o mundo da religião popular e o mundo da cultura acadêmica", (ARANTES, 2016). Orações Milagrosas, onde comenta o trabalho de Aurelino Leal, que foi, segundo ele, "quem primeiro se interessou pela religião das classes mais pobres da Baía"; O que deu 
para dar-se natureza, Martim Pescador, Depoimento Pessoal e Aventura foram suas contribuições para a Esfera.

Aydano do Couto Ferraz participou em 1937 da criação da União de Seitas Afro-Brasileiras, associação vinculada ao PCB e primeira do País que tinha como objetivo proteger e cultivar os valores e as tradições religiosas de matriz africana ${ }^{77}$. No ano seguinte, com Fernando Góes, que integrava a diretoria do Clube Negro de Cultura Social, e Dias da Costa, participou da Comissão das Sociedades Privadas da Raça Negra, criada pelo Departamento de Cultura de São Paulo, chefiado por Mário de Andrade, para promover eventos em comemoração ao cinquentenário da abolição da escravidão.

O alagoano Arthur Ramos, médico psiquiatra, também foi um estudioso da contribuição da cultura afro-brasileira. No ano que escreveu para a Esfera o artigo O folclore cristão do Brasil participou da comemoração do cinquentenário da abolição da escravidão com a publicação do texto O Espírito Associativo do Negro Brasileiro, na Revista do Arquivo Municipal. Seu arquivo pessoal faz parte do acervo da Biblioteca Nacional e está em andamento o projeto da pesquisadora Lígia Fonseca Ferreira, do Instituto de Estudos Brasileiros/USP, que prepara uma edição anotada de sua correspondência com Mário de Andrade ${ }^{78}$.

\section{7 - Outros artigos científicos}

No segundo e terceiro número da Esfera, sem identificação de autoria, constam os seguintes relatos sobre acontecimentos políticos: Guerra? A América do Norte e o Pacto Briand - Kellog, Duração da guerra da Hespanha, A liquidação do caso etíope, Roma - Berlim, A Inglaterra armazena para a guerra; O renascimento da China e Pela cultura do povo. Paulo Zinng, na coluna Movimento internacional, publicou A Checoslovaquia e a Alemanha, a Democracia e o Fascismo e A Alemanha e a luta pelo mercado.

Sobre medicina escreveram a portuguesa Adelaide Estrada, com As maleitas - sezonismo, onde apresenta um estudo sobre a malária e as formas de combatê-la e Fábio Leite Lobo, autor de $A$ Margem da Primeira Semana Regional de Tuberculose e Medicina, fator de civilização. Engajado na luta pela democracia, durante o ano de 1937 Fábio também foi colaborador da Dom Casmurro. Neste período atuou como tradutor tendo, entre outras obras, traduzido A vida de Pasteur, de Renne Valery

\footnotetext{
${ }^{77}$ SAUDAÇÃO ao Povo Negro. Partido Comunista Brasileiro, 2009 . Disponível em: <https://pcb.org.br/portal2/14/saudacao-ao-povo-negro/>. Acesso em: 10 out. 2018.

${ }^{78}$ Esta correspondência é formada por 46 cartas localizadas na Biblioteca Nacional e no arquivo pessoal de Mário de Andrade, pertencente ao acervo do IEB.
} 
Radot (editora Vecchi, 1939) e Romain Rolland: sua vida, sua obra, de Stefan Zweig (edições Pongetti, 1937).

Edgard Cavalheiro tinha 27 anos, era estudante de Direito em São Paulo quando escreveu especialmente para a Esfera o artigo Madame Curie ${ }^{79}$, sobre a cientista polonesa Marie Curie, primeira mulher que recebeu o Prêmio Nobel (Química,1911). Só dois anos depois publicou a biografia do poeta Fagundes Varella (1841 - 1875), trabalho que lhe deu projeção nacional e lhe abriu as portas do meio jornalístico, onde foi ativo nas décadas seguintes (D’ONOFRIO, 2012).

\section{8 - Intercâmbio internacional}

A Esfera publicou obras de autores estrangeiros, tanto com textos especialmente escritos para a revista, quanto através da transcrição de artigos opinativos e ficcionais, e da reprodução de pinturas e gravuras publicados em outros periódicos e livros, representando a rede internacional de intelectuais formada em torno do combate ao fascismo e da Internacional Comunista.

A principal relação internacional era com Portugal, já que foi criada para ser uma revista de intercâmbio luso-brasileiro. A forte amizade entre Afonso de Castro Senda e Silvia, comprovada por bilhetes, dedicatórias e recortes de jornal existentes no arquivo, foi certamente um dos motivos que originou e facilitou este intercâmbio. Afonso de Castro Senda era um dos pseudônimos de Afonso de Castro Moreira, militante do movimento neorrealista português e membro na juventude do grupo Jovens Liras, associação de estudantes neorrealistas que colaboravam com a revista Pensamento, de Porto e autores do livro $O$ nosso eu (1936), único livro de poemas publicado que fazia parte da coleção literária projetada pelos organizadores desta revista (DIAS, 2011). Viveu no Rio de Janeiro por um período (não foi possível precisar o tempo exato), no final dos anos 1930.

Segundo Moreira, o neorrealismo português foi um duplo movimento, artístico e político, que tinha por objetivo promover, "ao mesmo tempo e por meio da ideololgia marxista, um ato de resistência e luta contra a alienação provocada pelo regime do Estado Novo" instalado em Portugal em 1933. Formado por um grupo de jovens "em sintonia com os problemas sociais, políticos e econômicos em Portugal", veio acompanhado de uma intensa atividade teórica e se disseminou através da imprensa cultural, tendo como principais veículos os periódicos O Diabo, Vértice e Sol Nascente, que mantiveram, através de Afonso de Castro Senda, forte intercâmbio com a Esfera (MOREIRA, 2010).

\footnotetext{
${ }^{79}$ Esfera, Rio de Janeiro, novembro/1938, n.7:18 - 20.
} 
A este vínculo político se aliava o crescente interesse dos intelectuais portugueses pelos novo romance social brasileiro que, desde o início da década, passou a ser divulgado e discutido em periódicos neorrealistas. Segundo Salla, em seu estudo sobre Graciliano Ramos em Portugal, em 1934 o escritor Ferreira de Castro $^{80}$ publicou no periódico $O$ Diabo o artigo Literatura Social Brasileira ${ }^{81}$ onde, provavelmente pela primeira vez, os nomes de Rachel de Queiroz, José Lins do Rego e Jorge Amado apareceram em Portugal. A partir desta publicação o romance social brasileiro ganhou notoriedade no país, com a divulgação de capítulos e de críticas em periódicos ligados ao movimento neorrealista. No mundo literário português "[...] o final dos anos 1930 se afigura como momento da recepção efetiva e maciça por parte da imprensa cultural lusa (revistas e suplementos literários) do novo romance brasileiro" (SALLA, 2016: 13).

Matérias de autores portugueses publicadas nas revistas O Diabo, Sol Nascente, Vértice, Seara Nova e outros periódicos neorrealistas eram transcritas na Esfera e vice-versa. Afonso escreveu nos oito números da revista a coluna Documentário Cultural Português (que apenas na edição número um se chamou Panorama Cultural Português). No primeiro ele apresenta a seção e expõe seu objetivo:

Neste documentário procuraremos fixar com a oportunidade devida e a independência máxima, tudo quanto de interessante vá aparecendo, melhor: vá tomando forma própria no nosso meio de província europeia. ${ }^{82}$

No quarto número da revista, ele ressalta o interesse pelo aprofundamento da relação com o Brasil: "Esfera sabe que vai suprimir o Atlântico. Sabe que vai pôr Portugal no Brasil e o Brasil em Portugal. Portugal e Brasil já se queriam bem, mas vão-se querer muito mais" $"$.

Nos periódicos portugueses $O$ Diabo e Sol Nascente Afonso assinava uma seção similar, Panorama Cultural Brasileiro, onde publicava notas e artigos sobre a produção de autores brasileiros como Jorge Amado, José Lins do Rego, Rachel de Queiroz, Graciliano Ramos, Armando Fontes e Érico Veríssimo, o que o tornou um grande divulgador da literatura brasileira contemporânea no País. (ALVES, 2006: 51, 67).

Além dele, outros vinte e quatro autores portugueses colaboraram nestas oito edições da Esfera, sendo a maioria formada por jovens redatores do Diabo e $O$ Sol Nascente, vinculados à

\footnotetext{
${ }^{80}$ Ferreira de Castro (1898-1974) foi um escritor português que viveu em Belém do Pará no período áureo da produção seringueira e que na década de 1920 se notabilizou por seus livros sobre a Amazônia.

${ }^{81}$ Castro, Ferreira de. Literatura Social Brasileira, O Diabo, 2/09/1934.

${ }^{82}$ Esfera, Rio de Janeiro, maio/1938, n.1: 66.

${ }^{83}$ Esfera, Rio de Janeiro, agosto/1938, n. 4: 64.
} 
corrente literária neorrealista e ao movimento antisalazarista. Com exceção de Manuel Anselmo (1911-1992), Manuel da Fonseca (1911-1993), Mário Dionísio (1916-1993), Irene Lisboa (18921958), Tomas Kim (1915-1967) e Abel Salazar (1889-1946), cujas obras vêm sendo revisitadas em Portugal, e dos consagrados Adolfo Casais Monteiro (1908-1972), José Régio (1901-1969) e João de Barros (1881-1960), os outros quinze colaboradores têm suas obras praticamente esquecidas. Assim como aconteceu com os autores brasileiros, a juventude de alguns e a forte repressão e censura do estado novo português (que fazia com que muitos escrevessem sob pseudônimos) podem explicar tanto a efemeridade de sua atuação no meio literário quanto o seu esquecimento.

A contribuição de Abel Salazar, um dos líderes do movimento neorrealista, o mais velho entre os portugueses que colaboraram com a revista (na época professor universitário afastado da universidade por opor-se ao governo de Salazar) destaca-se tanto pela sua participação nas oito primeiras edições (colaborou nos oito primeiros números da Esfera publicados em 1938 e 1939, com seis ilustrações e os artigos As várias Facetas da Verdade, A revolução científica e filosofia do século XX, Millet e Graciliano Ramos e Masdekismo e Osirismo) quanto pela afinidade que Silvia deixou entrever ao conservar em seu acervo uma pasta contendo recortes de jornal com entrevistas, críticas e comentários sobre sua obra publicados na imprensa portuguesa quando ele faleceu e outra com dezenas de desenhos de sua autoria enviados de Portugal especialmente para ela.

A literatura de outros países da América do Sul está presente desde o primeiro número, com a seção Sobre Literatura Hispano-Americana onde foi publicado Los historiadores de la literatura en el Brasil, do jornalista e militante argentino antiperonista Atílio Garcia Mellid. Nos outros números a seção foi substituída pela coluna Letras Hispano-Americana, de Enrique Rodríguez Fabregat (San José/Uruguai, 1895 - 1976), que teve destacada atuação na imprensa cultural de seu país. Político e militante de esquerda, exilou-se no Brasil durante o período da ditadura de Gabriel Terra (1933 - 1938). Colaborou com a revista Dom Casmurro em 1939 e publicou na sua coluna na Esfera os seguintes artigos: Índice de la poesia Peruana contemporânea, Tala: el nuevo libro de Gabriela Mistral, El cinquentenario de Sarmiento, sobre o escritor argentino Domingos Faustino Sarmiento (1811-1888), Nuevos Libros Americanos e La voz que no apago la muerte, sobre a poetisa argentina falecida no mês anterior, Alfonsina Storni.

Em 1944, Henry A. Holmes escreveu sobre este período de sua vida:

Enrique Rodriguez Fabregat es uruguayo y goza de gran consideración en los circulos intelectuales de Montevideo. Ha sido periodista, abogado, conferenciante y Ministro de Instrucción Plublica en la República Oriental. Por causas que no serian dificiles de imaginar, 
tuvo que marcharse al Brasil, desterrado, acogindose al calor de esa fabulosa tierra y al cariñio de almas privilegiadas que le prestaron ayuda para la realización del empeño de engendrar el hombre que no quiso ser rey. Se terminó en Rio de Janeiro, en 1939. A su permanencia en el Brasil se debe también un libro sobre el Amazonas que le valió un premio, muchos elogios y la suerte de verlo traducido al inglês. (HOLMES, 1944: 370)

Alfonso Hernandez Catá publicou na Esfera La Moneda Ideal, uma crítica à biografia de Rodolfo Valentino de H. L. Mencken. Nasceu na Espanha, mas foi criado em Cuba, onde fez sua vida profissional: foi jornalista e escritor, atividades que nunca parou de exercer, mesmo após ingressar na carreira diplomática. Quando colaborou com a Esfera exercia a atividade no Rio de Janeiro, onde se relacionava no mundo intelectual, colaborando com artigos e textos ficcionais em periódicos, entre eles as revistas de esquerda Diretrizes e Dom Casmurro, promovendo a divulgação da cultura cubana. Viveu no Rio de 1938 até sua morte, em 1940, em decorrência de um desastre aéreo (BUENO, 1990).

A Esfera também veiculou obras ficcionais de autores da América Latina: poemas de Alvaro Yunque (argentino), Enrique Fabregat, Miguel Bustos Cerecedo (mexicano), Nicolas Guillen (cubano), Gabriela Mistral (chilena) e Serafin J. Garcia (uruguaio) e um conto do boliviano Jesus Lara.

Os Estados Unidos estão representados pela crítica intitulada Aventura, onde Edison Carneiro comenta Tacão de Ferro, uma das mais conhecidas obras do romancista e ativista socialista, Jack London, (cuja primeira tradução para o português foi feita por Silvia e publicada pela editora Estrela Vermelha, em 1947, com capa e ilustrações de Paulo Werneck) e no artigo O Poeta, de Phócion Serpa, sobre Ralph Waldo Emerson (1803 - 1882).

Provenientes ou referindo-se ao mundo intelectual europeu, além dos portugueses foram publicados os seguintes artigos: O homem Perfeito e Feliz do carioca Thomaz Murat, que trata da vida e obra de Goethe; Hristo Botjov, um elogio à vida e obra do poeta e revolucionário búlgaro, ressaltando o compromisso de sua arte com a justiça social, e Palavras sobre a missão utilitária do artista, ambos de Kliment Kostov, da Bulgária. Odilon Negrão escreveu sobre o livro Viagem ao Brasil, do suíço Luiz Agassiz e sua esposa americana, Elizabeth Cary Agassiz e Frederico Reys Coutinho comentou o livro do francês André Malraux, publicado em 1930 na França, em Notas sobre A Estrada Real.

As obras ficcionais europeias publicadas na Esfera são a tradução do artigo do francês Jacques Madaule, Poesia e realidade, o conto Feuille D'Album de Katherine Mansfield, traduzido por Jorge 
Amado e De Charles Louis Phillipe, trechos de autoria do escritor francês transcritos da revista Caractères.

Por fim, alguns intelectuais estrangeiros foram estudados e comentados em artigos científicos: Afonso de Castro Senda escreveu sobre os franceses Jean Guéheno e Seignobos e sobre o filósofo dinamarquês Harald Høffding e Edison Carneiro, como sabemos, sobre o livro Madame Curie, escrito por sua filha Eva Curie e traduzido naquele ano por Monteiro Lobato.

Em Artes os portugueses colaboraram com dois artigos teóricos, Esquema para um ensaio sobre a arte como criação livre e inalienável, de Adolfo Casais Monteiro e Acerca dos conhecimentos indispensáveis ao escritor de Belas Artes, de João Alberto, e três críticos: Recordações do Minho Arcaico de Abel Salazar, de Carlos Relvas, Dominguez Alvarez, de João Alberto e Abel Salazar em Lisboa, de Jorge Domingues.

. de Abel Salazar

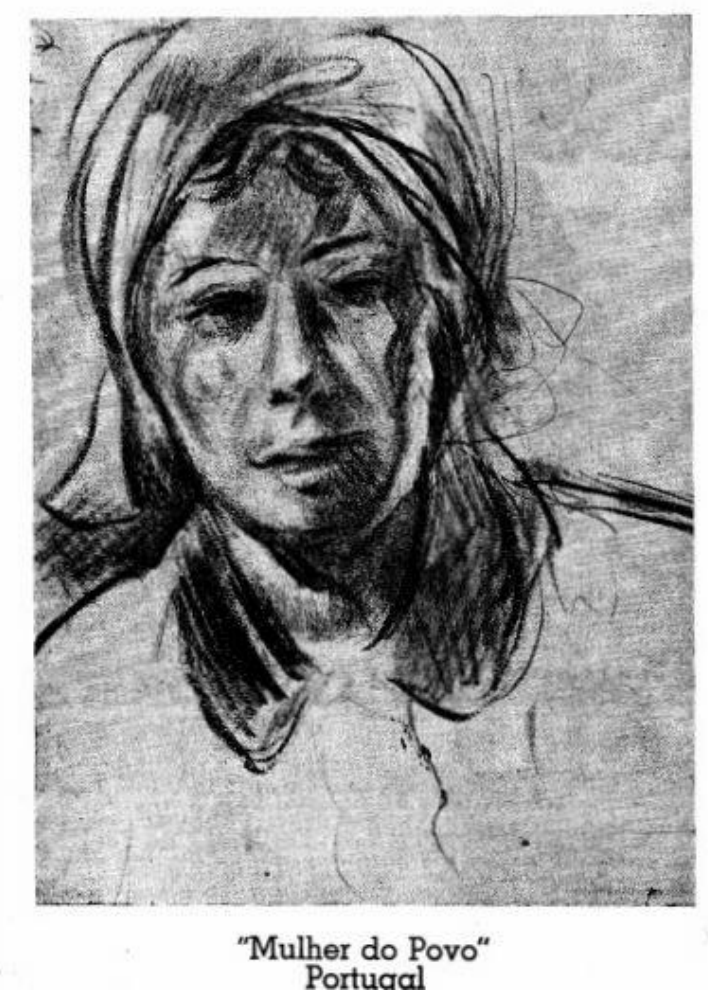

Figura 37 - Abel Salazar, Mulher do Povo, sd. Desenho. Reproduzido na Esfera 1:25

O artigo Esquema para um ensaio sobre a arte como criação livre e inalienável defende "que as produções artísticas deveriam brotar de necessidades profundas dos homens, e não das demandas em torno desta ou daquela causa" opondo-se, portanto, à arte social no Brasil e ao neorrealismo português. Este era o debate que a nova geração de escritores portugueses que preconizava uma literatura engajada com os problemas sociais travava com os intelectuais da geração anterior, como 
os modernistas portugueses Casais Monteiro e José Régio “que privilegiavam dramas subjetivos $e$ espirituais, e foram rotulados como defensores da "arte pela arte" (SALLA, 2016:101).

O mais comentado artista plástico foi Abel Salazar, um intelectual de muitas facetas: em 1915 participou com obras de pintura e desenho na Exposição dos Humoristas e Modernistas realizada no Porto e doutorou-se na faculdade de Medicina da mesma cidade, onde iniciou sua carreira no magistério superior. Em 1936, foi expulso com outros professores universitários do funcionalismo público, pela sua atuação contra o salazarismo e, impedido de frequentar a faculdade e de viajar, passou a se dedicar intensamente à publicação e divulgação de textos sobre temáticas sociais, políticas, filosóficas e literárias e à prática artística, produzindo pinturas e gravuras. Colaborou com seis ilustrações nos oito primeiros números da Esfera. Silvia tinha admiração por ele e provavelmente o conheceu pessoalmente, pois, como sabemos, conservou em seu acervo pastas contendo recortes de jornais sobre seu falecimento e dezenas de desenhos de sua autoria. Seu arquivo pessoal pertence a Fundação Mário Soares e está disponibilizado no site dessa instituição ${ }^{84}$.

Leopoldo Mendez é hoje um prestigiado artista modernista mexicano e já era conhecido quando uma xilogravura de sua autoria foi reproduzida na Esfera. A imagem, exposta no Salão de Maio de 1938, ilustra o artigo de Jorge Amado Retrato do Pintor Leopoldo Mendez. Este artista tem um papel central na história da arte e política mexicana: integrou o Partido Comunista, de 1930 a 1945, a Liga dos Escritores e Artistas Revolucionários (LEAR) e, em 1937 criou a Oficina Gráfica Popular (TGP), um coletivo de artistas que se tornou um centro de artes internacional nas décadas de 1940 e 1950. Estava no auge de sua produção artística e atuação política quando seu trabalho foi publicado na Esfera.

Segundo o artigo de Jorge Amado na Esfera,

Leopoldo Mendez, jovem como é, tem na pintura de seu país (e lembrem-se que se trata da pintura do México talvez hoje a mais importante do mundo) um lugar já definitivo, porém tem muito mais que isso: tem um futuro que talvez leve seu nome ainda mais longe que o daquele gigante sorridente que é Diego Rivera. ${ }^{85}$

${ }^{84} \mathrm{http}: / / \mathrm{www} . \mathrm{fmsoares.pt/}$

${ }^{85}$ Esfera, n. 2:21. 


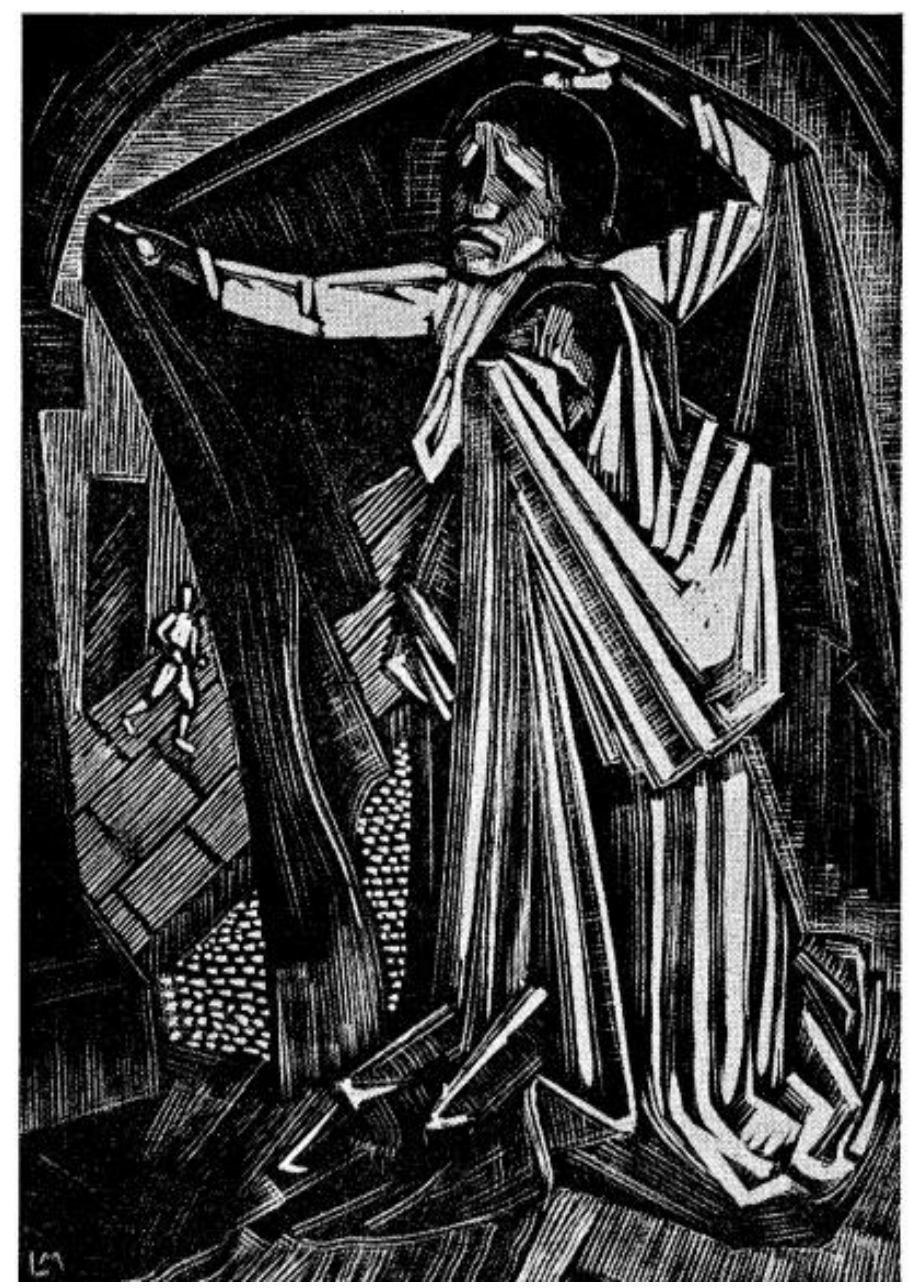

Figura 38 - Leopoldo Mendez, sem título, c. 1938. Xilogravura. Reproduzida na Esfera, n. 2: 22

Uma reprodução da pintura Natureza Morta de Emil Filla (Chropyně/ Império AustroHúngaro), 1882 - Praga/ Checoslováquia,1953) estão nas páginas da revista ilustrando a entrevista concedida a Flávio de Carvalho, publicada com o título Retrato, tendo ao lado uma foto do artista brincando com seu cão. No início do século XX, Emil, ex-aluno da Escola de Belas Artes de Praga, viajou pela Europa entrando em contato com o que acontecia nas artes modernas na vanguarda do mundo das artes internacional. Amigo de Picasso e outros artistas contemporâneos, adotou por muito tempo o cubismo como base de suas pinturas. Na década de 1930, vivendo em Praga e envolvido com a luta antifascista na Europa, participou de quase todas as exposições nacionais, apresentando trabalhos em sua maioria com temas sociais. Em 1939, foi detido ao falar em uma assembleia antifascista e ficou preso nos campos de concentração de Dachau e Buchenwald até $1945^{86}$.

\footnotetext{
${ }^{86}$ MLÁDKOVÁ, J. Emil Filla - tschechischer und europäischer maler. Czech Radio, 2007. Disponível em: <https://www.radio.cz/de/rubrik/kultur/emil-filla-tschechischer-und-europaeischer-maler>. Acesso em: 28 fevereiro 2019.
} 


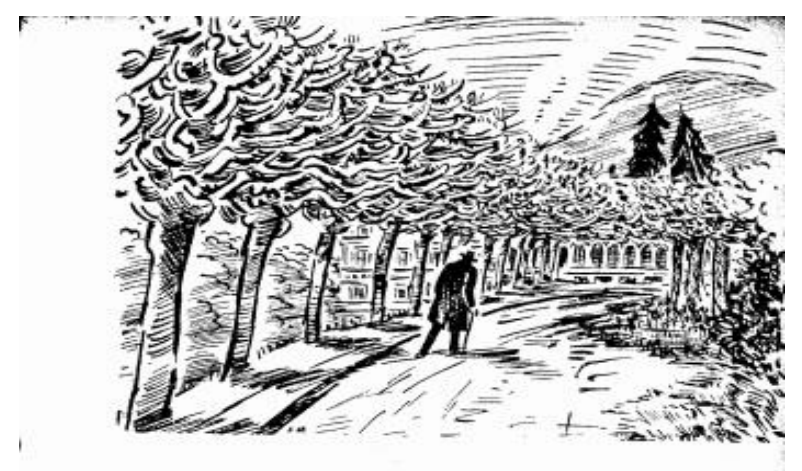

Figura 39 - Frans Masereel. Sem título, c. 1938. Desenhos. Reproduzidos na

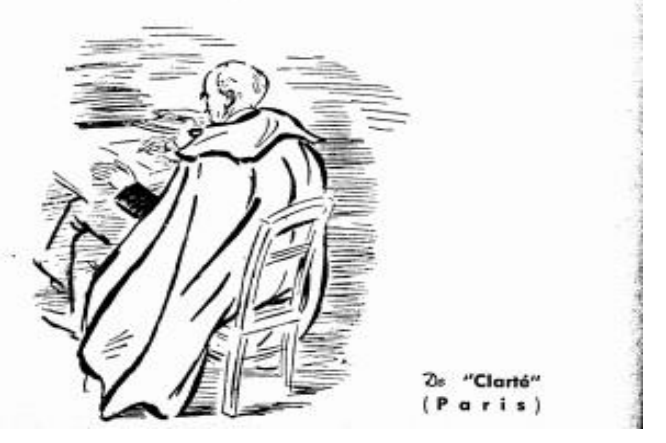

Silvia escreveu para Frans Masereel, em 1938, apresentando a Esfera e pedindo a sua colaboração na revista. A resposta veio em uma carta manuscrita onde o artista se dirige a ela como chére camarade, termo reconhecidamente utilizado entre comunistas. Nesta carta ele aceita o convite e pede mais informações.

Frans Masereel (1889-1972) foi um artista gráfico belga que trabalhou principalmente na França. Documentarista, cronista, militante do partido comunista e pacifista. Participou da primeira fase da Esfera apenas uma vez, ocupando duas páginas com quatro desenhos que retratam o escritor e pacifista Romain Rolland. Só em 1946 voltou a colaborar em outros quatro números da revista com gravuras e desenhos, alguns feitos especialmente para ela. O livro, Remember ${ }^{87}$, com vinte xilogravuras de sua autoria, publicado neste ano, também faz parte do acervo de Silvia e, frente às dificuldades e o alto custo da importação de livros de arte no período, é provável que o exemplar de Silvia, número 50 de uma tiragem limitada em 950, tenha sido enviado pelo autor. Os vínculos entre eles não param por aí: Silvia teve grande interesse pelo escritor francês Charles Louis Phillipe. Este autor, falecido em 1909, escreveu novelas que descreviam sua experiência pessoal com o sofrimento e a pobreza, mostrando o lado pobre de Paris e Bourbonnais, região onde nasceu. Sua obra mais

\footnotetext{
${ }^{87}$ MASEREEL, Frans. Remember, Editora Herbert Lage; Berne; 1946.
} 
consagrada foi Bubu de Montparnasse (1901), que conta a história dos relacionamentos de uma jovem prostituta, mas também é autor de novelas que tratam da pobreza na zona rural da França: La Mère et l'enfant (1900), Le Père perdrix (1902) e a inacabada Charles Blanchard (1913) ${ }^{88}$. Frans Masereel foi um dos ilustradores da primeira edição em alemão de Bubu de Montparnasse ${ }^{89}$. A obra de Charles circulou na época no Rio de Janeiro e Silvia se interessou tanto por ela, que Carlos Drummond de Andrade o mencionou em um dos poemas que dedicou a ela: "Ruas, cidades de Silvia / sob a pura claridade, em todas as casas vive a graça da fraternidade. / Graça em que de coração ela quer que eu participe / pois me sabe seu irmão em Charles Louis Phillipe". A Esfera publicou dois artigos de sua autoria: Correspondência e De Charles Louis Phillipe, trechos transcritos em francês da Revue Caractéres.

Além de livros, a partir da década de 1920 Masereel publicou seus trabalhos em diferentes revistas e jornais da França, Suíça e Bélgica, abordando temas que giravam em torno das questões sociais e da guerra. Mon livre d'heures (1919), novela narrada através de 167 xilogravuras, sua obra mais conhecida, representa a experiência da vida humana na cidade moderna do início do século XX. Frans Masereel, ainda pouco conhecido no Brasil, é um dos expoentes da arte social na Europa de seu tempo. Sua obra plástica é atualmente, principalmente na Europa, objeto de estudo e exposições e seus livros de reedições ${ }^{90}$.

Provenientes de diferentes países e continentes estes artistas e intelectuais formavam uma rede mundial cujos vínculos iam além da filiação aos partidos comunistas de seus países. O que os unia era a luta pela paz, contra o fascismo e as injustiças sociais. Um exame mais aprofundado nas biografias dos colaboradores da Esfera revelou a diversidade de experiências estéticas, políticas e sociais de brasileiros e estrangeiros que integraram esta rede.

\footnotetext{
${ }^{88}$ Wikipédia. Disponível em: <https://en.wikipedia.org/wiki/Charles-Louis_Philippe>. Acesso em: 13/09/2018.

${ }^{89}$ Masereel, Frans; Charles-Louis Philippe. Bubu de Montparnasse; Hardcover; München;1920.

${ }^{90}$ BIOGRAFIE. Frans Masereel Stiftung. Disponivel em: 〈http://masereel.org/biographie/>. Acesso em: 10 setembro 2018. FRANS Masereel und seine Arbeiten für die Presse. Museum für Druckkunst Leipzig, 2016. Disponivel em: <https://www.druckkunst-museum.de/de/termin/frans-masereel-und-seine-arbeiten-fuer-die-presse.html>. Acesso em: 8 set. 2018. ZWEIG, Stefan. Frans Masereel, homem e escultor, editora Axel Juncker, Berlim, 1923.
} 


\section{9 - Colaboradores}

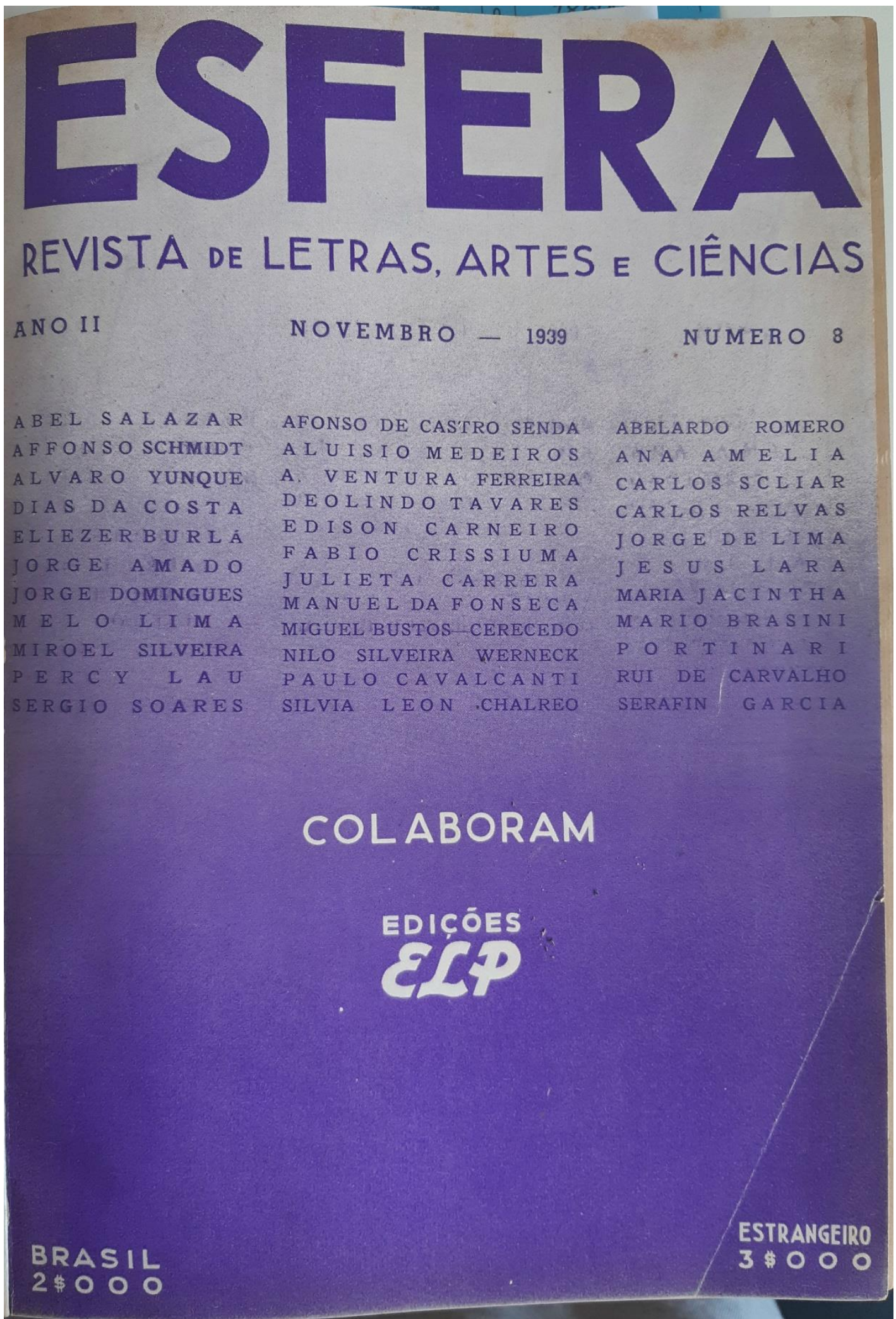

Figura 40 - Capa da Esfera n. 8, novembro, 1939 
Na capa da primeira edição de maio de 1938 constam os nomes de Abel Salazar, Afonso de Castro Senda, Afonso Schimdt, Benjamim Lima, Atilio Garcia Mellid, Carlos Cruz, Cleomenes Campos, Dias da Costa, Eneida, Erico Veríssimo, Fábio Leite Lobo, Fábio Crisciúma, Gerardo Reys, Frederico Reys Coutinho, Graciliano Ramos, Heitor Lucio, Henriqueta Lisboa, Jorge Amado, Jeannete Dudin, Joel Silveira, José Régio, Maria Violeta Coutinho, Marques Rebelo, Maria Jacintha, Natalina Bastos, Oswaldo Orico, Phocion Serpa, Paulo Werneck, Roberto Alvim Correa, Rubem Braga, Santa Rosa, Theoderik de Almeida e Sylvia.

$\mathrm{Na}$ contracapa, sob o título Colaboradores, além dos nomes acima citados, aparecem os de Abelardo Romero e Waldemar de Oliveira e os colaboradores do exterior são citados novamente.

A primeira página também apresenta o nome dos redatores em ordem alfabética: Afonso de Castro Senda, Dias da Costa, Eneida, Fábio Leite Lobo, Fábio Crisciúma, Graciliano Ramos, José Lins do Rego, Jorge Amado, Roberto Alvim Corrêa e Santa Rosa.

No número dois, novos redatores, que gozavam de prestígio na época, se uniram aos anteriores, denotando o crescimento e o fortalecimento da publicação. Álvaro Moreyra, Carlos Drummond de Andrade, José Lins do Rego, Manuel Bandeira e Oswald de Andrade estão entre eles. Esta equipe permaneceu com poucas alterações até o número sete. Em todos os 24 números Silvia colaborou com críticas e artigos literários e de artes plásticas, além de dois artigos ficcionais.

Nos oito números estudados foram publicados 279 obras de 176 autores $^{91}$, sendo que entre os colaboradores cuja naturalidade identifiquei (não foram encontrados dados de treze), 115 eram brasileiros e 48 estrangeiros ${ }^{92}$. Entre os primeiros, apenas 28 eram cariocas, os outros 87 , mais do que o triplo, nasceram em outras localidades do País e, entre os 153 cujos locais de moradia em 1938 foram identificados, 64 moravam na cidade sede da revista, 48 viviam em outros estados do Brasi1 ${ }^{93}$, 11 em países da América Latina, 24 em Portugal e quatro em outros países da Europa.

Esta diversidade de origens também está representada pelos residentes no Rio de Janeiro: havia apenas 24 cariocas, 31 eram oriundos de outros estados do Brasil e seis nascidos no exterior. A grande maioria havia se mudado para o Rio de Janeiro por perseguição política, sendo que mais de uma dezena foi presa por participar de ações, expressar opiniões de esquerda ou por ter sido acusado

\footnotetext{
${ }^{91}$ Estes números se referem a crônicas, críticas de arte e literárias, contos, capítulos de livros e conteúdos imagéticos. As seções Jornais e Revistas, Livros, Cinema e Rádio não fazem parte deste total. Entre as matérias estudadas, 39 não estão assinadas e seis são assinadas com iniciais. Duzentas e duas são assinadas por homens.

92 Portugal (25), Argentina (4), Cuba (3), Bélgica (2), França (2), México (2), Uruguai (2), Bolívia (1), Chile (1), Peru (1), Bulgária (1), Espanha (1), República Tcheca (1), Ucrânia (1), Suíça (1).

93 Aracaju/SE (1), Salvador/BA (6), Belém/PA (2), Belo Horizonte/MG (1), Porto Alegre/RS (6), Recife/PE (6), Fortaleza/CE (2), Florianópolis/SC (1), RN (1), São Paulo (22).
} 
de participação na insurreição de 1935. Além dos perseguidos políticos, havia os que imigraram para frequentar o ensino superior na Capital da República e os que buscavam o prestígio que só poderiam conquistar nestas cidades centrais através de contatos com artistas e intelectuais, da divulgação de suas obras na imprensa e de críticas, prêmios, mostras de arte e publicações de livros decorrentes desta exposição.

Entre os estrangeiros, Afonso de Castro Senda, o hispano-cubano Alfonso Hernandez Catá, que exercia funções diplomáticas e o uruguaio Enrique Fabregat, exilado por questões políticas, residiram temporariamente no País. Afonso de Castro Senda e Enrique Fabregat, como vimos, além de colaborarem com artigos literários e jornalísticos, eram os responsáveis pelas colunas Documentário Cultural Português e Letras Hispano Americana. O peruano Percy Lau e a ucraniana Elisa Lispector haviam se mudado para o Brasil ainda jovens e se radicado no País e Mário Antônio Barata, nasceu na Suíça, mas era filho de brasileiros e vivia entre o Brasil e a Europa.

A maioria dos colaboradores era oriunda de famílias de classe média e alta, mas alguns jornalistas e escritores, principalmente os imigrantes, passavam dificuldades financeiras, tendo que morar em pensões, disputar matérias e aceitar empregos em outras áreas. Cerca da metade dos artigos foi escrita por jovens de 16 a 30 anos, entre eles estudantes universitários ligados ao PCB e ANL que publicaram artigos opinativos e ficcionais e escritores e artistas que se iniciavam no mundo intelectual. Mas convivem na revista autores de três gerações, que tinham entre 66 e 15 anos de idade.

$\mathrm{Na}$ contribuição dos cariocas fica nítida a importância das relações pessoais na edição dos artigos para a Esfera. Maria Jacintha e Sylvia contatavam pessoas de seu meio para colaborar com a revista, como profissionais do teatro (pois desde a época do Athénée Sylvia se relacionava neste mundo (em 1938 já era filiada à Associação Brasileira de Críticos Teatrais), integrantes do PCB, do movimento estudantil e de outras organizações políticas feministas e antifascistas. Mais do que mostrar obras de autores prestigiados e premiados, havia interesse na divulgação de novos autores, principalmente pela publicação de trabalhos, a maioria poemas, de jovens escritores alinhados à política cultural do PCB.

Mas a diversidade de autores ligados à editoria da revista por vínculos políticos e pessoais, mais do que estéticos, traz para suas páginas um conteúdo também diverso, que representa tanto outras correntes de literatura social e modernista menos conhecidas, quanto os sentimentos, anseios, ideias e ideais de autores que não alcançaram prestígio nem reconhecimento no mundo literário de seu tempo, mas que encontraram na revista espaço para se expressar. 
A maior parte dos escritores brasileiros eram de origem nordestina. Nascidos em Recife, Manuel Bandeira (1886 - 1968), Mario Sette (1887 - 1950), Lucilo Varejão (1892 - 1965), Osório Borba (1900 - 1960), Álvaro Lins (1912 - 1970), Paulo Cavalcanti (1915 - 1985), Deolindo Tavares (1918 - 1942) e Mário Souto Maior (1920 - 2001).

Manuel Bandeira, educado no Colégio Dom Pedro II do Rio de Janeiro, se fez presente na Semana de Arte Moderna de 1922 em São Paulo com o poema Os Sapos, declamada por Ronald de Carvalho na abertura do evento. Quando publicou na Esfera já era um escritor conhecido pelas obras A Cinza das Horas (1917) e Carnaval (1919), ambos editados com recursos próprios e da família; Os Sapos (1922), O Ritmo Dissoluto (1924), Libertinagem (1930), Estrela da Manhã (1936), Crônicas da Província do Brasil, (prosa, 1937) e Guia de Ouro Preto (prosa, 1938).

Mario Sette e Lucilo Varejão, ao contrário, conviveram com o Movimento Regionalista e a inauguração do modernismo em Pernambuco. O primeiro, filho da elite, alcançou projeção com romances e contos regionalistas, publicando entre as décadas de 1920 e 1950 em periódicos locais, do Rio de Janeiro e São Paulo. Faleceu na década de 1950 e sua obra caiu no esquecimento. Foi o maior dos colaboradores pernambucanos da Esfera, apresentando três artigos: a crônica Mês Mariano, um capítulo do romance Azevedo do Poço e o conto Trem Perdido.

Lucilo Varejão foi um influente crítico de artes no Recife; a obra de Mário Souto Maior, o mais jovem, transitava em periódicos de diferentes posições ideológicas, mas Álvaro Lins, Paulo Cavalcanti e Deolindo Tavares foram militantes do Partido Comunista, e representantes da nova geração do modernismo nordestino.

Os baianos que colaboraram na Esfera foram José Alves Ribeiro (Camisão/BA, 1909 - Rio de Janeiro/RJ, 1978), Aydano do Couto Ferraz (Salvador/BA, 1914 - 1985), Barreto de Araujo, Edgard Bahiense D'Almeida Vitor (Salvador/BA, 1914 - Brasília/DF, 1983), Oswaldo Dias da Costa (Salvador/BA, 1907 - Rio de Janeiro, 1979), Edison Carneiro (Salvador/BA, 1912 - Rio de Janeiro/ RJ 1972), Fernando Góes (Salvador/BA, 1915 - São Paulo/SP, 1979), Jorge Amado (Itabuna/BA, 1912 - Salvador, 2001), Reginaldo Guimarães (c. 1910), Walter da Silveira (Salvador/BA, 1915 1970) e Wilson Woodrow Rodrigues (Salvador/BA, 1916 - c. 2000).

A maioria destes fez parte da Academia dos Rebeldes, atuou na imprensa e estudava as questões referentes à valorização da cultura africana no Brasil. Jorge Amado ainda não era o escritor consagrado que é atualmente quando publicou dois contos na Esfera (Volta e Noite de Caes) e o citado artigo Retrato do Pintor Leopoldo Mendez. Já havia, no entanto, publicado seis romances, entre eles Jubiabá (1935), Mar Morto (1936) e Capitães de Areia (1937). Filho do fazendeiro de cacau 
João Amado de Faria, fez o curso secundário em Salvador e o início da década de 1930 mudou-se para o Rio de Janeiro, onde estudou Direito e teve os primeiros contatos com o Partido Comunista, onde militou até a década de 1950. Em Salvador, foi um dos jovens fundadores da Academia dos Rebeldes.

Aydano do Couto Ferraz, filiado há um ano no Partido Comunista, transferiu-se em 1936 para o Rio de Janeiro onde trabalhou como encarregado de publicidade na livraria José Olympio e colaborou em jornais de todo o País: foi redator-chefe da revista Pan, dirigida por Sebastião Hersen de Oliveira; redator do Observatório Econômico e Financeiro, dirigida por Valentin Rebouças; secretário e depois redator chefe da revista literária Leitura, dirigida por J. Barboza Melo e chefe de redação e colaborador da revista Esfera, além de ter realizado diferentes trabalhos na área literária e jornalística. Foi autor de Canções do Beco, publicado em 193994, Mirante dos Aflitos, de 1960 e Bumba mеи Boi, de1973 (SEIXAS, 2004).

Edgard Bahiense d'Almeida Vitor, também conhecido como Tíbias Flores, contribuiu para a Esfera com os seguintes textos: A Experiência da Adolescência em Gorki (artigo), O Destino de nosso Amor (poesia) e uma descrição da cidade portuguesa Coimbra. Neste mesmo ano foi lançado no Rio de Janeiro aquele que pode ter sido o seu primeiro trabalho publicado: com o título Salazar, o livro integrava a série Figuras contemporâneas: Estadistas, da Editora Norte. Além desta, escreveu outras biografias, entre elas a de Silvio Romero, para a coleção Homens do Brasil, da editora Minerva ${ }^{95}$. Bacharel em direito, foi jornalista, historiador e escritor. Em 1959 foi admitido como funcionário da NOVACAP, tendo posteriormente publicado sua História de Brasília (1980), local onde viveu até falecer. É membro da Academia de Letras de Brasília (OLIVEIRA, 2005: 99).

José Alves Ribeiro foi um dos líderes da Academia dos Rebeldes,

A década de 20, aliás, e uma boa parte da seguinte, foi para Alves Ribeiro ativa em sua vida intelectual. É de 1928 o lançamento da primeira revista modernista baiana, ligada aos Poetas da Baixinha, Samba - Mensário Moderno de Letras, Artes e Pensamento (nov. 1928), onde publica o manifesto "Samba". É o ano da fundação com um grupo de outros jovens, da Academia dos Rebeldes (1928-1932), se fez presente no único número da revista modernista baiana “Meridiano” - Revista de Vanguarda (nº 1, set. 1929). (...) Poeta, cronista e ensaísta, Alves Ribeiro era o grande líder da Academia dos Rebeldes. Colaborou em diversos periódicos: A Luva, Etc., Meridiano, O Momento, O Estado da Bahia, Diário da Bahia,

\footnotetext{
${ }^{94} \mathrm{Na}$ Esfera número 8:36 há uma crítica de Silvia sobre Canções do Beco.

${ }^{95}$ Editora Minerva, Rio de Janeiro, 1952.
} 
Flama, A Noite, A Bahia, Diário da Tarde (Ilhéus) e em outros Estados. No Rio de Janeiro, colaborou nos periódicos Dom Casmurro, Boletim de Ariel e O Malho. ${ }^{96}$

Fernando Góes passou a maior parte de sua vida em São Paulo, onde foi jornalista em importantes órgãos da imprensa local. Cronista, crítico literário, ensaísta e poeta, foi também professor de jornalismo da Universidade Católica e da Escola Cásper Líbero e membro do Instituto Histórico e Geográfico de São Paulo e da Bahia. Publicou na Esfera a crônica O Poeta Imigrou, sobre a mudança do poeta Rossine Camargo Guarnieri de São Paulo para o Rio de Janeiro e as dificuldades para se viver de literatura e jornalismo. Deixou importante contribuição à crítica e à historiografia literária brasileira do século XX, com trabalhos de relevo sobre o Simbolismo e o Pré-Modernismo. Como cronista publicou Histórias Reais (1958) e O tecedor do tempo (1969). Foi membro das academias santista e paulista de letras. Venceu o Prêmio Jabuti (1967) e o Prêmio Governo do Estado de São Paulo por seu livro O espelho infiel (1966). Em 1969 foi premiado pela Academia Brasileira de Letras (OLIVEIRA, 1998).

O poema Visão, publicado na Esfera número quatro é assinado por Wilson Rodrigues. Podemos supor que o autor é Wilson Woodrow Rodrigues, poeta e colaborador na imprensa carioca, descendente da elite baiana que residia, provavelmente como estudante, no Rio de Janeiro. Seu nome consta na Bibliografia organizada pelo Instituto Nacional do Livro na década de 1960, sob a responsabilidade de Áureo Ottoni, proprietário da editora da Esfera, como autor do livro infantil Contos, cuja $2^{\text {a }}$ edição (publicada em 1960 pela editora Torres do Rio de Janeiro) foi ilustrada por Percy Lau. Na foto de amigos e equipe do Pequeno Dicionário de Aurélio Buarque de Holanda, publicada no livro Marulheiro ${ }^{97}$, Wilson Woodrow Rodrigues aparece ao lado de outros colaboradores da Esfera, como Carlos Drummond de Andrade, Graciliano Ramos, Marques Rebelo, Melo Lima, Rubem Braga e Vinicius de Moraes $^{98}$. Em 1944 publicou o livro de poesias Pai João, pela editora A Noite do Rio de Janeiro, cidade onde viveu até falecer no início do século XXI e que foi sua primeira publicação na área para a qual iria se dedicar no futuro. Participou em 1951 do I Congresso Brasileiro de Folclore e foi um dos fundadores da União Brasileira dos Escritores, em 1958. Poeta e folclorista, Wilson Woodrow Rodrigues foi membro da Comissão Nacional de Folclore do Instituto Brasileiro de Educação, Ciência e Cultura (IBECC-UNESCO) e de outras instituições culturais estrangeiras, tendo, durante o governo de Getúlio Vargas, desempenhado funções na

\footnotetext{
96 SANTOS, Gilfrancisco. O Rebelde Alves Ribeiro. Disponível em: <http://sergipeeducacaoecultura.blogspot.com/2010/11/o-rebelde-alves-ribeiro.html>. Acesso em: 05/09/2018.

${ }^{97}$ FILHO, M. V. Marulheiro, viagem através de Aurélio Buarque de Holanda. 1a. ed. Maceió: Edufal, 2008.

${ }^{98}$ Moraes, Vinicius. Soneto, Esfera, Rio de Janeiro n.9, março/1944:56.
} 
Embaixada do Brasil na República da Tchecoslováquia. É autor de mais duas obras sobre cultura popular: Folclore coreográfico do Brasil (1953) e Romanceiro tradicional do Brasil (século XIX) (1951), (LANTEUIL, 1944).

Walter da Silveira colaborou com a poesia Palavras de despedida e o artigo Revelação de Zola. No ano seguinte, Barreto de Araújo escreveu sobre ele na revista Dom Casmurro: “Os seus poemas são gritos surdos, abafados, do seu interior. Que importam as tragédias humanas se ele enxerga na sua desventura uma tragédia muito mais cruel?"99.

\begin{abstract}
Diplomado pela Faculdade de Direito da Bahia em 1935, foi advogado dos operários e favelados, professor, crítico, ensaísta, pesquisador, cineclubista, um dos mais lúcidos e ativos dos teóricos do cinema. Walter da Silveira produziu seu primeiro artigo sobre cinema aos vinte anos de idade, no jornal da Associação Universitária da Bahia, sob o título O Novo Sentido da Arte de Chaplin, numa reflexão crítica a respeito do filme Tempos Modernos. ${ }^{100}$
\end{abstract}

As duas gerações de alagoanos que colaboraram na Esfera participaram do movimento regionalista, mas no final da década de 1930 já estavam ausentes do Estado: Judas Isgogorota (pseudônimo de Agnelo Rodrigues de Melo, 1901 - 1979) e Joaquim Maciel Filho (1902 - 1966) moravam em São Paulo e Graciliano Ramos (1892 - 1953), Jorge de Lima (1893 - 1953), Arthur Ramos (1903 - 1949) e Medeiros Lima (1916 - 1976), no Rio de Janeiro.

A obra dos mais velhos, Arthur Ramos, Graciliano Ramos e Jorge de Lima, já era conhecida. Graciliano, havia sido prefeito de Palmeira dos Índios e funcionário da Imprensa oficial de Alagoas e seus textos já apareciam nos jornais do Rio de Janeiro desde 1906, quando estreou na revista Fon Fon. Simpatizante do Partido Comunista, dialogava com a segunda geração do modernismo nordestino e se tornou um dos grandes escritores do romance regionalista da década de 1930. Vidas Secas, sua obra prima, havia sido lançada aquele ano no Rio de Janeiro e foi comentada na Esfera no artigo Vidas Secas, Romance Direto, de Tulio Hostilio Montenegro e em Vidas Secas de Graciliano Ramos, de Eneida de Moraes que, segundo Salla, foi "o primeiro texto crítico sobre a obra de Graciliano a ter ressonância em Portugal" (SALLA, 2016:105). Os portugueses Abel Salazar e Afonso de Castro Senda também escreveram sobre ele na Esfera: o primeiro publicou Millet $e$ Graciliano Ramos, para “aproximar a obra que mais admira da moderna literatura brasileira à

\footnotetext{
${ }^{99}$ ARAÚJO, Barreto. Dois poetas diferentes, Dom Casmurro, 09/09/1939:11.

${ }^{100}$ SANTOS, Gilfrancisco. O Rebelde Walter da Silveira (1915-1970). Disponível em:<http://sergipeeducacaoecultura.blogspot.com/2010/01/o-rebelde-walter-da-silveira-1915-1970.html>. Acesso em: $13 / 09 / 2018$.
} 
produção engajada do artista plástico francês Jean-François Millet (1814-1875)" e o segundo lhe dedica o poema Descoberta do caminho impossível.

O médico Jorge de Lima (1893 - 1953) publicou na Esfera os contos À meia noite, em outubro, ao sudoeste e Era uma vez uma menina sádica; um trecho do romance A Mulher Obscura publicado em 1939 pela Livraria José Olympio Editora e o artigo sobre artes visuais, Confusão, confusão, confusão ${ }^{101}$. Clinicava no Rio de Janeiro desde o início da década de 1930, tendo alcançado prestígio no meio literário: seus poemas e nome eram citados e comentados nos mais diversos periódicos da capital e seu consultório na Cinelândia foi um ponto de encontro que introduziu muitos intelectuais recém chegados à cidade, principalmente daqueles com quem conviveu em Maceió, ao mundo das artes local. Em 1938, como sabemos, estava lançando o livro A túnica inconsútil, comentado na Esfera por Dias da Costa. A obra representa uma fase de sua carreira na qual se volta para o catolicismo. Aspectos Do Aniquilamento da Vontade Humana na Literatura, o artigo de José Santa Rita, enviado de Portugal especialmente para a Esfera, comenta o seu livro Calunga, escrito e publicado em 1935.

Os jornalistas Joaquim Maciel e Judas Isgorogota viviam em São Paulo, onde atuavam na imprensa e participavam do Grupo Baruel.

Dos cinco colaboradores provenientes de Sergipe, Cleómenes Campos (1895 - 1968), o mais velho dentre eles, já vivia há mais de duas décadas em São Paulo e era um autor prestigiado no mundo literário do Sul e Sudeste, premiado em 1923 e 1926 pelas academias sergipana e paulista de letras.

Omer Mont'Alegre, Joel Silveira e José Sampaio, representam uma nova geração de sergipanos: atuantes na imprensa local no final dos anos 1920, participaram do debate político e se engajaram, Joel e José Sampaio no PCB e Omer foi figura de proa no integralismo sergipano, diretor do jornal O Sigma e fundador do Centro de Estudos Plínio Salgado dessa capital. É o único colaborador da Esfera que não comungava dos ideais antifascistas da revista. Joel, redator da Dom Casmurro, foi o que mais publicou na Esfera e o que publicou mais livros.

O Ceará está representado com os poemas de Carvalho Junior (1895 - 1959), Celso Augusto (1904 -?) e Aluízio Medeiros (1918-1971), e a ilustração de Vicente Leite (1900-1941). Possivelmente Melo Lima (futuro diretor da revista Leitura, editada pelo PCB), seja também cearense. Este autor foi atuante na imprensa carioca entre o final da década de 1930 e 1940, tendo colaborado com críticas literárias e contos na Dom Casmurro, Fon Fon e Anuário Brasileiro de

${ }^{101}$ Esfera, Rio de Janeiro, n. 9, março/1944: 50. 
Literatura. Na Esfera publicou a crítica ao romance Estrada Perdida, de Telmo Vergara, com o título Luiz é um menino Tímido.

Aluízio Medeiros Carvalho Junior era advogado e Celso Augusto atuava há alguns anos como médico: ambos se tornaram na década de 1950 profissionais prestigiados em suas áreas, o primeiro chegou a ser Ministro do Trabalho e o segundo médico sanitarista do Ministério da Saúde.

Antônio Joaquim Pereira da Silva (1876 - 1944) e José Lins do Rego (1901 - 1957), são os paraibanos que colaboraram com obras ficcionais na Esfera. Pereira da Silva já tinha 66 anos e uma longa carreira literária e jornalística iniciada como crítico literário nos jornais cariocas $A$ Cidade do Rio, Gazeta de Notícias, Época e Jornal do Comércio. Passou sua vida nesta capital, para onde se mudou ainda criança. Viveu da poesia e jornalismo, e quando escreveu para a Esfera ocupava há cinco anos uma cadeira na Academia Brasileira de Letras. O trabalho de José Lins do Rego começou a aparecer no Rio de Janeiro na década de 1920: publicava poemas e críticas de sua autoria e sua obra era alvo de comentários e críticas publicados no Jornal A. B. C. (1929), na Revista Estética, dirigida por Prudente de Moraes Neto e Sérgio Buarque de Holanda (1924/1925), em O Jornal (1928) e no jornal A Ordem, dirigido por Tristão de Athaíde e Perillo Gomes (1929). Funcionário público, transferiu-se para o Rio de Janeiro em 1935, integrando-se ao meio intelectual carioca e colaborando em diferentes periódicos com crônicas diárias. De 1931 a 1938 escreveu sete romances, sendo que o último, Pedra Bonita ${ }^{102}$, comentado por Dias da Costa na Esfera, trata de sua vida no agreste nordestino.

Dois autores são naturais do Rio Grande do Norte: o então estudante de direito João Augusto Seabra de Melo, com a crítica $O$ caso Rachel de Queiroz e o médico Peregrino Junior, com o artigo Fundamentos Econômicos da Literatura Brasileira. Na década de 1930, Seabra de Melo escrevia na seção de Literatura do Jornal A República, criada pelo conterrâneo Luís Câmara Cascudo, onde apresentava uma postura crítica ao modernismo paulistano. Peregrino Junior mudou-se ainda jovem para Belém do Pará, onde também esteve em contato com Oswaldo Orico, colaborador da Esfera, e foi com ele um dos fundadores da, já citada, revista Guajarina.

Do Sudeste, região que sediava a editora da Esfera, veio a maioria dos seus colaboradores: vinte e dois eram fluminenses ${ }^{103}$ e moravam na cidade; dezesseis eram paulistanos, sendo que três

102 REGO, J.L. Pedra Bonita, Livraria José Olympio Editora, 1938.

103 Álvaro Moreyra, Phocion Serpa, Gilka Machado, Anna Amélia de Queiroz Carneiro de Mendoça, José Geraldo Vieira, Antônio Dias Tavares Bastos, Fábio Crissiuma, Silvia de Leon Chalreo, Maria Jacintha, Paschoal Carlos Magno, Joaquim Ribeiro, Marques Rebelo, Maria da Gloria Rangel Almeida Portugal, Iva Weisberg, Maria Violeta Coutinho, Antonio de Pádua, Eliezer Burla, Mario Brasiani, Rui de Carvalho e Fábio Leite Lobo. Não encontramos dados biográficos sobre Danilo Bastos, Heitor Lúcio, Helio Peixoto, Nilo da Silveira Werneck e Sergio Soares, moradores do Rio em 1938. 
moravam no Rio e treze na capital paulista ${ }^{104}$; Rubem Braga e Túlio Hostilo Montenegro nasceram no Espírito Santo e Amadeu de Queiroz, Emil Fahrat (habitantes de São Paulo), Murilo Mendes e Carlos Drummond de Andrade (viviam no Rio de Janeiro) e Henriqueta Lisboa (vivia em Belo Horizonte), eram mineiros. Escreveram também da capital paulistana os sergipanos Cleómenes de Campos e Joel da Silveira, os alagoanos Joaquim Maciel Filho e Judas Isgogorota, o baiano Fernando Góes e o paranaense Odilon Negrão, membros do Grupo Baruel.

Os colaboradores que viviam no Rio de Janeiro eram jornalistas, escritores e artistas que frequentavam as rodas do Bar Amarelinho e a redação da Revista Dom Casmurro, estudantes que moravam ou trabalhavam na Casa do Estudante do Brasil ou integravam o movimento da juventude do PCB, diplomatas e escritores estrangeiros ligados a partidos de esquerda em seus países de origem e mulheres que participavam do movimento feminista ou tinham ligações com o Partido. Mais da metade era composta por imigrantes brasileiros e estrangeiros ${ }^{105}$.

O primeiro número da Esfera é aberto com a citada crônica Rosas Vermelhas, de Rubem Braga. O capixaba morava no Rio de Janeiro desde os tempos de ginásio e ficou conhecido nas rodas de boemia do Bar Amarelinho. Com 25 anos de idade e um livro publicado, $O$ Conde $e o$ passarinho ${ }^{106}$, já gozava de prestígio no mundo jornalístico, principalmente pelo seu trabalho nos Diários Associados, onde fez um grande público. Textos que expressavam oposição ao regime de Getúlio Vargas lhe renderam alguns dias na prisão, em 1935. Com o paulista Oswald de Andrade e o mineiro Carlos Drummond de Andrade, forma o pequeno grupo de colaboradores nascidos no Sudeste consagrados pela crítica e historiografia da literatura brasileira, que durante os anos 1930 e 40 se alinhavam ao ideário comunista.

Alfonso Catá residiu na cidade exercendo funções diplomáticas e Enrique Fabregat exilou-se do Uruguai por questões políticas. Amadeu Amaral Junior, Arthur Ramos, Fábio Crissiuma, Medeiros Lima, Rubem Braga, Graciliano Ramos, Eneida e Rossine Camargo Guarnieri foram presos no Rio

\footnotetext{
104 Afonso Schmidt, Oswald de Andrade, Washington Azevedo, Geraldo Ferraz, Julieta Bárbara, Edgard Cavalheiro, Sangirardi Junior, Miroel Silveira, Oswald de Andrade Filho, Mario Donato, Ivani Ribeiro, Paulo Zing e Lygia de Azevedo Fagundes (Lygia Fagundes Telles) Jarbas Andrea, Amadeu Amaral Junior e Rossine Camargo Guarnieri. Com exceção dos três últimos, que viviam no Rio de Janeiro, todos os outros moravam em São Paulo em 1938.

105 Afonso de Castro Senda, português, Alfonso Hernandez Catá, cubano, Enrique Rodriguez Fabregat, uruguaio, o peruano Percy Lau que residia no Brasil desde 1921, Mario Antônio Barata, nascido na Suíça e Elisa Lispector, na Ucrânia; Eneida, Benjamim Lima e Nair Batista do Pará e Oswaldino Ribeiro Marques, do Maranhão; quatro alagoanos, Arthur Ramos, Jorge de Lima, Medeiros Lima e Graciliano Ramos; três baianos, Jorge Amado, Wilson Rodrigues e Oswaldo Dias da Costa; dois cearenses, Vicente Leite e Melo Lima; dois paraibanos, José Lins do Rego e Ademar Vidal, três pernambucanos, Paulo Cavalcanti, Manoel Bandeira e Deolindo Tavares, um potiguar, Peregrino Junior, dois sergipanos, Joel Silveira e Omer Mont'Alegre; três gaúchos Sady Garibaldo, Jeanette Budin e Paulo Corrrea Lopes, um capixaba, Rubem Braga, três paulistas, Amadeu Amaral Junior, Rossine Camargo Guarnieri e Jarbas Andrea e dois mineiros, Carlos Drummond de Andrade e Murilo Mendes.

${ }^{106}$ Reunião de crônicas editadas pela José Olympio em 1936.
} 
de Janeiro, após o levante comunista de 1935. Omer Mont'Alegre foi o único entre eles que se mudou para o Rio de Janeiro em decorrência da repressão movida pelo governo de Getúlio Vargas em resposta à insurreição integralista de 1938, que resultou na extradição do líder Plínio Salgado para Portugal e em muitas prisões de militantes do movimento.

A Esfera traz contribuições de jornalistas, escritores e artistas paulistas, a maioria residente na capital do estado e engajados no PCB, como os consagrados Oswald de Andrade, com o capítulo do romance Suicídio de Lindaura e Afonso Schmidt, com os poemas Formas, Zungu e Gheto e uma crítica sobre o livro de poemas Terra, de Mário Donato. Este último era um jovem integrante do Grupo Baruel, assim como a maior parte dos colaboradores da revista que moravam nesta capital. Afonso Schmidt (1880 - 1964) já era um autor prestigiado. Em 1935, quando a Revista o Cruzeiro anunciou o lançamento do livro Curiango, editado pela José Olympio, seus contos e poemas foram equiparados aos de Mário de Andrade e Monteiro Lobato que, segundo o autor do artigo, formavam com ele "o grande trio de conteurs de sua geração"107. De origem humilde, manifestava em seu trabalho como jornalista, contista e romancista a preocupação com os pobres, os excluídos da sociedade, apontando em seus versos desigualdades e injustiças sociais. Em 1907 excursionou quatro anos pela Europa, sem dinheiro e sem passaporte. De volta ao Brasil, publicou seu primeiro livro de poesia, Janelas Abertas (1911). Entre 1918 e 1924, foi diretor do jornal Voz do Povo, da Federação Operária, no Rio de Janeiro ${ }^{108}$.

Outro membro do Baruel colaborador da Esfera foi o poeta paulista Rossine Camargo Guarnieri que, como citado anteriormente, havia publicado no mesmo ano seu livro de estreia Porto Inseguro, prefaciado por Mário de Andrade ${ }^{109}$, gerando grande polêmica pela forte conotação social e ligação com o ideário comunista. Assim como eles, colaboraram com a revista os seguintes migrantes que se reuniam na Baruel: Cleómenes Campos de Oliveira, Joaquim Maciel Filho, Joel Silveira (que na época vivia no Rio, mas tinha passado por São Paulo), Judas Isgorogota, e Odilon Negrão.

Dos quatro mineiros que colaboraram com a Esfera, apenas Henriqueta Lisboa (1901 - 1985) residia em Belo Horizonte. O farmacêutico Amadeu de Queiroz (1873 -1955), o mais velho, aos 43 anos de idade havia se mudado, por questões políticas, de Pouso Alegre, sua cidade natal do interior de Minas Gerais, para São Paulo, onde passou o resto da vida. Desde a última década do século XIX,

${ }^{107}$ CURIANGO, Afonso Schmidt. O Cruzeiro, Livros Novos, 09/11/1935:53.

${ }^{108}$ ENCICLOPÉDIA Itaú Cultural de Arte e Cultura Brasileiras. Afonso Schmidt. Disponível em: <http://enciclopedia.itaucultural.org.br/pessoa3128/afonso-schmidt>. Acesso em: 3 setembro 2018.

${ }^{109}$ Mário de Andrade era amigo do músico Mozart Camargo Guarnieri, irmão de Rossine. 
publicava adaptações de contos populares, versos românticos e parnasianos, artigos sobre livros e resenhas literárias (a maioria inéditos), em jornais de Pouso Alegre, do interior do Estado e das capitais mineira e paulista, e se correspondia com escritores destes dois Estados. Em 1938 estava lançando seu livro de maior sucesso, A Voz da Terra, que alcançou grande repercussão, lhe rendendo elogios da crítica e menção honrosa da Academia Brasileira de Letras (GUIMARÃES, 1992). Segundo Mário da Silva Brito, em artigo do Correio da Manhã, "A Voz da Terra foi talvez o romance de maior êxito de crítica destes últimos tempos” e os “artigos assinados saídos na imprensa do Brasil e do estrangeiro [sobre A Voz da Terra] dariam um volume de 300 páginas ou mais ${ }^{110 " . ~}$

Carlos Drummond de Andrade transferiu-se para o Rio de Janeiro em 1934, para trabalhar como chefe de gabinete do Ministro de Educação e Saúde Pública do governo Vargas, Gustavo Capanema. Se relacionava com o então ministro desde meados da década de 1920 em Belo Horizonte, nos encontros literários do Grupo do Estrela e com ele iniciou sua carreira no funcionalismo público, como oficial de seu gabinete de Secretário do Interior do Estado de Minas Gerais (1930). Drummond tinha grande afeto por Silvia, o que demonstra nas poesias dedicadas a ela e na correspondência conservadas no acervo. Colaborou cinco vezes com a Esfera, duas delas - O Cotovelo Dói e A Noite Dissolve os Homens, no período ora estudado, e as outras três em edições da década de 1940. Ainda não era o poeta consagrado que viria a ser, mas já havia causado polêmica ao publicar o poema No meio do caminho na Revista de Antropofagia, em 1928, e conquistado prestígio pelos livros Alguma poesia (1930) e Brejo das Almas (1934). Seu arquivo pessoal pertence a Fundação Casa de Rui Barbosa, Rio de Janeiro.

Emil Fahrat foi o mais jovem colaborador mineiro, com 24 anos publicou na Esfera uma crítica à obra de Coelho Neto, Coelho neto pisou sobre tesouros, Da página sessenta, capítulo do seu romance Cangerão publicado em 1938 e Então fiscalizem as Marias, artigo onde discute a legalização do divórcio. Havia se mudado para o Rio de Janeiro em 1932, onde cursou a faculdade de Direito e atuou, enquanto estudante, no jornalismo político. Após formado ingressou no ramo publicitário, no qual fez carreira.

Souza Junior (1896 - 1945), Paulo Correa Lopes (1898 - 1957), Athos Damasceno (1902 1975), Érico Veríssimo (1905 - 1975), Odilon Negrão (1908 - 1991), Sady Garibardi (1909 - 1959), Telmo Vergara (1909 - 1967), Hamilcar de Garcia (1913 - 1991) e Jeanette Budin (1914 - 1953) representam na Esfera os autores nascidos no Rio Grande do Sul e Maura de Senna Pereira (1904 1991) é a única representante de Santa Catarina.

${ }^{110}$ BRITO, Mario da Silva. A quinzena literária e artística de São Paulo, Correio da Manhã, 18/02/194:8. 
Os autores gaúchos também tinham vínculos ideológicos com as posições antifascistas dos editores da Esfera e atuavam no mundo jornalístico e literário. O consagrado Érico Veríssimo teve sua carreira profissional vinculada à Editora Globo, onde começou a trabalhar logo que se mudou de sua cidade natal no interior do Estado para a capital. Mas ele não era o único entre estes autores sulistas prestigiado na época e com grande aceitação pelo público leitor: a obra de Telmo Vergara era conhecida não apenas no Rio Grande do Sul, mas em todo o Brasil, principalmente após 1936, quando sua coletânea de contos Cadeiras na Calçada ganhou o prêmio Humberto Campos, promovido pela José Olympio Editora. O esquecimento de sua obra é tratado em A Estrada Perdida de Telmo Vergara, tese de doutorado de Fábio Augusto Steyer (STEYER, 2005).

Além de escritores já prestigiados, publicaram autores conhecidos no meio literário, jornalístico ou artístico na época e há entre eles os que conquistaram prestigio nas décadas seguintes. Hoje a obra, movimentos e ideias compartilhadas pela maior parte deles são desconhecidas.

Um fator que favoreceu este esquecimento foi a destacada participação de jovens estudantes vinculados à militância política, que durante este período da vida produziram contos, poemas e críticas literárias, mas que acabaram não seguindo carreira literária; e de mulheres, que por sua própria condição de gênero ficaram esquecidas pela história.

\subsection{1 - Estudantes}

Mais de um terço dos colaboradores da Esfera tinha menos de 25 anos de idade, sendo que a maioria é composta por jovens estudantes, grande parte militantes ligados ao PCB e, entre os residentes no Rio de Janeiro, com vínculos com a Casa do Estudante do Brasil.

Anna Amélia Carneiro de Mendonça, com quem Sylvia se relacionava desde os idos do Athenée foi, como sabemos, uma das fundadoras da primeira associação nacional de estudantes, a Casa do Estudante do Brasil, e sua presidente até 1971. Criada em 1929, a instituição era subvencionada pelo governo federal e se voltava principalmente à assistência aos estudantes, tornando-se conhecida por seus recitais, quermesses, torneios esportivos e iniciativas de assistência aos estudantes mais pobres ${ }^{111}$. Mas era ao mesmo tempo um ponto de encontro onde diferentes posições políticas e artísticas dialogavam, pois mantinha um refeitório universitário bastante frequentado, residência estudantil, escritório de intercâmbio com outras entidades estudantis nacionais e internacionais, um departamento que ajudava os estudantes na busca por emprego,

111 Cunha, L. A. Casa do Estudante do Brasil. In: CPDOC-FGV, Casa do Estudante do Brasil, Verbete Temático. Disponível em: <http://www.fgv.br/cpdoc/acervo/dicionarios/verbete-tematico/casa-do-estudante-do-brasil〉. Acesso em $19 / 02 / 2019$. 
departamento cultural, salas onde se instalavam diferentes associações estudantis e ambulatório médico. No final da década de 1930 foi politicamente ativa: em 1937 sediou e colaborou com a organização do I Congresso de Estudantes do Brasil, no ano seguinte com a segunda versão do evento, momento onde se deu a criação da União Nacional dos Estudantes e em 1939, ao completar 10 anos de existência, promoveu a Conferência Pan Americana de Estudantes. Há informações sobre a participação de dois colaboradores da revista nestes eventos, o maranhense Oswaldino Marques Ribeiro e Yva Weisberg, representante da União Universitária Feminina, uma das associações sediadas na CEB.

Cláudio Sinfrônio Medeiros Lima era estudante de Direito quando colaborou com a Esfera com o trecho do romance Juventude Morta, ilustrado pelo pernambucano Augusto Rodrigues, e com o conto Lembrança de uma página de diário, ilustrado por Percy Lau. Nascido em Maceió, mudouse para o Rio de Janeiro em meados da década para fazer o curso superior e residia na Casa do Estudante, trabalhando como secretário da presidente e produzindo o boletim da entidade. Envolvido no movimento estudantil, havia participado do comitê organizador do I Congresso da Juventude do Brasil, evento que desde 1934, com o apoio da juventude comunista e ANL, promoveu manifestações antifascistas no Norte e Nordeste do país. O congresso teve grande repercussão, mas não se realizou em consequência da repressão à intentona de 1935, com o fechamento de todas as associações ligadas ANL e prisão de muitos estudantes. Medeiros Lima provavelmente foi um deles, pois em 18 de dezembro de 1935 o jornal Diário da Noite do Rio de Janeiro, no artigo Correspondência para os presos políticos $^{112}$, inclui seu nome na lista de destinatários encarcerados no presídio da Ilha das Flores. Em 1938, ainda trabalhava na Casa do Estudante, onde dividia com Paschoal Carlos Magno a direção do Departamento Cultural.

Nesse ano o departamento promoveu a exposição do artista recifense Luis Soares e criou o Teatro do Estudante: após três meses de ensaio no Teatro João Caetano sob a direção de Italia Fausta, esta iniciativa resultou na apresentação por um grupo de mais de 200 estudantes (entre atores, músicos, coristas e dançarinos) de Romeu e Julieta, de Shakespeare. Mário Brasini, que aos 17 anos publicou na Esfera o poema As Almas que ainda não nasceram, foi um dos primeiros colaboradores do teatro do estudante e, em 1940, o autor da primeira peça de teatro criada, representada e dirigida por estudantes no Rio de Janeiro, a comédia em três atos, Estudantes (FERREIRA, 2010). Foi produtor e escritor de rádio novelas, ator da Companhia Atlântida Cinematográfica, diretor artístico da TV Tupi, novelista das rádios Mundial e Mayrinque Veiga, produtor cinematográfico e inventor.

\footnotetext{
${ }^{112}$ Correspondência para os presos políticos. Diário da Noite, 18/12/1935:3.
} 
Filho do arquiteto italiano Ferrucio Brasini e da alagoana Dulce Brasini, passou sua primeira infância entre capitais do Nordeste e dos oito aos treze anos viveu entre a França e a Itália.

Sangirardi Junior era estudante de direito em São Paulo. Colaborador desde 1935 da Folha da Noite, escrevia na revista Problemas, que tinha em sua direção, conselho e corpo de colaboradores intelectuais próximos ou militantes do PCB, como Oswald de Andrade, Rubem Braga e Afonso Schmidt. No início da década de 1940 assumiu a direção a sucursal de São Paulo do jornal Diretrizes, também vinculado ao $\mathrm{PCB}^{113}$.

Proveniente do movimento estudantil no Nordeste, o pernambucano Paulo Cavalcanti estudava na Faculdade de Direito de Recife, fazia parte da Casa do estudante de Pernambuco e atuava, combatendo sempre as teses fascistas, no diretório estudantil da faculdade. Escreveu para Dom Casmurro e Esfera, do Rio de Janeiro e Seiva, de Salvador, todos com ligações com o PCB.

Aluízio Medeiros foi jornalista e poeta. Quando publicou na Esfera a poesia Seguirei Tranquilo $^{114}$, era estudante da Faculdade de Direito do Ceará, onde se envolveu com o movimento estudantil. Posteriormente participou do PCB.

Edgard Cavalheiro, estudante de Direito em São Paulo, João Augusto Seabra de Melo, do Rio Grande do Norte, Álvaro Lins, Recife, o baiano Wilson Woodrow Rodrigues, Augusto de Almeida Filho e Mário Barata, do Rio de Janeiro, também eram estudantes universitários quando colaboraram com a Esfera.

\subsection{2 - Mulheres}

Dirigida e editada por duas mulheres, Maria Jacintha e Silvia, a Esfera publicou nestes oito exemplares trabalhos de vinte e duas mulheres brasileiras e estrangeiras, assinando trinta e dois artigos em Letras, sendo a maioria poemas e críticas literárias; dez em Artes, sendo sete em Teatro e três em Artes Plásticas e, em Ciências, dois sobre folclore, um sobre direito do trabalho e outro sobre medicina. Além dessas colaboradoras, treze escritoras, artistas e cientistas foram objeto de reportagens, artigos e críticas. Uma representação feminina considerável em relação ao 247 de artigos publicados, alcançando pouco mais de $20 \%$ deste total, e um caso incomum nas publicações do Partido, que como a maioria dos periódicos, congregava em suas publicações principalmente autores e equipe executiva do sexo masculino.

\footnotetext{
${ }^{113}$ SANGIRARDI Junior. In: DICIONÁRIO Histórico Biográfico da Propaganda no Brasil. Coordenadoras Alzira Alves de Abreu e Christiane Jalles de Paula, Rio de Janeiro: Editora FGV: ABP, 2007: 221.

${ }^{114}$ Esfera, Rio de Janeiro, novembro/1939, n.8: 52.
} 
Grande parte das mulheres colaboradoras da Esfera participaram ativamente do movimento internacional de combate ao fascismo liderado pelas esquerdas e do movimento feminista internacional. Por outro lado, há um evidente interesse da editoria em divulgar a obra de outras mulheres, o que se percebe tanto pela quantidade de publicações de autoria de mulheres quanto pelas críticas dirigidas a elas, que na maioria foram escritas pelas mãos femininas de Silvia, Maria Jacintha e Eneida.

No concurso nacional de contos brasileiros realizado pela revista $O$ Malho em 1930, a comissão julgadora foi formada por quatro homens e apenas cerca de dez por cento dos 394 nomes inscritos são femininos. O resultado deste concurso, premiou quinze homens e deu menção honrosa para outros treze. A mesma revista promoveu em 1932 o concurso nacional Qual a maior das poetisas brasileiras? ${ }^{115}$ com votos espontâneos de cerca de 259 intelectuais homens, que giravam em torno de 15 nomes: Anna Amélia, Carmem Cinira, Cecília Meireles, Elza Araripe, Eneida, Gilka Machado, Henriqueta Lisboa, Hildette Faville, Ide Blumenschein, Leda Rios, Lia Correa Dutra, Maria Eugenia Celso, Palmyra Wanderley, Pagu e Rosalina Coelho.

Esta desigualdade na difusão de obras ficcionais produzidas por mulheres se repetiu ao verificarmos alguns periódicos da década de 1930 na Hemeroteca Digital Brasileira. Na página de colaboradores da primeira edição da Dom Casmurro, entre 51 nomes há apenas dois femininos: Clara Torres e Adalgisa Nery; em Diretrizes, revista de política, economia e cultura de Azevedo Amaral e Samuel Weiner não há matérias assinadas por mulheres nas nove edições publicadas em $1938^{116}$; na Revista Fon Fon, são raras as mulheres que assinam artigos ficcionais neste ano; nas edições de 1935 da revista Festa, entre cerca de três dezenas de autores aparecem apenas quatro nomes femininos: as estrangeiras Gertrude Von Le Fort, alemã, Gabriela Mistral, chilena e Joana de Ibarbourou, uruguaia, e apenas uma brasileira, a já prestigiada poetisa Cecília Meireles ${ }^{117}$.

Segundo Romanelli, até hoje, 90 anos depois,

[...] mesmo com o avanço do movimento feminista a igualdade dos gêneros ainda está longe de ser uma realidade, inclusive no mercado editorial [...] escritoras mulheres ainda são menos publicadas, recebem menos prêmios e são menos convidadas para eventos literários do que escritores homens. Personagens femininas também aparecem menos e tem menos destaque e importância do que personagens masculinos” (ROMANELLI, 2014: 43).

\footnotetext{
115 O Malho, Rio de Janeiro, 03/12/1932:12 - 13.

116 Obs.: Cerca de um terço das matérias são assinadas apenas com iniciais.

117 Gilka Machado participou da revista, mas seu nome não consta nas edições pesquisadas.
} 
Assinaram capítulos de romances, contos e poemas as brasileiras Anna Amélia Carneiro de Mendonça, Elisa Lispector, Eneida, Gilka Machado, Henriqueta Lisboa, Ivani Ribeiro, Julieta Bárbara, Lygia de Azevedo Fagundes (Lygia Fagundes Telles), Maria da Gloria Rangel Almeida Portugal, Maria Jacintha, Nair Batista e Sylvia.

Lygia, a mais jovem de todas (tinha apenas 15 anos quando colaborou com a Esfera) foi a única que ficou consagrada no mundo das letras do Brasil. Mais conhecidas naquele momento eram as poetisas Anna Amélia, Henriqueta Lisboa e Gilka Machado, cujas obras e trajetórias de vida vêm sendo estudadas nas últimas décadas, principalmente em pesquisas na área de estudos de gênero. As três foram ativistas do movimento feminista e filiadas à Federação Brasileira para o Progresso Feminino e, no plebiscito Levemos a mulher à Academia Brasileira de Letras, promovido pela $O$ Malho em 1936 com a pergunta Qual a mulher atual que merece a consagração da imortalidade?, ficaram entre as cinco primeiras colocadas. ${ }^{118}$

Anna Amélia, como sabemos, teve intensa atividade política e intelectual na capital federal. Henriqueta vivia na época em Belo Horizonte, mas tinha forte vínculo com o Rio de Janeiro, onde havia morado dos 13 aos 24 anos, época em que atuou pela emancipação feminina e iniciou sua carreira de poetisa. Colaborou com a revista Festa e seu arquivo pessoal, pertencente ao Acervo de Escritores Mineiros da Universidade Federal de Minas Gerais, guarda a vasta correspondência que manteve entre 1940 e 1945 com Mário de Andrade. Em 1936 havia publicado seu terceiro livro de poemas, Velário.

Gilka Machado fez poemas desde criança, com 13 anos ganhou os três primeiros prêmios do concurso promovido pelo jornal A imprensa e aos 22 anos publicou seu primeiro livro, Cristais Partidos. No início da década de 1930 já tinha poemas traduzidos para o espanhol e foi vencedora do concurso de maior poetisa brasileira promovido pela revista $O$ Malho, com cerca de um terço dos votos de 250 intelectuais cariocas, o que demonstra grande popularidade na época. Sua poesia caracteriza-se pelos temas eróticos e rigor formal, o que, segundo Nadia Gotlib, a faz ser conhecida “como precursora na luta pelos direitos de acesso à representação do prazer erótico na poesia feminina brasileira". Feminista militante, em 1910, foi uma das fundadoras do Partido Republicano Feminino e membro da Federação Brasileira para o Progresso Feminino (GOTLIB, s/d). Sylvia já a conhecia de longa data, pois participou da organização do evento em sua homenagem promovido pela

\footnotetext{
118 O Malho, Rio de Janeiro, 14/01/1937: 26 - 27.
} 
Revista Brasil Feminino em 1933, realizado após sua vitória no concurso de O Malho ${ }^{119}$. Na Esfera colaborou com o poema Mocambos do Recife.

Eneida (1903 - 1971) e Nair (1911 - 1983), ambas paraenses, viviam no Rio de Janeiro e foram conhecidas militantes do Partido Comunista. Na década de 1950, Nair fez parte da comitiva que levou Graciliano Ramos e outros intelectuais comunistas para a União Soviética. Alguns anos depois, na reportagem Retrato inteiro da noiva de Prestes, é apresentada como "alta funcionária federal e conhecida intelectual comunista":

\begin{abstract}
Quem é ela, na verdade? Uma intelectual, com livros de versos na mocidade - ao qual não gosta de referir-se, e que escreve nos suplementos femininos do jornal comunista Imprensa Popular. Nair Batista já promoveu mesas redondas e conferências, presididas pelo desembargador Saboia Lima, em preparação ao Congresso de Viena, em 1952, onde representou o Brasil. Funcionária federal por concurso; é arquivologista ${ }^{120}$.
\end{abstract}

Um destes poemas escritos na juventude, Acalanto do Menino, foi publicado na Esfera. Na época ela era membro da primeira equipe técnica do recém criado Serviço do Patrimônio Histórico e Artístico Nacional, onde se relacionava com Rodrigo de Melo Franco de Andrade, Lúcio Costa, Mário de Andrade e outros intelectuais modernistas que participaram da fundação dessa instituição. Neste período pesquisou sobre arte colonial brasileira junto aos arquivos eclesiásticos do Rio de Janeiro ${ }^{121}$ e, a partir da terceira edição de 1939, publicou assiduamente na Revista do Patrimônio Histórico.

Eneida de Moraes, pertencente à elite paraense enriquecida com a borracha, conheceu o Rio de Janeiro ainda jovem, onde teve contato com intelectuais modernistas. No final da década de 1920, colaborava com a revista modernista Belém Nova e já publicava na revista Para Todos, que circulava no Sudeste do País. Em 1932 mudou-se para São Paulo, onde passou a desenvolver intensa atividade política como membro da seção paulista do Partido Comunista do Brasil. Devido à sua militância, ainda em 1932 esteve por quatro meses na prisão. Em maio de 1935 ingressou na União Feminina do Brasil, associação filiada à Aliança Nacional Libertadora e ao PCB. Foi presa várias vezes durante o governo de Getúlio Vargas, e passou por sérias dificuldades: trabalhou inclusive como operária, além de tradutora e redatora de artigos políticos (PAULA, 2010). Colaborou com a Esfera oito vezes e assina o corpo de redatores em todos os números. Três delas em 1938, quando publicou o conto $O$

\footnotetext{
119 Jornal do Brasil, 16/02/1933:12.

${ }^{120}$ GUTEMBERG, Luís. Retrato Inteiro da noiva de Prestes. O Mundo Ilustrado, 23/04/1958:10.

121 "Nair Batista procedeu a um estudo acurado dos livros antigos ainda existentes nos arquivos das Ordens 3as. e irmandades a quem pertencem alguns dos monumentos de arte religiosa mais importantes desta cidade". ANDRADE, R.M.F. O mestre do mestre Valentim. A Manhã, 06/08/1943, Rio de Janeiro.
} 
Homem entre Frases, a crítica ao recém lançado Vidas Secas de Graciliano Ramos e a tradução do artigo Rumos do romance brasileiro, do argentino Newton de Freitas. Em 1946, sob o título As Nossas Companheiras, relatou na Esfera uma passagem de sua vida na prisão, quando conheceu a militante do Partido Comunista enviada com Olga Benário à Gestapo e condenada à morte, Elise Saborovski.

Ivani Ribeiro criou em 1938, na Rádio Sociedade Educadora Paulista onde trabalhava há alguns anos, os programas Teatrinho da Dona Chiquinha e A Hora Infantil, que lhe deram notoriedade. Foi neste período também que conheceu Dárcio Moreira Alves Ferreira, militante de esquerda e locutor de rádio, com quem se casou em 1941. Foi provavelmente esta aproximação com os comunistas e a popularidade na rádio que lhe proporcionou um espaço na Esfera publicando o poema Exaltação. Nos 50 anos seguintes construiu uma carreira de sucesso ganhando projeção nacional como escritora de novelas para televisão.

Através da amiga e educadora Sebastiana Teixeira de Carvalho, Julieta Guerrine, filha de um fazendeiro do interior paulista, formada pela Escola Normal e professora em São Paulo desde meados da década de 1920, conheceu pessoalmente o prestigiado escritor Oswald de Andrade, com quem se casou em 1936. Com ele, passou a circular no mundo das artes no Rio e, em São Paulo, sua casa era ponto de encontro de intelectuais de esquerda, pois no período Oswald estava engajado no PCB. Estas relações provavelmente contribuíram para que a Esfera publicasse seu poema, Jesus Errante:

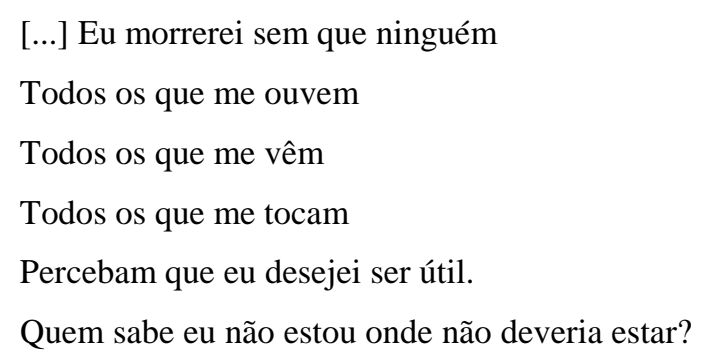

Em 1939 publicou pela Editora José Olympio seu único livro, prefaciado por Raul Bopp: Dia Garimpo. Escreveu e pintou muito mais. Sua obra, esquecida como previsto no poema, está nos arquivos da família.

Maria da Glória trabalhava como datilógrafa no Itamaraty e foi provavelmente lá que conheceu o diplomata Affonso Barbosa de Almeida Portugal, com quem se casou. Viveram entre outros países, no México, que inspirou seu romance Olhando o México, bastante comentado pela crítica e que lhe rendeu em 1942 a condecoração da Ordem Nacional da Águia Asteca conferida pelo 
governo do México ${ }^{122}$. O capítulo de seu romance publicado na Esfera com o título Fiestas em México faz parte deste livro. Poetisa, publicava em periódicos e realizava conferências sobre suas viagens e obras durante as estadias no Brasil.

Quando Elisa Lispector publicou na Esfera o conto Tédio, tinha vinte e sete anos e já vivia há três no Rio de Janeiro. Normalista, estava iniciando seu trabalho literário, colaborando com contos para a imprensa carioca. Exerceu por pouco tempo o magistério e em 1935 ingressou através de concurso no funcionalismo público, onde fez carreira. Seu primeiro romance, Além da Fronteira, foi publicado em 1945; a ele seguiram-se No Exílio (1948), Ronda Solitária (1954), O Muro de Pedras (1963), premiado duas vezes pela Academia Brasileira de Letras, O Dia Mais Longo de Tereza (1965), Sangue no Sol (1970), Inventário (1977) e O Tigre de Bengala (1985). Sua obra está também esquecida, em parte obscurecida pelo sucesso de sua irmã, a consagrada Clarice Lispector.

Sylvia assina uma crônica e o capítulo de seu romance Miramar, nunca publicado na íntegra. Além dele, foi autora de livros inéditos: o romance Contrasentido, a peça teatral Desencontro, o conto A mulher que perdeu a fala, o livro Poesias e a crônica de arte Pintura em arte. Foi também tradutora: fez a primeira tradução de $O$ Tacão de Ferro, de Jack London e dos inéditos Claridade e $O$ Inferno, de Henri Barbuse e Maria Clara, de Marguerite Audoux ${ }^{123}$. Em 1941, na carta publicada na revista Mundo Uruguaio, ela reflete sobre seu trabalho literário e indica que todo o material inédito foi descartado:

A literatura nunca me proporcionou solução satisfatória (íntima). Escrevia com toda sensibilidade e tudo permanecia meu. Realizada a exteriorização, predominava a não comunicação. Rasgar originais foi um grande trabalho. ${ }^{124}$

Em um mundo essencialmente masculino, onde só eles eram aceitos na Academia Brasileira de Letras ${ }^{125}$, análises, interpretações e críticas feitas por mulheres ainda eram raras. Escreveram críticas literárias as quatro mulheres mais fortemente ligadas à Esfera: Sylvia, Maria Jacintha, Eneida e Maura de Senna Pereira. Maura, que ainda morava em Florianópolis (só no ano seguinte se mudou para o Rio de Janeiro e integrou a equipe administrativa da Esfera) colaborou com uma crítica ao

122 OLHANDO o México. Vamos Ler, 11/04/1940:40. CARVALHO, J. O que escrevem as mulheres, A Noite, 24/03/1940: 2.

${ }^{123}$ Fonte: Acervo Silvia / Vida Profissional / Artes Plásticas / Currículo em italiano.

124 Recorte da Revista Mundo Uruguaio, 17/08/1940. Acervo Silvia.

125 Até 1951 não havia uma restrição expressa ao ingresso de mulheres na ABL, só neste ano foi incorporado ao seu regimento interno a inelegibilidade feminina. Rachel de Queiroz foi a primeira mulher a conquistar uma vaga na Academia, em 1977. Sobre as mulheres na ABL ver: Fanini, M. A. Fardos e Fardões: Mulheres na Academia Brasileira de Letras; Tese (doutorado em Sociologia), FFLCH, 2009. 
romance Xarqueada ${ }^{126}$, romance social de Pedro Wayne (outro autor esquecido pelos estudos literários) publicado em 1937, que retrata a vida dos trabalhadores das insalubres charqueadas gaúchas nas primeiras décadas do século.

\begin{abstract}
Xarqueada narra as mazelas e os sofrimentos de um grupo de homens, mulheres e crianças na lida da produção do charque, alimento que durante muito tempo sustentou a economia do Rio Grande do Sul e sucumbiu à falta de modernização do sistema produtivo e à chegada dos grandes frigoríficos. Tratadas sem piedade pelos patrões, essas pessoas acabam reproduzindo no trabalho com os animais um tratamento semelhante àquele que recebem ${ }^{127}$.
\end{abstract}

Maria Jacintha escreveu sobre as obras dos sulistas Érico Veríssimo e Telmo Vergara e das poetisas Anna Amélia e Henriqueta Lisboa; Sylvia sobre a poesia de Gilka Machado e o romance Canções do Beco, de Dias da Costa e Eneida fez a citada crítica à Vidas Secas, de Graciliano Ramos.

Foram objeto de críticas literárias Adalgisa Nery em A poesia de Adalgisa Nery, por Álvaro Lins; Lúcia Miguel Pereira, em Amanhecer, por Dias da Costa; Gilka Machado em A nova poesia de Gilka, por Sylvia; Anna Amélia de Queiroz Carneiro de Mendonça, em Anna Amélia e a Harmonia das Coisas e Henriqueta Lisboa, em $O$ Velário, ambos por Maria Jacintha; Oneyda Alvarenga, em Dois Poetas Paulistas, por Aydano do Couto Ferraz e Rachel de Queiroz, em O Caso Rachel de Queiroz, escrito por João Augusto Seabra de Melo, que no artigo a define como "uma das mais discutidas e poderosas afirmações da moderna geração de romancistas". Destas a única consagrada foi Rachel de Queiroz, que já era bastante prestigiada desde o início da década devido ao sucesso de vendas de seu premiado romance que retrata a seca e a pobreza no Nordeste, O Quinze, publicado pela primeira vez em 1930.

Oneyda Alvarenga nasceu em 1911, em Varginha, uma cidade provinciana do interior de Minas. Aos dezenove anos mudou-se para São Paulo para estudar no Conservatório Dramático Musical, onde foi aluna de Mário de Andrade, que se tornou seu grande mentor e amigo. Com seu incentivo, críticas, conselhos e comentários, escreveu e publicou em 1938 um livro de poemas, $A$ Menina Boba ${ }^{128}$ : duzentos exemplares editados a expensas da autora, numerados e assinados por ela e posteriormente musicados pelos compositores Camargo Guarnieri, Francisco Mignone, Clorinda Rosato, Cláudio Santoro, Hans-Joachim Koellreuter e Everett Helm ${ }^{129}$. Mesmo tendo recebido as

\footnotetext{
${ }^{126}$ WAYNE, P. R. Xarqueada. 1a. ed. Rio de Janeiro: Editora Guanabara, 1937.

127 ALVES, M. M. Xarqueada, de Pedro Wayne: Um Romance Proletário? Cenários, Porto Alegre, vol. 1, nº 15, 2017 : $32-44$.

${ }^{128}$ ALVARENGA, Oneyda. A menina boba: poemas. São Paulo: Revista dos Tribunais, 1938.

129 BARONCELLI, N. Oneyda Alvarenga e seus poemas que foram musicados. Escrevo logo existo. Disponível em:
} 
melhores críticas, entre elas dos prestigiados modernistas Mário de Andrade, Manuel Bandeira e Sérgio Milliet (A menina boba é dedicado aos dois primeiros), esta obra é praticamente desconhecida hoje em dia. Em carta a Paulo Duarte escrita em 1939, Mário a coloca entre os mais conceituados poetas da época: "Murilo Mendes e Vinicius, e Carlos Drummond e Oneida, e Cecília Meirelles, e Adalgisa e Augusto Meyer" (ANDRADE apud CAROZZE, 2012: 40).

$\mathrm{Na}$ crítica publicada na Esfera, Aydano do Couto Ferraz, que a toma por uma talentosa e promissora autora, tece os seguintes comentários sobre sua poesia:

Adora a simplicidade e a nudez sem convencionalismos, confessa amar a vida como a vida vem a seu encontro. Sentindo seu corpo latejar de seiva, quer que a enlacem braços rijos e sente beijos loucos ao redor de $\mathrm{si}^{130}$.

Oneyda estava longe da atividade política, conforme ressalta Mário de Andrade em carta dirigida à Murilo Mendes, em 1935, acompanhando o envio de poemas da aluna para serem publicados na Revista Acadêmica:

\footnotetext{
Murilo, mando-lhe três poemas que considero absolutamente admiráveis. (...) Está certo que nem de longe estes versos são esquerdistas. Nem a Oneyda, que eu saiba, é propriamente esquerdista. Tem uma vaga tendência apenas, e mesmo está pouco se demonstra nos versos dela, geralmente falando de amor e demasiado individualista ainda (CAROZZE, 2012: 28).
}

Quando Mário se tornou diretor do Departamento de Cultura do Município de São Paulo (1935-1938), ela foi nomeada diretora da recém criada Discoteca Pública Municipal. Sua vida profissional foi de intensa dedicação aos serviços e pesquisas realizadas na instituição e sua produção poética ficou em segundo plano.

Adalgisa Nery (1905 - 1980), casada dos 16 aos 29 anos com o artista plástico Ismael Nery, participava do mundo intelectual do Rio de Janeiro, em reuniões literárias e artísticas, muitas vezes como única mulher. Ao ficar viúva com dois filhos pequenos, a até então conhecida como esposa e mãe, de mera observadora iniciou uma carreira na imprensa, publicando artigos literários. Seus primeiros contos foram veiculados na revista $O$ Cruzeiro, mas também colaborou com periódicos de esquerda, como Diretrizes e Dom Casmurro. Em 1937, publicou na Revista Acadêmica seu primeiro poema, Eu em ti, que abriu caminho para o livro de estreia organizado por Murilo Mendes publicado no ano seguinte, Poemas. É sobre este livro que Álvaro Lins escreve na Esfera no artigo A poesia de 
Adalgisa Nery, cujo trecho abaixo contém seu espanto com as qualidades da poetisa, que possui, segundo ele, "tudo o que é raro e difícil na poesia de uma mulher":

O sofrimento, a tristeza, a sensação de aniquilamento que, às vezes, dá aos seus poemas um tom de tragédia, resultam, talvez, desse choque entre a liberdade e os limites do mundo, entre o seu desejo de penetrar a origem e o fim dos seres e das coisas e os mistérios que a cercam e a angustiam, entre sua ânsia de vencer todas as fronteiras e a existência de fronteiras por toda a parte. E a sua poesia é quasi toda um longo e poderoso monólogo de quem se debate com estes limites, as fronteiras e os mistérios universais. Por isso é tantas vezes misteriosa, hermética, densa, apocalíptica e profética. Tudo o que é raro e difícil na poesia de uma mulher ${ }^{131}$.

A mais desconhecida entre elas é Lúcia Miguel Pereira, mas no artigo de Dias da Costa ele a compara com a prestigiada Rachel de Queiroz, mesmo levantando aspectos negativos de seu romance de tendência católica publicado aquele ano, Amanhecer ${ }^{132}$. Lúcia começou na carreira literária ainda na escola, com participação na revista Elo, criada com colegas do Colégio Sion (1927 - 1929), tendo escrito posteriormente para Boletim de Ariel, onde exerceu crítica literária até 1937, Revista do Brasil (1938 a 1943) e nas décadas seguintes no Correio da Manhã, do Rio de Janeiro, e no Suplemento Literário O Estado de S. Paulo. Seu trabalho começou a ser conhecido dois anos antes desta matéria na Esfera, quando publicou Machado de Assis (estudo crítico-biográfico). Segundo Pontes,

Ele foi resenhado ou comentado por críticos e intelectuais importantes, como Alceu Amoroso
Lima, Álvaro Lins, Manuel Bandeira, Monteiro Lobato, Augusto Frederico Schmidt, José
Lins do Rego, entre outros. Com essa biografia, Lúcia ganhou o "maior prêmio literário da
época, concedido pela Sociedade Felipe d Oliveira (PEREIRA,1988 apud PONTES,
2008:520).

A rede de colaboradoras representada na Esfera, também inclui textos ficcionais de autoras estrangeiras e artigos e críticas sobre a obra de mulheres nascidas na América Latina e Europa.

Com poesias colaboraram Gabriela Mistral, com a transcrição dos poemas Pan, Fuego e Mariposa em espanhol (acompanhando a crítica de Enrique Fabregat, sobre seu livro Tala, publicado naquele ano na Argentina e França) e as portuguesas Natalina Bastos e Irene Lisboa com Poema do Silêncio e Coisa de Mulher, respectivamente. Maria Raquel, também de Portugal, publicou o conto

${ }^{131}$ Grifo meu.

132 PEREIRA, L. M. Amanhecer. Rio de Janeiro: Companhia Editora Nacional, $1^{\text {a }}$ edição, 1938. 
Progresso e Irene publicou, além de Coisa de Mulher, um trecho da novela A Estefânia, publicada integralmente em 1940 com o nome Começa uma Vida ${ }^{133}$.

Gabriela Mistral foi poeta, escritora e diplomata. Já Havia estado no Brasil em 1937 e, entre 1939 e 1943, exerceu o cargo de cônsul geral do Chile no País, período em que conviveu com intelectuais e artistas, promovendo o intercâmbio cultural entre Chile e Brasil. Foi a primeira mulher latino americana a ganhar o Prêmio Nobel de literatura, em 1945. Apesar da legitimação conquistada com o prêmio e o alcance de sua obra poética durante sua vida, seus poemas são pouco lembrados nos dias de hoje e sua prosa é quase desconhecida.

No artigo, Fabregat discorre sobre sua trajetória:

En ella han sido siempre la que canta e la que enseña, la que sueña y revela, la poetisa, la maestra, la mujer. Muy joven aún, Gabriela Mistral era maestra de escuela em Chile. Luego fué a México, en la vieja patria azteca. Y alli, como em el Chile fundó escuelas para los hijos del índio e para los hijos del blanco, porque Gabriela conseva em su corazón un sentido racial que se nutre de todos los elementos de lo humano.

Natalina Moura Pereira Bastos publicou no primeiro número da Esfera Poema do silêncio. Havia sido companheira de Afonso de Castro Senda no Grupo Jovens Liras e foi professora e militante pela paz, pelos direitos das mulheres e contra o fascismo e o regime salazarista, o que a levou a ser duas vezes detida pela polícia, em 1935 e 1937. Nos anos 1940, foi sócia da Associação de Solidariedade Social dos Professores e participou no núcleo do Porto da Associação Feminina Portuguesa para a Paz, onde fez parte da direção eleita para o ano de 1943-1944.

Irene Lisboa é o nome verdadeiro de João Falco. Para se proteger do controle da censura salazarista e expressar livremente sua posição contrária ao regime autoritário, como muitos outros escritores e escritoras de esquerda utilizava em sua escrita literária este e mais dois pseudônimos: Manoel Soares e Maria Moira. Diplomada pela Escola Normal em 1932, fez estudos de psicologia e pedagogia na Suíça, França e Bélgica. Sua atividade como educadora levou-a ao cargo de Inspetora orientadora do ensino primário e infantil do Ministério da Educação, mas poucos anos depois, afastada por se opor ao regime salazarista, passou a se dedicar exclusivamente à literatura. Em 1938 já havia publicado dois livros de poemas: Um dia e outro dia - Diário de uma mulher (1936) e Outono havias de vir latente triste (1937).

Segundo Petra Kaderková:

${ }^{133}$ FALCO, João. Começa a Vida; editora Seara Nova; Lisboa; 1940. 
Embora tenha conhecido classe alta superior, raramente descreve a rica burguesia lisbonense. É igualmente evidente que não simpatizou com os empresários bem-sucedidos, autores famosos, diplomatas ou camada social onde se movimentavam. Quando estes protótipos aparecem nos seus contos, são satiricamente retratados como insensíveis, frios e indiferentes aos problemas das classes mais baixas. Ainda que as suas sátiras sejam brilhantes, a autora prefere escrever realisticamente sobre os pobres. Os seus personagens são principalmente mulheres: educadoras, criadas ou serventes. Ao contrário, os homens são apresentados como fracos ou explorados: barbeiros, funcionários ou empresários bancarroteados.

Irene Lisboa é hoje considerada um dos nomes mais importantes da literatura portuguesa do século XX.

No artigo Mentalidade Feminina Brasileira, Afonso de Castro Senda compara Sylvia à Maria Raquel:

A antiga redatora de Brasil Feminino é, por exemplo, no Brasil o que entre nós é Maria Raquel; ou seja: pessoa que ultrapassou aquela amorfa e oca sentimentalidade do ambiente médio, para com a solidez que dão uma cultura bem apreendida e uma mentalidade invulgar, perder o coquetismo balofo de menina de boa família.

Seu nome também consta como colaboradora no jornal Foz de Guadiana, no elenco de colaboradores da revista Sol Nascente e no semanário O Diabo, o que a inclui no rol das escritoras da primeira fase do neorrealismo português (DIAS, 2011). No conto Progresso, publicado na Esfera, Lau da Tojeira, menino nascido em uma pequena localidade do interior de Portugal, deficiente físico, conta em linguagem popular, seu sofrimento ao ficar conhecido como menino bento.

Foram objeto de críticas, artigos e reportagens a poetisa suíça radicada desde a infância na argentina falecida no mês anterior, Alfonsina Storni, em La Voz que no apago la muerte e Gabriela Mistral, em Tala: el nuevo libro de Gabriela Mistral, ambos por Enrique Fabregat. Outra chilena, Marta Brunet, é objeto da crítica transcrita da revista América, de Havana, Cuba, de autoria de Julieta Carrera; e Katherine Mansfield foi um dos temas de Érico Veríssimo.

Julieta era uma escritora conhecida e publicava artigos sobre feminismo nos periódicos Repertório Americano (Costa Rica) e Acción Feminina (Chile) entre outros latino americanos. Em 1934 publicou Sexo, Femenidad y Economía ${ }^{134}$, um livro que significou uma verdadeira revolução no pensamento político e feminista da época, utilizando, entre outros teóricos, La mujer nueva y la moral sexual, de Alexandra Kollontay (1930), A Origem da Família, da Propriedade Privada e do Estado,

\footnotetext{
${ }^{134}$ CARRERA. Julieta. Sexo, feminilidad e economya. La Habana: Hechos Sociales, 1934.
} 
de Friedrich Engels (1884), Uma teoria sexual e outros ensaios, de Sigmund Freud e Mi vida, de Isadora Duncan (1927). O livro teve uma tiragem de 1000 exemplares que se esgotaram rapidamente. Seu trabalho também caiu no esquecimento (VALDÉS, 2008).

A chilena Marta Brunet era filha de uma família abastada, tendo realizado seus primeiros estudos com professores particulares e aos catorze anos partido para a Europa, onde teve contato com a obra de autores modernos. Em 1923 publicou Montaña adentro, obra realista que descreve a vida cotidiana e costumes dos camponeses de sua cidade natal, causando escândalo entre as classes altas da sua comunidade. No ano seguinte mudou-se para a capital, onde escreveu contos que circularam em periódicos de Santiago e Buenos Aires. Em 1938 já gozava de prestígio: havia publicado na imprensa as novelas Don Florisondo (1926) e Bestia dañina (1926), o tratado de arte culinária La hermanita hormiga (1931) e Cuentos para Marisol (1938), além de trabalhar como diretora da Revista Família. Foi consulesa do Chile em Buenos Aires de 1943 a $1952^{135}$.

Mulheres que conseguiam participar de concursos, ganhar prêmios literários e adentrar no círculo literário eram na maioria provenientes das classes mais altas. Alfonsina Storni, argentina, foi uma exceção, veio de uma família humilde e criou um filho sozinha em Buenos Aires. Sua obra também vai além da crítica ao patriarcado e à luta pela igualdade entre os sexos no trabalho e na política: representa, como Gilka Machado no Brasil, a introdução do erotismo feminino na literatura argentina. Segundo Oliveira, "Na sua poesia fala abertamente do desejo carnal, do amor livre, gravidez, menopausa e inversão dos papeis usuais na conquista amorosa" (OLIVEIRA, 2009: 5). A partir do ano 2000 foram publicadas várias biografias suas, entre elas La otra Alfonsina (2002), por Ana Silvia Galán e Graciela Gliemmo e Mi casa es mi mar (2003), de Tânia Pleitez. "O que todas as críticas têm em comum é o reconhecimento da importância de Alfonsina Storni dentro da literatura argentina e a afirmação de ser necessário um estudo mais aprofundado sobre sua obra" (idem, 2009: 42).

Segundo Catá, que escreveu o artigo sob a emoção de seu suicídio ocorrido no mês anterior ao da publicação:

De muy sugestivos detalles esta formada la vida de la poetisa argentina ahora desaparecida. Alfonsina Storni comenzó su vida de labor e lucha como Professora de la escuela primaria. Igual que la chilena maxima Gabriela Mistral. Igual que la uruguaiana Luisa Luisi, nunca bastante alabada. Igual que Almafuerte, poeta e profeta. Son estos talvez sus hermanos liricos

\footnotetext{
${ }^{135}$ Biografia de Marta Brunet. Universidad del Chile. Disponível em: <http://www.uchile.cl/portal/extension-ycultura/vicerrectoria-de-extension-y-comunicaciones/patrimonio-cultural-marta-brunet/83830/biografia>. Acesso em $19 / 02 / 2019$.
} 
em aquella misma latitud continental donde están los Andes, donde esta la Pampa, donde se ensancha y crece hacia las libertades oceanicas y las libertades historicas y sociales, la llanura azul del Gran Rio.

Katherine Mansfield era o nome artístico de Kathleen Mansfield Beauchamp, (depois de casada passou a adotar o sobrenome Murry). Nasceu em Nova Zelândia, filha de uma família de posses. Na primeira década do século XX, morou em Londres, onde participava da vida boêmia da cidade, publicava seus trabalhos e críticas literárias na imprensa inglesa e sua obra era conhecida: Virginia Wolf chegou a declarar que Mansfield era a única escritora que lhe fazia inveja pela qualidade de seu trabalho. Hoje ela é uma autora consagrada como uma das mais importantes contistas modernistas da língua inglesa. A Esfera publicou seu conto Feuille D'Album, traduzido por Érico Veríssimo, que foi o responsável pela primeira tradução de sua obra para o português, o livro Bliss-Felicidade, editado pela Livraria do Globo em 1940. Em 1937, Vinicius de Moraes lhe dedicou o Soneto a Katherine Mansfield.

Com artigos sobre temas científicos colaboraram Maria Violeta Coutinho (Villas Boas), Jeanette Budin, Iva Weisberg e a portuguesa Adelaide Estrada.

As três brasileiras são da mesma geração, tinham 25 anos, foram colegas na Escola Normal e fizeram curso superior, onde participaram do movimento estudantil. Maria Violeta e Jeanette publicaram artigos sobre folclore, a primeira escreveu O Folk Negro no Brasil e a segunda publicou a adaptação e tradução da lenda hindu Mais Poderoso que a Morte, onde anuncia seu livro O Amor no Folclore. Iva escreveu sobre a organização internacional do trabalho. Temas que não se vinculam diretamente com a carreira que seguiram com sucesso no futuro, a educação.

Iva Weisberg formou-se em Sociologia na Universidade do Distrito Federal e "firmou-se como intelectual de uma geração que desafiou a política educacional autoritária do primeiro governo Vargas (1930 - 1945)" (LOPES, 2017: 12). Quando colaborou com a Esfera ainda era estudante e participava da política estudantil: foi membro da União Universitária Feminina, instituição que representou no II Congresso Nacional dos Estudantes realizado no Rio de Janeiro naquele ano e da comissão organizadora da Conferência Pan Americana de Estudantes, promovida pela Casa do Estudante no ano seguinte (VIDAL, 2019). Jeanette Budin cursou Letras na Escola da Filosofia da Universidade do Distrito Federal. Era recém-formada: diplomou-se um ano antes, em 1937. Foi professora de português catedrática do Instituto de Educação do Distrito Federal, dedicou-se à educação e é lembrada pela autoria do manual de ensino Metodologia da Linguagem: para uso das Escolas Normais e Institutos de Educação (1949). Morreu cedo, aos 39 anos (SALES, 2011). 
Maria Violeta foi diretora do Instituto de Educação do Rio de Janeiro na década de 1940, é autora dos livros Psicologia educacional e Como Estudar (1959), da série Formação de técnicos do Serviço Nacional de Aprendizagem Comercial (SENAC) e Educação: Reflexões Sobre uma Prática, publicado pela UERJ em 1998.

Adelaide Estrada, tinha 38 anos de idade e atuava há doze anos como médica, fato raro entre as mulheres portuguesas no início do século XX. Em 1920, quando ingressou na Faculdade do Porto, haviam apenas sete mulheres em uma turma de sessenta alunos do primeiro ano e, seis anos depois quando se formou, foi a única mulher entre os quarenta e quatro formandos ${ }^{136}$. Discípula de Abel Salazar, foi sua companheira de trabalho na Universidade do Porto e colaborou com artigos científicos nas revistas neorrealistas Pensamento e $O$ Sol Nascente, além de publicar em diferentes veículos da imprensa portuguesa e estrangeira.

\subsection{0 - Índices e propagandas da revista Esfera}

Comentei na introdução que a opção escolhida para o desenvolvimento desta dissertação implicou em abrir mão de vários outros aspectos que aparecem no decorrer da pesquisa. Os quadros abaixo fazem parte deste processo e podem, eventualmente, se tornar no futuro objetos ou fontes para novas pesquisas.

Figura 41 - Tabela 2 - ÍNDICE, REVISTA ESFERA, DE LETRAS, ARTES E CIÊNCIAS, RIO DE JANEIRO, 1938 - 1950

\begin{tabular}{|l|l|l|l|}
\hline Núm. & Pág. & Título & Autor \\
\hline 1 & 5 & Rosas Vermelhas & Rubem Braga \\
\hline 1 & 6 & Depoimento & Marques Rebelo \\
\hline 1 & 7 & Um Anúncio & Graciliano Ramos \\
\hline 1 & 8 & Trecho do discurso acadêmico & Santa Rosa \\
\hline 1 & 10 & Ulustração gênio & Carlos Cruz \\
\hline 1 & 11 & Regresso & Dias da Costa \\
\hline 1 & 13 & Nota sobre A Estrada Real & Frederico Reys Coutinho \\
\hline 1 & 15 & Volta & Jorge Amado \\
\hline 1 & 16 & O Poeta & Phócion Serpa \\
\hline 1 & 17 & Olhai os Lírios do Campo & Érico Veríssimo \\
\hline 1 & 19 & $\begin{array}{l}\text { Algumas Reflexões despropositadas sobre certos } \\
\text { despropósitos }\end{array}$ & Afonso de Castro Senda \\
\hline 1 & 21 & Formas & Afonso Schmidt \\
\hline 1 & 21 & Ilustração & Paulo Werneck \\
\hline 1 & 22 & De Charles Louis Phillipe & Charles Louis Philippe \\
\hline 1 & 23 & Jorge Amado, Romântico & Benjamim Lima \\
\hline 1 & 24 & Maria Violeta Coutinho & O Folk Negro no Brasil \\
\hline 1 & 25 & Mulher do Povo & Abel Salazar \\
\hline
\end{tabular}

${ }^{136}$ ANUÁRIO da Faculdade de Medicina do Porto, XIV volume, Emp. Ind. Gráfica do Porto, 1928. 


\begin{tabular}{|c|c|c|c|}
\hline 1 & 26 & O amor no Folk-lore & Jeanette Budim \\
\hline 1 & 27 & Vidas Secas & Eneida \\
\hline 1 & 28 & Eu Morri para o Mundo & Joel da Silveira \\
\hline 1 & 31 & Poema para a meninasinha de ouro & Henriqueta Lisboa \\
\hline 1 & 32 & Sabiá & Sylvia de Leon Chalreo \\
\hline 1 & 33 & A Formação do Mundo Moderno & Fábio Crissiúma \\
\hline 1 & 36 & Cartas aos meus Filhos & Roberto Alvim Corrêa \\
\hline 1 & 37 & A Terceira Dimensão no Romance Brasileiro & Maria Jacintha \\
\hline 1 & 39 & Sobre literatura Ibero-Americana & Atílio Garcia Mellid \\
\hline 1 & 40 & Quadros Rústicos & Heitor Lúcio \\
\hline 1 & 41 & A Velha Casa & José Régio \\
\hline 1 & 49 & O meu Amor vai para o teu devagarinho & Cleómenes Campos de Oliveira \\
\hline 1 & 49 & Balada do mês de Dezembro & Theoderick de Almeida \\
\hline 1 & 50 & Poema do Silêncio & Natalina Bastos \\
\hline 1 & 51 & As várias Facetas da Verdade & Abel Salazar \\
\hline 1 & 53 & Canção de Solveig & Luiz de Sanjusto \\
\hline 1 & 55 & Interpretando Jubiabá & Gerardo Reys \\
\hline 1 & 57 & Planos de cidade & Washington Azevedo \\
\hline 1 & 59 & Medicina, fator de civilização & Fabio Leite Lobo \\
\hline 1 & 61 & Revolução & Abelardo Romero \\
\hline 1 & 65 & $\begin{array}{l}\text { Panorama Cultural Português - Mensagem que preambula } \\
\text { um edifício cuja construção começa desde já }\end{array}$ & Afonso de Castro Senda \\
\hline 1 & 67 & A Marquesa de Santos & E. (Eneida?) \\
\hline 1 & 68 & O homem que nasceu duas vezes & E. (Eneida?) \\
\hline 1 & 69 & Emile Zola & E. (Eneida?) \\
\hline 1 & 70 & Felicidade Mentira & E. (Eneida?) \\
\hline 1 & 70 & Madame Waleska & E. (Eneida?) \\
\hline 1 & 70 & No teatro da vida & E. (Eneida?) \\
\hline 1 & 70 & Rainha Vitória & E. (Eneida?) \\
\hline 1 & 71 & Rádio & S. (Sylvia de Leon Chalreo) \\
\hline 2 & 3 & Hai-Kai & Manuel Bandeira \\
\hline 2 & 4 & Outono as Folhas caem & Álvaro Moreyra \\
\hline 2 & 6 & Carta a um jovem colega & Amadeu Amaral Junior \\
\hline 2 & 7 & O folk-lore cristão do Brasil & Arthur Ramos \\
\hline 2 & 9 & O cotovelo dói & Carlos Drummond de Andrade \\
\hline 2 & 10 & Partido Trabalhista da Escócia & Editoria \\
\hline 2 & 11 & Esquisso & Abel Salazar \\
\hline 2 & 12 & Revelação de Essência & Afonso de Castro Senda \\
\hline 2 & 12 & Ilustração & Santa Rosa \\
\hline 2 & 13 & Razão de ser e de viver & Afonso de Castro Senda \\
\hline 2 & 13 & Ilustração & Santa Rosa \\
\hline 2 & 14 & Guerra? & Editoria \\
\hline 2 & 15 & Pedaço de Caminho & Joel da Silveira \\
\hline 2 & 16 & Delícia de Viver & Pedro Paulo \\
\hline 2 & 17 & Mozart & José Lins do Rego \\
\hline 2 & 18 & A revolução científica e filosofia do século XX & Abel Salazar \\
\hline 2 & 21 & Retrato do Pintor Leopoldo Mendez & Jorge Amado \\
\hline 2 & 22 & Ilustração & Leopoldo Mendez \\
\hline 2 & 23 & A América do Norte e o pacto Briand-Kellog & Editoria \\
\hline 2 & 24 & Festinhas & Sangirardi Junior \\
\hline
\end{tabular}




\begin{tabular}{|c|c|c|c|}
\hline 2 & 25 & Similitud & Miguel Bustos Cerecedo \\
\hline 2 & 25 & Canción & Nicolas Guillen \\
\hline 2 & 26 & Poesia e Realidade & Jacques Madaule \\
\hline 2 & 27 & Ler velhas cartas e depois chorar & Osorio Borba \\
\hline 2 & 28 & A Natureza, o Homem e a Cultura no Brasil & Editoria \\
\hline 2 & 29 & Orações Milagrosas & Edison Carneiro \\
\hline 2 & 31 & Poema da hora que passa & Nilo da Silveira Werneck \\
\hline 2 & 31 & Ilustração & Paulo Werneck \\
\hline 2 & 32 & Poema de Maio & Aydano do Couto Ferraz \\
\hline 2 & 32 & Exaltação & Ivani Ribeiro \\
\hline 2 & 32 & Jesus Errante & Julieta Bárbara \\
\hline 2 & 33 & Suicídio de Lindaura & Oswald de Andrade \\
\hline 2 & 34 & Profissão de fé de um poeta pagão & Luiz de Sanjusto \\
\hline 2 & 35 & Ermeto Zarcconi & José Maria Monner Sans \\
\hline 2 & 37 & Paisagem do Paraná & Vicente Leite \\
\hline 2 & 38 & A experiência da adolescência em Gorki & D'Almeida Vitor \\
\hline 2 & 41 & Regime de maus tratos & Ademar Vidal \\
\hline 2 & 43 & Natureza Morta & Emil Fila \\
\hline 2 & 43 & Flavio de Carvalho entrevista o pintor Tcheco Emil Fila & Flávio de Carvalho \\
\hline 2 & 44 & A Emoção na Exposição de Arte Francesa & Sylvia de Leon Chalreo \\
\hline 2 & 45 & Pedra Bonita & Dias da Costa \\
\hline 2 & 46 & Sem título & Érico Veríssimo \\
\hline 2 & 47 & Reportagem em um Prólogo, Vários atos e um Epílogo & Sady Garibaldi \\
\hline 2 & 49 & Trecho de Romance & José Geraldo Vieira \\
\hline 2 & 51 & Carta sobre Artes Plásticas no Salão de Maio & Geraldo Ferraz \\
\hline 2 & 52 & A Liquidação do caso Etíope & Editoria \\
\hline 2 & 52 & Duração de guerra da Hespanha & Editoria \\
\hline 2 & 53 & O Lobo e a Ovelha & Waldemar de Oliveira \\
\hline 2 & 54 & Roma Berlim & Editoria \\
\hline 2 & 55 & Organização Internacional do Trabalho & Iva Weisberg \\
\hline 2 & 57 & Terra - poema de Mario Donato & Afonso Schmidt \\
\hline 2 & 58 & Ana Amélia e A harmonia das coisas e dos seres & Maria Jacintha \\
\hline 2 & 61 & Uma página de Jean Guéhenno & \\
\hline 2 & 63 & El nuevo Pensamiento Argentino & Garcia Mellid \\
\hline 2 & 65 & Vida Artística & Editoria \\
\hline 2 & 66 & A Inglaterra armazena para a guerra & Editoria \\
\hline 2 & 67 & O renascimento na China & Editoria \\
\hline 2 & 67 & A Formação do Mundo Moderno & Fábio Crissiúma \\
\hline 2 & 69 & A Margem da Primeira Semana Regional de Tuberculose & Fabio Leite Lobo \\
\hline 2 & 71 & Nota resenha sobre a redemocratização em Portugal & sem autoria \\
\hline 2 & 74 & Livros e Revistas & F. \\
\hline 2 & 75 & Baile de Máscaras & Editoria \\
\hline 2 & 76 & Cinema & Editoria \\
\hline 2 & 76 & Fontes Luminosas & Editoria \\
\hline 2 & 77 & Comentando Rádio & S. (Sylvia de Leon Chalreo) \\
\hline 3 & 7 & Ilustração & Oswald de Andrade Filho (Nonê) \\
\hline 3 & 7 & Escutai meu aniquilamento & Rossine Camargo Guarnieri \\
\hline 3 & 8 & Palavras em que se Fala de Jean Guéhenno & Afonso de Castro Senda \\
\hline 3 & 11 & Os devaneios do General & Érico Veríssimo \\
\hline 3 & 14 & Hai Kais & Alvaro Yunque \\
\hline
\end{tabular}




\begin{tabular}{|c|c|c|c|}
\hline 3 & 15 & A Noite dissolve os Homens & Carlos Drummond de Andrade \\
\hline 3 & 16 & Roman Rolland & Frans Masereel \\
\hline 3 & 18 & $\begin{array}{l}\text { Esquema para um ensaio sobre a arte como criação livre e } \\
\text { inalienável }\end{array}$ & Adolfo Casais Monteiro \\
\hline 3 & 21 & Clarina, a que morreu & Joel da Silveira \\
\hline 3 & 23 & A poesia está viva & Álvaro Moreyra \\
\hline 3 & 25 & Hristo Botjov & Kliment I V Kostov \\
\hline 3 & 26 & Coelho Neto pisou sobre tesouros & Emil Farhat \\
\hline 3 & 27 & Um homem entre frases & Eneida \\
\hline 3 & 28 & Nós acendemos as nossas estrelas & José Sampaio - \\
\hline 3 & 29 & Irmãos, meus irmãos & Henriqueta Lisboa \\
\hline 3 & 30 & O sentido nacionalista da obra de Carlos Gomes & Waldemar de Oliveira \\
\hline 3 & 32 & Fundamentos Econômicos da literatura brasileira & Peregrino Junior \\
\hline 3 & 33 & O caso Rachel de Queiroz & J. A. Seabra de Melo \\
\hline 3 & 34 & Porto Inseguro & Odilon Negrão \\
\hline 3 & 35 & O que deu para dar-se natureza & Edison Carneiro \\
\hline 3 & 36 & A Candeia & Lygia (Fagundes Telles?) \\
\hline 3 & 36 & O Caminho das Estrelas & Mario Dionísio \\
\hline 3 & 37 & O mundo nascera-me outra vez & Antônio Gameiro \\
\hline 3 & 37 & Saudade & Manuel da Fonseca \\
\hline 3 & 38 & Resposta a Jacques Poisson & Nilo da Silveira Werneck \\
\hline 3 & 39 & Praia de Olinda & Luís Soares \\
\hline 3 & 40 & de Juventude Morta & Medeiros Lima \\
\hline 3 & 42 & Olhai os Lírios do Campo & Dias da Costa \\
\hline 3 & 44 & Paris em 1934 & Dias da Costa \\
\hline 3 & 45 & Tres Momentos de Uma estrada que sobe & Maria Jacintha \\
\hline 3 & 49 & Revelação de Zola & Walter da Silveira \\
\hline 3 & 51 & a formação do mundo moderno & Fábio Crissiúma \\
\hline 3 & 52 & Uma Exposição & Sylvia de Leon Chalreo \\
\hline 3 & 53 & Prisão & Abelardo Romero \\
\hline 3 & 54 & O destino de nosso Amor & D'Almeida Vitor \\
\hline 3 & 55 & Matei um Homem & Abguar Bastos \\
\hline 3 & 57 & O Movimento Teatral em Londres & Editoria \\
\hline 3 & 58 & Os Azevedos do Poço & Mário Sette \\
\hline 3 & 61 & A revolução científica e filosófica do século XX & Abel Salazar \\
\hline 3 & 63 & Pela Cultura do Povo & Editoria \\
\hline 3 & 64 & Cartas & Paschoal Carlos Magno \\
\hline 3 & 65 & Letras de Hispano America & E. Rodrigues Fabregat \\
\hline 3 & 67 & $\begin{array}{l}\text { Documentário Cultural Português - Nota-resenha sobre a } \\
\text { democratização em Portugal }\end{array}$ & Afonso de Castro Senda \\
\hline 3 & 69 & Livros & Editoria \\
\hline 3 & 71 & Zazá, Dulcina Odilon e outros comentários & M. \\
\hline 3 & 73 & Cinema & E. (Eneida?) \\
\hline 3 & 74 & Comentando Rádio & S. (Sylvia de Leon Chalreo) \\
\hline 4 & 5 & Do diário de um anônimo & Dias da Costa \\
\hline 4 & 6 & Crônica um pouco leve & Joel da Silveira \\
\hline 4 & 7 & A caminho do Rio Doce & Anna Amélia Carneiro de Mendonça \\
\hline 4 & 8 & Olhai o Érico Veríssimo & Miroel Silveira \\
\hline 4 & 9 & La Moneda Ideal & Alfonso Hernandez Catá \\
\hline 4 & 11 & Santa Missão & Joaquim Maciel Filho \\
\hline 4 & 12 & Necessidade e Beleza & Joaquim Ribeiro \\
\hline
\end{tabular}




\begin{tabular}{|c|c|c|c|}
\hline 4 & 13 & Millet e Graciliano Ramos & Abel Salazar \\
\hline 4 & 14 & Ilustração & Percy Lau \\
\hline 4 & 18 & El despertar de la autenticidad nativa & Atilio Garcia Mellid \\
\hline 4 & 19 & Mês Mariano & Mário Sette \\
\hline 4 & 20 & Estrela do Mar & Rossine Camargo Guarnieri \\
\hline 4 & 22 & O Gosto da Vida & Maria Jacintha \\
\hline 4 & 26 & Pleniluneo & Gerardo Reys \\
\hline 4 & 27 & Desenho & Abel Salazar \\
\hline 4 & 28 & $\begin{array}{l}\text { Acerca dos conhecimentos indispensáveis ao escritor de } \\
\text { Belas Artes }\end{array}$ & João Alberto \\
\hline 4 & 30 & Manuel Campelo & Lucillo Varejão \\
\hline 4 & 31 & $\begin{array}{l}\text { Apontamento sobre indivíduo, coletividade e outras } \\
\text { coisas }\end{array}$ & Afonso de Castro Senda \\
\hline 4 & 33 & Luiz Agassiz e o Brasil & Odilon Negrão \\
\hline 4 & 35 & A B C de João e Maria & Álvaro Moreyra \\
\hline 4 & 36 & Procissão & Nelio Reis \\
\hline 4 & 37 & Einstein & Abel Salazar \\
\hline 4 & 37 & A noção de Tempo & Ruy Luiz Gomes \\
\hline 4 & 39 & Gilda Moreira & Sylvia de Leon Chalreo \\
\hline 4 & 40 & A fala soturna do grande desterrado & Nilo da Silveira Werneck \\
\hline 4 & 40 & Ilustração & Paulo Werneck \\
\hline 4 & 41 & Progresso & Maria Raquel \\
\hline 4 & 43 & Coisa de Mulher & João Falco / Irene Lisboa \\
\hline 4 & 44 & Xarqueada & Maura de Senna Pereira \\
\hline 4 & 46 & Notas rápidas sobre a vida de um par & Diniz Cupertino \\
\hline 4 & 47 & O Romance Brasileiro & Dias da Costa \\
\hline 4 & 49 & A Formação do Mundo Moderno & Fabio Crissiuma \\
\hline 4 & 51 & História de passar & Antônio Dias Tavares Bastos \\
\hline 4 & 52 & Lembrança de uma página de diário & Medeiros Lima \\
\hline 4 & 54 & Desenho & Percy Lau \\
\hline 4 & 56 & Visão & Wilson Rodrigues \\
\hline 4 & 57 & Na gleba amargurada de Raul Leoni & Danilo Bastos \\
\hline 4 & 59 & Dois Poetas Paulistas & Aydano do Couto Ferraz \\
\hline 4 & 61 & $\begin{array}{l}\text { Harald Höffding - "Personalité" in "Concepcion de la vie" } \\
\text { - Felix Alcan - Paris }\end{array}$ & Afonso de Castro Senda \\
\hline 4 & 62 & Tala: el nuevo libro de Gabriela Mistral & Enrique Rodrigues Fabregat \\
\hline 4 & 62 & Mariposa & Gabriela Mistral \\
\hline 4 & 63 & Fuego & Gabriela Mistral \\
\hline 4 & 63 & Pan & Gabriela Mistral \\
\hline 4 & 64 & $\begin{array}{l}\text { Nota sobre a redemocratização em Portugal. Esfera e o } \\
\text { intercambio luso brasileiro }\end{array}$ & Editoria \\
\hline 4 & 66 & Livros & Editoria \\
\hline 4 & 69 & Jornais e Revistas & Editoria \\
\hline 4 & 71 & Teatro - Fora da Vida & Editoria \\
\hline 4 & 72 & Cinema & E. (Eneida?) \\
\hline 4 & 73 & Comentando Rádio & S. (Sylvia de Leon Chalreo) \\
\hline 5 & 5 & El Genio del Pueblo Espanhol & Manuel Garcia Miranda \\
\hline 5 & 7 & Mocambos do Recife & Gilka Machado \\
\hline 5 & 7 & Ilustração & Percy Lau \\
\hline 5 & 8 & A minha vida é um romance & Abelardo Romero \\
\hline 5 & 9 & Conto muito feliz & Joel da Silveira \\
\hline
\end{tabular}




\begin{tabular}{|c|c|c|c|}
\hline 5 & 11 & Gorki e seus personagens & Jarbas Andrea \\
\hline 5 & 12 & Fiestas em Mexico & Maria da Gloria de Almeida Portugal \\
\hline 5 & 13 & Words... Words... words... & Antônio Joaquim Pereira da Silva \\
\hline 5 & 14 & Um Conteur & Oswaldino Ribeiro Marques \\
\hline 5 & 15 & A Floresta & Raymundo Moraes \\
\hline 5 & 19 & Como se faz literatura infantil em Portugal & Vinha dos Santos \\
\hline 5 & 21 & Desenho & Abel Salazar \\
\hline 5 & 22 & Feuille D'Album & Katherine Mansfield \\
\hline 5 & 25 & $\begin{array}{l}\text { Ensaio de uma história comparada dos povos da Europa } \\
\text { de Seignobos }\end{array}$ & Afonso de Castro Senda \\
\hline 5 & 27 & Os pássaros voam & Toledo Arruda \\
\hline 5 & 28 & Palavras sobre a missão utilitária do artista & Kliment I V Kostov \\
\hline 5 & 29 & O senhor Deus & Ligia de Azevedo Fagundes \\
\hline 5 & 30 & $\begin{array}{l}\text { Aspectos do aniquilamento da vontade humana na } \\
\text { literatura }\end{array}$ & José Santa Rita \\
\hline 5 & 31 & Eu tenho uma inveja imensa... & Cleómenes Campos de Oliveira \\
\hline 5 & 32 & Erico Verissimo e os problemas do mundo & Barreto de Araújo \\
\hline 5 & 33 & O tradutor e a crítica & Antônio Barata \\
\hline 5 & 34 & Paulista Prado Pintor Pioneiro & Geraldo Ferraz \\
\hline 5 & 35 & A lição do Mar & Alves Ribeiro \\
\hline 5 & 36 & As maleitas - sezonismo & Adelaide Estrada \\
\hline 5 & 39 & Eça de Queiroz e o século XIX & Dias da Costa \\
\hline 5 & 40 & Círculo de Interpenetração Panamericana & Editoria \\
\hline 5 & 41 & Hai Kais & Augusto Pinho \\
\hline 5 & 42 & Hai Kais & Mario Soto Maior \\
\hline 5 & 43 & Das "Memórias" de Alberto & Paulo Crato \\
\hline 5 & 44 & O último livro de Galeão Coutinho & Paulo Cavalcanti \\
\hline 5 & 45 & Coimbra & D'Almeida Vitor \\
\hline 5 & 46 & Obras de artes salvadas pelos republicanos espanhóis & sem autoria \\
\hline 5 & 47 & O falecido Maneca Araújo & Souza Junior \\
\hline 5 & 49 & Exortação & Nilo da Silveira Werneck \\
\hline 5 & 50 & Aluísio Medeiros - o poeta esponja & Rui de Carvalho \\
\hline 5 & 52 & A Formação do Mundo Moderno & Fabio Crissiuma \\
\hline 5 & 53 & Masdekismo e Osirismo & Abel Salazar \\
\hline 5 & 56 & Um grande pintor pernambucano & Sergio Soares \\
\hline 5 & 57 & O poeta emigrou & Fernando Góes \\
\hline 5 & 59 & Vidas Secas, romance direto & Tulio Hostilio Montenegro \\
\hline 5 & 60 & Palavras de despedida & Walter da Silveira \\
\hline 5 & 61 & $\begin{array}{l}\text { A Checoslovaquia e a Alemanha, a Democracia e o } \\
\text { Fascismo }\end{array}$ & Paulo Zingg \\
\hline 5 & 63 & El cinquentenario de Sarmiento & Enrique Rodrigues Fabregat \\
\hline 5 & 65 & Documentário Cultural Português & Afonso de Castro Senda \\
\hline 5 & 67 & Um problema de três séculos & sem autoria \\
\hline 5 & 68 & Livros & Editoria \\
\hline 5 & 69 & Jornais e Revistas & Editoria \\
\hline 5 & 70 & Cinema & sem autoria \\
\hline 5 & 71 & Teatro & Maria Jacintha \\
\hline 5 & 72 & Comentando Rádio & S. (Sylvia de Leon Chalreo) \\
\hline 6 & 5 & Rex & Álvaro Moreyra \\
\hline 6 & 6 & Sombra & João de Barros \\
\hline 6 & 7 & Mar Grande & Dias da Costa \\
\hline
\end{tabular}




\begin{tabular}{|c|c|c|c|}
\hline 6 & 10 & À meia noite, em outubro, ao sudoeste & Jorge de Lima \\
\hline 6 & 11 & O homem perfeito e feliz & Thomas Murat \\
\hline 6 & 13 & João Plácido & Joel da Silveira \\
\hline 6 & 15 & Tagore e Gorki & Nélo \\
\hline 6 & 16 & Puck ainda faz das suas... & Telmo Vergara \\
\hline 6 & 17 & Marinha & Antônio de Pádua \\
\hline 6 & 18 & Função Estética do Ritmo & Roberto Nobre \\
\hline 6 & 20 & Senhor, eu te deixei & Rossine Camargo Guarnieri \\
\hline 6 & 21 & Poesia Negra & Rui de Carvalho \\
\hline 6 & 22 & Humanidade & Mario Donato \\
\hline 6 & 23 & Estes homens educados na Inglaterra & Miroel Silveira \\
\hline 6 & 25 & Arte Poética & Mario Dionísio \\
\hline 6 & 26 & Rossine Camargo Guarnieri & Abelardo Romero \\
\hline 6 & 27 & Legenda Bíblica & Theoderick de Almeida \\
\hline 6 & 28 & As sete partidas do mundo & Fernando Namora \\
\hline 6 & 29 & A Universidade em "Eça de Queiroz" & Clovis G. Costa \\
\hline 6 & 30 & Então fiscalizem as Marias & Emil Farhat \\
\hline 6 & 31 & Templos e monumentos do México & sem autoria \\
\hline 6 & 32 & A solução do problema do Ferro & Nilo da Silveira Werneck \\
\hline 6 & 33 & O dono da Terra & Judas Isgorogota \\
\hline 6 & 34 & De "Miramar" & Sylvia de Leon Chalreo \\
\hline 6 & 35 & A Túnica inconsútil & Dias da Costa \\
\hline 6 & 37 & Martim Pescador & Edison Carneiro \\
\hline 6 & 38 & A poesia de Adalgisa Nery & Álvaro Lins \\
\hline 6 & 39 & Fim de linha & Firmino Magalhães \\
\hline 6 & 40 & Juventude e Eternidade & Jorge Domingues \\
\hline 6 & 43 & Henriqueta Lisboa e Velário & Maria Jacintha \\
\hline 6 & 45 & Meditação Pacifista & Helio Peixoto \\
\hline 6 & 46 & Brincando de viajar & Antônio Dias Tavares Bastos \\
\hline 6 & 47 & Luís Soares Visto por Moá & Moá \\
\hline 6 & 48 & Masdekismo e Osirismo & Abel Salazar \\
\hline 6 & 54 & Um rapaz sexagenário & Amadeu de Queiroz \\
\hline 6 & 56 & Rumo & Arlindo del Picchia \\
\hline 6 & 57 & Por cima das fronteiras de Todamérica & Remy Fonseca \\
\hline 6 & 58 & $\begin{array}{l}\text { A inquietação humana contemporanea na moderna poesia } \\
\text { portuguesa }\end{array}$ & Manuel Anselmo \\
\hline 6 & 60 & Rumos do romance brasileiro & Newton Freitas \\
\hline 6 & 62 & $\begin{array}{l}\text { A Checoslovaquia e a Alemanha, a Democracia e o } \\
\text { Fascismo }\end{array}$ & Paulo Zingg \\
\hline 6 & 64 & Nuevos Libros Americanos & Enrique Rodrigues Fabregat \\
\hline 6 & 66 & Cinema & sem autoria \\
\hline 6 & 66 & Artes Plásticas & sem autoria \\
\hline 6 & 66 & A Igreja e a Questão Racista & sem autoria \\
\hline 6 & 66 & Sobre o nosso Sentido e Projeção & sem autoria \\
\hline 6 & 66 & Revista da Imprensa & sem autoria \\
\hline 6 & 66 & Apêndice & sem autoria \\
\hline 6 & 69 & Livros & sem autoria \\
\hline 6 & 71 & Jornais e Revistas & sem autoria \\
\hline 6 & 72 & Teatro & J. M. \\
\hline 6 & 74 & Rádio - Morte de Luís Barbosa & S. (Sylvia) \\
\hline 6 & 74 & Cinema & sem autoria \\
\hline
\end{tabular}




\begin{tabular}{|c|c|c|c|}
\hline 7 & 5 & Era uma vez uma menina sádica & Jorge de Lima \\
\hline 7 & 6 & Do peso dos ídolos na evolução histórica & Carlos Relvas \\
\hline 7 & 7 & Na doce paz da noite um velho chora & Rossine Camargo Guarnieri \\
\hline 7 & 11 & Depoimento Pessoal & Edison Carneiro \\
\hline 7 & 13 & Quatro ideias e quatro pontos cardiais & Rui de Carvalho \\
\hline 7 & 14 & Strauss, cerveja e sonho & Athos Damasceno \\
\hline 7 & 15 & Hai Kais & Álvaro Yunque \\
\hline 7 & 16 & Como um Velho Tapete & Abelardo Romero \\
\hline 7 & 17 & O poeta repousará durante sete séculos & Deolindo Tavares \\
\hline 7 & 18 & Madame Curie & Edgard Cavalheiro \\
\hline 7 & 19 & 9 Histórias tranquilas & Maria Jacintha \\
\hline 7 & 22 & Trem Perdido & Mário Sette \\
\hline 7 & 24 & Partir & Tomaz Kim \\
\hline 7 & 25 & O Cortiço & Augusto Pinho \\
\hline 7 & 25 & O Cortiço & Murilo Mendes \\
\hline 7 & 26 & A Estefânia & João Falco / Irene Lisboa \\
\hline 7 & 29 & Desenho & Abel Salazar \\
\hline 7 & 30 & Negro Fugido & Reginaldo Guimarães \\
\hline 7 & 31 & Poema de Mayo & Aydano do Couto Ferraz \\
\hline 7 & 32 & Treze anos & Hamilcar de Garcia \\
\hline 7 & 33 & A feira na avenida Tiradentes & Cleómenes Campos de Oliveira \\
\hline 7 & 34 & Amanhecer & Dias da Costa \\
\hline 7 & 37 & Itinerário & Joel da Silveira \\
\hline 7 & 38 & Círculo vicioso & J. M. de Carvalho Junior \\
\hline 7 & 39 & A Vila & Omer Mont'Alegre \\
\hline 7 & 40 & Tédio & Elisa Lispector \\
\hline 7 & 41 & A nova poesia de Gilka Machado & Sylvia \\
\hline 7 & 43 & Descoberta do caminho impossível & Afonso de Castro Senda \\
\hline 7 & 44 & Mais além do racional & Afonso de Castro Senda \\
\hline 7 & 45 & Linha quebrada & Afonso de Castro Senda \\
\hline 7 & 46 & Da página sessenta & Emil Farhat \\
\hline 7 & 47 & Literatura e Ciência & Mario Barata \\
\hline 7 & 48 & Mazdekismo e Osirismo & Abel Salazar \\
\hline 7 & 48 & S. Paulo Pictórcio & Souza Filho \\
\hline 7 & 49 & Paisagem & Celso Augusto \\
\hline 7 & 51 & Notas do Editor & Editoria \\
\hline 7 & 52 & Acalanto do Menino & Nair Batista \\
\hline 7 & 53 & A gaivota e a Tartaruga & Raimundo Morais \\
\hline 7 & 54 & Luz & Paulo Correa Lopes \\
\hline 7 & 55 & Dominguez Alvarez & João Alberto \\
\hline 7 & 57 & Esse Jorge de Lima & Nilo da Silveira Werneck \\
\hline 7 & 58 & A Moacyr de Almeida & Heitor Lúcio \\
\hline 7 & 59 & Percy Lau & R. de C. \\
\hline 7 & 60 & La voz que no apago la muerte & Enrique Rodrigues Fabregat \\
\hline 7 & 62 & Terra Amarga & S. (Sylvia) \\
\hline 7 & 63 & Documentário Cultural Português & Afonso de Castro Senda \\
\hline 7 & 66 & Literatura & Editoria \\
\hline 7 & 67 & Jornais e Revistas & sem autoria \\
\hline 7 & 69 & Teatro - Yayá Boneca e outros & Maria Jacintha \\
\hline 7 & 73 & Cinema & sem autoria \\
\hline
\end{tabular}




\begin{tabular}{|c|c|c|c|}
\hline 7 & 74 & Rádio & Editoria \\
\hline 8 & 5 & Amanhã & Manuel da Fonseca \\
\hline 8 & 6 & Noite de Caes & Jorge Amado \\
\hline 8 & 9 & Chinês & Carlos Scliar \\
\hline 8 & 10 & Aventura & Edison Carneiro \\
\hline 8 & 11 & A incrível jornada & Percy Lau \\
\hline 8 & 11 & A incrível jornada & Sergio Soares \\
\hline 8 & 12 & Sentido da nova Humanidade Portuguesa & Afonso de Castro Senda \\
\hline 8 & 15 & Luz al viento & Alvaro Yunque \\
\hline 8 & 16 & Mario Sette, cronista do Recife & Paulo Cavalcanti \\
\hline 8 & 17 & O Penteado de Mme Ronet & Miroel Silveira \\
\hline 8 & 21 & Luiz é um menino Tímido & Melo Lima \\
\hline 8 & 23 & Canción Dispar & Serafin J. Garcia \\
\hline 8 & 24 & Aspectos de Calli & sem autoria \\
\hline 8 & 25 & A Mulher Obscura & Jorge de Lima \\
\hline 8 & 27 & Negros, olhai a aurora & Nilo da Silveira Werneck \\
\hline 8 & 28 & As Almas que ainda não nasceram & Mario Brasiani \\
\hline 8 & 29 & Serafin Garcia, poeta uruguaio & Rui de Carvalho \\
\hline 8 & 31 & Abel Salazar em Lisboa & Jorge Domingues \\
\hline 8 & 33 & Dois Olhos Abertos para o Mundo & Eliezer Burla \\
\hline 8 & 35 & Egoismo & Miguel Bustos Cerecedo \\
\hline 8 & 36 & Canção do Beco, aglomerado humano & Sylvia Leon Chalreo \\
\hline 8 & 37 & Satinador & Jesus Lara \\
\hline 8 & 41 & Anna Amélia de Queiroz Carneiro de Mendonça & sem autoria \\
\hline 8 & 42 & Zungu & Afonso Schmidt \\
\hline 8 & 43 & Literatura não é Divertimento & Abelardo Romero \\
\hline 8 & 44 & O açúcar como Remédio & sem autoria \\
\hline 8 & 45 & Ausência & Deolindo Tavares \\
\hline 8 & 46 & Sem título (sobre a exposição de Portinari no MNBA) & S. (Sylvia) \\
\hline 8 & 47 & Ilustração & sem autoria \\
\hline 8 & 48 & Mazdekismo e Osirismo & Abel Salazar \\
\hline 8 & 51 & A desmoralização da crítica - Cangerão & Dias da Costa \\
\hline 8 & 52 & Seguirei Tranquilo & Aluizio Medeiros \\
\hline 8 & 53 & A Formação do Mundo Moderno & Fabio Crissiuma \\
\hline 8 & 55 & Marta Brunet & Julieta Carrera \\
\hline 8 & 58 & Documentário Cultural Português & Afonso de Castro Senda \\
\hline 8 & 61 & Recordações do Minho Arcaico de Abel Salazar & Carlos Relvas \\
\hline 8 & 63 & Literatura & Editoria \\
\hline 8 & 65 & Maria Jacintha deixa a direção da Esfera & Editoria \\
\hline 8 & 66 & Teatro & Maria Jacintha \\
\hline 8 & 69 & Cinema & sem autoria \\
\hline 8 & 71 & Rádio & Maria Clara \\
\hline 8 & 71 & Jornais e Revistas & sem autoria \\
\hline 6 & 36 & Poema & Augusto de Almeida Filho \\
\hline 1 & 72 & Noel Rosa & S. (Sylvia) \\
\hline
\end{tabular}


Figura 42 - Tabela 3 - RELAÇÃO DAS PROPAGANDAS DE ESTABELECIMENTOS COMERCIAIS E SERVIÇOS, ESFERA, RIO DE JANEIRO, 1938 - 1950

\begin{tabular}{|c|c|c|c|c|c|}
\hline Edição & Pag. & Tam $^{137}$. & Anunciante & Local & Ramo \\
\hline 1 & 12 & $1 / 6$ & Bancária Nacional S.A. & RJ & Mercado Financeiro \\
\hline 1 & 20 & $1 / 4$ & Casa Alhambra & RJ & Comércio - Móveis \\
\hline 1 & 45 & 1 & W. Krebbs & RJ & $\begin{array}{l}\text { Comércio - Máquinas para } \\
\text { escritório }\end{array}$ \\
\hline 1 & 47 & 1 & $\begin{array}{l}\text { Companhia Aliança Industrial do Brasil } \\
\text { Ltda. }\end{array}$ & RJ & Mercado Imobiliário \\
\hline 1 & 54 & $1 / 2$ & Construtora Continental Ltda. & RJ & Mercado Imobiliário \\
\hline 1 & 69 & $1 / 6$ & Perfumaria Carneiro & RJ & $\begin{array}{llll}\text { Comércio } & \text { - Perfumaria } & \text { e } \\
\text { Remédios } & & \\
\end{array}$ \\
\hline 1 & 73 & $3 / 4$ & Indicador - diversos anúncios & RJ & Serviços e Comércio \\
\hline 1 & 74 & $1 / 8$ & Xarope Gil & RJ & $\begin{array}{llll}\text { Comércio } & - \text { Perfumaria } & \mathrm{e} \\
\text { Remédios } & & & \\
\end{array}$ \\
\hline 1 & 74 & $1 / 4$ & Calçados de Luxo OK & RJ & Comércio - Vestuário \\
\hline 1 & 74 & $1 / 6$ & Companhia Auxiliar de Viação e Obras & RJ & Mercado Imobiliário \\
\hline 1 & 74 & $1 / 6$ & Lino e Cia Ltda. & RJ & Mercado Imobiliário \\
\hline 2 & 36 & 1 & $\begin{array}{l}\text { Companhia Aliança Industrial do Brasil } \\
\text { Ltda. }\end{array}$ & RJ & Mercado Imobiliário \\
\hline 2 & 52 & $1 / 6$ & Companhia Auxiliar de Viação e Obras & RJ & Mercado Imobiliário \\
\hline 2 & 53 & $1 / 6$ & Metabril & RJ & Serviços \\
\hline 2 & 54 & $1 / 4$ & Jardim Carioca & RJ & Mercado Imobiliário \\
\hline 2 & 62 & $1 / 6$ & Bancaria Nacional S.A. & RJ & Mercado Financeiro \\
\hline 2 & 64 & $1 / 4$ & Jaime Fernandes & RJ & Serviços \\
\hline 2 & 73 & $1 / 6$ & Casa Alhambra & RJ & Comércio - Móveis \\
\hline 2 & 79 & 1 & Indicador - diversos anúncios & RJ & Serviços e Comércio \\
\hline 3 & 3 & $3 / 4$ & REO & RJ & Comércio - Automóveis \\
\hline 3 & 6 & 1 & Indicador - diversos anúncios & RJ & Serviços e Comércio \\
\hline 3 & 20 & $1 / 6$ & Lino e Cia Ltda. & RJ & Mercado Imobiliário \\
\hline 3 & 44 & $1 / 2$ & Banco Hipotecário Lar Brasileiro & RJ & Mercado Financeiro \\
\hline 3 & 60 & $1 / 6$ & Companhia Auxiliar de Viação e Obras & RJ & Mercado Imobiliário \\
\hline 3 & 66 & $1 / 4$ & Sociedade Brasileira de Urbanismo S.A. & RJ & Mercado Imobiliário \\
\hline 3 & 71 & $1 / 8$ & Escritório Vero & RJ & Serviços \\
\hline 3 & 74 & $1 / 6$ & Casa Alhambra & RJ & Comércio - Móveis \\
\hline 3 & 74 & $1 / 6$ & Metabril & RJ & Serviços \\
\hline 4 & 2 & $1 / 2$ & Indicador - diversos anúncios & RJ & Serviços e Comércio \\
\hline 4 & 10 & $1 / 4$ & Companhia Auxiliar de Viação e Obras & RJ & Mercado Imobiliário \\
\hline 4 & 29 & $1 / 4$ & Sociedade Brasileira de Urbanismo S.A. & RJ & Mercado Imobiliário \\
\hline 4 & 68 & $1 / 3$ & Jardim Carioca & RJ & Mercado Imobiliário \\
\hline 4 & 71 & $1 / 8$ & Escritório Vero & RJ & Serviços \\
\hline 4 & 73 & $1 / 8$ & Casa Alhambra & RJ & Comércio - Móveis \\
\hline 5 & 4 & $1 / 4$ & Indicador - diversos anúncios & RJ & Serviços e Comércio \\
\hline 5 & 24 & $1 / 6$ & Casa Alhambra & RJ & Comércio - Móveis \\
\hline
\end{tabular}

${ }^{137}$ Os tamanhos são aproximações da porcentagem de espaço real que o anúncio ocupa na página. 


\begin{tabular}{|c|c|c|c|c|c|}
\hline 5 & 38 & $1 / 8$ & Xarope Gil & RJ & $\begin{array}{l}\text { Comércio - Perfumaria e } \\
\text { Remédios }\end{array}$ \\
\hline 5 & 56 & $1 / 6$ & Empresa de Despachos Meridional & $\mathrm{RJ}$ & Serviços \\
\hline 5 & 61 & $1 / 6$ & Sul América Seguros & RJ & Mercado Financeiro \\
\hline 5 & 69 & $1 / 8$ & $\begin{array}{l}\text { Serviços de datilografia e tradução, } \\
\text { arquivo e biblioteca }\end{array}$ & RJ & Serviços \\
\hline 5 & 71 & $1 / 6$ & Casa Camelo & $\mathrm{RJ}$ & Comércio - Móveis \\
\hline 5 & 73 & $1 / 8$ & Escritório Vero & RJ & Serviços \\
\hline 5 & 74 & $1 / 4$ & Companhia Auxiliar de Viação e Obras & RJ & Mercado Imobiliário \\
\hline 6 & 2 & $1 / 2$ & Indicador - diversos anúncios & RJ & Serviços e Comércio \\
\hline 6 & 4 & $1 / 6$ & Casa Alhambra & RJ & Comércio - Móveis \\
\hline 6 & 10 & $1 / 8$ & Casa Alhambra & RJ & Comércio - Móveis \\
\hline 6 & 19 & $1 / 4$ & Companhia Auxiliar de Viação e Obras & $\mathrm{RJ}$ & Mercado Imobiliário \\
\hline 6 & 42 & $1 / 4$ & Sociedade Brasileira de Urbanismo S.A. & $\mathrm{RJ}$ & Mercado Imobiliário \\
\hline 6 & 63 & $1 / 2$ & Instituto Alopécico & RJ & 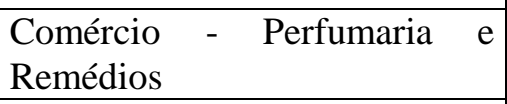 \\
\hline 6 & 65 & $1 / 8$ & Xarope Gil & RJ & $\begin{array}{l}\text { Comércio - Perfumaria } \quad \mathrm{e} \\
\text { Remédios }\end{array}$ \\
\hline 6 & 73 & $1 / 4$ & Banco Hipotecário Lar Brasileiro & $\mathrm{RJ}$ & Mercado Financeiro \\
\hline 6 & 73 & $1 / 8$ & Escritório Vero & $\mathrm{RJ}$ & Serviços \\
\hline 7 & 2 & $1 / 4$ & Indicador - diversos anúncios & $\mathrm{RJ}$ & Serviços e Comércio \\
\hline 7 & 65 & $2 / 3$ & Casa Camelo & $\mathrm{RJ}$ & Comércio - Móveis \\
\hline 7 & 69 & $1 / 6$ & Hotel Avenida & $\mathrm{RJ}$ & Serviços \\
\hline 7 & 71 & $1 / 8$ & Escritório Vero & $\mathrm{RJ}$ & Serviços \\
\hline 8 & 1 & 1 & Casa Nunes & $\mathrm{RJ}$ & Comércio - Vestuário \\
\hline 8 & 4 & $4 / 5$ & Indicador - diversos anúncios & $\mathrm{RJ}$ & Serviços e Comércio \\
\hline 8 & 22 & $1 / 2$ & $\begin{array}{l}\text { Banco do Comércio e Indústria de São } \\
\text { Paulo }\end{array}$ & SP & Mercado Financeiro \\
\hline 8 & 40 & $1 / 8$ & Leite de Alfazema & & $\begin{array}{lll}\text { Comércio } & - \text { Perfumaria } & \mathrm{e} \\
\text { Remédios } & & \\
\end{array}$ \\
\hline 8 & 54 & $1 / 6$ & A Menina Lisieux & RJ & Comércio - Vestuário \\
\hline 8 & 54 & $1 / 6$ & Banco Hipotecário Lar Brasileiro & $\mathrm{RJ}$ & Mercado Financeiro \\
\hline 8 & 62 & $1 / 2$ & Casa Mattos & RJ & Comércio - Papelaria e Livraria \\
\hline 8 & 63 & $1 / 8$ & Escritório Vero & $\mathrm{RJ}$ & Serviços \\
\hline 8 & 65 & $1 / 3$ & Aymoré & $\mathrm{RJ}$ & Comércio - Alimentos \\
\hline 8 & 72 & $1 / 3$ & Colírio Visão & RJ & $\begin{array}{llll}\text { Comércio } & - \text { Perfumaria } & \mathrm{e} \\
\text { Remédios } & & & \\
\end{array}$ \\
\hline 9 & 3 & 1 & Casino Atlântico & RJ & Lazer \\
\hline 9 & 4 & $1 / 4$ & Senun & $\mathrm{RJ}$ & Comércio - Esterelizantes \\
\hline 9 & 4 & $1 / 2$ & $\begin{array}{l}\text { Casa Bancaria Andrade e Cabral e Cia } \\
\text { Ltda }\end{array}$ & RJ & Mercado Financeiro \\
\hline 9 & 4 & $1 / 4$ & Sul America Seguros & & Mercado Financeiro \\
\hline 9 & 6 & 1 & Atlântico Club & RJ & Lazer \\
\hline 9 & 35 & $1 / 2$ & Superbal & RJ & Comércio - Vestuário \\
\hline 9 & 45 & $1 / 8$ & Mate & $\mathrm{RJ}$ & Comércio - Alimentos \\
\hline 10 & 3 & 1 & Guaraná & & Comércio - Alimentos \\
\hline
\end{tabular}




\begin{tabular}{|c|c|c|c|c|c|}
\hline 10 & 4 & $1 / 2$ & Fármacia D. Pedro II & & $\begin{array}{l}\text { Comércio - Perfumaria e } \\
\text { Remédios }\end{array}$ \\
\hline 10 & 4 & $1 / 4$ & Soares, Leal e Cia & RJ & $\begin{array}{l}\text { Comércio Exterior - madeiras } \\
\text { de lei }\end{array}$ \\
\hline 10 & 4 & $1 / 4$ & Sul America Seguros & & Mercado Financeiro \\
\hline 10 & 5 & $1 / 2$ & Aguas São lourenço & RJ & Comércio - Alimentos \\
\hline 10 & 5 & $1 / 2$ & $\begin{array}{l}\text { Cia Química Comercial e Industrial } \\
\text { Brasileira }\end{array}$ & RJ & Indústria \\
\hline 10 & 6 & $1 / 3$ & Emulsão de Scott & & $\begin{array}{llll}\text { Comércio } & - & \text { Perfumaria } & \mathrm{e} \\
\text { Remédios } & & & \\
\end{array}$ \\
\hline 10 & 7 & $1 / 4$ & Alcazar & RJ & Comércio - Alimentos \\
\hline 10 & 7 & $1 / 2$ & Superbal & & Comércio - Vestuário \\
\hline 10 & 52 & & Raios X & & Serviços \\
\hline 11 & 5 & $1 / 3$ & $\begin{array}{l}\text { Cia Química Comercial e Industrial } \\
\text { Brasileira }\end{array}$ & & Indústria \\
\hline 11 & 5 & $1 / 6$ & Confeitaria Colombo & & Mercado Financeiro \\
\hline 12 & 4 & $1 / 3$ & Sul America Seguros & & Mercado Financeiro \\
\hline 12 & 6 & $1 / 3$ & $\begin{array}{l}\text { Cia Química Comercial e Industrial } \\
\text { Brasileira }\end{array}$ & & Indústria \\
\hline 12 & 6 & 1 & Indicador - diversos anúncios & RJ & Serviços e Comércio \\
\hline 13 & 5 & $1 / 3$ & Sul America Seguros & & Mercado Financeiro \\
\hline 13 & 29 & $1 / 3$ & Souza Cruz & & Indústria \\
\hline 13 & 47 & 1 & Indicador - diversos anúncios & RJ & Serviços e Comércio \\
\hline 14 & 6 & 1 & Mate & & Comércio - Alimentos \\
\hline 14 & 7 & 1 & Indicador - diversos anúncios & RJ & Serviços e Comércio \\
\hline 15 & 4 & $1 / 3$ & Sul America Seguros & & Mercado Financeiro \\
\hline 15 & 6 & 1 & Indicador - diversos anúncios & RJ & Serviços e Comércio \\
\hline 15 & 8 & 1 & Mate & & Comércio - Alimentos \\
\hline 15 & 47 & $1 / 3$ & Emulsão de Scott & & $\begin{array}{llll}\text { Comércio } & - \text { Perfumaria } & \mathrm{e} \\
\text { Remédios } & & & \\
\end{array}$ \\
\hline 15 & 49 & $1 / 3$ & Legítima & RJ & Comércio - Alimentos \\
\hline 16 & 4 & 1 & Indicador - diversos anúncios & $\mathrm{RJ}$ & Serviços e Comércio \\
\hline 16 & 6 & $1 / 2$ & Indicador - pintores & RJ & Serviços e Comércio \\
\hline 16 & 46 & $1 / 3$ & Banco Hipotecário Lar Brasileiro & & Mercado Financeiro \\
\hline 16 & 47 & $1 / 2$ & Souza Cruz & & Indústria \\
\hline 16 & 48 & $1 / 3$ & Sul America Seguros & & Mercado Financeiro \\
\hline 16 & 49 & $1 / 2$ & Sal de Fruta Eno & & $\begin{array}{llll}\text { Comércio } & \text { - Perfumaria } & \mathrm{e} \\
\text { Remédios } & & & \\
\end{array}$ \\
\hline 17 & 28 & $1 / 8$ & Procuratório Nelson Cardoso de Almeida? & RJ & Serviços \\
\hline 17 & 29 & $1 / 8$ & Indicador - diversos anúncios & RJ & Serviços e Comércio \\
\hline 18 & 30 & $1 / 3$ & Sal de Fruta Eno & & $\begin{array}{llll}\text { Comércio } & - \text { Perfumaria } & \mathrm{e} \\
\text { Remédios } & & \\
\end{array}$ \\
\hline 18 & 34 & $1 / 4$ & Indicador - diversos anúncios & RJ & Serviços e Comércio \\
\hline 19 & 3 & $1 / 6$ & Indicador - diversos anúncios & RJ & Serviços e Comércio \\
\hline 19 & 30 & $1 / 4$ & A Fortaleza Seguros & & Mercado Financeiro \\
\hline 19 & 32 & $1 / 4$ & Indicador - diversos anúncios & RJ & Serviços e Comércio \\
\hline
\end{tabular}




\begin{tabular}{|l|l|l|l|l|l|}
\hline 19 & 33 & $1 / 6$ & A Capital dos Móveis & & Comércio - Móveis \\
\hline 20 & 3 & 1 & Indicador - diversos anúncios & RJ & Serviços e Comércio \\
\hline 20 & 42 & $1 / 2$ & Indicador - diversos anúncios & RJ & Serviços e Comércio \\
\hline 20 & 43 & $1 / 6$ & Escritório de contabilidade E.C.A.L. & & Serviços \\
\hline 20 & 43 & $1 / 6$ & Pintor Angelo Augusto & RJ & Serviços \\
\hline 20 & 44 & $1 / 2$ & Indicador - diversos anúncios & RJ & Serviços e Comércio \\
\hline 20 & 45 & $1 / 6$ & Hotel Granja Itatiaia & RJ & Serviços \\
\hline 20 & 48 & $1 / 8$ & Colégio Franklin Delano Roosevelt & RJ & Estabelecimento de Ensino \\
\hline 21 & 44 & $1 / 6$ & Sal de Fruta Eno & & $\begin{array}{l}\text { Comércio } \\
\text { Remédios }\end{array}$ \\
\hline 21 & 46 & $1 / 4$ & Empresa Oeste Ltda & & Mercado Imobiliário \\
\hline 21 & 48 & $1 / 6$ & Escritório de contabilidade E.C.A.L. & RJ & Serviços \\
\hline 21 & 48 & $1 / 6$ & Hotel Granja Itatiaia & RJ & Serviços \\
\hline 21 & 48 & $1 / 2$ & Indicador - diversos anúncios & RJ & Serviços e Comércio \\
\hline 21 & 50 & $1 / 8$ & Colégio Franklin Delano Roosevelt & RJ & Estabelecimento de Ensino \\
\hline 21 & 50 & $1 / 2$ & Indicador - diversos anúncios & RJ & Serviços e Comércio \\
\hline 22 & 30 & $1 / 4$ & Empresa Oeste Ltda & RJ & Mercado Imobiliário \\
\hline 22 & 32 & $1 / 3$ & Indicador - diversos anúncios & RJ & Serviços e Comércio \\
\hline 22 & 33 & $1 / 2$ & Indicador - diversos anúncios & RJ & Serviços e Comércio \\
\hline 23 & 32 & $1 / 6$ & Indicador - diversos anúncios & RJ & Serviços e Comércio \\
\hline 23 & 33 & $1 / 4$ & Indicador - diversos anúncios & RJ & Serviços e Comércio \\
\hline 23 & 35 & 1 & Indicador - diversos anúncios & RJ & Serviços e Comércio \\
\hline 24 & 33 & $1 / 3$ & Indicador - diversos anúncios & RJ & Serviços e Comércio \\
\hline 24 & 34 & $1 / 6$ & Indicador - diversos anúncios & RJ & Serviços e Comércio \\
\hline 24 & 35 & 1 & Indicador - diversos anúncios & RJ & Serviços e Comércio \\
\hline & & & & \\
\hline
\end{tabular}

Figura 43 - Tabela 4 - RELAÇÃO DE PROPAGANDAS DE LIVROS, PERIÓDICOS, LIVRARIAS E EDITORAS, ESFERA, RIO DE JANEIRO, 1938 - 1950

\begin{tabular}{|l|l|l|l|l|}
\hline Num. & Pag. & Tam. & Anunciante & Ramo \\
\hline 1 & 8 & $1 / 2$ & Livraria Odeon & Livraria \\
\hline 1 & 12 & $1 / 6$ & Revista Acadêmica & Periódicos \\
\hline 1 & 18 & $1 / 4$ & No que se pensa Hoje & Editora / Livro \\
\hline 1 & 28 & $1 / 6$ & Livraria Boffoni & Livraria \\
\hline 1 & 30 & $1 / 6$ & Edições Pongetti & Editora / Livro \\
\hline 1 & 36 & $1 / 6$ & Surto & Editora / Livro \\
\hline 1 & 44 & $1 / 6$ & O Diabo & Editora / Livro \\
\hline 1 & 50 & $1 / 2$ & Editora SPES & Editora / Livro \\
\hline 1 & 54 & $1 / 2$ & A Tarde & Gráfica \\
\hline 1 & 56 & $1 / 8$ & Olhai os Lírios do campo - Érico Veríssimo & Editora / Livro \\
\hline 1 & 64 & 1 & Dom Casmurro & Periódicos \\
\hline 1 & 70 & $1 / 8$ & Pedra Bonita - José Lins do Rego & Editora / Livro \\
\hline 1 & 70 & $1 / 8$ & Vidas Secas - Graciliano Ramos & Editora / Livro \\
\hline 1 & 74 & $1 / 6$ & Gráfica Olímpica & Gráfica \\
\hline
\end{tabular}




\begin{tabular}{|c|c|c|c|c|}
\hline 2 & 2 & $1 / 8$ & Valeriano & Gravador \\
\hline 2 & 8 & $1 / 6$ & Revista Acadêmica & Periódicos \\
\hline 2 & 16 & $1 / 6$ & Editora SPES & Editora / Livro \\
\hline 2 & 18 & $1 / 6$ & Livraria Boffoni & Livraria \\
\hline 2 & 20 & $2 / 3$ & Livraria Odeon & Livraria \\
\hline 2 & 23 & $1 / 6$ & A Voz da Terra - Amadeu de Queiroz & Editora / Livro \\
\hline 2 & 40 & $1 / 4$ & Edições Pongetti & Editora / Livro \\
\hline 2 & 64 & $1 / 4$ & Letras - boletim & Editora / Livro \\
\hline 2 & 66 & $1 / 6$ & Surto & Editora / Livro \\
\hline 2 & 68 & $1 / 8$ & O Diabo & Editora / Livro \\
\hline 2 & 72 & $1 / 4$ & No que se pensa hoje & Editora / Livro \\
\hline 2 & 78 & 1 & Dom Casmurro & Periódicos \\
\hline 2 & 80 & 1 & Lux Jornal & Periódicos \\
\hline 3 & 3 & $1 / 4$ & Valeriano & Gravador \\
\hline 3 & 4 & $1 / 2$ & Dom Casmurro & Periódicos \\
\hline 3 & 24 & $1 / 6$ & Olhai os lirios do campo - Erico Veríssimo & Editora / Livro \\
\hline 3 & 24 & $1 / 6$ & Porto Inseguro - Rossine Camargo Guarnieri & Editora / Livro \\
\hline 3 & 43 & $1 / 6$ & Letras - boletim & Editora / Livro \\
\hline 3 & 48 & $1 / 2$ & Paris em 1934 - Abel Salazar & Editora / Livro \\
\hline 3 & 50 & $1 / 4$ & Livraria Odeon & Livraria \\
\hline 3 & 62 & $1 / 6$ & Livraria Moura & Livraria \\
\hline 3 & 64 & $1 / 6$ & O Diabo & Periódicos \\
\hline 3 & 70 & $1 / 4$ & Companhia Editora Nacional & Editora / Livro \\
\hline 3 & 72 & $1 / 6$ & No que se pensa Hoje & Periódicos \\
\hline 3 & 72 & $1 / 4$ & Revista Acadêmica & Periódicos \\
\hline 3 & 73 & $1 / 6$ & A Voz da Terra - Amadeu de Queiroz & Editora / Livro \\
\hline 3 & 73 & $1 / 8$ & Criança & Periódicos \\
\hline 3 & 75 & $1 / 2$ & Revista de Portugal & Periódicos \\
\hline 4 & 2 & $1 / 4$ & Expressão & Periódicos \\
\hline 4 & 2 & $1 / 4$ & Revista de Portugal & Periódicos \\
\hline 4 & 30 & $1 / 6$ & A Voz da Terra - Amadeu de Queiroz & Editora / Livro \\
\hline 4 & 30 & $1 / 6$ & Praga de Amor - Amadeu de Queiroz & Editora / Livro \\
\hline 4 & 38 & $1 / 6$ & O Diabo & Periódicos \\
\hline 4 & 46 & $1 / 6$ & Valeriano & Gravador \\
\hline 4 & 73 & $1 / 6$ & Letras - boletim & Periódicos \\
\hline 4 & 73 & $1 / 8$ & Olhai os lirios do campo - Erico Veríssimo & Periódicos \\
\hline 4 & 73 & $1 / 6$ & Universidade & Periódicos \\
\hline 5 & 4 & $1 / 4$ & Expressão & Periódicos \\
\hline 5 & 4 & $1 / 4$ & Lux Jornal & Periódicos \\
\hline 5 & 8 & $1 / 6$ & Zaratrusta Morreu - Heraldo Barbuy & Editora / Livro \\
\hline 5 & 42 & $1 / 8$ & No que se pensa hoje & Periódicos \\
\hline 5 & 48 & $1 / 6$ & Valeriano & Gravador \\
\hline 5 & 52 & $1 / 6$ & A Voz da Terra - Amadeu de Queiroz & Editora / Livro \\
\hline
\end{tabular}




\begin{tabular}{|c|c|c|c|c|}
\hline 5 & 52 & $1 / 6$ & Praga de Amor - Amadeu de Queiroz & Editora / Livro \\
\hline 5 & 62 & $1 / 6$ & Vovó Morungaba - Galeão Coutinho & Editora / Livro \\
\hline 6 & 2 & $1 / 4$ & Renovação & Periódicos \\
\hline 6 & 4 & $1 / 4$ & Lux Jornal & Periódicos \\
\hline 6 & 61 & $1 / 8$ & Cultura & Periódicos \\
\hline 6 & 61 & $1 / 4$ & Expressão & Periódicos \\
\hline 6 & 61 & $1 / 4$ & Mar & Periódicos \\
\hline 6 & 68 & $1 / 6$ & O Diabo & Periódicos \\
\hline 6 & 69 & $1 / 8$ & Criança & Periódicos \\
\hline 7 & 2 & $1 / 4$ & Balas de Estalo - Ernani Lopes & Editora / Livro \\
\hline 7 & 2 & $1 / 4$ & Paris em 1934 - Abel Salazar & Editora / Livro \\
\hline 7 & 12 & $1 / 4$ & Valeriano & Gravador \\
\hline 7 & 21 & $1 / 8$ & Cultura & Periódicos \\
\hline 7 & 36 & $1 / 6$ & O Diabo & Periódicos \\
\hline 7 & 42 & $1 / 4$ & Mar & Periódicos \\
\hline 7 & 42 & $1 / 4$ & Renovação & Periódicos \\
\hline 7 & 45 & $1 / 8$ & No que se pensa hoje & Periódicos \\
\hline 7 & 56 & $3 / 4$ & Companhia Editora Nacional & Editora / Livro \\
\hline 8 & 2 & $1 / 3$ & Livraria Boffoni & Livraria \\
\hline 8 & 4 & $1 / 5$ & Livraria Moura & Livraria \\
\hline 8 & 16 & $1 / 8$ & Sol Nascente & Periódicos \\
\hline 8 & 18 & $2 / 3$ & Cangerão, de Emil Fahrat - José Olympio Editora & Editora / Livro \\
\hline 8 & 19 & $2 / 3$ & $\begin{array}{l}\text { Sob a luz das estrelas - A. J. Cronin trad. Rubem } \\
\text { Braga- José Olympio editora }\end{array}$ & Editora / Livro \\
\hline 8 & 30 & $1 / 4$ & $\begin{array}{l}\text { Memórias de Cinco, Cecílio Carneiro, Casa } \\
\text { Editora Vecchi }\end{array}$ & Editora / Livro \\
\hline 8 & 30 & $1 / 4$ & $\begin{array}{l}\text { Tobias Barreto, Omer Mont'alegre, Casa Editora } \\
\text { Vecchi }\end{array}$ & Editora / Livro \\
\hline 8 & 32 & $1 / 8$ & Terra de Mafrense - Revista da Colônia Piauiense & Periódicos \\
\hline 8 & 44 & $1 / 8$ & Renovação & Periódicos \\
\hline 8 & 50 & $1 / 8$ & Criança & Periódicos \\
\hline 8 & 50 & $1 / 8$ & No que se pensa hoje & Periódicos \\
\hline 8 & 56 & $1 / 3$ & Cadernos do Centenário Português - ELP & Periódicos \\
\hline 8 & 56 & $1 / 3$ & Dom Casmurro & Periódicos \\
\hline 8 & 60 & $1 / 6$ & O Diabo & Periódicos \\
\hline 8 & 64 & $1 / 8$ & Cordeiro de Andrade - Tonio Borba & Editora / Livro \\
\hline 8 & 68 & $1 / 4$ & Livraria Odeon & Livraria \\
\hline 8 & 71 & $1 / 8$ & Valeriano & Gravador \\
\hline 9 & 30 & $1 / 3$ & Leitura & Periódicos \\
\hline 9 & 40 & $1 / 2$ & Liberdade Literária & Periódicos \\
\hline 10 & 6 & $2 / 3$ & Stalin - Henri Barbusse & Editora / Livro \\
\hline 10 & 7 & $1 / 4$ & ELP - livros e revistas de Portugal & Editora / Livro \\
\hline 10 & 51 & 1 & Editorial Calvino - livros marxismo & Editora / Livros Marxistas \\
\hline 10 & 52 & & Edições Estrela Azul & Editora / Livro \\
\hline
\end{tabular}




\begin{tabular}{|c|c|c|c|c|}
\hline 10 & 52 & $01 / \mathrm{abr}$ & Editora Brasiliense & Editora / Livro \\
\hline 10 & 52 & $1 / 6$ & URSS & Editora / Livro \\
\hline 11 & 5 & & Amaral e Coutinho e Cia Ltda & Editora / Livros Marxistas \\
\hline 11 & 6 & & Edições Estrela Ltda. & Editora / Livro \\
\hline 11 & 12 & $1 / 6$ & História da Filosofia - - Editorial Vitória & Editora / Livro \\
\hline 11 & 26 & $1 / 6$ & Edições Estrela Vermelha - Tacão de Ferro & Editora / Livro \\
\hline 11 & 31 & $1 / 6$ & $\begin{array}{l}\text { História da época do capitalismo industrial - A. } \\
\text { Efimov - Editorial Vitória }\end{array}$ & Editora / Livro \\
\hline 11 & 33 & $1 / 6$ & História do PC da URSS - Editorial Vitória & Editora / Livro \\
\hline 11 & 50 & 1 & Antologia de Artistas Plásticos - ELP - E P Sigaud & Editora / Livro \\
\hline 12 & 3 & 1 & Editorial Calvino - livros marxismo & Editora / Livros Marxistas \\
\hline 12 & 4 & 1 & Livraria Rex & Livraria \\
\hline 12 & 4 & 1 & O dinheiro - E. Zola - Edicao Estrela Ltda & Editora / Livro \\
\hline 12 & 5 & & Ediçoes Estrela & Editora / Livro \\
\hline 12 & 5 & & Edições Estrela Azul & Editora / Livro \\
\hline 12 & 5 & $1 / 6$ & Edições Estrela Vermelha - Tacão de Ferro & Editora / Livro \\
\hline 12 & 6 & & Antologia de Artistas Plásticos - ELP - E P Sigaud & Editora / Livro \\
\hline 12 & 10 & 1 & Edições Estrela Ltda. & Editora / Livro \\
\hline 12 & 30 & $1 / 6$ & Esfera & Periódicos \\
\hline 12 & 36 & $1 / 2$ & Edições Horizonte Ltda & Editora / Livro \\
\hline 12 & 42 & $1 / 3$ & Esfera & Periódicos \\
\hline 12 & 45 & $1 / 6$ & Revista do Povo & Periódicos \\
\hline 12 & 50 & $1 / 2$ & $\begin{array}{l}\text { Antologia de Pintores Brasileiros - A. Galvão - } \\
\text { ELP }\end{array}$ & Editora / Livro \\
\hline 13 & 3 & 1 & Editorial Calvino - livros marxismo & Editora / Livros Marxistas \\
\hline 13 & 4 & $1 / 3$ & Edições Estrela Vermelha - Tacão de Ferro & Editora / Livro \\
\hline 13 & 4 & $1 / 3$ & Revista do Povo & Periódicos \\
\hline 13 & 5 & 1 & Livraria Rex & Livraria \\
\hline 13 & 7 & 1 & $\begin{array}{l}\text { A Defesa Acusa - Marcel Williard - Editorial } \\
\text { Calvino }\end{array}$ & Editora / Livro \\
\hline 13 & 8 & 1 & O dinheiro - E. Zola - Edicao Estrela Ltda & Editora / Livro \\
\hline 13 & 10 & 1 & Edições Estrela Ltda. & Editora / Livro \\
\hline 13 & 22 & $1 / 2$ & Álbum de desenhos - Paulo Werneck - ELP & Editora / Livro \\
\hline 13 & 34 & $1 / 2$ & $\begin{array}{l}\text { Antologia de Pintores Brasileiros - A. Galvão - } \\
\text { ELP }\end{array}$ & Editora / Livro \\
\hline 13 & 36 & $1 / 4$ & Esfera & Periódicos \\
\hline 13 & 41 & $1 / 6$ & Esfera & Periódicos \\
\hline 14 & 3 & 1 & Editorial Calvino - livros marxismo & Editora / Livros Marxistas \\
\hline 14 & 4 & $1 / 3$ & Amaral e Coutinho e Cia Ltda & Editora / Livros Marxistas \\
\hline 14 & 4 & $1 / 3$ & Edições Estrela Vermelha - Tacão de Ferro & Editora / Livro \\
\hline 14 & 5 & 1 & O dinheiro - E. Zola - Edicao Estrela Ltda & Editora / Livro \\
\hline 14 & 6 & 1 & Livraria Rex & Livraria \\
\hline 14 & 10 & 1 & Edições Estrela Ltda. & Editora / Livro \\
\hline 14 & 20 & $1 / 3$ & Esfera & Periódicos \\
\hline
\end{tabular}




\begin{tabular}{|c|c|c|c|c|}
\hline 14 & 34 & $1 / 6$ & Revista do Povo & Periódicos \\
\hline 14 & 38 & $1 / 8$ & Esfera & Periódicos \\
\hline 14 & 48 & $1 / 3$ & Hoje & Periódicos \\
\hline 14 & 49 & 1 & W. M. Jackson Editores & Editora / Livro \\
\hline 14 & 50 & $1 / 3$ & Agenda Carioca & Periódicos \\
\hline 14 & 50 & $1 / 3$ & Editorial Calvino - livros marxismo & Editora / Livros Marxistas \\
\hline 15 & 4 & $1 / 3$ & Amaral e Coutinho e Cia Ltda & Editora / Livros Marxistas \\
\hline 15 & 4 & $1 / 3$ & Edições Estrela Vermelha - Tacão de Ferro & Editora / Livro \\
\hline 15 & 5 & 1 & O dinheiro - E. Zola - Edicao Estrela Ltda & Editora / Livro \\
\hline 15 & 7 & 1 & Livraria Rex & Livraria \\
\hline 15 & 10 & 1 & Edições Estrela Ltda. & Editora / Livro \\
\hline 15 & 24 & 1 & Folha do Dia & Periódicos \\
\hline 15 & 39 & $1 / 6$ & Esfera & Periódicos \\
\hline 15 & 43 & $1 / 2$ & Hoje & Periódicos \\
\hline 15 & 45 & $1 / 3$ & Editorial Vitória Ltda & Editora / Livro \\
\hline 15 & 46 & $1 / 2$ & Revista do Comércio & Periódicos \\
\hline 15 & 48 & $1 / 3$ & Esfera & Periódicos \\
\hline 15 & 48 & $1 / 3$ & Revista Glamour & Periódicos \\
\hline 15 & 50 & $1 / 4$ & Editorial Vitória Ltda & Editora / Livro \\
\hline 15 & 50 & $1 / 4$ & Leia-me & Periódicos \\
\hline 16 & 3 & 1 & Editorial Calvino - livros marxismo & Editora / Livros Marxistas \\
\hline 16 & 4 & 1 & Livraria Rex & Livraria \\
\hline 16 & 8 & 1 & Edições Estrela Ltda. & Editora / Livro \\
\hline 16 & 30 & $1 / 2$ & Revista de Portugal - ELP & Periódicos \\
\hline 16 & 45 & $1 / 3$ & Hoje & Periódicos \\
\hline 16 & 46 & $1 / 3$ & Revista do Comércio & Periódicos \\
\hline 17 & 3 & $1 / 3$ & Antologia de Artistas Plásticos - ELP & Editora / Livro \\
\hline 17 & 20 & $1 / 4$ & Editorial Vitória Ltda & Editora / Livro \\
\hline 17 & 26 & $1 / 6$ & Literatura & Periódicos \\
\hline 17 & 32 & $1 / 4$ & Eramos Irmãos - Hugo Rocha & Editora / Livro \\
\hline 17 & 32 & $1 / 6$ & Momento Feminino & Periódicos \\
\hline 18 & 3 & $1 / 3$ & Antologia de Artistas Plásticos - ELP & Editora / Livro \\
\hline 18 & 3 & $1 / 8$ & Literatura & Periódicos \\
\hline 18 & 12 & $1 / 8$ & ELP - livros e revistas de Portugal & Editora / Livro \\
\hline 18 & 21 & $1 / 6$ & Literatura & Periódicos \\
\hline 18 & 22 & $1 / 8$ & Momento Feminino & Periódicos \\
\hline 18 & 26 & $1 / 6$ & Editorial Vitória Ltda & Editora / Livro \\
\hline 19 & 31 & $1 / 6$ & Dragão do Mar - Edmar Morel & Editora / Livro \\
\hline 20 & 4 & $1 / 3$ & Esfera & Periódicos \\
\hline 20 & 41 & $1 / 8$ & Poemas do meio dia - Maura de Senna Pereira & Editora / Livro \\
\hline 20 & 47 & $1 / 8$ & Dragão do Mar - Edmar Morel & Editora / Livro \\
\hline 20 & 49 & $1 / 8$ & Momento Feminino & Periódicos \\
\hline 20 & 50 & $1 / 6$ & Literatura & Periódicos \\
\hline
\end{tabular}




\begin{tabular}{|l|l|l|l|l|}
21 & 4 & 1 & ELP - Pedidos de catálogos & Editora / Livro \\
\hline 21 & 45 & $1 / 8$ & ELP - livros e revistas de Portugal & Editora / Livro \\
\hline 21 & 47 & $1 / 8$ & Morada da Paz - Jorge Medauar - Ed. Brasiliense & Periódicos \\
\hline 22 & 4 & 1 & ELP - Pedidos de catálogos & Editora / Livro \\
\hline 22 & 21 & $1 / 6$ & ELP - livros e revistas de Portugal & Editora / Livro \\
\hline 22 & 34 & $1 / 8$ & Momento Feminino & Periódicos \\
\hline 23 & 2 & $1 / 3$ & ELP - livros e revistas de Portugal & Editora / Livro \\
\hline 24 & 2 & $1 / 3$ & ELP - livros e revistas de Portugal & Editora / Livro \\
\hline 24 & 32 & $1 / 8$ & ELP - livros e revistas de Portugal & Editora / Livro \\
\hline 24 & 36 & 1 & Imprensa Médica & Periódicos \\
\hline
\end{tabular}

Figura 44 - Tabela 5 - RELAÇÃO DE PROPAGANDAS DE EMPRESAS DE RADIODIFUSÃO, ESFERA, RIO DE JANEIRO, 1938

\begin{tabular}{|l|l|l|l|l|}
\hline Número & Página & Tamanho & Anunciante & Local \\
\hline 1 & 4 & $7 / 8$ & Rádio Vera Cruz S.A & RJ \\
\hline 2 & 2 & $3 / 4$ & Rádio Vera Cruz S.A & RJ \\
\hline 3 & 2 & $1 / 2$ & Rádio Ipanema & RJ \\
\hline 3 & 75 & $1 / 2$ & Rádio Ipanema & RJ \\
\hline 3 & 4 & $1 / 2$ & Rádio Vera Cruz S.A & RJ \\
\hline 4 & 69 & $1 / 2$ & Rádio Ipanema & RJ \\
\hline 4 & 74 & 1 & Rádio Transmissora Brasileira & RJ \\
\hline 4 & 70 & $1 / 2$ & Rádio Vera Cruz S.A & RJ \\
\hline 5 & 70 & $1 / 4$ & Rádio Ipanema & RJ \\
\hline
\end{tabular}




\section{4 - A TÍTULO DE CONCLUSÃO: MODERNA, FEMINISTA E COMUNISTA}

Paralelamente às atividades na Esfera, Silvia continuou a colaborar como redatora chefe, crítica de artes plásticas e teatro e repórter. Escreveu entre outros periódicos para as revistas Rio e Rio Social e os jornais Tribuna Popular e O Momento Feminino, que circulavam no Rio de Janeiro. O Tribuna Popular era a mais difundida publicação de esquerda brasileira, tendo chegado, no seu auge, a se igualar em tiragem com os jornais mais vendidos no período.

Dirigido e organizado por mulheres, O Momento Feminino, primeiro periódico do PCB totalmente dedicado a elas, alcançou tal projeção que em seu primeiro aniversário, em 6 de agosto de 1948, recebeu mensagens de órgãos da imprensa e de organizações femininas de diferentes pontos do País, da Argentina e do Uruguai. Neste dia, em seu editorial, o jornal se definia "como um órgão educacional e orientador da mulher brasileira" e voltado para a "vida da gente pobre e sofredora dos morros e das favelas em reportagens que comovem, revoltam e mostram quanto ainda temos que lutar por uma perfeita justiça social".

Desde o final da década de 1930, com mais de trinta anos, solteira e financeiramente independente, Silvia expressava uma ideia sobre a posição da mulher, que ia além da busca de mudanças na vida profissional, intelectual e política, como acontecia com as feministas da geração anterior com quem havia convivido na juventude. Em um recorte de jornal guardado em uma das pastas Sobre Silvia há um artigo que representa esta transformação: publicada em Portugal, na Página da Mulher do jornal A Ideia Livre da cidade de Anadia (distrito de Aveiro), a matéria intitulada Mentalidade Feminina Brasileira, de Afonso de Castro Senda, faz uma crítica às mulheres intelectuais daquele período no Brasil e em Portugal:

Lá como cá, a média, mesmo daquelas mulheres que se dedicam a atividade intelectual, anda muito próximo da mediocridade" e acrescenta que o feminismo "faz-se arrancando a pouco e pouco a mulher desta inferioridade e fazendo-a subir a um grau de conscientização propício a criação de sua personalidade.

E apresenta Sylvia como uma das poucas exceções a esta regra, a "verdadeira mulher moderna”, para quem "a união sexual é sempre uma dignificação de vida”. Acrescentando que era uma 
[...] pessoa que ultrapassou aquela amorfa e oca sentimentalidade do ambiente médio, para, com a solidez que dão a harmonização de uma cultura bem apreendida e uma mentalidade invulgar perder este coquetismo balofo de menina de boa família ${ }^{138}$.

Também reproduz trechos de textos que atribui a ela: "É preciso que o congresso sexual não seja uma servidão"; "sem a poesia, que é a seiva, o mecanismo no amor é repugnante, mata os sentidos"; "o homem e a mulher quando perdem as características peculiares ficam desfigurados"; "para o entrelaçamento sexual é indispensável uma afinidade especial, variável segundo o temperamento de cada ser"'139.

$* * * * *$

Sua vida íntima não seguiu o esperado para uma mulher de sua classe social, pois não casou nem teve filhos. Em 1956, mudou-se com a mãe, uma tia, o ator João Ângelo Labanca e Pedro Weiss Xavier, um militar vinte e quatro anos mais jovem, para o apartamento que comprou no Flamengo, onde todos viveram até morrer. O último foi Pedro, que faleceu em 2004. A relação entre eles ainda hoje é duvidosa. Para os familiares de Pedro Xavier eram amigos; para o galerista Jacques Ardies, sua esposa Lucia e a vizinha Ana Maria, eram um casal com filho. Em entrevista de $1967^{140}$, Silvia chama Labanca de meu marido. Oficialmente, no entanto, não tinham nenhum vínculo. O único papel que os unia era um testamento onde se declaravam beneficiários um dos outros.

Considerando que as contradições e tensões entre os diferentes discursos feministas existentes desde o início do século XX revelam a resistência a mudanças que abalam a estrutura familiar, base da sociedade patriarcal e capitalista, este futuro de Silvia e as lacunas no arquivo referentes a sua participação no $\mathrm{PCB}$, finalizo com a uma reflexão que diz respeito às práticas cotidianas de artistas e intelectuais, muitas vezes dissociadas de seus discursos.

Ter uma família diferente podia ser um caso raro entre os anos 1950 e 1980, mas o medo que os indivíduos que se afastavam do comportamento convencional, reforçando as violências sofridas em decorrência desta condição, contribuiu substancialmente para a falta de conhecimento sobre estas famílias. A coragem de enfrentar estas violências com coerência parece ser a única forma de transformar, como diz Jessé de Souza, o "DNA simbólico e cultural" (SOUZA, 2009) de nossa sociedade, que vê a família como um agregado de pessoas unidas por vínculos biológicos, negando o amor como única condição necessária para sua constituição, perpetuando o estereótipo de família heteronormativa que se impõe em nossa

\footnotetext{
${ }^{138}$ Grifo de Afonso de Castro Senda.

${ }^{139} \mathrm{O}$ recorte de jornal foi enviado por Afonso para Sylvia, com um comentário dele manuscrito sobre um trecho do artigo.

${ }^{140}$ Programa Fatos e Ideias, Rádio Ministério da Educação, 1967.
} 
sociedade em oposição às formações familiares como a de Silvia, que ficaram escondidas e silenciadas pela história.

A Esfera por sua vez, deixou registrada uma rede internacional de escritores e artistas cujos ideais de combate às desigualdades econômicas, de gênero e raça estão longe de serem atingidos e cuja luta ficou esquecida pela história. Atualmente o valor das obras publicadas e da revista vista como um documento único está ligado à representação desta rede que expressava a oposição de uma parcela da classe artística e intelectual aos regimes autoritários e ao sistema capitalista. A perseguição aos comunistas realizada pela ditadura Vargas e posteriormente pela ditadura militar foram importantes agentes para o enfraquecimento de sua luta, mas o seu esquecimento também foi decorrente do trabalho de historiadores, jornalistas e críticos que incluíram suas obras na memória da arte e literatura brasileira desconsiderando o interesse político que os unia, de divulgar, denunciar as injustiças sociais e lutar por mudanças sociais. Considerando que o vazio encontrado no arquivo sobre a participação de Silvia no PCB e na ANL possivelmente se repete em arquivos de outros intelectuais e artistas integrantes do Partido e do movimento antifascista das décadas de 1930 e 1940, podemos acrescentar outro agente para este esquecimento: assim como a perseguição política e a construção das narrativas sobre arte e literatura desvinculadas do seu contexto sócio político, o medo, o preconceito introjetado, a sedução pelo poder e prestígio e a incoerência entre os discursos e práticas individuais de artistas e intelectuais no cotidiano e na vida privada contribuíram para que suas lutas, ideias e ideais estejam esquecidos e ausentes da historiografia. 


\section{REFERÊNCIAS BIBLIOGRÁFICAS}

ALVES, I.C. A política no feminino: Uma História das Mulheres no Partido Comunista do Brasil Seção Bahia (1942-1949); Dissertação de mestrado; Faculdade de História; Universidade Estadual de Feira de Santana; 2015.

AMARAL, Aracy A; Arte Para Quê? A Preocupação Social na Arte Brasileira, 1930-1970: Subsídios para uma História Social da Arte no Brasil; São Paulo; Estúdio Nobel; 2003.

AMIN, R. O Clube dos Artistas Modernos: Um celeiro de encontros insólitos. Anais do $20^{\circ}$ Encontro Nacional da ANPAP. Belém: ANPAP/PPGARTES/ICA/UFPA. 2011. p. 2580 - 2595.

ANDRADE, L. C. Um Rasgo Vermelho Sobre o Oceano: Intelectuais e Literatura Revolucionária no Brasil e em Portugal: A Revista Esfera e a Aproximação Luso-Brasileira. In: Guimarães, Lúcia Maria Paschoal (org). Afinidades Atlânticas; Editora Faperj; Rio de Janeiro, 2009.

ANDRADE, M. Uma Suave Rudeza. In: Empalhador de Passarinhos. São Paulo: Martins; Brasília: INL, 1972, pp. 66-67. Texto publicado inicialmente no jornal Diário de Lisboa, em 20 de julho de 1939.

ARTIÈRES, P. Arquivar a própria vida. Revista Estudos Históricos, Rio de Janeiro, v. 11, n. 21, p. 9-34, jul. 1998. ISSN 2178-1494.

ASSIS, A.A. Um lampião dentro da mala: o arquivo pessoal de Octávio Leal Pacheco - memória e autobiografia; dissertação de mestrado; Universidade Federal de São João Del-Rei; 2009.

AVELAR, A. S. A biografia como escrita da História: possibilidades, limites e tensões. Revista Dimensões, vol. 24, 2010, p. 157-172.

BECKER, H. S. Mundos da Arte, Livros Horizonte Ltda, Lisboa, 2008.

BENZECRY, Lena. A radiodifusão sonora do samba urbano carioca: uma retrospectiva crítica das principais representações construídas acerca desse gênero musical em programas radiofônicos do Rio de Janeiro. Tese (Doutorado), Escola de Comunicação, Universidade Federal do Rio de Janeiro, 2015. 
BOtelho, J. M. G. Nos Tempos da Baruel. Ângulo, São Paulo, n. 137, 44 - 46, Abril - Junho 2014.

BOURDIER, P. A ilusão Biográfica, in: Razões práticas sobre a teoria da ação; Lisboa; Celta, 1997, $53-59$.

CARDOSO, R. G. Os Salões de Maio e a crítica de arte: modernismo, surrealismo e abstração. Pós, Belo Horizonte, v. 5, n. 10, p. 130 - 143, novembro 2015

CASTRO, R. F. As esquerdas e o processo constituinte; História Social n²; Campinas,1997.

CAVAlCANTI, C. Organização. Dicionário Brasileiro de Artistas Plásticos, Ministério da Educação e Cultura, Instituto Nacional do Livro, 1974.

CIPRIANO, L. A. G. Mário de Andrade e o Conceito de nacionalismo na música; dissertação de mestrado, ECA-USP, 2011.

COELHO, F. A Semana sem Fim: celebrações e memória da Semana de Arte Moderna de 1922, Casa da Palavra, Coleção Modernismo + 90, 2012. CPDOC, FGV, 1998.

CORTE, A. T. Os judeus em Niterói: imigração, cidade e memória (1910 - 1980); Tese de doutoramento; Universidade Federal Fluminense; Instituto de Ciências Humanas e Filosofia; Rio de Janeiro; 2009.

COSCENZA, A. C. Um partido, duas táticas: Uma história organizativa e política do Partido comunista Brasileiro (PCB) de 1922 a 1935; dissertação de mestrado; FFLCH-USP; 2012.

COSTA, H. D. O. A insurreição comunista de 1935. Natal: UFRN, 2015

COSTA, R. Teoria e História: A produção político cultural do PCB dos anos 30 aos 60. Fundação Dinarco Reis, 2016. Disponivel em: <https://fdinarcoreis.org.br/fdr/2012/06/28/a-producaopolitico-cultural-do-pcb-dos-anos-30-aos-60/>. Acesso em: 15 agosto, 2018.

D’ONOFRIO, S. C. T. O Grupo da Baruel e a Intelectualidade Paulista dos Anos 1940; Tese (Doutorado em História); Faculdade de Filosofia, Ciências e Letras - USP, São Paulo, 2017 
DIAS, L. A. C. C. Roteiro da Imprensa Cultural Juvenil dos anos trinta. Tese (doutorado em Letras), Faculdade de Letras, Universidade de Coimbra, Coimbra, 2011. Disponível em <https://core.ac.uk/download/pdf/19132905.pdf>. Acesso em: 26/09/2018

DIAS, L. A. C. O "Vértice" de uma renovação cultural: imprensa periódica na formação do NeoRealismo (1930-1945), Coimbra [s.n.], 2011.

DOSSÉ, F. A História. EDUSC, Bauru/SP, 2004.

DURAND, J. C. Arte, privilégio e distinção; Perspectiva - Editora da Universidade de São Paulo, 1989.

FABRIS, A. Modernidade e modernismo no Brasil. Campinas: Mercado das Letras, 1994.

FARGE, A. O sabor do arquivo. São Paulo: Editora da Universidade de São Paulo, 2009.

FAUSTO, B. O crime do restaurante chinês: carnaval, futebol e justiça na São Paulo dos anos 30. São Paulo: Companhia das Letras, 2009.

FERNANDES, M. J. S. Café Paris: os precursores; Ed. Novas Idéias: Niterói, 2014.

FERREIRA, A. A. Teatro ligeiro cômico do Rio de Janeiro. Tese (Doutorado em Letras Clássicas e Vernáculas); FFLCH, USP, 2010.

FERREIRA, J. L. Gilberto Freyre e Câmara Cascudo, entre a tradição, o moderno e o regional, tese (doutorado em letras), Centro de Ciências Humanas, Letras e Artes, Universidade Federal do Rio Grande do Norte, 2008.

FORTE, G. N. Carlos Prado, trajetória de um modernista aristocrata. Campinas: Tese de doutorado em Sociologia, Faculdade de Filosofia e Ciências Humanas, Unicamp, 2014.

FORTES, G. N. CAM e SPAM: arte, política e sociabilidade na São Paulo moderna, do início dos anos 1930, Dissertação de Mestrado em História Social, FFLCH, USP, 2008.

GINZBURG, C. Mitos, Emblemas e Sinais. São Paulo: Cia. das Letras, 1989, p. 177. 
GOLIN, C.; RAMOS, P. V. Jornalismo cultural no Rio Grande do Sul: a modernidade nas páginas da revista Madrugada (1926). Revista FAMECOS, Porto Alegre, p. 106 - 114, agosto 2007.

GOMES, A. C. Escrita de si, escrita da História: a título de prólogo. Rio de Janeiro: Editora FGV, 2004.

GOMES, A. M. C. A escrita da história nos palcos: Teatro histórico e crítica literária na Marquesa de Santos. Varia hist., Belo Horizonte, v. 34, n. 66, p. 669-698, dez. 2018. Disponível em <http://www.scielo.br/pdf/vh/v34n66/0104-8775-vh-34-66-0669.pdf>. Acesso em 13 fev. 2019. http://dx.doi.org/10.1590/0104-87752018000300005.

HEYMANN, L.Q. Indivíduo, memória e resíduo histórico: uma reflexão sobre arquivos pessoais e o caso Filinto Müller. Revista Estudos Históricos, Rio de Janeiro, v. 10, n. 19, p. 41-60, jul. 1997.

LEITE, L. B. A Mulher no Teatro Brasileiro. Rio de Janeiro: Espetáculo, 1965.

LEJEUNE, P. O guarda-memória. Revista Estudos Históricos, Rio de Janeiro, v. 10, n. 19, p. 111120, jul. 1997. ISSN 2178-1494.

LEJEUNE, P. O pacto autobiográfico: de Rousseau à internet. Editora UFMG, 2014.

LOPEZ, A. P. A. Como descrever documentos de arquivo: elaboração de instrumentos de pesquisa; São Paulo: Arquivo do Estado, Imprensa oficial, 2002

MARTINS, A. L. Revistas em Revista: Imprensa e práticas Culturais em Tempos de República (1890 - 1922), Edusp, São Paulo, 2008.

MEDEIROS, J. Dicionário dos Pintores do Brasil; Editora Irradiação Cultural, 1988.

MONTEIRO, E. M. A Revista, modernismo e identidade fluminense (1919 - 1923); dissertação de mestrado; História Social da Cultura; PUC-RJ, 2008.

NAPOLITANO, M. A breve primavera antes do longo inverno: uma cartografia histórica da cultura brasileira antes do golpe de Estado de 1964; Revista História Unisinos; Vol. 18 No 3 , setembro/dezembro de 2014 
OLIVEIRA, Â. M. D. Intelectuais antifascistas no Cone Sul: Experiências associativas no cruzamento entre cultura e a política (1933-1939). Projeto História, São Paulo, p. 53-83, agosto 2013.

OLIVEIRA, E. D. G. O pioneirismo do Recife: Diferentes Semanas de Arte de 1922: Apropriações Periféricas. Anais do XXVI Simpósio Nacional de História - ANPUH; São Paulo, julho 2011. Disponível em: <http://www.snh2011.anpuh.org/resources/anais/14/1300313786_ARQUIVO_ANPUH2011.pdf>. Acesso em: 12/09/2018.

OLIVEIRA, L. L. Manuel Bonfim, autor esquecido ou fora do tempo? Sociologia \& Antropologia, 5(3), 771-797, 2015.

OliVEIRA, M. A Participação Goiana na Construção de Brasília, Sociedade e Cultura, V. 8, N. 1,2005, p.99.

OTTONI, A. Bibliografia Brasileira de Teatro (1938-1943). Dionysos, Rio de Janeiro, n.1 [pchave:] OTTONI, Áureo. Bibliografia Brasileira de Teatro (1944-1948). Dionysos, Rio de Janeiro, n. 2, pp. 102-109, jun. 1952.

PAIVA, V. A literatura brasileira em Portugal nos anos 1930. In: MACEDO, A. G.; SOUZA, C. M. D.; MOURA, V. Humanidades: novos paradigmas do conhecimento da investigação. 1a. ed. Braga: HÚMUS, 2013. p. 101-122.

PAULA, C. J. e LATTMAN-WELTMAN, F. Dicionário Histórico Biográfico Brasileiro. Rio de Janeiro: CPDOC - FGV, 2010. Disponível em http://www.fgv.br/cpdoc/acervo/dicionarios/verbetebiografico/antonio-de-padua-chagas-freitas. Acesso em 10/11/2018.

PERROT, M. Minha história das mulheres; São Paulo; Contexto; 2007.

PINHEIRO, A. V. M. A. Pulsão irrefreável: gênero, artes visuais e políticas públicas; dissertação de mestrado; Políticas Públicas e Sociedade; Universidade Estadual do Ceará; 2007

POMIAN, K. Coleção. Memória-História. ENCICLOPÉDIA EINAUDI. Vol. 1. Lisboa, Imprensa Nacional/Casa da Moeda, 1984. 
PROCHASSON, C. "Atenção: Verdade!" - Arquivos Privados e Renovação das Práticas Historiográficas, In Revista Estudos Históricos.

QUEIROZ, A. L.; ZOET, M. Maracangalha: Vida e Obra de Sylvia de Leon Chalreo; Illumina, 2014.

RAGO, M. Trabalho feminino e sexualidade; in História das Mulheres no Brasil; Mary Del priori (org.); São Paulo, Contexto, 2003.

RAGO, E. J. Gênero, medicina, história, Anais do XXVI Simpósio Nacional de História - ANPUH: São Paulo, julho 2001.

RAMOS, A. S. Por um feminismo bem comportado: educação, maternidade e trabalho nas páginas da revista Brasil Feminino (1932-1934), Anais eletrônicos do XVI Encontro Estadual de História da ANPUH-SC, 2016. http://www.encontro2016.sc.anpuh.org/conteudo/view?ID_CONTEUDO=1889. Acesso em 20/09/2017.

RIBEIRO, J. A. P. Guignard e o ambiente artístico no Brasil nas décadas de 1930 e 1940; Dissertação (Mestrado em Artes Visuais), Escola de Comunicações e Artes, USP, 2009.

RIBEIRO, M. A. O modernismo brasileiro: arte e política. ArtCultura, Uberlândia, p. 115 - 125, jan. - jun. 2007.

ROMANELLI, M. A representatividade feminina na literatura brasileira contemporânea. Rio de Janeiro: Monografia, Bacharelado em Comunicação Social; Escola de Comunicação, UFRJ, 2014.

SABINO, Ignez. Mulheres Ilustres do Brasil. Rio de Janeiro: Editora das Mulheres, 1996. Disponível em: <https://books.google.com.br/books?id=fHJmAAAAMAAJ\&hl=ptPT\&pg=PA193\#v=onepage \&q\&f=false $>$. Acesso em 28/03/2019.

SALLA, T. M. A divulgação de Graciliano Ramos em Portugal nas páginas da Revista Atlântico: Suporte e Atenuação do Sentido; Via Atlântica; São Paulo; no 31; 59 - 78; 2017.

SALLA, T. M. Graciliano Ramos, do outro lado do Atlântico: a difusão e a recepção da obra do autor de Vidas Secas em Portugal entre as Décadas de 1930 e 1950; Tese de doutorado; Departamento de Letras Clássicas e Vernáculas; FFLCH; 2016. 
SALLA, T. M. Primórdios da Recepção de Graciliano Ramos em Portugal: a Chegada do Autor de Vidas Secas em Terras Portuguesas no Final dos Anos 1930. In: Comparativismo Contemporâneo; Org. VASCONCELLOS, M.S., SILVA, R.V.D; São Paulo; FFLCH - USP; 2017.

SALLES, Vicente. Guajarina, folhetaria de Francisco Lopes. Revista Brasileira de Cultura, n. 9. p. $87-102$, jul./set. 1971 .

SCHMIDT, B. B. Biografia e regimes de historicidade. Revista Métis: história \& cultura - v. 2, n. 3, p. 57-72, jan./jun. 2003

SCHMIDT, B. B. Construindo biografias...Historiadores e jornalistas: aproximações e afastamentos; Revista Estudos Históricos, Rio de Janeiro, v. 10, n. 19, p. 3-22, jul. 1997. ISSN 21781494. Disponível em: http://bibliotecadigital.fgv.br/ojs/index.php/reh/article/view/2040Acesso em: 26 Ago. 2017.

SEIXAS, C. Modernismo e diversidade: impasses e confrontos de uma vertente regional. Légua \& meia: Revista de literatura e diversidade cultural. Feira de Santana: UEFS, v. 3, nº 2, 2004, p. 52-61.

SILVA, J., D. Ibsen no Brasil: Historiografia, Seleção de Textos e Catálogo Bibliográfico. Dissertação (Mestrado em Letras), Faculdade de Filosofia Letras e Ciências Humanas, USP, São Paulo: [s.n.], v. I. Historiografia, 2007.

SILVEIRA, Joel. Na Fogueira: Memórias. Rio de Janeiro: Mauad, 1998.

SIMIONI, A. P. C. Modernismo brasileiro: entre a consagração e a contestação, Perspective [En ligne], 2 | 2014.

SIQUEIRA, J. L. Modernismo Mineiro: sociabilidade e produção intelectual na década de 1920, dissertação de mestrado, Programa de Pós-graduação em História, Instituto de Ciências Humanas, Universidade Federal de Juiz de Fora, 2008. Disponível em: https://repositorio.ufjf.br/jspui/bitstream/ufjf/2822/1/jesanaliliansiqueira.pdf. Acesso em $18 / 01 / 2019$. 
SOARES, A. B. C. Academia dos Rebeldes: modernismo a moda baiana. 2006. 204 f. Dissertação (Mestrado em Literatura e Cultura) - Universidade Estadual de Feira de Santana, Feira de Santana, 2006.

SOUZA, J. Ralé Brasileira: Quem é e como Vive / Jessé Souza; colaboradores André Grillo [et al.]; Belo Horizonte: Editora UFMG, 2009.

STAMATTO, M. I. S. Um olhar na história: a mulher na escola (BRASIL: 1549 - 1910) - Programa de Pós-Graduação em Educação - UFRN; Anais do II Congresso Brasileiro de História da Educação; CBHE, pdf0539, Natal/RN; 2002.

TELLES, N. Escritoras, escritas, escrituras; in História das Mulheres no Brasil; Mary Del priori (org.); São Paulo, Contexto, 2000: 401 - 442.

TONI, F. C. Missão: as pesquisas folclóricas; Revista USP, São Paulo, n.77, p. 24-33, março/maio 2008.

VALENÇA, S. S. Tra-la-lá: vida e obra de Lamartine Babo / Suetônio Soares Valença. - 3. ed., rev. e ampliada. Rio de Janeiro: FUNARTE, 2014.

VELLOSO, M. Modernismo no Rio de Janeiro: turunas e quixotes. Rio de Janeiro: Fundação Getúlio Vargas, 1996.

ZANINI, W. A Arte no Brasil nas décadas de 1930-40, São Paulo: Edusp, 1991.PONTUAL, R. Dicionário das Artes Plásticas no Brasil; Editora Civilização Brasileira, 1969.

Bibliografia e referências bibliográficas dos perfis das personalidades citadas

ABEL SALAZAR

ARQUIVOS - Abel Salazar. Casa Comum. Disponivel em: <http://casacomum.org/cc/arquivos?set=e_2839>. Acesso em: 8 setembro 2018. 
MILHEIRAS, J. B. F. Abel Salazar: Uma Perspectiva Caleidoscópica. Dissertação (Mestrado em Letras). Departamento de Letras - Universidade da Beira; Covilhã; 2008

\section{ABELARDO ROMERO}

OLIVEIRA, A. Abelardo Romero: Um dos Primeiros Autores a Cativar do Modernismo em Sergipe. Disponível em: <http://literaturasergipana.blogspot.com/2013/08/abelardo-romero-um-dosprimeiros.html>. Acesso em: 19/09/2018.

\section{ABGUAR BASTOS DAMASCENO}

SOUSA, O. Q. D. Abguar Bastos e terra de Icamiaba, Romance da Amazônia: uma educação para a brasilidade. Campinas: Universidade Estadual de Campinas, Faculdade de Educação, tese (doutorado em educação), 2016.

PAIVA, M. A. C. Um outro herói modernista. Tempo soc., São Paulo, v. 20, n. 2, p. 175196, nov. 2008. Disponível em: <http://www.scielo.br/scielo.php?script=sci_arttext\&pid=S0103$20702008000200009 \& \operatorname{lng}=$ en\&nrm=iso>. Acesso em $12 \mathrm{dez} .2018$.

ABGUAR Bastos Damasceno. Dicionário Biográfico - FGV - CPDOC. Disponivel em: <http://www.fgv.br/cpdoc/acervo/dicionarios/verbete-biografico/abguar-bastos-damasceno>. Acesso em: 12 dez. 2018.

MOREIRA, F. F. O desejo de transformação em Casa na Duna, de Carlos de Oliveira; dissertação (mestrado em letras), PUC - Rio, 2010.

ADALGISA NERY

ADALGISA NERY. In: Wikipédia Disponível em https://pt.wikipedia.org/wiki/Adalgisa_Nery; Acesso em: 02/09/2018.

ADELAIDE ESTRADA

SILVA, C. S. Mulheres nas ruas do Porto; Revista Athena; Ed. 5; agosto 2018. Disponível em: <https://athena.pt/2017/08/21/mulheres-nas-ruas-do-porto-ii-cesar-santos-silva/\#more-715>. Acesso em: $31 / 08 / 2018$. 
VIDAL, F. C. M. et al. Os Escritos de Ademar Vidal e seu Papel na Construção, Preservação e Disseminação da Memória Cultural. Anais do XVII Encontro Nacional de Pesquisa em Ciência da Informação, UNESP, Marília, 2017.

ADOLFO CASAIS MONTEIRO

LEONE, C. Adolfo Casais Monteiro. Instituto Camões da cooperação e da Língua; Ministério dos Negócios Estrangeiros; Portugal, s/d. Disponível em <http://cvc.instituto-camoes.pt/seculoxx/adolfo-casais-monteiro.html\#.W4mpo-j0nIU>. Acesso em: 28/08/2018.

\section{ALFONSINA STORNI}

OLIVEIRA, K. R. Derrubando mitos: Alfonsina Storni e a reconstrução da identidade feminina no início do século XX. Dissertação (Mestrado em Letras), UFPE, 2009.

AFONSO SCHMIDT

ENCICLOPÉDIA Itaú Cultural de Arte e Cultura Brasileiras. Afonso Schmidt. Disponivel em: <http://enciclopedia.itaucultural.org.br/pessoa3128/afonso-schmidt>. Acesso em: 3 setembro 2018.

\section{ALFONSINA STORNI}

OLIVEIRA, K. R. Derrubando mitos: Alfonsina Storni e a reconstrução da identidade feminina no início do século XX. Dissertação de mestrado; Programa de Pós-Graduação em Letras; Universidade Federal de Pernambuco, 2009.

\section{ALFONSO HERNÁNDEZ CATÁ}

BUENO, S. Itinerário de Alfonso Hernandez Catá: (1885-1940); Revista Iberoamericana, Vol. LVI, Núm. 152-153, 1990.

ARAGÓN, U. Alfonso Hernández-Catá y los libros, Revista da Biblioteca Nacional de Cuba José Martí ano 106, no. 1, 2015. 
AMADO, J. Afonso Hernandez Catá;. Dom Casmurro, Rio de Janeiro, 06 abril 1939. 1 e 11.

\section{ALUÍZIO MEDEIROS}

BENEVIDES, A. E. Evolução da Poesia e do Romance Cearense, Imprensa Universitária/Universidade Federal do Ceará, Fortaleza: 1976, 10.

\section{ÁLVARO LINS}

ALVARO Lins. Academia Brasileira de Letras. Disponivel em: <http://www.academia.org.br/academicos/alvaro-lins>. Acesso em: 10 set. 2018; Álvaro Lins. Fundação Joaquim Nabuco. Disponível em: http://www.fundaj.gov.br/index.php?option=com_content\&view=article\&id=357>. Acesso em: 18 set. 2018.

\section{ÁLVARO MOREYRA}

ÁLVARO Moreyra. ENCICLOPÉDIA Itaú Cultural de Arte e Cultura Brasileiras, 2018. Disponivel em: <http://enciclopedia.itaucultural.org.br/pessoa2144/alvaro-moreyra〉. Acesso em: 19 set. 2018.

\section{ÁLVARO YUNQUE [ARISTIDES GANDOLFI HERRERO]}

ÁLVARO Yunque. Boedo un Barrio con Historias - 1a ed. - Buenos Aires: Gobierno de la Ciudad de Buenos Aires, $2006 . \quad$ Disponível em: $<$ http://www.buenosaires.gob.ar/areas/cultura/cpphc/archivos/libros/boedo.pdf $>$ Acesso em 09/09/2018;

BIOGRAFIA. Álvaro Yunque. Disponivel em: <http://www.alvaroyunque.com.ar/>. Acesso em: 09 Setembro 2018; PRENSA. Álvaro Yunque. Disponível em: <http://www.alvaroyunque.com.ar/prensa/alvaro-yunque-conferencia-ricardo-pasolini.html>. Acesso em: 09 Setembro 2018. 
NASSIF, L. Alzira Nogueira Reis, a primeira mulher a votar no país. Disponível em: <https://jornalggn.com.br/blog/luisnassif/alzira-nogueira-reis-a-primeira-mulher-a-votar-no-pais>. Acesso em 14/07/2018.

AMADEU AMARAL JUNIOR

OLIVEIRA, 2013; MONIZ, H. Amadeu Amaral Junior. In: Revista Carioca, Ed. 00483, 16.

AMADEU DE QUEIROZ

RICELI, M. Considerações sobre Amadeu de Queiroz. Disponível em <http://mhmtuanytoledo.blogspot.com/2011/05/era-uma-vez-amadeu-de-queiroz.html>. Acesso em: $19 / 09 / 2018$.

MACHADO, L. Amadeu de Queiroz. In Revista do Instituto Histórico e Geográfico de São Paulo; DUARTE, Nicolau e outros (org.); Vol. LXII; 1966

PEIXOTO, S. Entrevista com Amadeu de Queiroz. Vamos Lêr, Rio de Janeiro, 28 mar. 1940. 22 26.

GUIMARÃES, N. S. Relendo um romance de Amadeu de Queiroz: solidão e angústia em A Voz da Terra. Dissertação de Mestrado, Programa de Pós-graduação em Letras e Teoria Literária, Universidade Federal de Santa Catarina, 1992.

ANNA AMELIA CARNEIRO DE MENDONÇA

DUARTE, C. L. Anna Amélia: militância e paixão; Interdisciplinar, v. 3, n 3, Rio de Janeiro, 2007. ANTONIETTA DE SOUZA

SOUZA, A. Concerto de aniversário da A. B. M. e primeira conferência de sua série de 1933, Música, A Noite, Rio de Janeiro, 07/07/1933; A NOITE, Rio de Janeiro, 20/06/1933, 7. 
AMORIM, A. Tavares Bastos: o embaixador da poesia brasileira na França. Disponível em: <http://www.tertuliacapixaba.com.br/paraler/tavares_bastos_o_embaixador_da_poesia_brasileira_n a_franca.html>. Acesso em: 02/09/2018.

\section{ARLINDO DEL PICCHIA}

Sino Azul, Revista da Companhia Telefônica Brasileira, São Paulo, Janeiro de 1929, fevereiro de 1931, 1932, 1933 (na seção de aniversariantes do mês) e em fevereiro de 1953.

\section{ARTHUR RAMOS DE ARAÚJO PEREIRA}

GARCIA, R. A. G. Arthur Ramos e Durval Marcondes: Higiene Mental, Psicanálise e Medicina Aplicadas à Educação Nacional (1930-1950); Educ. Soc., Campinas, v. 35, nº 128, 629-996, jul.set, 2014.

GIRÃO, V. C. A coleção Arthur Ramos / (separata de Revista de Ciências Sociais, Fortaleza, v. 2, n. 1, 1971).

FAILlACE, V. (org,). Arquivo Arthur Ramos: inventário analítico; Rio de Janeiro, Edições Biblioteca Nacional, 2004.

\section{ATHOS DAMASCENO FERREIRA}

SILVA, G. C. Da Ficção à História: A Escrita da História de Athos Damasceno Ferreira (1940 1974), UFRS, $2012 . \quad$ Disponível em:<http://www.snh2011.anpuh.org/resources/anais/18/1344882953_ARQUIVO_Anpuhtextofinal. pdf>. Acesso em: 02/09/2018

\section{ATILIO EUGENIO GARCÍA MELLID}

Fuerza de Orientación Radical de la Joven Argentina. Wikipédia. Disponível em:<https://es.wikipedia.org/wiki/Fuerza_de_Orientaci\%C3\%B3n_Radical_de_la_Joven_Argentin a>. Acesso em: 03/09/2018. 
ADDISI, F. Atilio Garcia Mellid o el retorno de las montoneras. Noticias Congreso Nacional, 2018. Disponivel em: <https://www.ncn.com.ar/atilio-garcia-mellid-o-el-retorno-de-las-montoneraspor-federico-addisi/>. Acesso em: 03 setembro 2018.

\section{AUGUSTO RODRIGUES}

AlCOFORADO, M. O Outro Rodrigues. Memória Pernambucana, 2012. Disponivel em: <http://www.josenimeloadvogados.com.br/joomla/index.php?option=com_content\&view=article\&i $\mathrm{d}=39$ : o-outro-rodrigues-augusto-rodrigues \&catid=18:memoria-pernambucana $\&$ Itemid $=40>$. Acesso em: 9 out. 2018.

AYDANO DO COUTO FERRAZ

SAUDAÇÃO ao Povo Negro. Partido Comunista Brasileiro, 2009. Disponível em: <https://pcb.org.br/portal2/14/saudacao-ao-povo-negro/>. Acesso em: 10 out. 2018; SANTOS, G. O $\begin{array}{llll}\text { Jornalista Aydano } & \text { Couto } & \text { Ferraz. } & \text { Disponível }\end{array}$ em:<http://sergipeeducacaoecultura.blogspot.com/2010/11/o-jornalista-aydano-couto-ferraz.html> . Acesso em: 13/09/2018.

BARRETO DE ARAÚJO

ORLANDO M. Entrevista, CPDOC/FGV. Disponível em <http://www.fgv.br/cpdoc/acervo/historia-oral/entrevista-tematica/orlando-moscoso>. Acesso em: $01 / 10 / 2018$.

BENJAMIN LIMA

BENJAMIN Lima. Wikipédia. Disponível em <https://pt.wikipedia.org/wiki/Benjamin_Lima>. Acesso em: 03/09/2018.

\section{CARLOS DRUMMOND DE ANDRADE}

CARLOS Drummond de Andrade. Disponível em: <http://www.carlosdrummond.com.br/>. Acesso em: 01/09/2018; SIQUEIRA, 2008. 
LEMOS, M M. Candidatos da Oposição à Assembléia Nacional do Estado Novo (1945-1973): um Dicionário; Texto Editores; Lisboa; 2009; 111.

\section{CARLOS SCLIAR}

RAMOS, P. Ilustração e modernidade no campo artístico do Rio Grande do Sul na primeira metade do século XX: Debates e Rupturas. Anais do 22o Encontro Nacional Anpap. Belém: ANPAP/PPGARTES/ICA/UFPA. 2013. p. 2042 - 2056.

XAVIER, R. C. X. Uma Trajetória em Busca do Saber: Uma Referência na História das Idéias Lingüísticas no RS; Fragmentum, $\mathrm{n}^{\circ}$ 6. Laboratório Corpus: UFSM, 2004. Disponível em: <https://periodicos.ufsm.br/fragmentum/article/viewFile/6340/3837>. Acesso em: 05/09/2018.

\section{CARVALHO JUNIOR}

Revista Fon Fon, 15/02/1941, 20. Disponível na Hemeroteca Digital Brasileira; GIRÃO, R. A Academia de 1894, Academia Cearense de Letras, 1975 Disponível em <http://www.academiacearensedeletras.org.br/revista/Colecao_Antonio_Sales/ACL_1894_Raimun do_Girao/ACL_1984_Raimundo_Girao_108_JOAQUIM_MAXIMO_DE_CA>. Acesso em: $18 / 09 / 2018$.

\section{CELSO AUGUSTO}

CRONOLOGIA Ilustrada De Fortaleza - Acervo Abelardo Montenegro. Portal da História do Ceará. Disponivel em: <http://portal.ceara.pro.br/index.php?option=com_content\&view=category\&id=293\&Itemid=101>. Acesso em: 05 setembro 2018.

\section{CHARLES-LOUIS PHILIPPE}

CHARLES LOUIS PHILLIPE. In: Wikipédia. Disponível em: <https://en.wikipedia.org/wiki/Charles-Louis_Philippe>. Acesso em: 13/09/2018. 
COUTINHO, A; SOUSA, J. G, Enciclopédia de Literatura Brasileira. Rio de Janeiro: Fundação Biblioteca Nacional; Academia Brasileira de Letras, 2001. 2 v. ISBN 8526007238. Disponível em: <http://cleocampos.blogspot.com/2008/03/quem-clemenes-campos.html>. Acesso em: 13/09/2018; BOTELHO, 2014; OLIVEIRA, 2005.

DANILO BASTOS

AMARAL, M. A. Dercy de Cabo a Rabo, Editora Globo, 2011

DEOLINDO TAVARES

RAMOS, D. A. T. Potencialidades do Ensaio, Convergências Poéticas e Conceituais. Tese (Doutorado em Letras) - Faculdade de Filosofia, Letras e Ciências Humanas, Universidade de São Paulo. São Paulo, 46 - 53, 2015.

DIAS DA COSTA

SEIXAS, 2004; SANTOS, G. O contista Dias da Costa. Disponível em: <http://palavril.blogspot.com/2006/08/ensaio.html>. Acesso em: 15/09/2018.

DINIZ CUPERTINO

BIBLIOTECA - Acervo João Dinis Cupertino de Miranda. Fundação Cupertino de Miranda. Disponivel em: <https://www.cupertino.pt/biblioteca/acervos/>. Acesso em: 05 setembro 2018; NATALiNA Mora Pereira Bastos. Silêncios e Memórias. Disponivel em: <http://silenciosememorias.blogspot.com/2014_06_01_archive.html>. Acesso em: 5 setembro 2018.

EDISON CARNEIRO

ROSSI, L. G. F. O intelectual feiticeiro: Edison Carneiro e o campo de estudos das relações raciais no Brasil. Campinas, SP: Editora da Unicamp, 2015.

ARANTES, J. T. Edson Carneiro: o ogã comunista. Agência Fapesp. Disponível em: http://agencia.fapesp.br/edison-carneiro-o-oga-comunista/24087/. Acesso 28/10/2018. 
OLIVEIRA, Márcio de. A Participação Goiana na Construção de Brasília, Sociedade e Cultura, V. 8, N. 1, 2005, p.99.

EDGARD CAVALHEIRO

D’ONOFRIO, S. C. T. Fontes para uma biografia intelectual de Edgard Cavalheiro (1911-1958), Dissertação (Mestrado em Filosofia); Instituto de Estudos Brasileiros, USP, 2012.

ELIEZER BURLÁ

Memória Serafadi no Rio de Janeiro. Entrevista com Eliezer Burlá, 15/08/2004. Disponível em: https://vimeo.com/232179979. Acesso em 28/06/2018.

ELISA LISPECTOR

CAMPOS, F. C. O discurso melancólico em corpo a corpo, de Elisa Lispector. Dissertação (Mestrado em literatura brasileira), Faculdade de Literatura, UNB, 2006.

MASSON, J. A. Elisa Lispector - registros de um encontro. Dissertação (Mestrado em Literatura, Cultura e Contemporaneidade), Rio de Janeiro, Pontifícia Universidade Católica, 2008.

EMIL FARHAT

ABREU, A. e PAULA, C. Dicionário Histórico-Biográfico da Propaganda no Brasil. Editora FGV, Rio de Janeiro, 2007.

EMIL FILLA

KOCICHOVA, I. Dream of Freedom. Czech Interwar Artists and Classical Mythology. Studia Hercynia XX/1, 2016, 159-170. 
HOLMES, Henry. El hombre que no quiso ser rey, por Enrique Rodríguez Fabregat, Revista Ibero Americana, Vol. VIII, Núm. 16, novembro/1944.

Enrique Rodríguez Fabregat. In: Wikipédia. Disponível em: <https://es.wikipedia.org/wiki/Enrique_Rodr\%C3\%ADguez_Fabregat>. Acesso em: 04/09/2018.

ÉRICO VERÍSSIMO

ALVES, J. E. D. L. Érico Veríssimo: provinciano e universal. Canoas: Ulbra, 2006.

ERMELINDA LOPES VASCONCELOS

VOSNE, A. P. Visões do feminino, a medicina da mulher nos séculos XIX e XX; Editora Fiocruz; Rio de Janeiro; 2004.

FABIO CRISSIUMA

PINHEIRO, M. C. D. O. Perspectivas em Confronto no Campo da Educação: o Manifesto dos Pioneiros da Educação Nova (1932) e o Manifesto dos Inspetores de Ensino do Estado do Rio de Janeiro (1934). Germinal: Marxismo e Educação em Debate, Salvador, v. 7, n. 2 , 23 - 38, dezembro 2018.

\section{FABIO LEITE LOBO}

Engajado na luta pela democracia, durante o ano de 1937 foi colaborador do jornal literário Dom Casmurro. Neste período também atuou como tradutor tendo, entre outras obras, traduzido $A$ vida de Pasteur, de Renne Valery Radot (editora Vecchi, 1939) e Romain Rolland: sua vida, sua obra, de Stefan Zweig (edições Pongetti, 1937).

FERNANDO GÓES

OLIVEIRA, E. Quem é quem na negritude brasileira. São Paulo: Edição do autor, 1998, p.109. 
MAIO, M. C. Guerreiro Ramos Interpela a Unesco: Ciências Sociais, Militância e Antirracismo; Caderno C R H, Salvador, v. 28, n. 73, 77-89, Jan./Abr. 2015. http://www.scielo.br/pdf/ccrh/v28n73/0103-4979-ccrh-28-73-0077.pdf, Acesso em: 06/09/2018.

FERNANDO NAMORA

SACRAMENTO, M. Fernando Namora, Lisboa, Arcadia, 1967.

SILVA, P. J. M. Fernando Namora por entre os dedos da Pide: A repressão e os escritores no Estado Novo, Coimbra, Editorial Minerva, 2009.

RIBEIRO, R. Fernando Namora: Retalhos do artista enquanto médico-escritor. ípsilon, 2013. Disponivel em: <https://www.publico.pt/2013/08/09/jornal/retalhos-do-artista-enquantomedicoescritor-26934868>. Acesso em: 15 out. 2018.

FIRMINO MAGALHÃES

Diário Carioca, Ano 1939, Edição 00179. Hemeroteca Digital Brasileira.

FLAVIO DE CARVALHO

FLÁVIO de Carvalho. In: ENCICLOPÉDIA Itaú Cultural de Arte e Cultura Brasileiras. São Paulo: Itaú Cultural, 2018. Disponível em: <http://enciclopedia.itaucultural.org.br/pessoa9016/flavio-decarvalho>. Acesso em: 07 de Set. 2018;

MACHADO, V. S. Flávio de Carvalho. Disponível em: http://www.mac.usp.br/mac/templates/projetos/seculoxx/modulo2/modernidade/eixo/cam/artistas/ca rvalho.html. Acesso em: 07 de Set. 2018.

FRANS MASEREEL

BIOGRAFIE. Frans Masereel Stiftung. Disponivel em: <http://masereel.org/biographie/>. Acesso em: 10 setembro 2018. 
FRANS Masereel und seine Arbeiten für die Presse. Museum für Druckkunst Leipzig, 2016. Disponivel em: <https://www.druckkunst-museum.de/de/termin/frans-masereel-und-seine-arbeitenfuer-die-presse.html>. Acesso em: 8 set. 2018; ZWEIG, 1923.

FREDERICO DOS REYS COUTINHO

BOTTMANN, D. Bibliografia russa traduzida no Brasil (1900 - 1950); Revista de Literatura e Cultura Russa - RUS - USP; v.4 n.4; p. 58; 2014.

\section{GABRIELA MISTRAL}

LAGE, R. C. Vida e obra de Gabriela Mistral: uma ilustre desconhecida. Revista Alpha, n. 16, dez. 2015, 124-136.

VÁSQUEZ, C. G. S. Gabriela Mistral: das danças de roda de uma professora consulesa no Brasil. 2014. 187, Tese (doutorado) - Universidade Estadual de Campinas, Faculdade de Educação, Campinas, SP. Disponível em: <http://www.repositorio.unicamp.br/handle/REPOSIP/254008>. Acesso em: 27 ago. 2018.

GERALDO FERRAZ

HOFFMANN, A. M. P. Crítica de arte e bienais: as contribuições de Geraldo Ferraz. 2007. Tese (Doutorado em Artes Plásticas) - Escola de Comunicações e Artes, Universidade de São Paulo, São Paulo, 2007. doi:10.11606/T.27.2007.tde-05072009-193304. Acesso em: 2018-10-18.

\section{GILKA MACHADO}

GOTLIB, N. B. Gilka Machado. In. Textos críticos da Biblioteca Brasiliana Guita e José Mindlin. Disponível em <https://www.bbm.usp.br/node/78>. Acesso em 16/09/2018.

GRIECO, A. As poetisas do Segundo Parnasianismo. Evolução da poesia brasileira. $3^{\mathrm{a}}$ ed. rev. Rio de Janeiro, José Olympio, 1947, pp. 93-94.

BARRETO, L. Correspondência, ativa e passiva. Obras. São Paulo, Brasiliense, 1956. t.I, v. XVI, 230. 
GÓES, F. O pré-modernismo. Rio de Janeiro, Civilização Brasileira, 1974, pp. 259-266.

CAMPOS, H. Crítica. 2a ed. Rio de Janeiro/São Paulo/Porto Alegre, W. M. Jackson, 1945, 400.

GRACILIANO RAMOS

GRACILIANO Ramos. In: Enciclopédia Itaú Cultural de Arte e Cultura Brasileiras. São Paulo: Itaú Cultural, 2018. Disponível em: <http://enciclopedia.itaucultural.org.br/pessoa2658/graciliano-ramos>. Acesso em: 06 de Set. 2018.

MORAES, D. O Velho Graça: Uma Biografia de Graciliano Ramos; Boitempo Editorial; $1^{\text {a }}$. Ed.; 1992

HAMILCAR DE GARCIA

REGISTRO. Jornal do Brasil, Rio de Janeiro, 7 dez. 1991, 14.

NOTÍCIAS - Entrevista com o o tradutor de Darmapada, a principal obra do cânone budista. L\&PM

Editores, $2009 . \quad$ Disponivel em:

<https://www.lpm.com.br/site/default.asp?TroncoID=805133\&SecaoID=816261\&SubsecaoID=935

305\&Template=./artigosnoticias/user_exibir.asp\&ID=828126>. Acesso em: 06 out. 2018.

HEITOR LÚCIO DE OLIVEIRA E SILVA

CHARADISMO e Cruzadismo. O Malho, Rio de Janeiro, v. 127, 57, ago. 1950.

HELIO PEIXOTO

O Malho, Rio de Janeiro, 1930ไEdição 1434 (1). Hemeroteca Digital Brasileira.

HENRIQUETA LISBOA

PAIVA, K. B. Nos bastidores do arquivo literário: Henriqueta Lisboa entre versos e cartas. Tese

(Doutorado em Estudos Literários), Universidade Federal de Minas Gerais, UFMG, Belo Horizonte/MG, 2012. 
HENRIQUETA Lisboa, desbravadora de caminhos. Templo Cultural Delfos, 2018. Disponivel em: <http://www.elfikurten.com.br/2013/05/henriqueta-lisboa-desbravadora-de.html>. Acesso em: 12 out. 2018.

IBERÊ GOMES GROSSO

RABELO, P. C. M. The Cello and Piano works of Camargo Guarnieri. Tese de doutoramento em Artes musicais; Graduate School of The Ohio State University; 1996.

NABle, F; PRESGRAVE, F. Aspectos da Técnica do Violoncelo na Perspectiva de Márcio Carneiro; IV Mostra de Violoncelos de Natal; 2014.

IVA WEISBERG

LOPES, S. C. Um Sopro de Liberdade em Tempos de Autoritarismo: Iva Waisberg e o Debate Educacional dos Anos 1930-40; Anais Eletrônicos do IX Congresso Brasileiro de História da Educação; Universidade Federal da Paraíba; João Pessoa; 2017. Disponível em <http://www.ixcbhe.com/arquivos/anais/eixo2/individual/3504-3520.pdf>. Acesso em: 10/09/2018.

VIDAL, D. G. Anísio Teixeira, professor de professoras: um estudo sobre modelos de professor e práticas docentes (Rio de Janeiro, 1932-1935). Disponível em: <https://www.researchgate.net/publication/321285031_anisio_teixeira_professor_de_professoras_u m_estudo_sobre_modelos_de_professor_e_praticas_docentes_rio_de_janeiro_1932-1935>.Acesso em 22/02/2019.

IVANI RIBEIRO

RODRIGUES, C. Ivani Ribeiro, a Dama das Emoções; Novo Século, São Paulo; 2018.

RODRIGUES, O. História da Imprensa de Santos; edição do autor; 1979. Disponível em: <http://www.novomilenio.inf.br/santos/h0318z02.htm>. Acesso em: 11/09/2018.

JACQUES MADAULE

Vendredi (hebdomedaire), Wikipédia França. Disponível em: https://fr.wikipedia.org/wiki/Vendredi_(hebdomadaire). Acesso em 19/09/2018. 
Vendredi, Les Revues Literaires. disponível em: < http://www.revueslitteraires.com/articles.php?lng=fr\&pg=2209>. Acesso em 19/09/2018.

Emanuel Mounier, Wikipedia. Disponível em: 〈https://fr.wikipedia.org/wiki/Emmanuel_Mounier>. Acesso em 19/09/2018.

JARBAS ANDREA DE ARAÚJO COSTA

Paratodos, Ed. 0262, 4, 1928. Disponível em Hemeroteca Digital Brasileira. Acesso em 08/09/2018.

OBITUÁRIO. Jornal do Brasil, ed. 00283, 51, 1971. Disponível em Hemeroteca Digital Brasileira.

A Manhã, Rio de Janeiro, 1935; Hemeroteca Digital Brasileira, 2015. Acesso em: 26/09/2018; Novas Perspectivas para o Serviço Nacional de Teatro. Visões do Mundo, 1951. Disponível em: http://www.aldocalvet.org/aldo_calvet_SNT_noticiario_jornais_sobre_nomeacao_de_Calvet_Visoe s_Do_Mundo_03_1951.html, acesso em 07/09/2018.

\section{JEANETTE BUDIN}

SALES, G. G., Um Estudo sobre Metodologia da Linguagem (1949), de J.Budin. ANAIS do VI Congresso Brasileiro da História da Educação, 2011. Disponivel em: <http://alb.org.br/arquivomorto/edicoes_anteriores/anais17/txtcompletos/sem12/COLE_4130.pdf>. Acesso em: 09 set. 2018.

VIDAL, D. G. Anísio Teixeira, professor de professoras: um estudo sobre modelos de professor e práticas docentes (Rio de Janeiro, 1932-1935). Disponível em: <https://www.researchgate.net/publication/321285031_anisio_teixeira_professor_de_professoras_u m_estudo_sobre_modelos_de_professor_e_praticas_docentes_rio_de_janeiro_1932-1935>.Acesso em 22/02/2019.

JESUS LARA

TARICA, E. El Indigenismo de Jesús Lara: Entre El Campo y la Ciudad, Revista de Crítica Literaria Latinoamericana; ano XXXIV, no. 67. Lima-Hanover, 2008, Pp. 237-254. Disponível em $<$ https://as.tufts.edu/romancestudies/rcll/pdfs/67/TARICA.pdf>. Acesso em: 19/09/2018. 
MUNOZ, W. O. La Realidad Boliviana en la Narrativa de Jesus Lara; Revista Iberoamericana, Vol. LII, Núm. 134, Enero-Marzo 1986. Disponível em 〈https://revista-iberoamericana.pitt.edu/〉. Acesso em: 19/09/2018.

JOÃO ALBERTO

ANDRADE, 2009; DE Sol a Sol. Sol Nascente, Porto, 15 jul. 1937.Disponível em: <https://dspace.uevora.pt/ri/bitstream/123456789/310/14/Sol-N11_13.pdf>. Acesso em: 19/09/2018; Casa Museu Abel Salazar. Disponivel em: <https://cmas.up.pt/index.php?id=118>. Acesso em: 19 set. 2018; MILHEIRAS, 2008.

JOÃO AUGUSTO SEABRA DE MELO

MENEZES, O. Obra Reunida, Una, Natal, 2011.

COSTA, M. S. Produção em Revista: Representação do Moderno e do regional na experiência Potiguar, Tese (doutorado em Letras), Centro de Ciências Humanas e Letras da Universidade Federal do Rio Grande do Norte, 2008.

Feitiço, Rio de Janeiro, 01/07/1937. Hemeroteca Digital Brasileira.

Careta, Rio de Janeiro, 29/01/1949, 9. Hemeroteca Digital Brasileira.

RÊGO, M. A. A. Panorama cultural do Rio Grande do Norte, representações em periódicos do decênio de 1930. Imburana - revista do Núcleo Câmara Cascudo de Estudos Norte-RioGrandenses/UFRN. n. 5, fev./jun. 2012.

SERTÃO de Espinho e Flor - Algumas Notas. Mediocridade Plural, 2011. Disponivel em: <http://mediocridade-plural.blogspot.com/2011/06/algumas-notas-no-sertao-de-espinho-e-de.html> . Acesso em: 09 out. 2018.

JOÃO DE BARROS

MIRANDA, L. L. João de Barros e a Educação Luso-Brasileira nas Primeiras Décadas do Século XX; Anais do VIII Encontro de Pesquisa em Educação; Uberaba; 2015. 
ALMEIDA, C. D. L. João do Rio a Caminho da Atlântida: Por uma Aproximação LusoBrasileira. Tese (Doutorado em Letras), Pontifícia Universidade Católica do Rio de Janeiro, Rio de Janeiro, 2010.

JOÃO FALCO [IRENE LISBOA]

KADERKOVÁ, P. Irene Lisboa e a análise da sua obra Começa uma Vida; tese de mestrado; Departamento de Línguas e Literaturas Românicas; Universidade de Masaryk; Brno; 2007.

MORÃO, P. Irene Lisboa - Vida e escrita, Editorial Presença, Lisboa, 1989.

MORÃO, P. Irene Lisboa 1892 - 1958, Instituto da Biblioteca Nacional e do Livro, Lisboa, 1992.

MORÃO, P. O Essencial sobre Irene Lisboa, Imprensa Nacional, Casa de Moeda, Lisboa, 1985.

JOÃO PEREGRINO DA ROCHA FAGUNDES JUNIOR

NISKIER, A. Peregrino Júnior. Academia Brasileira de Letras, 2009. Disponivel em: <http://www.academia.org.br/publicacoes/peregrino-junior>. Acesso em: 12 dez. 2018.

JOAQUIM MACIEL FILHO

ÁVILA, J.S. Da Tradição na Província a sua Superação: A Crítica Literária nos Jornais de Alagoas. Tese (Doutorado em Letras), Faculdade de Letras - Universidade Federal de Alagoas, Maceió, 2009.

SILVA, S. A Roda de Maceió e o Projeto Regionalista: uma Perspectiva Etnográfica das Disputas ocorridas no Mundo do Livro dos anos 1930. In: Revista De Ciências Sociais, Fortaleza, v. $42, \quad$ n. $\quad 2, \quad$ jul/dez, 2011, $91 \quad-\quad 107 . \quad$ Disponível em<http://www.periodicos.ufc.br/revcienso/article/viewFile/435/417>. Acesso em: 20/09/2018.

JOAQUIM RIBEIRO

A Manhã, $14 / 06 / 1935, \quad 7 . \quad$ Disponível em <http://memoria.bn.br/DocReader/docreader.aspx ?bib=116408\&pasta=ano\%20193\&pesq=joaquim \%20ribeiro>. Acesso em: 25/09/2018; 
JOAQUIM Ribeiro e sua obra. Correio da Manhã, 27 maio 1959. Disponível http://memoria.bn.br/DocReader/Hotpage/HotpageBN.aspx?bib=089842_06\&pagfis=106324\&url= http://memoria.bn.br/docreader\#>. Acesso em: 25/09/2018.

RODRIGUES, 2013; O Folclore de Luto: morreu Joaquim Ribeiro, Correio do Ceará, Fortaleza, $1964 . \quad$ Disponível em: http://docvirt.com/docreader.net/DocReader.aspx $? \mathrm{bib}=$ tematico\&pagfis=2417. Acesso em: 23/09/2018.

JOEL SILVEIRA

CARVALHO, L. M. Cobras criadas: David Nasser e O Cruzeiro; SENAC, 2001.

Jornalistas Contam a História: O Estado Novo e o getulismo. Depoimento de Joel Silveira ao repórter Gilberto Negreiros. Almanaque Folha de S. Paulo, 9 de janeiro de 1979.

JORGE AMADO

AGUIAR, J. Jorge Amado: uma biografia. São Paulo: Todavia, 2018.

JORGE DE LIMA

BOSI, A. Jorge de Lima poeta em movimento (Do "menino impossível" ao Livro de sonetos). Estud. av., São Paulo, v. 30, n. 86, p. 183-207, Abril, 2016. Disponível em: $<$ http://www.scielo.br/scielo.php?script=sci_arttext\&pid=S0103$40142016000100183 \& \operatorname{lng}=\mathrm{en} \& n r m=\mathrm{iso}>$. Acesso em 06/02/2019.

JOSÉ ALVES RIBEIRO

SANTOS, G. O Rebelde Alves Ribeiro. Disponível em: <http://sergipeeducacaoecultura.blogspot.com/2010/11/o-rebelde-alves-ribeiro.html>. Acesso em: 05/09/2018. 
GARCIA, M. A. José Geraldo Vieira (1897-1977) Fortuna Crítica. Dissertação (Mestrado em Letras), Faculdade de Ciências e Letras de Assis - UNESP, Assis, 2003.

SANTOS, V. A. Nem Regional nem Nacional, mas Internacional: A Quadragésima Porta, Romance de José Geraldo Vieira, Revista Iberoamericana, Vol. LXXIV, n. 224, julho-setembro, $2008 . \quad$ Disponível em <https://revistaiberoamericana.pitt.edu/ojs/index.php/Iberoamericana/issue/view/195>. Acesso em: 25/09/2018.

JOSÉ LINS DO REGO

JOSÉ Lins do Rego. Academia Brasileira de Letras, 2016. Disponivel em: <http://www.academia.org.br/academicos/jose-lins-do-rego/biografia>. Acesso em: 19 out. 2018; Escritores e Livros - José Lins do Rego. In: Revista Fon Fon, 21/12/1938, 10; Está satisfeito com sua profissão de escritor? In: Gazeta de Notícias, 23/1/1938, p.7.

JOSÉ MARIA MONNER SANS

BUSTELO, N. Estudiantes, arielismo y socialismo científico: La revista porteña Ariel (1914-1915) como antecedente de los proyectos estudiantiles de la Reforma Universitaria. Centro de Historia Intelectual / UNQ CeDInCI / UNSAM, 2014.

CABALLERO, G. D.-C. LA CRÓNICA ARGENTINA DE RICARDO MONNER SANS. In: Temas Americanistas, Sevilha, v. 1, 1-22, 2013.

JOSÉ RÉGIO

VENTURA, A. As ideias políticas e a intervenção cívica de José Régio. Revista de História das Ideias, Coimbra, v. 16, 1994. Disponível em <https://digitalisdsp.uc.pt/jspui/handle/10316.2/41980>. Acesso em: 24/09/2018.

CAtTAPAN, J. C. R. José Régio na Presença: Arte Viva, Modernismo e Crítica. Boletim de Pesquisa NELIC, Florianópolis, v. 13, n. 20, 58-77, 2013. 
PINHAL, T. O Colecionismo em José Régio. Dissertação (Mestrado em Letras), Faculdade de Letras - Universidade do Porto, Porto, 2011.

JOSÉ SAMPAIO

OLIVEIRA, A. D. José Sampaio: “O Poeta dos Humildes”. Literatura Sergipana, 2014. Disponivel em: <http://literaturasergipana.blogspot.com/2014/03/jose-sampaio-o-poeta-dos-humildes.html>. Acesso em: 24 set. 2018.

SANTOS, G. A poesia de José Sampaio. Sergipe Educação e Cultura, 2010. Disponivel em: <http://sergipeeducacaoecultura.blogspot.com/2010/07/poesia-de-jose-sampaio.html>. Acesso em: 24 set. 2018.

GARCEZ, J. A. José Sampaio: poeta revolucionário. Revista da Academia Sergipana de Letras, Aracaju, n. 31, 137-139. 1975.

SAMPAIO, A. M. Em busca da manhã: a poesia de José Sampaio. São Paulo: Carthago Editorial, 1996.

SANTOS, S. S. José Augusto Garcez: Uma Trajetória no Campo Literário Sergipano (1938 1972). São Cristovão: Dissertação (Mestrado em História), Universidade Federal de Sergipe, 2018.

JUDAS ISGOROGOTA [AGNELO RODRIGUES DE MELO]

BARROS, F. R. A. de. ABC das Alagoas - Dicionário Biobibliográfico, Histórico e Geográfico de Alagoas, Brasília, 2005, Tomo I, 5, 115, 209; Tomo II, 40.

LEPIKSON, H. F. D. M. Judas Isgorogota. Disponível em: <https://judasisgorogota.webnode.com/>. Acesso em: 26 set. 2018.

JULIETA BÁRBARA

ANDRADE, Julieta Guerrine de. Julieta Bárbara: depoimento [jun. 1990]. São Paulo: MIS-SP, 1990. Entrevista concedida ao Projeto Centenário de Oswald de Andrade. Disponível em <http://acervo.mis-sp.org.br/audio/entrevista-de-julieta-barbara-guerrini-de-andrade-1>. Acesso em: 25/09/2018; 
Julieta é Bárbara. Direção: José Roberto Aguilar et al, 2016. Disponível em: <https://www.youtube.com/watch?v=D0WlhC4cPp8>. Acesso em: 25/09/2018.

\section{JULIETA CARRERA}

VALDÉS, N., Recordando a Julieta Carrera: el Feminismo Radical en Cuba. Cubainformación, 2008. Disponivel em: < http://www.cubainformacion.tv/index.php/genero/3621-recordando-ajulieta-carrera-el-feminismo-radical-cubano>. Acesso em: 26 set. 2018.

MIRANDA, C. M. Textos en Contexto. Discurso dialógico con los discursos sociales. Tese (Doutorado em Estudos Latinoamericanos), Universidad de Chile, Faculdad de Filosofia y Humanidades, 2010. Disponível em <http://www.tesis.uchile.cl/tesis/uchile/2010/fimontero_c/pdfAmont/fi-montero_c.pdf>. Acesso em: 26/09/2018

\section{KATHERINE MANSFIELD}

GONÇALVES, L. S. A (des)construção da noção de gênero nos contos de Katherine Mansfield. 2014. 190 f. Tese (doutorado) - Universidade Estadual Paulista Júlio de Mesquita Filho, Faculdade de Ciências e Letras de Assis, 2014. Disponível em: 〈http://hdl.handle.net/11449/124529>. Acesso em 12/10/2018.

MIZERKOWSKI, C. D. A Literatura Crítica e Confessional de Katherine Mansfield na gênese do romance em Nova Zelândia. Curitiba: Dissertação (mestrado em Estudos Literários). Faculdade de Letras, Universidade Federal do Paraná, 2008.

BRASIL, L. A voz epistolar de Katherine Mansfield. Instituto Moreira Salles. Disponivel em: $<$ https://www.correioims.com.br/uncategorized/a-voz-epistolar-de-katherine-mansfield-por-lyzabrasil/>. Acesso em: 8 set. 2018.

\section{KLIMENT IV. KOSTOV}

KOSTOV. Kliment Iv. Uma figura da poesia popular russa: Hristo Botjov. In: Esfera, Rio de Janeiro, n.3, 25, julho de 1938. 
CAPLOW, D. Leopoldo Méndez, Revolutionary Art, and the Mexican Print: in service of the people. Tese (doutorado em História da Arte), Universidade de Michingan; 1999. Disponível em $<$ https://digital.lib.washington.edu/researchworks/handle/1773/6230>. Acesso em: 08/09/2018.

\section{LÚCIA MIGUEL PEREIRA}

COUTINHO, F. S. Lucia: Uma biografia de Lucia Miguel Pereira; Brasília: Outubro edições, 2017.

PONTES, H. Crítica de Cultura no feminino. MANA 14(2): 511-541, 2008, 511 - 541. Disponível em http://www.scielo.br/pdf/mana/v14n2/a09v14n2. Acesso em 6/06/2019.

\section{LUCILO VAREJÃO}

FERRAZ, L. M. M. C. Os teatros de bairro no recife da década de 1930: efervescentes e fugazes, Anais do Encontro Internacional e XVIII Encontro de História da ANPUH, Rio de Janeiro, 2018.

\section{LUIS SOARES}

SILVEIRA, R. A. M. Mangue: uma ilustração da grande narrativa pós moderna; Dissertação (Mestrado em Letras); Departamento de Letras, PUC; Rio de Janeiro; 2002.

AMADO, J. Luis Soares e o colorido e o pitoresco do Nordeste. Dom Casmurro, 06/01/1940, 7. Hemeroteca Digital Brasileira.

\section{LYGIA DE AZEVEDO FAGUNDES}

PEREIRA, M. D. R. A. Um estudo da recepção crítica de Lígia Fagundes Telles. Anais do XII Seminário Nacional Mulher e Literatura e III Seminário Internacional Mulher e Literatura Gênero, Identidade e Hibridismo Cultural, Ilhéus, outubro 2007. Disponível em: $<$ http://www.uesc.br/seminariomulher/anais/PDF/MARIA\%20DO\%20ROS\%C3\%81RIO\%20ALV ES\%20PEREIRA.pdf>. Acesso em 20/10/2018. 
SouZA, M. D. G. E. O Futuro de Manuel Anselmo. Revista de Arte e Crítica de Viseu, 2006. Disponivel em: <http://aveazul.blogspot.com/2006/10/o-futuro-de-manuel-anselmo.html>. Acesso em: 26 set. 2018.

MATOS, L. S. D. A. Campanha de Imprensa contra o Bispo do Porto como Instrumento Político do Governo Português (setembro de 1958-outubro de 1959). Análise social, Lisboa, v. XXXIV, 29-90, $1999 . \quad$ Disponível em: <http://analisesocial.ics.ul.pt/documentos/1218798661E3kYO3uq3Cd57YB8.pdf>. Acesso em: $26 / 09 / 2018$.

DEPOIS da guerra o Brasil atingirá uma situação da maior importância no mundo: Entrevista com Manuel Anselmo. A Manhã, Rio de Janeiro, 4 outubro 1943. Disponível em: http://memoria.bn.br/pdf/116408/per116408_1942_00356.pdf> . Acesso em: 26/09/2018.

MANUEL DA FONSECA

CARMO, C. I. D. Manuel da Fonseca: a revolta com tinta de sol na noite de angústia. Jornal de Letras, Artes e Ideias, Lisboa, v. 1066, 12-13, 2013. Disponível em <https://sapientia.ualg.pt/handle/10400.1/5820>. Acesso em: 26/09/2018.

MARIA DA GLORIA RANGEL ALMEIDA PORTUGAL

MARIA da Gloria Rangel de Almeida Portugal. Geni. Disponível em: $<$ https://www.geni.com/people/Maria-da-Gl\%C3\%B3ria-AlmeidaPortugal/6000000068447802840>. Acesso em: 12 set. 2018.

OLHANDO o México. Vamos Ler, 11/04/1940, 40. Disponível em Hemeroteca Digital Brasileira.

CARVALHO, Jarbas. O que escrevem as mulheres, A Noite, 24/03/1940, 2.

UMA poetisa brasileira, Maria da Gloria de Almeida Portugal e seus versos. Correio da Manhã Suplemento Feminino, Rio de Janeiro, 14/05/1939, 1. 
ARRAES, J. O verdadeiro rosto de Maria Firmina dos Reis. Disponível em: http://jaridarraes.com/2017/05/12/o-verdadeiro-rosto-de-maria-firmina-dos-reis/. Acesso em 01/06/2019.

MARIA JACINTHA

RODRIGUES, M. A Presença de Maria Jacintha na Dramaturgia Brasileira do Século XX. Anais do Seminário Mulheres e Literatura. Ilhéus: ANPOLL (Associação Nacional de Pós-Graduação em Letras e Lingüística). 2007., $\quad 1 \quad$ - $\quad 11 . \quad$ Disponível em <http://www.uesc.br/seminariomulher/anais/sessoes.html>. Acesso em: 28/09/28.

RODRIGUES, M. Ressonâncias \& Memórias: Maria Jacintha, dramaturga brasileira do século XX - história de uma pesquisa. Niterói: 2006. 438 f. Tese (Doutorado em Letras, área de Literatura Comparada) - Instituto de Letras, Universidade Federal Fluminense, Niterói, 2006.

MARIA RAQUEL

COLABORADORES. SoL Nascente, 15 out. 1937. Disponível em <http://dspace.uevora.pt/ri/bitstream/123456789/316/14/Sol-N17_14.pdf>. Acesso em: 27/09/2018.

O Diabo, semanário de crítica literária e artística (1934 - 1940). Almanaque Republicano, 2012.Disponível em <http://arepublicano.blogspot.com/2012/06/o-diabo-semanario-de-criticaliteraria.html>. Acesso em: 28/09/2018.

MARIA VIOLETA COUTINHO

LOPES, S. C. e GURGEL, A. Trajetórias de professoras normalistas: A 'prata da casa' do Instituto de Educação do Rio de Janeiro (1930-1960). Rev. bras. hist. educ., Maringá-PR, v. 16, n. 4 (43), 241 271, out./dez. 2016. 
MÁRIO ANTÔNIO BARATA

BARATA, C. E. D. A. Memorial Mário Barata. Disponivel em: <http://mariobarata.blogspot.com/>. Acesso em: 18 out. 2018.

MÁRIO DE AZEVEDO

HORTENCIO, L; PORTO, H. M. A Primavera está sempre por perto. Disponível em: $<$ https://jornalggn.com.br/memoria/a-primavera-esta-sempre-por-perto/>. Acesso em 28//06/2018.

MARIO DIONÍSIO

DIONÍSIO, M. Autobiografia. O Jornal, Lisboa, v. coleção Autobiografias n. 3, 1987. Disponível em <http://www.centromariodionisio.org/autobiografia_mariodionisio.php>. Acesso em: 28/09/2018;

OliVEIRA, A. S. E. F., Mario Dionísio: A Vida. Casa da Achada - Centro Mário Dionísio. Disponivel em: <http://www.centromariodionisio.org/biografia_mariodionisio.php>. Acesso em: 27 set. 2018.

MARIO DONATO

ACERVO. Academia Paulista de Letras. Disponivel em: <http://www.academiapaulistadeletras.org.br/acervo.asp>. Acesso em: 28 setembro 2018.

DONATO, M. O meu Lobato. O Estado de São Paulo, Suplemento Literário, São Paulo, 18 abril 1982.

MÁRIO SETTE

FREYRE, G. O Escritor Mário Sette. O Cruzeiro, Rio de Janeiro, 26 agosto 1950, 10.

LIMA, H. Mario Sette. Diário de Notícias, Rio de Janeiro, 09 abril 1950, 2, quarta seção.

Mário Sette. Disponivel em: <http://www.mariosette.com.br/>. Acesso em: 28 set. 2018. 
MARIO SOUTO MAIOR

MAIOR, MÁRIO SOUTO. Depoimento de Mário Souto Maior, c. 2000. Disponivel em: <https://www.youtube.com/watch?v=m-JerJXY13k>. Acesso em: 29 set. 2018.

MARQUES REBELO [EDY DIAS DA CRUZ]

VIDAL, A. J. A ficção inacabada: uma leitura de Marques Rebelo. Tese (Doutorado em Teoria Literária e Literatura Comparada), Universidade de São Paulo, São Paulo, 1997.

SOUZA, R. L. A. O Rio de Janeiro do esquecido Marques Rebelo: uma tentativa de revisão. In: Anais do XV Encontro Regional de História - ANPUH. São Gonçalo: [s.n.], 2012. Disponível em: <http://www.encontro2012.rj.anpuh.org/resources/anais/15/1338061401_ARQUIVO_XVEncontro RegionalAnpuh-ORiodoesquecidoMarquesRebelo.pdf>. Acesso em: 30/09/2018.

REBELO, M. Oscarina; Editora Schmidt, Rio de Janeiro: 1931; Diretrizes, Ed. 004, julho/1938, 64.

MARQUES Rebelo. In: ENCICLOPÉDIA Itaú Cultural de Arte e Cultura Brasileiras. São Paulo: Itaú Cultural, 2018. Disponível em: 〈http://enciclopedia.itaucultural.org.br/pessoa2970/marques-rebelo〉. Acesso em: 30 de Set. 2018. Verbete da Enciclopédia.

ANTOLOGIA de Marques Rebelo. Revista Brasileira; Academia Brasileira de Letras, Rio de Janeiro, out/nov/dez 1974. 9 - 306.

\section{MAURA DE SENNA PEREIRA}

SCHROEDER, R. M. S. Uma mulher além de seu tempo: Maura de Senna Pereira. Dissertação (Mestrado em História) - Faculdade de História, Universidade Federal de Santa Catarina. Florianópolis. 1997.

BRAUN. Andressa. A Voz das Mulheres em Maura de Senna Pereira, a primeira jornalista catarinense. Comunicação - II Encontro Nacional da Rede Alfredo de Carvalho. Florianópolis, 2004.

KALCKMANN, Reginalda Eli. Maura em flor: uma fotobiografia. Dissertação (Mestrado em Letras) - Faculdade de Letras, Universidade Federal de Santa Catarina. Florianópolis. 2007. 
LIMA, A. A. Memórias Improvisadas. Diálogos com Medeiros Lima. Petrópolis: Vozes, 1973; I CONGRESSO da Juventude do Brasil. In. DICIONÁRIO Histórico Biográfico Brasileiro, CPDOC/FGV. Disponível em <http://www.fgv.br/cpdoc/acervo/dicionarios/verbetetematico/congresso-da-juventude-do-brasil-i>. Acesso em: 01/10/2018.

ATHAYDE, Tristão. O socrático e o pragmático. In: Jornal do Brasil, 10/06/1976,11.

MELO LIMA

Diretrizes, Notícias Literárias, Rio de Janeiro, 12/8/43, 18; Diretrizes, 29/10/1942, 16.

MIGUEL BUSTOS CERECEDO

Tiempos de odio / M. Bustos Cerecedo. Disponível em: <https://www.researchgate.net/publication/31770979_Tiempos_de_odio_M_Bustos_Cerecedo>. Acesso em: 01 out. 2018.

SANMARTín, J. Miguel Bustos Cerecedo. Centro de Estudios Filosoficos, Politicos y Sociales Vicente Lombardo Toledano, 2016. Disponivel em: <https://www.centrolombardo.edu.mx/miguelbustos-cerecedo-1912-1990/>. Acesso em: 01 out. 2018.

MIROEL SILVEIRA

MIROEL Silveira. Arquivo Miroel Silveira - ECA-USP, 2007. Disponivel em: <http://www2.eca.usp.br/ams/proj_t_ms.html>. Acesso em: 01 out. 2918.

MURILO MENDES

Diretrizes, setembro/1939, 113. 
Enciclopédia de literatura brasileira. Rio de Janeiro: Fundação Biblioteca Nacional; Academia Brasileira de Letras, 2001. 2 Apud NAIR Baptista Schoueri. Literatura Digital. Disponível em: $<$ https://literaturabrasileira.ufsc.br/autores/?id=11022>. Acesso em: 03/10/2018.

MAgalhães, C. M. O Desenho da História no Traço da Paisagem: Patrimônio Paisagístico e Jardins Históricos no Brasil. Tese (Doutorado em História); Universidade Estadual de Campinas; Campinas; 2015.

RIBEIRO, Robson Orzari. Revista do Patrimônio Histórico e Artístico Nacional: Textos de História da Arte engajados na política de preservação no Brasil; Dissertação (Mestrado em História da Arte); Universidade Estadual de Campinas; Campinas; 2013.

SILVA, C. M. C. Revista do Patrimônio: editor, autores e temas; Dissertação (Mestrado em História), Centro de Pesquisa e Documentação de História Contemporânea do Brasil - FGV, 2010.

BATISTA, N. Pintores do Rio de Janeiro Colonial. Revista do SPHAN, n. 3. Rio de Janeiro: MEC, 1939, 103-21.

GUTEMBERG, L. Retrato Inteiro da noiva de Prestes. In: Revista O Mundo Ilustrado, 23/04/1958, 10.

\section{NARCISA AMÁLIA}

FENSKE, E. K. (org.). Narcisa Amália de Campos - poeta, republicana, abolicionista e feminista do século XIX. Templo Cultural Delfos, junho/2015. Disponível em: http://www.elfikurten.com.br/2015/06/narcisa-amalia-de-campos.html. Acesso em: 29/10/2018.

NATALINA BASTOS

NATAlinA M. P. B. Silêncios e Memórias. Disponível em: <http://silenciosememorias.blogspot.com/2014_06_01_archive.html>. Acesso em: 05/09/2018. 
SERRALHEIRO, L. Mulheres em Grupo Contra a Corrente, Rio Tinto, Evolua Edições, 2011; NATALINA Mora Pereira Bastos. FEMINAE: Dicionário Contemporâneo. Comissão para a Cidadania e Igualdade de Género, Lisboa, 2013.

RANGEL, L. D. A. S. Lídia Besouchet e Newton Freitas: Mediações políticas e intelectuais entre o Brasil e o Rio da Prata (1938 - 1950). São Paulo: Tese (doutorado em História), FFLCH - USP, 2016.

NILO DA SILVEIRA WERNECK

NILO da Silveira Werneck. In: Boletim ABI, março/abril/ 1985, 12; NILO da Silveira Werneck. In: Jornal do Brasil, Obituário, Rio de Janeiro, 07/02/1985, $1^{\circ}$ caderno, 16.

ODILON NEGRÃO

MOREIRA, C. R. B. Ruínas de um tempo/templo ou sobrevivências de Dario Vellozo na literatura do presente. Florinaópolis; Tese (Doutorado em Literatura) Universidade Federal de Santa Catarina, 2011.

HUNZICKER, E. J. Poeta, Cronista, Escritor. Disponível em <http://curitibaeparanaemfotosantigas.blogspot.com/2018/06/odilon-negrao.html>. Acesso em: 04/10/2019.

OLGA PRAGUER COELHO

HORTENCIO, L. Olga Praguer Coelho, quase um século de intenso brilhar. Disponível em: <https://jornalggn.com.br/musica/olga-praguer-coelho-quase-um-seculo-de-excelente-musica/>. Acesso em 09/07/2018.

OMER MONT'ALEGRE

SOUZA, L. M. O Lugar Social do Autor no Rio de Janeiro na Década de 1930: Uma Leitura dos Discursos de Jorge Amado e Omer Mont'alegre na Revista Diretrizes em 1939. In: Anais do Encontro Nacional de História Política (GTHP/ANPUH). Porto Alegre: 2017. 
ONEYDA ALVARENGA

CAROZZE, V. M. A Menina boba e a discoteca. Dissertação (Mestrado em Filosofia). São Paulo: USP/ Instituto de Estudos Brasileiros, 2012.

BARONGENO, L. "Ainda sinto umas cócegas de explicar certas coisas" - Mário de Andrade, professor de Oneyda Alvarenga. Tese (doutorado em música). São Paulo: USP/ECA, 2014.

OSWALD DE ANDRADE

FONSECA, M. A. Oswald de Andrade: Biografia; Rio de Janeiro: Globo, 2007.

OSWALD DE ANDRADE FILHO

OSWALD de Andrade Filho. In: ENCICLOPÉDIA Itaú Cultural de Arte e Cultura Brasileiras. São Paulo: $\quad$ Itaú $\quad$ Cultural, $2018 . \quad$ Disponível em: <http://enciclopedia.itaucultural.org.br/pessoa10276/oswald-de-andrade-filho>. Acesso em: 22 de Out. 2018. Verbete da Enciclopédia.

OSWALDINO RIBEIRO MARQUES

COSTA, L. C. G. D. História da Literatura Brasiliense. Brasília: Thesaurus, 2005.

PAULO CAVALCANTI

CAVALCANTI, P. Da coluna Prestes à queda de Arraes: Memórias Políticas. Recife: Cepe Editora, 2015.

PAULO WERNECK

REZENDE, S. R. D. Paulo Werneck: A produção mural e a arquitetura moderna brasileira. São Paulo: Dissertação (Mestrado Interunidades em Estética e História da Arte) - Universidade de São Paulo, 2018. 
OBITUÁRIO, Jornal ABC, Domingo. Disponível em: <http://hemeroteca.abc.es/nav/Navigate.exe/hemeroteca/madrid/abc/2006/06/11/085.html>. Acesso em: 13/10/2018.

LEI n. 11.142, de 09/12/1991, DENOMINA Jornalista Paulo Zingg uma das vias públicas da capital paulista. Câmara Municipal de São Paulo; HECKER, Alexandre. Socialismo sociável: história da esquerda democrática em São Paulo (1945-1965); São Paulo: Fundação Editora da UNESP, 1998.

BUCCI, E. S. E. E. Antonio Candido: a militância por dever de consciência. Teoria e Debate, 1988. Disponivel em: <https://teoriaedebate.org.br/1988/03/01/a-militancia-por-dever-deconsciencia/>. Acesso em: 22 out. 2018.

PERCY LAU

PERCY LAU, Biografia. Disponível em: <https://www.percylau.com.br/sobre> Acesso em: $10 / 09 / 2018$.

PEREIRA DA SILVA

ACADEMIA BRASILEIRA DE LETRAS, Acadêmicos: Pereira Da Silva, A. J., última atualização 14/06/2017. Disponível em: http://www.academia.org.br/academicos/pereira-da-silva-j/biografia. Acesso em 22/03/2018.

\section{PHOCION SERPA}

PHÓCION Serpa. Casa de Oswaldo Cruz - Base Arch. Disponivel em: <http://basearch.coc.fiocruz.br/index.php/phocion-serpa>. Acesso em: 23 out. 2018.

RAYMUNDO MORAES

LARÊDO, S. Raymundo Moraes: na planície do esquecimento. Dissertação (Mestrado em Letras), Universidade Federal do Pará, Centro de Letras e Artes, Belém, 2007. 
PAIVA, M. A. C. D. Um paraíso selvagem: A Amazônia e os romances regionalistas de Raimundo Moraes. Tempo Social, revista de sociologia da USP, São Paulo, v. 28, n.2, 229 - 245, 2016.

GUIMARÃES, I. V. P. D. F. Na Planície Amazônica (1926): De "humilde oferenda intelectual da radiosa Amazônia" a experimento renovador da literatura regional. Florianópolis: In: Anais do XXVIII Simpósio Nacional de História, 2015.

REGINALDO GUIMARÃES

SOTERO, E. C. Representação Política Negra no Brasil Pós Estado Novo. São Paulo: Tese (Doutorado em Sociologia), Faculdade de Filosofia, Ciências e Letras, Universidade de São Paulo, 2015.

ROBERTO NOBRE

MATOS-CRUZ, J. Roberto Nobre, um homem de cinema. Museu do Traje. São Brás de Aportel. Disponível em <http://www.museu-sbras.com/nobre_cinema.htm>. Acesso em: 12/10/2018.

DUARTE, F. Apontamentos para uma biografia de Roberto Nobre, Celuloide, n²25, maio/1976, pp. 1-14.

ROSSINE CAMARGO GUARNIERI

BAYRÃO R. Da Semana de Arte Moderna aos Concretistas, Suplemento Literário do Jornal O Estado de São Paulo, 01/11/1969, 5.

RODRIGUES, L. As características da linguagem musical de Camargo Guarnieri. Revista Brasileira de Música, Rio de Janeiro, v. 28, n. 1, 107 - 140, jan / Jun 2015.

ROMERO, A. Rossine Camargo Guarnieri. Esfera de Letras, Artes e Ciências, Rio de Janeiro, n.6, 26, Out 1938.

NEGRÃO, O. Porto Inseguro: poemas de Rossine Camargo Guarnieri. Esfera de Letras, Artes e Ciências, Rio de Janeiro, n. 3, 34, Jul 1938. 
GOÉS, F. O Poeta Imigrou. Esfera de Letras, Artes e Ciências, Rio de Janeiro, n. 5, 57, Set 1938.

RUBEM BRAGA

DUBIELA, A. K. Rubem Braga nos anos 30: Um Coração ao Ar Livre. Estação Literária, Londrina, v. 11, 65 - 83, Julho 2013.

\section{SADY GARIBALDI}

SEPULTADO ontem Sady Garibaldi. In: Ultima Hora, 26/09/1959, 4; JORNALISTAS e Escritores prestam homenagem à memória de Sady Garibaldi. In: O Semanário, 19 a 25/12/1959, 9.

SANGIRARDI JUNIOR

SANGIRARDI Junior. In: DICIONÁRIO Histórico Biográfico da Propaganda no Brasil. Coordenadoras Alzira Alves de Abreu e Christiane Jalles de Paula, Rio de Janeiro: Editora FGV: ABP, 2007, 221.

SERAFIN JOSÉ GARCIA

SANMARTín, J. Arte, Poesía y Estudios Culturales: Biografías - Serafín J. García, 1905 - 1985.

Centro de Estudios Filosóficos, Políticos y Sociales Vicente Lombardo Toledano, 2018. Disponivel em: <https://www.centrolombardo.edu.mx/serafin-j-garcia-1905-1985/>. Acesso em: 23 out. 2018.

SERGIO SOARES

Sérgio Soares assina artigos na revista Vamos Lêr, Rio de Janeiro, década de 1930 - 1940.

SOUZA JUNIOR

CUNHA, L. F. D. De Souza Junior: um risco claro na vida da província. In: (ORG.), M. M. B. E. L. D. A., Os escritores que dirigiram a Biblioteca Pública do Estado do Rio Grande do Sul. Porto Alegre: EDIPUCRS/USF, 1999., 134. 
TELMO VERGARA

STEYER, F. A. "A Estrada Perdida" de Telmo Vergara. Porto Alegre: Tese (Doutorado em Literatura Brasileira), Instituto de Letras, Universidade Federal do Rio Grande do Sul, 2006.

THOMAZ MURAT

Revista da Semana, Livros Raros, Rio de Janeiro, 12/08/1939, 24.TOLEDO ARRUDA

TOMÁS SANTA ROSA

JUNQUEIRA, C. Biografia de Santa Rosa: Santa Rosa, um artista Plural. Funarte: Brasil, Memória das Artes. Disponivel em: <http://www.funarte.gov.br/brasilmemoriadasartes/acervo/cenario-efigurino/biografia-de-santa-rosa/>. Acesso em: 10 set. 2018.

RIBEIRO, J. A. P. R. Guignard e o ambiente artístico no Brasil nas décadas de 1930 e 1940; Dissertação (Mestrado em Artes Visuais), Escola de Comunicação e Artes - USP, 2009.

BUENO, L. Capas de Santa Rosa. São Paulo: Edições Sesc São Paulo e Ateliê Editorial, 2015.

CARDOSO, R. (org.). O design brasileiro antes do design: aspectos da história gráfica, 1870-1960. São Paulo: Cosac Naïfy, 2005.

TOMAZ KIM [pseudônimo de Joaquim Monteiro Grilo]

Fernando J. B. Tomaz Kim Um poeta de tempos dramáticos - Jornal de Letras, Artes e Ideias, Número 1172 - 2-15 Setembro de 2015.

VICENTE LEITE

GALVÃO, R. O convescote da modernidade. In: Regina Pamplona Fiúza (org.) /Academia Cearense de Letras. Modernismo - 80 anos. Fortaleza: Expressão Gráfica, 2002., 83 - 111.

WALDEMAR DE OLIVEIRA

FILHO, F.G.M.L. Os Nordestes e o Teatro Brasileiro. Tese (doutorado em Artes Cênicas), Universidade Federal da Bahia, 2017. Disponível em: 
https://repositorio.ufba.br/ri/bitstream/ri/23648/1/COPIA\%20COMPLETA.pdf. Acesso

em $7 / 11 / 2018$.

WALTER DA SILVEIRA

DIAS, J. R. Walter da Silveira: O eterno e o efêmero; Salvador; Oiti Editora, 2006.

WASHINGTON AZEVEDO

FELDMAN, S. Os anos 30 e a difusão do urbanismo americano no Brasil. Reseachgate.net, 2012. Disponivel em: <https://www.researchgate.net/publication/277842457_Os_anos_30_e_a_difusao_do_urbanismo_a mericano_no_Brasil>.Acesso em: 5 nov. 2018.

WILSON WOODROW RODRIGUES

FILHO, M. V. Marulheiro, viagem através de Aurélio Buarque de Holanda. 1a. ed. Maceió: Edufal, 2008.

LANTEUIL, H. D. Pai João, o novo poema do Brasil Velho. O Malho, Rio de Janeiro, 40, Setembro 1944. 


\section{ANEXO 1 - Currículo Sylvia de Leon Chalreo - Jornalismo}

(Transcrição de documento datilografado em rascunho, contendo rasuras, lacunas e anotações, respeitando a norma culta atual e a diagramação original).

Sylvia de Leon Chalreo

JORNALISTA PROFISSIONAL

CARTEIRA PROFISSIONAL - DEPARTAMENTO NACIONAL DE TRABALHO

$34.469-$ Série $29^{\mathrm{a}}$

$978.571-1938$

JORNALISTA PROFISSIONAL - REGISTRO

No. 2529 - Livro 7 - Folha 65 - 4 de Novembro de 1941

SINDICATO DOS JORNALISTAS PROFISSIONAIS DO RIO DE JANEIRO

Matrícula 18919 de 9 de Março de 1944

ASSOCIAÇÃO BRASILEIRA DA IMPRENSA

Sócia remida

ESFERA - 1938 - 1950 - Revista Mensal de Cultura - Rio de Janeiro - Redator chefe - Diretor responsável - Noticiarista - Crítico de Arte - Livros - etc. etc.

RIO SOCIAL - 1942 - 1944 - Redator chefe, repórter - crítico de arte - etc. etc. - Rio de Janeiro.

REVISTA RIO - 1944 - 1945 - Revista Mensal - Secretária - Reportagens - Crônicas - Modas Livros - Crítico de arte - Rio de Janeiro.

MOMENTO FEMININO - 1946 - 1949 - Jornal semanal - Secretária - Repórter - Crítico de Artes Plásticas - etc. etc. - Rio de Janeiro.

TRIBUNA POPULAR - 1947 - 1948 - Jornal Diário - Seção diária - A Mulher e seu Lar Reportagens - Rio de Janeiro. 
GAZETA DE NOTÍCIAS - 1949 - 1950 - jornal diário - Artes Plásticas - Rio de Janeiro.

ARTE - 1953 - Revista Mensal - Rio de Janeiro.

FORMA - 1954 - 1955 - Revista Mensal de Arte - Artes Plásticas - Teatro - Rio de Janeiro.

PARA TODOS - 1936 - 1958 - Jornal Mensal - Artes Pláticas - Rio de Janeiro

FON - FON - 1956 - 1958 - Revista semanal - Teatro - Reportagens - Crônica Social - Televisão - etc. etc. - Rio de Janeiro.

TRIBUNA DO POVO - 1958 - Jornal diário - crítica de arte diária - Rio de Janeiro.

O MÊS - 1958 - 1959 - Revista Mensal - Artes Plásticas - Teatro - Televisão - Reportagens Crítica Literária - Rio de Janeiro.

DIVULGAÇÃO PARANAENSE - 1958 - 1960 - Revista Mensal - Crônicas do Rio - Artes Plásticas Curitiba - Paraná.

O MOMENTO - 1959 - Jornal diário - Crônicas - Artes Plásticas - Niterói - Estado do Rio.

PORTUGAL EM FOCO - 1960 - Jornal semanal - Teatro - Artes Plásticas - Teatro - Televisão Rio de Janeiro.

JORNAL DAS MOÇAS - 1960 - 1961 - Revista semanal - Teatro - Artes Plásticas - Noticiário Rio de Janeiro.

RTV - REVISTA DA TELEVISÃO - 1960 - 1965 - Suplemento semanal do Diário de Notícias Telecrítica - Rio de Janeiro.

LUTA DEMOCRÁTICA - 1961 - Jornal diário - Suplemento dominical - Teatro - Artes Plásticas - Rio de Janeiro.

REVISTA DO FUNCIONÁRIO PÚBLICO - 1961 - Colaboração - Artes Plásticas - Rio de Janeiro. VIDA - 1961 - Revista semanal - Artes Plásticas - Teatro - Televisão - Rio de Janeiro.

TEATRO ILUSTRADO - 1961 - 1962 - Revista Mensal - Crônica Teatral - Teatro - Rio de Janeiro. 
AGÊNCIAS REUNIDAS - Notícias - Boletim mensal - Rio de Janeiro.

JORNAL DAS LETRAS - 1963 - 1973 - Jornal mensal - Artes plásticas - Rio de Janeiro.

\section{OUTRAS PUBLICAÇÕES}

O METROPOLITANO - Suplemento dominical - Artes Plásticas - Teatro - Rio de Janeiro.

TEMÁRIO - Revista - Rio de Janeiro.

LEIA - Revista - Rio de Janeiro.

BRASILIDADE - Revista - Rio de Janeiro.

LEITURA - Revista mensal - Rio de Janeiro. 


\section{ANEXO 2 - Currículo Sylvia de Leon Chalreo - Artes Plásticas}

\section{BIOGRAFIA - SILVIA //// SYLVIA DE LEON CHALREO}

Sylvia de Leon Chalreo nasceu a 11 de abril de 1905, no Morro do Barro Vermelho, em São Cristóvão, Rio de Janeiro. Formou-se professora pela Escola Normal do Distrito Federal / Rio de Janeiro / Bacharel em Direito pela Faculdade de Direito do Rio de Janeiro. Escritora, tradutora e jornalista profissional, teve nas letras o seu 'primeiro meio de expressão intelectual. Mais tarde dedicou-se à pintura, sua verdadeira vocação, em cujo exercício consolidou a fisionomia estática, particular e coerente, confirmando-se em Exposições Coletivas e Individuais pelo Brasil e no Estrangeiro como uma das expressões marcantes e significativas de nossas Artes Plásticas.

\section{EXPOSIÇÕES INDIVIDUAIS}

1. 1945 - LIVRARIA BRASILIENSE - Julho - São Paulo - SP.

2. 1946 - INSTITUTO DOS ARQUITETOS DO BRASIL - Janeiro - Rio de Janeiro - RJ.

3. 1952 - EXPOSICIÓN DE PINTURA GALERIA VELASQUEZ - Novembro - Buenos Aires - Argentina

4. 1955 - GALERIA OXUMARÉ - Dezembro - Salvador - BA.

5. 1956 - EXPOSIÇÃO DE PINTURA ESCOLA DRAMÁTICA MARTINS PENA - Abril / Maio - Prefeitura do Distrito Federal - Rio de Janeiro.

6. 1958 - EXPOSIÇÃO DE PINTURA GALERIA LEMAC - Novembro Dezembro - Recife - Pernambuco.

7. 1960 - GALERIA MACUNAÍMA - Maio - Diretório Acadêmico da Escola de Belas Artes - Rio de Janeiro.

8. GALERIA MUNICIPAL DE ARTE - Maio - Porto Alegre - RGS.

9. 1961 - MONTMARTRE JORGE - Julho - Copacabana - Rio de Janeiro.

10. 1963 - GALERIA DA CASA DO ARTISTA PLÁSTICO - Abril - São Paulo - SP.

11. 1963 - PINTURAS DE SILVIA - MUSEU DE ARTE DO PARANÁ - Biblioteca Pública Curitiba - Paraná.

12. 1964 - MONTMARTRE JORGE - Julho - Copacabana - Rio de Janeiro.

13. 1964 - GALERIA GUIGNARD - Setembro - Belo Horizonte - MG.

14. 1964 - GALERIA MUNICIPAL DE ARTE - Setembro - Universidade Federal de Viçosa Viçosa - MG. 
15. 1964 - GALERIA DE ARTE DO RECIFE - outubro - convite da Secretaria de Educação e Cultura - Recife - PE.

16. 1964 - GALERIA DE ARTE CASA DO ARTISTA PLÁSTICO - Novembro - São Paulo SP.

17. 1965 - CENTRO DE ARTE DE NOVA FRIBURGO - Janeiro - Praça Getúlio Vargas Nova Friburgo - RJ.

18. 1965 - SUDAMERICANA FIRST NEW YORK EXIBITION - Outubro - New York - USA.

19. 1966 - BRAZILIAN CENTER - New York - USA.

20. 1967 - COLUMBIA UNIVERSITY - New York - USA.

21. 1967 - LEME PALACE HOTEL - Julho - Rio de Janeiro.

22. 1968 - ATRIUM GALERIA - Maio - São Paulo - SP.

23. 1969 - BIOMBO - Dezembro - Rio de Janeiro.

24. 1972 - ARTE LIVRO - Junho - Belo Horizonte - MG.

25. 1973 - ELVASTON GALERY - Maio - Junho - Londres - Inglaterra.

26. 1973 - GRUPO B - Outubro - Rio de Janeiro.

27. (Rasurado)

28. (Rasurado)

29. (Rasurado)

30. (Rasurado)

31. 1979 - FUNDAÇÃO CULTURAL DO DISTRITO FEDERAL (Funarte - Caixa Econômica Federal) - Brasília - Galeria A - de 2 a 14 de outubro.

32. 1972 - Ministério das [...].

\section{EXPOSIÇÕES COLETIVAS}

SALÃO NACIONAL DE BELAS ARTES - DIVISÃO MODERNA - 1941 - 1950 (menos 1942) Rio de Janeiro

SALÃO DE MAIO - 1941 - 1942 - Rio de Janeiro

SALÃO FLUMINENSE DE BELAS ARTES - 1941 - 1953 - Instituto de Educação de Niterói Niterói - Estado do Rio 
FEIRA DE ARTE MODERNA - 1943 - Liga da Defesa Nacional - Campanha do Bônus da Guerra - ABI - Rio de Janeiro

EXPOSICIÓN DEL BRASIL EN CHILE - 1946 - Edifício da Cia Chilena de Navegación interoceânica - Valparaiso - Chile

EXPOSICIÓN DE PINTURA CONTEMPORÁNEA BRASILEÑA - 1946 - Universidad de Chile Santiago - Chile

SALÃO DE BELAS ARTES DO SAN - Sociedade de Artistas Nacionais - Salão Assyrio - Teatro Municipal - Rio de Janeiro

SALÃO DE PINTURA E ESCULTURA - 1949 - Auspícios do Ministério da Educação e Cultura Inauguração do Edifício da América Terrestres, Marítimos e Acidentes - Rio de Janeiro

SALÃO MUNICIPAL DE BELAS ARTES - 1949 - 1950 - 1954 - 1955 - Secretaria de Educação da Prefeitura - Rio de Janeiro

SALÃO DA ESCOLA DO POVO - 1950 - Diretório da ENBA - Rio de Janeiro

SALÃO DO ART CLUB DO RIO DE JANEIRO - 1950 - Enba - Rio de Janeiro

SALÃO NACIONAL DE ARTE MODERNA - 1952 - 1972 - Rio de Janeiro

SALÃO DA ASSOCIAÇÃO BRASILEIRA DE DESENHO - 1953 - ABD - Rio de Janeiro-RJ

GALERIA DEZON - 1953 - Rio de Janeiro

EXPOSIÇÃO DE 10 PINTORAS - 1954 - Galeria Dezon - Rio de Janeiro-RJ

SALÃO MINIATURA - 1955 - ABI - Rio de Janeiro

NOVO SALÃO CARIOCA - 1955 - Dep Municipal de Turismo - Rio de Janeiro

SALÃO DA REVISTA FORMA - 1956 - Galeria Dezon - Rio de Janeiro

SALÃO DE BELAS ARTES DE JUIZ DE FORA - 1956 - Juiz de Fora - MG

PEQUENO SALÃO DA EMBAIXADA FRANCESA MAISON DE FRANCE - 1957 - Rio de Janeiro

SALÃO DE BELAS ARTES DE JUIZ DE FORA - 1957 - Juiz de Fora - MG

BIENAL DO MÉXICO - 1958 - México

COLETIVA DE PRIMITIVOS - 1959 - Petite Galerie - Rio de Janeiro 
FESTIVAL DO RIO - 1960 - Cinelândia - Rio de Janeiro

SEMANA DE ARTE - 1962 - Pinacoteca de Juiz de Fora - Juiz de Fora

GALERIA DE ARTE BRASILEIRA - 1964 - São Paulo - SP

$19^{\circ}$ CONGRESSO INTERNACIONAL DE POSTAGENS AQUARELA DO BRASIL - 1965 - São Paulo-SP

CASAS GELLI - 1965 - Rio de Janeiro

PINTORES PRIMITIVOS - 1965 - Galeria Vernon - Rio de Janeiro

116º ANIVERSÁRIO DE JUIZ DE FORA - 1966 - Galeria de Arte Celina - Juiz de Fora-MG

PRIMITIVOS ACTUALES DA AMÉRICA INSTITUTO DE CULTURA HISPÂNICA - MadriEspanha

THE BRAZILIAN PRIMITIVE PAINTERS AND WOOD ENGRAVERS COPACABANA PALACE - 1967 - Rio de Janeiro-RJ

PINTORES BRASILEIROS - 1967 - Brazilian Center - Nova York-EUA

SEMAINE LATINO-AMERICAINE -1967 - Maison de la Amerique Latine - Paris-França

LEILÃO DE ARTE - 1968 - Lirismo Brasileiro - Salão da Secretaria de Estado de Informação e Turismo - Lisboa-PortugaTeatro Municipal do Rio de Janeiro - Rio de Janeiro

EXPOSIÇÃO COLETIVA DE PINTURA - 1968 - Museu Imperial de Petrópolis - Petrópolis - RJ EXPOSIÇÃO COLETIVA DE PINTURA - 1968 - Centro de Arte de Nova Friburgo - Nova Friburgo-RJ

EXPOSIÇÃO COLETIVA DE PINTURA - 1968 - Atrio DCT - Campos-RJ

TRÊS ASPECTOS DA PINTURA CONTEMPORÂNEA DEP CULTURAL DO ITAMARATY 1968 - Caracas-Bogotá-Costa Rica

THE BRAZILIAN CENTER OF NEW YORK AND ITS DIRECTORS PINTORES BRASILEIROS CONTEMPORÂNEOS - 1968 - Connecticut - USA

LIRISMO BRASILEIRO - 1968 - MIS - Rio de Janeiro-RJ

LIRISMO BRASILEIRO - 1968 - Salão da Secretaria de Estado de Informação e Turismo - LisboaPortugal

PAISAGEM HOJE - 1969 - Instituto Brasil EUA - Rio de Janeiro-RJ

LIRISMO BRASILEIRO - 1969 - Galeria Quixote - Madri-Espanha

BRAZILIAN PRIMITIVE PAINTERS - 1969 - Consulado Geral do Brasil - Nova York-EUA

LIRISMO BRASILEIRO - 1969 - Galeria Debret - Paris-França

PINTORES BRASILEIROS - 1970 - Artistas Ingênuos - Casino do Estoril Lisboa - Portugal 
NOVE PINTORES - 1970 - Club Campestre da Guanabara - Rio de Janeiro-RJ

ARTISTAS PRIMITIVOS - 1970 - Azulão Galeria - São Paulo-SP

CARNAVAL CARIOCA - 1970 - Instituto Brasil EUA - Rio de Janeiro-RJ

Artistas do Brasil para o Museu de Arte Contemporânea de Skoppe - 1971- Paço das Artes - São Paulo-SP

CINCO ARTISTAS CARIOCAS - 1971 - Departamento de Culturado Paraná - Curitiba-PR

II SALÃO DE ARTE HEBRAICA - 1972 - Sociedade de Arte Hebraica - Rio de Janeiro-RJ

EXPOSIÇÃO SOBRE A INFÂNCIA - 1972 - IAB - Rio de Janeiro-RJ

EXPOSIÇÃO DE ARTISTAS BRASILEIROS - 1972 - Museu da Faculdade Nacional de Arquitetura - Rio de Janeiro-RJ

EXPOSIÇÃO FULGURA SEIS - 1972 - Galeria G4 - Rio de Janeiro-RJ

EXPOSIÇÃO DE PRIMITIVOS CONTEMPORÂNEOS DO BRASIL E DO ESTRANGEIRO 1972 - Museu de Arte Brasileira - Faap - São Paulo-SP

EXPOSIÇÃO DE ARTISTAS INGÊNUOS - 1972 - Galeria San Marco Rio de Janeiro-RJ

PRIMEIRA COLETIVA - 1972 - Tora Ipanema - Rio de Janeiro-RJ

INAUGURAÇÃO DA PINACOTECA DA UNIVERSIDADE FEDERAL DE VIÇOSA - 1973 MG

COLETIVA NO INÍCIO DA TEMPORADA - 1974 - Galeria Artelivro Belo Horizonte-MG

LEILÃO CENA ABERTA - 1974 - Hotel Glória - Rio de Janeiro-RJ Mostra de Instinto e Criatividade Popular - Museu Nacional de Belas Artes - Rio de Janeiro-RJ

EXPOSIÇÃO DE MULHERES - 1975 - Hotel Intercontinental Rio de Janeiro-RJ

COLETIVA DE ARTISTAS DO RIO DE JANEIRO GALERIA DE ARTE DE VANGUARDA 1975 - São Paulo-SP

PINTORES NÄ̈F DO RIO - 1976 - Aliança Francesa - Santos-SP

MULHER - 1976 - Arte do Neoimpressionismo até Agora Palácio Pedro Ernesto - Rio de JaneiroRJ

INTERNATIONAL NAÏVE PAINTERS - 1976 - The Gallery White Rock Over Haddon - LondresInglaterra

BIBLIOTECA CÂMARA CASCUDO - 1977 - Natal-RN

EXPOSITORES DA ASSOCIAÇÃO INTERNACIONAL DE ARTES PLÁSTICAS - 1977 Santos-SP Primeiro Encontro Carioca de Pintura Ingênua Metrô Cinelândia - Rio de Janeiro-RJ

PRIMEIRA MOSTRA DE PINTORES PRIMITIVOS E INGÊNUOS MUSEU UNIVERSITÁRIO AUGUSTO MOTTA - 1978 - Rio de Janeiro-RJ 
SEGUNDO ENCONTRO CARIOCA DE PINTURA INGÊNUA - 1978 - Rio de Janeiro-RJ

\section{PRÊMIOS}

1943 - Menção honrosa - Salão Nacional de Belas Artes - Divisão Moderna, Rio de Janeiro/RJ 1947 - Medalha de bronze - Salão Nacional de Belas Artes - Divisão Moderna, Rio de Janeiro/RJ 1948 - Medalha de prata - Salão Nacional de Belas Artes - Divisão Moderna, Rio de Janeiro/RJ 1948 - Menção honrosa - Salão dos Artistas Nacionais 1949 - Menção com louvor - $1^{\circ}$ Salão Municipal de Belas Artes, Rio de Janeiro/RJ 1950 - Diploma de alto mérito $2^{\circ}$ Salão Municipal de Belas Artes, Rio de Janeiro/RJ 1950 - Medalha de prata - Salão de Caruaru/PE 1976 - MOÇÃO DE EFUSIVAS CONGRATULAÇÕES - Participação na exposição Mulher Arte do neoimpressionismo até agora - Aprovada pela Assembleia Legislativa do Estado do Rio de Janeiro - Autoria dos deputados Paulo Duque e Sandra Cavalcanti

\section{COMISSÕES}

1. DELEGADA BRASILEIRA NO $3^{\circ}$ CONGRESSO INTERNACIONAL DE CRÍTICOS DE ARTE - 1951 - Holanda

2. DELEGADA DOS ARTISTAS PLÁSTICOS NO $1^{\circ}$ CONGRESSO DE INTELECTUAIS - 1954 - Goiânia - Goiás

3. MEMBRO DO JÚRI DO SALÃO NACIONAL DE BELAS ARTES - DIVISÃO MODERNA Arte Decorativa - 1950 - Rio de Janeiro

4. MEMBRO DO JÚRI DO XXVI SALÃO FLUMINENSE DE BELAS ARTES - 1973 - Niterói Estado do Rio de Janeiro

5. JURI DE PREMIAÇÃO DO PRIMEIRO SALÃO DUQUECAXIENSE DE PINTURA - 1973 Caxias-RJ

6. MEMBRO DO JÚRI DE PREMIAÇÃO E SELEÇÃO DO SALÃO MELO NUNO - 1977 - MEC - Universidade Federal de Viçosa-MG

MUSEUS E PINACOTECAS 
1. PINACOTECA DA BIBLIOTECA MUNICIPAL DE SÃO PAULO - São Paulo (Fábrica de Vidros $)^{141}$

2. GALERIA DA ALDEIA - Arcozelo - RJ - Fundação Pinheiro Neto (Nossa Senhora dos Humildes)

3. MUSEU DE MANCHETE - Rio de Janeiro ${ }^{142}$

4. MUSEU DE ARTE HISPANO AMERICANA -Madri-Espanha (Cena Baiana)

5. MUSEU DE ARTE CONTEMPORÂNEA DO PARANÁ - Curitiba-PR (Cena de Rua)

6. MUSEU DE ARTE CONTEMPORÂNEA DE SKOPJE - Iugoslávia (Cena de Rua)

7. PINACOTECA MUNICIPAL PIMENTEL JUNIOR - Rio Claro/SP

8. MUSEU DA CIDADE DE CARUARU - Caruaru-PE - (Candomblé)

9. MUSEU DE CRATO DO CEARÁ - Crato-Ceará

10. UNIVERSIDADE DO ALASCA - ALASCA-USA - Velas das praias do Pina (Pernambuco)

11. PINACOTECA DA ASSOCIAÇÃO DOS EMPREGADOS DO COMÉRCIO - Rio de Janeiro (Cena da Campo)

12. MUSEU DE ARTE MODERNA DO RIO DE JANEIRO - Rio de Janeiro (Roda)

13. MUSEU DA BAHIA - Salvador - Bahia

14. MUSEU DE ARTE MODERNA DA BAHIA - Fundação Cultural da Bahia - Salvador/BA

15. Pinacoteca da Universidade de Viçosa - Viçosa-MG - GENTE EM CAMPO VERDE

16. PINACOTECA DA ESCOLA FEDERAL DE ARQUITETURA - Rio de Janeiro

17. MUSÉE D'ART NAÏF DE L'ILÊ DE FRANCE - Paris/França - Quem espera... e Cuidado com o andar...

18. Derbyshire Museum Services - Londres-Inglaterra - 5 serigrafias

19. MUAM - MUSEU UNIVERSITÁRIO AUGUSTO MOTA - Suan - Rio de Janeiro

20. FUNARTE - acervo - Rio de Janeiro

21. MUSEU NACIONAL DE BELAS ARTES - Rio de Janeiro - Marinha

22. MUSEU ANTÔNIO PARREIRAS - Niterói - Estado do Rio de Janeiro - Praia - Bahia

23. MUSEU DE ARTE NAÏF DE TREBNJE - Europa - Iugoslávia ${ }^{143}$

24. MUSÉE INTERNATIONAL D'ART NAÏF ANATOLE JAKOVSKY - Nice - França

\footnotetext{
${ }^{141}$ Atualmente Coleção de Arte da Cidade/ Centro Cultural São Paulo / SMC/ PMSP.

${ }^{142}$ No documento original, manuscrita ao lado deste item encontra-se a palavra "não".

${ }^{143}$ Atualmente o município pertence a Eslovênia.
} 


\section{BIBLIOGRAFIA}

1. ARTISTAS PINTORES DO BRASIL - Teodoro Braga - São Paulo-SP

2. Peintres Naïfs - Lexique de Peintres Naïfs du monde entier - Anatole Jakovsky $-1^{\mathrm{a}}$ Edição - França

3. ENCONTROS - Gilverto Cavalcanti - Maceió-Alagoas

4. DICIONÁRIO DAS ARTES PLÁSTICAS DO BRASIL - Roberto Pontual - São Paulo

5. LES PROVERBES VUE PAR LE PEINTRES NAÏFS - Anatole Jakovsky - Paris - França

6. PEINTRES NAÏFS - DICTIONNAIRE DES PEINTRES NAÏFS DU MONDE ENTIER -

7. GRANDE ENCICLOPÉDIA DELTA LAROUSSE - 12 volumes - reprodução de quadros em cores - Rio de Janeiro

8. DICIONÁRIO BRASILEIRO DE ARTES PLÁSTICAS - Instituto Nacional do Livro - MEC - Rio de Janeiro

9. ASPECTOS DA PINTURA PRIMITIVA BRASILEIRA - Flávio de Aquino - Spala Editora - Rio de Janeiro

10. O BRASIL POR SEUS ARTISTAS - Walmir Ayala - Edição do MEC

11. AS FESTAS BRASILEIRAS PELOS PINTORES POPULARES - Geraldo Edson de Andrade - Imprinta - Rio de Janeiro

12. ARTE PRIMITIVA-NAÏF BRASILIANA - Gianni Gelleni - Italia

A par de uma intensa atividade pictórica, de uma produção metódica e amadurecida, tem se dedicado à crítica de teatro, Teleteatro, artes plásticas e literatura, tem gasto intensamente sua vida na comprovação dos princípios humanos da fraternidade e esclarecimento do próximo, que tem sido as normas éticas de sua produção de Arte.

Walmir Ayala 
COLOUR FIESTA - 1979 - Brazilian Primitive Painters Art Gallery - Londres-Inglaterra

GALERIA OPUS - 1979 - Brasília-DF

GALERIA CRAVO E CANELA - 1979 - São Paulo-SP

MOSTRA, HAMILTONS FINE ART GALLERY - 1979 - Londres-Inglaterra

VI BIENAL INTERNACIONAL NAÏF - 1980 - Milão-Itália

GALERIA JEAN JACQUES - 1980 - Rio de Janeiro-RJ

GRANDE COLETIVA DE ARTE NAÏF GALERIA JACQUES ARDIES - 1980 - São Paulo-SP

10 ARTISTAS NAÏFS BRASILEIROS GALERIA JACQUES ARDIES - 1981 - São Paulo-SP

SEIS ARTISTAS NAÏFS BRASILEIROS GALERIA JEAN JACQUES - 1981 - Rio de Janeiro-RJ

GRANDE COLETIVA DE ARTE NAÏF BRASILEIRA GALERIA JACQUES ARDIES - 1981 São Paulo-SP

LE GENIE DES NAÏFS - 1982 - Grand Palais - Paris-França

ARTE NAÏF DO BRASIL - 1982 - Banco Sogeral - Porto Alegre-RS

BRÉSIL NAÏFS - 1986 - Espace Art 4 - La Défense - Paris-França

BRÉSIL NAÏFS - 1987 - Galerie Bad Rouah - Rabat-Marrocos

O MUNDO FASCINANTE DOS PINTORES NÄ̈FS - 1988 - Paço Imperial - Rio de Janeiro-RJ

PRESENÇA E POVO NA ARTE BRASILEIRA MUSEU DA CASA BRASILEIRA - 1990 - São Paulo-SP

TEATRO NACIONAL DE BRASÍLIA, Museu de Arte do Rio Grande do Sul, Galeria Ucbeu - 1990 - Rio de Janeiro-RJ

PINTURA, PRESENÇA E POVO NA ARTE BRASILEIRA - 1991 - Brazilian Art Collection FMI Visitor Center - Washington-EUA

HOMMAGE AUX MAÎTRES NAÏFS BRÉSILIENS MUSÉE D’ART NAÏF - 1999 - FigueirasEspanha

VI BIENAL NAÏF DO BRASIL - 2002 - SESC - Piracicaba-SP

ARTE NAÏF NO BRASIL - 2006 - Espaço Cultural Citigroup - São Paulo-SP

RARIDADES - 2006 - Galeria Jacques Ardies - São Paulo-SP

${ }^{144}$ Informações fornecidas no depoimento do galerista Jacques Ardies. 
RARIDADES - 2009 - Galeria Jacques Ardies - São Paulo-SP

O COLECIONADOR - 2012 - Arte Naïf Galeria Jacques Ardies - São Paulo-SP 